\title{
MINERALOGIA DE SOLOS DA REGIÃO SEMI-ÁRIDA DO ESTADO DO CEARÁ
}

\author{
FRANCISCO OCIAN BASTOS MOTA \\ Engenheiro Agrônomo
}

Orientador: Prof. Dr. JOÃO BERTOLDO DE OLIVEIRA

Tese apresentada à Escola Superior de Agricultura "Luiz de Queiroz", Universidade de São Paulo, para obtenção do título de Doutor em Agronomia, Área de Concentração: Solos e Nutrição de Plantas.

$$
\text { P I R A C I C A B A }
$$

Estado de São Paulo - Brasil

Setembro - 1997 
Dados Internacionais de Catalogação na Publicação (CIP) DIVISÃO DE BIBLIOTECA E DOCUMENTAÇĀO - Campus "Luiz de Queiroz"/USP

Mota, Francisco Ocian Bastos

Mineralogia de solos da regiáo semi-árida do estado do Ceará / Francisco Ocian Bastos Mota. - Piracicaba, 1997.

205 p. : il.

Tese (doutorado) - Escola Superior de Agricultura Luiz de Queiroz, 1997.

Bibliografia. Título

1. Ceará 2. Classificação 3. Floresta 4. Minefalogia 5. Região semi-árida l.

CDD 631.411 


\section{MINERALOGIA DE SOLOS DA REGIÃO SEMI-ÁRIDA DO ESTADO DO CEARÁ}

FRANCISCO OCIAN BASTOS MOTA

Aprovada em: 07.11. 1997

Comissão julgadora:

Prof. Dr. João Bertoldo de Oliveira

UNICAMP

Prof. Dr. José Luis Ioriatti Demattê

ESALQ/USP

Prof. Dr. Celso Augusto Clemente

ESALQ/USP

Prof. Dr. José Marques Júnior

FCAV/UNESP

Prof. Dr. Antônio Carlos Moniz

IAC

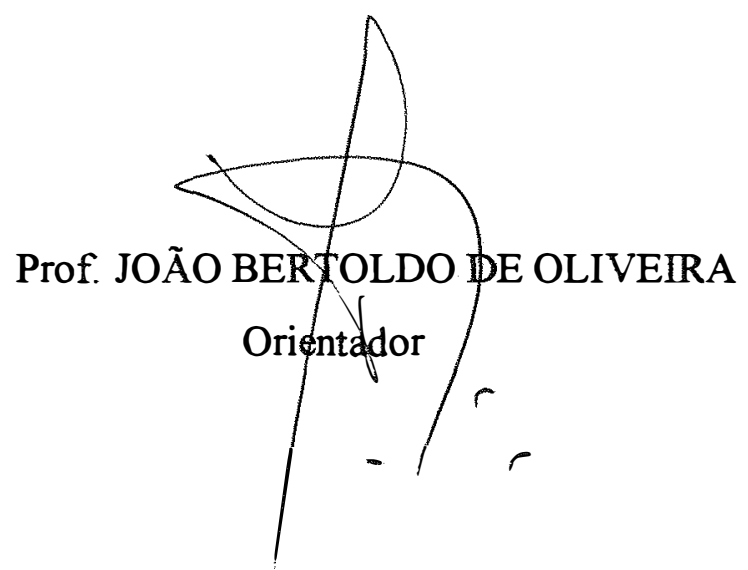


À Deus que me deu a vida

À minha querida esposa Alessandra e aos meus queridos filhos Rafael e Flávio pelo apoio, incentivo e compreensão durante a realização do curso 


\section{AGRADECIMENTOS}

O autor manifesta seus agradecimentos às seguintes pessoas e instituições:

Ao Prof. Dr. João Bertoldo de Oliveira pela confiança e orientação segura e amiga nas fases de execução deste trabalho.

Ao Prof. Dr. Harald Gebhardt da Universidade de OldenburgAlemanha, pela ajuda e colaboração na realização das análises mineralógicas e identificação e quantificação dos minerais.

Ao colega Miguel Cooper pela versão para o inglês do resumo.

Ao meu filho Rafael Perazzo Barbosa Mota pela sua valiosa ajuda na área de informática.

Aos colegas de curso: Fernando Cintra, Francisco Espírito Santo, Élcio, João Batista, Adeodato e Beliza, pelo convívio sadio e amigo durante o tempo de estadia em Piracicaba.

À Escola Superior de Agricultura "Luiz de Queiroz" e ao Curso de Pós-Graduação em Solos e Nutrição de Plantas, pelos ensinamentos ministrados.

À Universidade Federal do Ceará e ao Departamento de Ciência do Solo, pela oportunidade concedida para a realização do curso de doutorado.

Ao Conselho Nacional de Desenvolvimento Científico e Tecnológico $(\mathrm{CNPq})$, pela bolsa de estudos concedida.

A todos aqueles que direta ou indiretamente colaboraram conosco durante todas as etapas do curso de doutorado. 


\section{SUMÁRIO}

Página

RESUMO

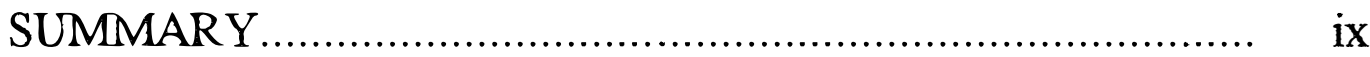

1 INTRODUÇÃO........................................................... 1

2 REVISÃO DE LITERATURA........................................... 4

2.1 Princípios gerais de intemperização de minerais e rochas...... 4

2.2 Características gerais e mineralogia................................. 16

2.2.1 Características gerais.............................................. 18

2.2.1.1 Podzólicos Vermelho-Amarelos - PVd e PVe................. 18

2.2.1.2 Brunos Não-Cálcicos - NC.......................................... 19

2.2.1.3 Planossolos Solódicos - PL......................................... 21

2.2.1.4 Solonetz Solodizado - S S.......................................... 22

2.2.1.5 Gênese do horizonte B textural.................................... 25

2.2.2 Mineralogia............................................................. 31

3 MATERIAL E MÉTODOS............................................. 39

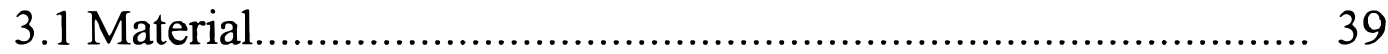

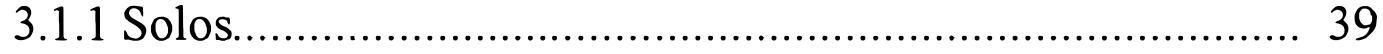

3.1.2 Descrição e características das áreas de estudo................... 39

3.1.2.1 Clima .............................................................. 42

3.1.2.2 Vegetação................................................................ 44

3.1.2.3 Geologia e material originário...................................... 45

3.1.2.4 Relevo e geomorfologia............................................ 46

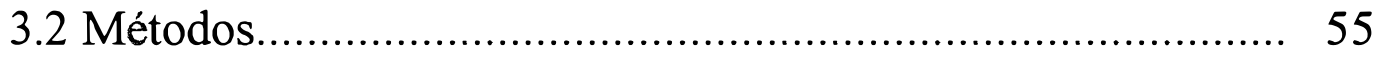

3.2.1 Coleta das amostras................................................... 55 
3.2.2 Preparo das amostras de solo............................................ 55

3.2.3 Métodos físicos de análise............................................. 56

3.2.4 Métodos químicos de análise............................................ 58

3.2.5 Análises mineralógicas..................................................... 60

4 RESULTADOS E DISCUSS ÃO............................................. 64

4.1 Atributos morfológicos, fisicos e químicos............................... 64

4.2 Mineralogia e transformações mineralógicas........................... 85

4.3 Interpretação dos resultados relacionados com a gênese, classi ficação e aptidão agrícola dos solos........................................ 160

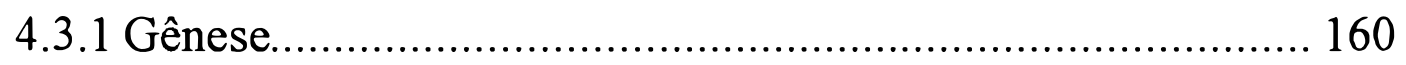

4.3.2 Classificação dos solos................................................... 169

4.3.3 Considerações sobre a aptidão agrícola dos solos................ 171

4.3.4 Considerações finais........................................................ 172

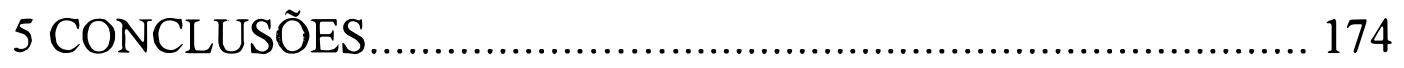

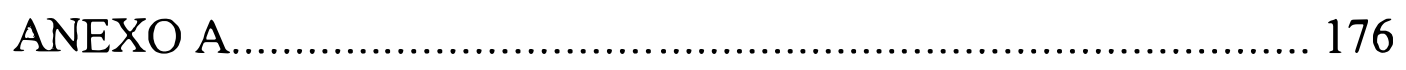

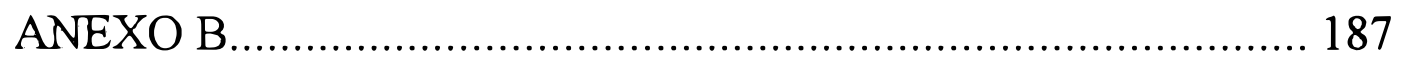

REFERÊNCIAS BIBLIOGRÁFICAS......................................... 191 


\title{
MINERALOGIA DE SOLOS DA REGIÃO SEMI-ÁRIDA DO ESTADO DO CEARÁ
}

\author{
Autor: FRANCISCO OCIAN BASTOS MOTA \\ Orientador: Prof. JOÃO BERTOLDO DE OLIVEIRA
}

\section{RESUMO}

Estudou-se os atributos mineralógicos, físicos químicos e morfológicos de onze perfis de solos do Estado do Ceará, com o objetivo principal de pesquisar os processos de intemperismo e as transformações mineralógicas que ocorrem nas frações areia, silte e argila de seus horizontes, tendo em vista a interpretação dos resultados nos aspectos de gênese, classificação e uso agrícola desses solos. A maioria dos solos está situada em região semi-árida (exceto os perfis 6 e 7 incluidos para estudos comparativos) e alinhados na paisagem em topossequências. Todos os pedons, excetuando-se o solo aluvial, apresentavam perfil completo e presença de horizonte B textural. A metodologia usada na pesquisa constou de descrições macromorfológicas de perfis, análises de rotina para os atributos físicos e químicos e análises mineralógicas. A mineralogia das frações areia e silte foi estudada por microscopia ótica de polarização e de contraste de fase e as das frações silte fino e argila por difração de raios X. As frações da maior parte dos solos foram ainda examinadas por microscopia eletrônica de varredura, para obtenção de informações 
complementares das alterações mineralógicas fornecidas pela microscopia ótica e difração de raios X. A avaliação semi-quantitativa dos minerais na fração argila foi feita com base na intensidade dos picos característicos de cada mineral, mediante o cálculo de suas áreas. De modo geral a areia e o silte dos pedons apresentaram quartzo, mica, plagioclásios, hornblenda e pseudomorfoses desses três últimos, cujas quantidades são variáveis nos vários perfis, em função da riqueza desses minerais primários na rocha subjacente ou saprolito desta. No silte fino, já foram perceptíveis a presença de minerais secundários. Na argila foram encontrados minerais tais como: caulinita, vermiculita, montmorilonita, interestratificado regular (vermiculita + mica), além de quartzo coloidal. A dominância de um desses minerais na fração argila nos pedons estudados, é muito dependente das condições de drenagem interna do solo e da composição mineralógica primária do material de origem. Assim, a biotita e a hornblenda dependendo da drenagem interna são transformadas inicialmente em caulinita, vermiculita ou montmorilonita. Os plagioclásios independente das condições de drenagem, sempre evoluem para uma caulinitização direta. A gênese do B textural, ou seja o enriquecimento em argila desse horizonte, aconteceu essencialmente "in situ", por meio de transformações dos minerais primários presentes no material originário proveniente da rocha local. A maioria dos perfis são pseudo-autóctones existindo porém alguns autóctones. A natureza pedimentar do horizonte $\mathrm{A}$ ou $\mathrm{A}+\mathrm{E}$, foi identificada com base em observações de campo (presença de linha de pedras) e também usando o quartzo como mineral índice e verificando a sua distribuição em função da profundidade na fração modal de cada horizonte. 


\title{
SOIL MINERALOGY OF THE SEMIARID REGION OF THE STATE OF CEARÁ
}

\author{
Author: FRANCISCO OCIAN BASTOS MOTA \\ Adviser:Prof. JOÃO BERTOLDO DE OLIVEIRA
}

\section{SUMMARY}

The mineralogical, physical, chemical and morphological attributes of eleven soil profiles of the state of Ceará were studied, with the main objective of studying the weathering processes and the mineralogical transformations that occur in the sand, silt and clay fractions of their horizons, having in mind the interpretation of the results in the aspects of genesis, classification and agricultural use of these soils. The majority of these soils are situated in the semiarid region (except profiles 6 and 7 included for comparative studies) and aligned in the landscape in toposequences. All the pedons, except aluvial soil, presented a complete profile and the presence of an argillic horizon. The methodology used in this research consisted of profile morphological descriptions, routine analysis for the chemical and physical attributes and mineralogical analysis. The mineralogy of the sand and silt was studied using a polarized optical microscope and phase contrast, and of the fine silt and clay by X-ray diffraction. The fractions of most of the soils were also examined using a scanning electron microscope, to obtain complementary information of the mineralogical alterations given by the optical microscopy and X-ray 
diffraction. The semi-quantitative analysis of the clay minerals was done, based on the intensity of the characteristic peaks of each mineral, calculating their areas. In general the sand and silt of the pedons presented quartz, mica, plagioclases, hornblende and pseudomorphs. The last three, whose quantities are variable in the various profiles due to the richness of these primary minerals in the parent material or saprolite. In the fine silt, the presence of secondary minerals was detected. In the clay fraction, minerals as kaolinite, vermiculite, montmorilonite, regular interstratified (vermiculite + mica), and colloidal quartz, were found. The dominance of one of these minerals in the clay fraction of the studied pedons, is highly dependent on the internal drainage conditions of the soil and of the primary mineralogical composition of the parent material. Thus, biotite and homblende, depending on the internal drainage, are transformed initially to kaolinite, vermiculite or montmorilonite. The plagioclases independent of the drainage conditions, always evolve to a direct kaolinization. The genesis of the argillic horizon, this means the enrichment in clay of this horizon, occurred essentially "in situ", by means of the transformation of primary minerals present in the local parent material. The majority of the profiles are pseudo-authoctonous existing however some authoctonous. The pedimental nature of the A horizon or $\mathrm{A}+\mathrm{E}$ horizons was identified based on the field observations ( presence of stone-lines) and also using quartz as an index mineral and verifying its distribution as a function of depth in the modal fraction in each horizon. 


\section{INTRODUÇÃO}

O solo é um elemento tridimensional e integrante da paisagem, resultante da ação conjunta e interdependente do clima, seres vivos, relevo, rocha matriz e tempo, denominados fatores pedogenéticos.

Da interação desses agentes, resulta para cada tipo de solo um perfil único e característico, cuja organização em horizontes e/ou camadas apresenta uma variabilidade de características e propriedades desde a superficie até a rocha matriz.

O conhecimento da mineralogia e das transformações mineralógicas que ocorrem nas diversas frações que compõe a terra fina dos horizontes de um perfil de solo, associado com a sua caracterização morfológica, fisica e química é de primordial importância para a compreensão da sua gênese, bem como para seu manejo, classificação e interpretação para fins agrícolas.

As condições de semi-aridez do Estado do Ceará, caracterizadas mais por distribuição irregular de chuvas do que por quantidade total de precipitação pluviométrica anual, diferente do que ocorre em outras condições semi-áridas do mundo, podem exercer influências consideráveis nas transformações mineralógicas de seus solos. Por outro lado os regimes de umidade ústicos e/ou ústicos transicionais para arídicos predominantes no 
Estado, podem também alterar a sequência de transformações mineralógicas e a gênese dos solos no mencionado ambiente.

Estudos mineralógicos realizados até o momento em solos do Estado são bastante escassos, restringindo-se praticamente àqueles contidos no Levantamento Exploratório-Reconhecimento de Solos do Estado do Ceará e inerentes apenas às frações mais grosseiras do solo.

A mineralogia, as transformações mineralógicas e a pedogênese no clima tropical semi-árido cearense carecem de muitos esclarecimentos, necessitando de pesquisas que possam elucidar tais processos. A gênese e as alterações dos minerais de argila e as transformações dos minerais primários em solos desenvolvidos de rochas cristalinas, poderão ser estudados e/ou esclarecidos através de estudos comparativos de ganhos e perdas entre os horizontes $\mathrm{C}$ e/ou $\mathrm{R}$ e o solum, por meio de análises qualitativas, quantitativas e/ou semi-quantitativas de difração de raios-X, microscopia ótica e microscopia eletrônica de varredura.

A gênese do horizonte B textural, do ponto de vista de enriquecimento e natureza da fração argila ainda é muito discutida, sendo dependente do clima, da drenagem interna do perfil, da posição no relevo e do material de origem do solo. Diferentemente do que ocorre em ambientes geológicos de natureza sedimentar, a formação do horizonte $\mathrm{Bt}$ em climas semi-áridos sob rochas Pré-Cambrianas, está mais predominantemente correlacionada às alterações dos minerais primários dessas rochas do que a processos de iluviação, ocasionando o aparecimento de perfis autóctones ou pseudoautóctones. Esses últimos são decorrentes dos processos geomorfológicos que modelaram a paisagem nas condições de semi-aridez, onde a presença 
de uma linha de pedras separando os horizontes A e/ou E do B, pode ser interpretada como decorrente de um material de origem pedimentar retrabalhado localmente. Por outro lado, a origem do $\mathrm{Bt}$ nátrico nas condições climáticas supra citadas, decorre da transformação de minerais primários ricos em sódio, associado com drenagem impedida e posição na paisagem.

Os solos Podzólicos Vermelho-Amarelos incluindo também os escuros (eutróficos e distróficos), os Brunos Não-Cálcicos os Planossolos Solódicos e os Solonetz Solodizados, objeto do trabalho em apreço, são de grande importância agronômica para o Estado do Ceará; seja pela expressão geográfica, seja pela necessidade de se conhecer com mais detalhe os atributos desses solos, tendo em vista um manejo mais racional dos mesmos.

Assim sendo, o presente trabalho face a importante expressão geográfica e agronômica dos solos mencionados, visa estudar à luz da metodologia empregada, a mineralogia de alguns perfis desses solos, com os seguintes objetivos específicos: a) caracterização morfológica, física e química; b) caracterização qualitativa, quantitativa e/ou semi-quantitativa da mineralogia das frações areia, silte e argila; c) estudos de processos de intemperismo e transformação de minerais nas mencionadas frações e d) interpretação dos resultados tendo em vista suas implicações na gênese e classificação dos solos. 


\section{REVISÃO DE LITERATURA}

A intemperização ou alteração de mimerais e rochas, sendo um processo que varia de um tipo para outro de rocha e/ou mineral, está na dependência de uma série de fatores intrínsecos e extrínsecos, inerentes a esses corpos naturais. Estudos de processos de intemperismo, transformações de minerais, caracterização mineralógica e gênese de solos, são bastante conhecidos na literatura especializada, embora na região Nordeste do Brasil, especialmente no Estado do Ceará, no polígono das secas, pesquisas dessa natureza em solos sejam raras.

$\mathrm{Na}$ presente revisão o assunto será subdividido em: 1) princípios gerais de intemperização de minerais e rochas e 2) características gerais gênese e mineralogia das classes de solos estudadas, nas quais serão enfatizados alguns aspectos de solos de regiões semi-áridas e/ou áridas.

\subsection{Princípios gerais de intemperização de minerais e rochas}

O intemperismo diz respeito à desagregação física e decomposição química de rochas, que não estão em equilíbrio sob as condições de temperatura, pressão e umidade na interface litosfera-atmosfera. Ele é um processo lento, gradual e contínuo, que ocorre durante o desenvolvimento do 
solo, até onde reações não possam mais ocorrer, atuando abaixo e dentro do "solum" (Buol et al. 1973).

Os minerais variam grandemente em sua estabilidade no ambiente do solo. Eles podem ser efêmeros ou serem suficientemente resistentes ao intemperismo. A velocidade que condiciona as suas alterações ou trans formações, é condicionada pela composição do material originário e fatores externos, tal como o clima (Allen \& Fanning, 1983). Várias séries de estabilidades para os minerais na zona do intemperismo têm sido propostas. Embora haja um acordo geral entre os vários autores, algumas diferenças aparecem na posição relativa de alguns minerais, que de acordo com Brewer (1964), decorre principalmente devido a diferenças em composição, tamanho e ambiente de intemperização.

A decomposição química, é um requisito fundamental para a formação do solo, incluindo a gênese dos minerais secundários. Ela compreende uma série de reações através das quais os minerais mudam sua estrutura e composição ou se dissolvem. A principal mudança ocorrida na alteração química, tanto de minerais primários como de secundários do solo, submetidos às condições de alteração superficial e sob drenagem livre se constituem de perdas de cations mono e bivalentes, perdas de sílica e acumulação de sesquióxidos.

Jackson \& Sherman (1953), distinguem dois tipos de intemperismo: geoquímico e pedoquímico. $\mathrm{O}$ intemperismo geoquímico acontece abaixo do solum (horizonte $\mathrm{C}$ ), enquanto que o pedoquímico é a desagregação e decomposição de minerais dentro dos horizontes $\mathrm{A}$ e $\mathrm{B}$, associado com todos os processos biológicos e outros de formação do solo. 
A alteração química das rochas é dependente de fatores intrínsecos e extrínsecos, cada qual desempenhando um papel de importância. O efeito final é determinado pela soma integrada de todos os fatores. Entre os fatores intrínsecos destacam-se: a natureza ou susceptibilidade das rochas e seus minerais às ações químicas, o tamanho dos minerais, a natureza da superfície e outros. Com relação aos extrínsecos, se incluem o clima com todos os seus componentes, a drenagem, as ações bióticas e o tempo. Também podem ser agregados nessa relação os fatores modificantes, como o relevo e a posição topográfica. A expressão desses fatores acontece através das reações ou agentes do intemperismo químico tais como: hidratação, solução, hidrólise, carbonatação, acidificação etc. (Besoain, 1985).

Goldich (1938), estabeleceu uma série de estabilidade dos minerais presentes nas frações areia e silte dos solos frente à meteorização. Ela é semelhante à da ordem de cristalização dos minerais das rochas magmáticas, denominada série de reação de Bowen. Através de estudos detalhados com as rochas granito, diabásio e anfibolito, Goldich concluiu que os minerais máficos são menos estáveis que os félsicos e que os primeiros minerais a se formarem pela consolidação do magma são os menos estáveis. Desse modo as olivinas e o quartzo são os minerais de menor e maior estabilidade, ocorrendo uma gradação contínua de estabilidade entre esses dois extremos.

Os minerais formados por cadeia simples (piroxênios) se alteram mais facilmente do que os de cadeia dupla (anfibólios). A diferença não pode ser explicada considerando-se apenas a estrutura, já que ambos são inossilicatos. A relação cátions bivalentes/silício de 1:1 nos piroxênios e de 7:8 nos anfibólios, parece ser o fator responsável (Marshall, 1964). 
No grupo dos filossilicatos (micas), as duas espécies mais comuns são a biotita e a muscovita. De acordo com Moniz et al. (1975), a biotita se altera mais rapidamente do que a muscovita e as razões principais são: a) presença do ferro ferroso, que se oxida facilmente em ferro férrico, afetando a neutralidade elétrica da estrutura; b) presença do magnésio que expõe a camada de octaedros a um maior ataque por parte das soluções ácidas. Em regiões tropicais, devido o maior rigor do intemperismo, os produtos iniciais da decomposição da mica não são os principais. A vermiculita ocorre com frequência, mas seus teores são muito baixos e a montmorilonita tem ocorrência escassa. O produto principal da decomposição da mica é a caulinita, que vem a ser o estágio mais importante de sua decomposição (Moniz et al. 1975).

Jackson et al. (1948), divulgaram seus estudos sobre uma sequência de meteorização dos minerais da fração argila em solos e sedimentos. $\mathrm{Na}$ sequência os autores consideram que a presença de certos minerais pode ser usada como indicadora da intensidade de intemperização a que esteve submetido um determinado solo. Foram propostos treze estágios de alteração ordenando-se os minerais de acordo com sua resistência crescente. A sequência de Jackson é muito importante pois permite conhecer qual o estágio de alteração que tem um solo ou sedimento, porém não é indicativa de como os minerais secundários se relacionam com os primários dos quais se originaram. As seguintes generalizações são apresentadas com relação a sequência de meteorização: a) a fração argila do solo é formada de 3 a 5 minerais, existem no entanto 1 ou 2 predominantes; b) a medida que diminui a quantidade dos minerais dos primeiros estágios, aumenta o teor daqueles 
dos estágios seguintes; c) o intemperismo aumenta de baixo para a superfície do solo, ou seja, quanto mais próximo da rocha, maior o percentual de minerais de argila menos intemperizados ou de grade $2: 1$.

Os minerais mais frequentes na fração argila dos solos tropicais aparecem nos últimos quatro estágios. A caulinita (estágio 10), vem logo depois da montmorilonita (estágio 9), o que explica sua ocasional presença ao lado daqueles dos últimos estágios (Moniz \& Jackson, 1967).

Os fatores ambientais tais como o clima e seus componentes, a drenagem e os fatores bióticos, todos eles intimamente relacionados, têm influência decisiva na formação dos minerais de argila do solo. Assim, não é muito frequente encontrar caulinita em solos de regiões áridas muito quentes (Besoain, 1985).

Buol et al. (1973), consideram que as condições mais favoráveis à formação de caulinita no solo ocorrem sob condições de aproximadamente igual concentração de Si e Al, alta concentração hidrogeniônica, drenagem livre e essencialmente carência de magnésio e outras bases. A montmorilonita por sua vez se forma sob um ambiente de alta concentração de sílica e magnésio. Essas condições são encontradas, quando da decomposição de minerais silicatados primários ricos em $\mathrm{Mg}$ e $\mathrm{Fe}$ e o alto potencial de sílica é mantido por um lento movimento ou estagnação da água no solo (drenagem impedida e/ou imperfeita). Goetita e hematita são sintetizadas a partir da decomposição de minerais ferro-magnesianos sob condições de alto potencial positivo de oxi-redução e moderado a alto $\mathrm{pH}$.

A formação de minerais de argila a partir de hormblendas (grupo dos anfibólios) depende das condições de drenagem e precipitação. A tendência 
geral é a formação de montmorilonita ou clorita nas primeiras etapas. As cadeias silicatadas formam lâminas bidimensionais sobre as quais se incorporam íons de alumínio e magnésio formando-se montmorilonita ou clorita. $\mathrm{O}$ ferro se oxida para goetita ou hematita e o titânio origina anatásio. Com o aumento da intensidade da meteorização, ocorrem perdas de elementos alcalinos terrosos e sílica, formando-se caulinita e enriquecendose o meio em óxidos de ferro e titânio (Besoain, 1985).

A eliminação de $\mathrm{K}$ das micas durante a pedogênese, a introdução de outros íons como $\mathrm{Mg}$ ou $\mathrm{Al}$ e outras trocas, determinam a formação de vários minerais de argila ( vermiculita, clorita, ilita, montmorilonita, caulinita ), a partir desses minerais, com a sequência e alteração sendo influenciada pelas condições ambientais. Mac Ewan (1948), comprovou a formação de montmorilonita trioctaédrica a partir da biotita e Wilson (1966), a formação de vermiculita a partir de um gabro rico em biotita e quartzo. Ojanuga (1973), estudou a decomposição da biotita sob clima tropical úmido, $\mathrm{pH} 4,9$ a 5,2 e boa drenagem e verificou que a biotita se transformava diretamente em caulinita.

Demattê et al. (1991), verificaram a evolução do intemperismo numa sequência de solos desenvolvidos de diabásio e influenciados pela drenagem em Piracicaba-SP, e concluiram que a drenagem do solo afetou a intensidade de ganhos e perdas de elementos no processo de intemperismo, ocorrendo de maneira geral perdas mais intensas nos locais mais bem drenados. Isso implica, que caso não haja um enriquecimento contínuo de elementos de uma fonte externa, os sistemas estão evoluindo para um sistema residual de intemperismo. Demattê \& Marconi (1991), também concluiram que uma 
maior concentração de montmorilonita ocorre nos solos de drenagem imperfeita, apesar da região ser subtropical semi-úmida. Em um solo pobremente drenado, quando comparado a um bem drenado, a lixiviação e a velocidade de meteorização são reduzidas, explicando seus maiores teores de silte, bases trocáveis, minerais de argila 2:1 e maior CTC (Demattê et al. 1992). Garci et al. (1988), investigaram a alteração de minerais na fração areia de dez perfis de solos de uma zona semi-árida com problemas de drenagem. Verificaram que o mais importante efeito do clima do solo, ocorre sobre o intemperismo químico dos minerais, influenciando principalmente as suas transformações. A meteorização da biotita sob condições temperadas, tropicais e equatoriais foi estudada por Novikoff et al. (1972), onde dois meios de evolução do mineral foram observados. No primeiro caso há uma transformação para caulinita com um estágio de vermiculita mais ou menos efêmero. Essa alteração ocorre em locais bem drenados em regiões tropicais úmidas. Sob drenagem excessiva, o produto final da biotita pode ser gibbsita; em climas frios e úmidos o estágio intermediário de vermiculita é prolongado. No segundo modo de evolução, há transformação da biotita para montmorilonita. Essa transformação, uma feição de climas mais secos, ocorre somente em ambientes mais ricos em sílica e com drenagem pobre.

A síntese de argilas a partir de rochas básicas é mais pronunciada do que a partir de rochas ácidas. A caulinita como um produto de alteração é produzida em pequenas a moderadas quantidades a partir de rochas ácidas. A formação da ilita também não é comum e parece está condicionada a uma prévia sericitização de feldspatos. Esmectitas expansivas ou cloritasesmectitas parcialmente expansivas, constituem os produtos mais comuns 
formados a partir de rochas ígneas sob condições áridas ou semi-áridas no sudeste de Israel (Singer, 1984). Estudos químicos e mineralógicos foram conduzidos em materiais meteorizados de seis perfis de solos derivados de granito em vários locais do Brasil. Quartzo e feldspato potássico foram os minerais primários mais abundantes e a caulinita o secundário principal, sendo principalmente produto de alteração do feldspato. Em ambiente semiárido a desagregação da mica está associada com a formação de esmectita. Tais estudos tiveram como conclusão principal o fato de que os fatores que controlam a lixiviação profunda são complexos e a noção comum de que a velocidade de intemperismo é maior nas baixas latitudes deve ser repensada (Melfi et al. 1983).

As transformações mineralógicas durante o intemperismo do saprolito para o solum formados a partir de biotita-gnaisse, biotita-muscovita-gnaisse, biotita-muscovita-hornblenda-gnaisse e biotita-microclínio-gnaisse foram pesquisadas por Rebertus et al. (1986). A caulinita revelou-se de comum para abundante nas frações areia de seis dos dez pedons e foi encontrada em alguma extensão em nove dos dez solos estudados. Essa caulinita é praticamente derivada de pseudomorfoses da biotita que mantem a sua morfologia, mas já apresenta propriedades óticas e estruturais da caulinita. $\mathrm{O}$ grau de caulinitização da biotita aumenta em direção à superficie do solo e o aumento do teor de argila é largamente associado como resultante da redução do tamanho da caulinita adicionada da diminuição das pseudomorfoses da biotita presentes na fração areia. Segundo Bisdom et al. (1982), três tipos de minerais secundários são distinguidos a partir da meteorização da biotita: a) minerais que retem parte da estrutura original 
(por ex: vermiculita, esmectita); b) minerais formados de soluções que têm uma composição fortemente influenciada pelos produtos do intemperismo da biotita (por ex: caulinita, gibbsita, compostos de ferro e óxidos de titânio) e c) minerais que não se formam às expensas da biotita, mas que podem ser encontrados em posições interlamelares, como por exemplo calcita e gipsita.

Cass \& Johnston (1985), trabalhando com solos australianos do sudeste, norte e áreas mais áridas do interior, estabeleceram uma correlação entre a mineralogia com problemas intrínsecos dos solos tais como: drenagem interna pobre, alta densidade e dispersão das argilas. Os resultados das investigações confirmaram que havia uma relação entre a mineralogia e o comportamento físico dos solos. Os pobremente drenados tinham tendência de serem dominados por minerais do grupo das esmectitas, enquanto que solos dispersivos e compactados, tinham uma composição mineralógica mista na fração argila composta de esmectita, mica e caulinita. Solos com drenagem livre apresentaram-se geralmente como cauliníticos. A presença de óxidos de ferro, indicados pela cor, promoveram uma melhoria sobre as propriedades físicas, reduzindo a expansão, dispersão e compactação.

Rao et al. (1985), pesquisaram a composição de caulinitas em relação ao intemperismo do material originário e ao clima em solos do sul da Índia. Os dados mostraram que o ferro era um dos elementos estruturais das caulinitas, e que a extensão da substituição do ferro por alumínio, dependia do material originário e da drenagem do perfil.

Estudos de estrutura da rocha e de balanços de intemperismo através de ganhos e perdas quando se compara a mineralogia da rocha matriz e/ou 
do horizonte C com o solum, são de considerável importância para se fazer predições a cerca da gênese de um solo. Gebhardt (1989), estudou os balanços do intemperismo pedogenético ou processos de transformação mineral no horizonte $\mathrm{Bt}$ de dois alfissolos bem drenados na região semi-árida do Brasil, e verificou que a maior quantidade de acumulação de argila foi devido quase que totalmente à sua formação in situ. A principal contribuição para a gênese de argila, resultou da transformação ou decomposição de biotitas e feldspatos da fração areia para caulinitas na fração argila. Pseudomorfoses de graus variados de intemperismo de feldspatos e biotitas para caulinitas também ocorreram.

Gomes \& Pinto (1992), estabeleceram as relações entre estrutura, intemperismo e formação de minerais secundários em três anfibolitos. Uma estrutura maciça resultou na formação de minerais $2: 1$, enquanto que uma estrutura orientada favoreceu um acentuado intemperismo com remoção de elementos e formação de minerais mais intemperizados.

Ahuja et al. (1993), pesquisando o intemperismo e a estabilidade de minerais primários e secundários em solos tropicais na Índia, em seis diferentes unidades taxonômicas e geomórficas, verificaram que a ordem de estabilidade difere sob diferentes ambientes no solo. Em solos com $\mathrm{pH}<8,5$ a estabilidade dos minerais primários obedecem à seguinte ordem: piroxênios $<$ anortita $<$ albita $<$ muscovita $<$ microclínio $<$ quartzo. Em solos com pH $>$ 8,5 as posições da albita, muscovita e microclínio são trocadas. A ordem de estabilidade para os minerais secundários na primeira condição de $\mathrm{pH}$ foi: clorita $<$ ilita $<$ caulinita $<$ montmorilonita, ao passo que em um solo sódico de $\mathrm{pH}>8,5$ a ordem foi: ilita $<$ caulinita $<$ clorita $<$ montmorilonita. As 
ordens de estabilidade foram determinadas usando um modelo termodinâmico e as curvas de estabilidade foram extraídas e interpretadas sob os valores de $-\log \mathrm{H}_{4} \mathrm{SiO}_{4}$ e $-\log$ de $\mathrm{Al}^{3+}$.

O uso da microscopia eletrônica de varredura tem-se constituido em uma ferramenta das mais importantes nos dias atuais no estudo da gênese de argilo-minerais. Eswaran (1979), utilizou microscopia eletrônica de varredura para monitorar produtos de alteração de pseudomorfoses em plagioclásios e augita. Berner \& Schott (1982), estudaram a morfologia de superficie de grãos de piroxênios e anfibólios, através da microscopia eletrônica de varredura e verificaram que tais minerais são transformados durante o intemperismo, por meio da formação, ampliação e coalescência de distintas cavidades cristalinas. Concluiram ainda, que a velocidade de dissolução desses minerais é controlada predominantemente pela reação química de superfície. Segundo Eswaran \& Shoba (1983), a microscopia eletrônica ajuda a entender os diferentes processos que atuam na formação dos minerais de argila, ao complementar os estudos de campo (macromorfologia) e micromorfológicas (microscopia ótica), dando informações qualitativas e quantitativas sobre as alterações mineralógicas e estruturais ao nível da escala do cristal. Southard \& Southard (1985), pesquisando a gênese dos horizontes $\mathrm{B}$ incipiente e argílico em dois aridissolos em Utah-EUA, concluiram ser a microscopia eletrônica de varredura uma valiosa ferramenta para inferir processos de formação do solo, especialmente em horizontes fracamente desenvolvidos. Estágios transicionais na transformação de minerais silicatados primários para minerais de argila, através do intemperismo e outros processos de alteração, 
podem ser visualmente observados com a ajuda da microscopia eletrônica de varredura. Mudanças, produtos, espécies, processos genéticos e ocorrência de diversos minerais de argila, também podem ser visualisados (Keller \& Balasubramaniam, 1989). Aoudjit et al. (1995), estudaram a gênese de esmectitas em dois saprolitos de granito, usando métodos mineralógicos convencionais e a alta resolução da microscopia eletrônica de varredura. Plagioclásios e mica induziram para a formação de diferentes tipos de esmectitas, de acordo com as condições de intemperismo ( $\mathrm{pH}$ e drenagem). Em ambiente bem drenado uma montmorilonita neoformada aparece em vazios da parte central de plagioclásios. Nas mesmas condições biotitas são transformadas em beidelitas. Sob condições mal drenadas (hidromórficas), muscovitas transformam-se incompletamente em esmectitas, ao passo que biotitas evoluem para a formação de montmorilonita. A microscopia eletrônica de varredura foi usada para avaliar o grau de meteorização de grãos de plagioclásios e feldspato alcalino em solos arenosos. Um índice morfológico de meteorização baseado na percentagem da superficie de grãos cobertos com cavidades, foi usado para avaliar a intensidade de intemperismo. Os resultados mostraram significante alteração nos horizontes superficiais e subsuperficiais em relação ao material de origem. Os plagioclásios apresentaram maiores alterações do que o feldspato potássico. Dentro dos plagioclásios o índice aumentou linearmente com o aumento do conteudo de cálcio (Rachid et al. 1995). Blanco \& Sanchez (1995), investigando a mineralogia das frações silte e argila do solum e do material originário em cinco perfis no Sudoeste da Argentina, utilizando difração de raios-X e microscopia eletrônica de varredura, concluiram ser a mineralogia 
de ambas as frações herdada do material originário e de transformações pedogenéticas. Verificaram ainda não haver relação direta entre os minerais de argila identificados e a variação espacial no regime de umidade dos solos, que variaram de údico para ústico. Miklos et al. (1996), apresentaram algumas contribuições da microscopia eletrônica de varredura na gênese de argilo-minerais e concluiram que a mesma associada às microanálises químicas são ferramentas de extrema utilidade nos estudos dos processos e mecanismos envolvidos nas alterações das rochas, nas transformações mineralógicas e microestruturais. Quando integradas à analise macromorfológica e com a microscopia ótica permite uma maior compreensão dos fenômenos que se situam na origem das alterações, nas diferentes escalas.

\subsection{Características gerais e mineralogia}

A área do Estado do Ceará é de $148.016 \mathrm{~km}^{2}$, sendo que $136.532 \mathrm{~km}^{2}$, que representam aproximadamente $92 \%$ da superfície total, estão incluidos no polígono das secas. Desse modo, as condições de semi-aridez onde predominam a maioria dos solos do Estado, apresentam regime hídrico com deficiência de água na maior parte do ano, sendo os regimes hídricos arídico ou ústico transicional para arídico os de maior probabilidade de ocorrência mormente o último. A falta de dados e/ou pesquisas diretas sobre os regimes de umidade dos solos cearenses, levam os pedólogos da região a fazerem previsões sobre os mesmos, baseados em dados de precipitação pluviométrica anual, evapotranspiração e distribuição irregular e torrencial 
das chuvas, que em muitos locais das áreas mais secas se caracterizam por o total da precipitação anual ficar concentrada em três, quatro ou cinco meses. Os Brunos Não-Cálcicos principalmente, os Planossolos Solódicos, os Solonetz Solodizados e os Podzólicos Vermelho-Amarelos Eutróficos estão mais comumente associados com as regiões de maior semi-aridez, enquanto que os Podzólicos Vermelho-Amarelos e/ou Escuros Distróficos se situam mais comumente em áreas transicionais semi-árido litoral ou em locais de maior altitude, onde as condições são mais úmidas e o regime hídrico é suposto ser tipicamente ústico à luz das interpretações que se pode fazer sobre dados climatológicos existentes.

Portanto, o Nordeste seco, onde se localiza o Estado do Ceará com cerca de $92 \%$ dos seus solos em condições de escassez de água e sujeitos a secas cíclicas, é um complexo fisiográfico, climático, hidrológico e ecológico tipicamente semi-árido. "Não há desertos, nem eolização atual ou marcas de arreismo regional ou sub-regional. Não ocorrem feições endorréicas, próprias de outras partes semi-áridas rústicas do globo. Por essa razão o semi-árido nordestino constitue-se de um mosaico de solos de regiões semiáridas quentes não sujeitas a processos areolares de salinização ou fortes concrecionamentos cálcicos. Não existem depósitos importantes de caliches ou carapaças calcáreas, atuais ou pretéritas. Desse modo, o universo dos espaços físicos e ecológicos do Nordeste Brasileiro é certamente semi-árido por possuir uma estação chuvosa, alternada com uma estação muito seca, de duração igual ou quase sempre maior em função da irregularidade na distribuição das precipitações”'(Ab’ Saber, 1996, p. 11). 


\subsubsection{Características gerais}

\subsubsection{Podzólicos Vermelho-Amarelos (PV distróficos - PVd e eutróficos - PVe)}

Esta classe compreende solos não hidromórficos, com horizonte $\mathrm{B}$ textural, argila de atividade baixa ou alta e saturação por bases baixa $(<50$ $\%)$ ou alta $(>50 \%)$. Apresentam perfis bem diferenciados com sequência $A$, $\mathrm{Bt}, \mathrm{C}$ ou $\mathrm{A}, \mathrm{E}, \mathrm{Bt}, \mathrm{C}$ de horizontes. Podem apresentar caráter abrupto e horizonte Bt com plintita. São solos de textura arenosa, média ou raramente argilosa no horizonte $\mathrm{A}$ e média ou argilosa no horizonte $\mathrm{Bt}$ e cor, nesse mesmo horizonte, variando de matizes 2.5YR a 10YR. Morfologicamente os Podzólicos Vermelho-Amarelos eutróficos são muito semelhantes aos distróficos, destes diferindo por apresentar de média a alta saturação por bases (V\% > 50), menor acidez, baixa saturação por alumínio e a fertilidade natural que varia de média a alta (Brasil, 1973). Oliveira et al. (1992), concordam com as características citadas em Brasil (1973), acrescentando ainda que tais solos apresentam teores de $\mathrm{Fe}_{2} \mathrm{O}_{3}$ inferiores a $11 \%$. Analiticamente podem ser eutróficos, distróficos ou álicos e até ácricos embora isso seja muito raro. Podem apresentar muitos minerais facilmente intemperizáveis. Segundo Camargo et al. (1987), são solos minerais não hidromórficos com horizonte B textural não plíntico, precedido de qualquer hortizonte $\mathrm{E}$ ou $\mathrm{A}$ diagnóstico, exceto turfoso, com pequeno a grande incremento de argila do A para o $\mathrm{B}$, e ausência de características distintivas de Planossolos. As propriedades diagnósticas para subdivisões da classe são: 
atividade da argila, saturação por bases e alumínio, presença de fragipan, mudança textural abrupta, solum raso, propriedades intergradacionais, tipo de horizonte A, classe textural e fases de vegetação e relevo.

Nos levantamentos de solos executados pelos convênios MADNPEA, EMBRAPA/SNLCS, SUDENE/DRN no Nordeste, esta classe de solo está englobando Podzólicos Amarelos (PA) e Podzólicos Vermelho-Escuros (PE), os quais só recentemente foram reconhecidos e passaram a ser mapeados separadamente (Jacomine, 1996). Estes últimos, diferem dos Podzólicos Vermelho-Amarelos pela coloração vermelha de tonalidade mais escura e teor de $\mathrm{Fe}_{2} \mathrm{O}_{3}$ mais elevado. Em casos de dúvidas, devido a cor vermelha insuficientemente escura, o teor de ferro é discriminatório $-\mathrm{Fe}_{2} \mathrm{O}_{3}$ $>3,75+(0,0625 \times \%$ argila), (Oliveira et al., 1992)

\subsubsection{Brunos Não-Cálcicos - NC}

São solos não hidromórficos com horizonte $B$ textural, argila de atividade alta, saturação por bases e soma de bases alta, reação moderadamente ácida a praticamente neutra, ou mesmo moderadamente alcalina, alta fertilidade natural e elevados teores de minerais primários facilmente decomponíveis. Sequência $\mathrm{A}, \mathrm{Bt}, \mathrm{C}$ ou $\mathrm{A}, \mathrm{E}, \mathrm{Bt}, \mathrm{C}$ de horizontes, textura arenosa ou média no horizonte $\mathrm{A}$ e média ou argilosa no Bt; mudança textural abrupta do A para o Bt e comumente apresentando descontinuidade litológica entre os horizontes superficiais e subsuperficiais. É muito comum nas áreas desses solos a presença de pedregosidade superficial, constituida 
por cascalhos e matacões de quartzo, caracterizando um pavimento desértico (Brasil, 1973).

Segundo Oliveira et al. (1992), são solos cuja conceituação procede da classificação americana de 1938, modificada em 1949, e o reconhecimento desses solos passou a ocorrer a partir da década de 1970, nos levantamentos de solos do Nordeste. São solos minerais pouco profundos ou rasos, não hidromórficos, eutróficos, argila de atividade alta, horizonte A fraco ou moderado, consistência dura ou muito dura quando secos, estrutura maciça ou em blocos fracamente desenvolvidos, seguido por um B textural pouco espesso, de cor nomalmente vermelha ou avermelhada, usualmente com mudança textural abrupta e estrutura em blocos moderada a fortemente desenvolvida. Apresentam relativamente altos teores de minerais primários intemperizáveis, notadamente feldspatos potássicos.

Camargo et al. (1987), definiram os Brunos Não-Cálcicos como solos minerais, não hidromórficos, com horizonte $B$ textural avermelhado vívido, bem contrastante, em sequência a um horizonte A fraco ou moderado, geralmente maciço e duro, saturação por bases alta e argila de atividade alta. Podem apresentar propriedades intergradacionais para Litólicos, Planossolos, Vertissolos, Brunizem Avermelhado e Podzólico VermelhoAmarelo. 


\subsubsection{Planossolos Solódicos - PL}

Compreende solos com horizonte B textural, normalmente com argila de atividade alta e saturação com sódio entre 6 e $15 \%$ nos horizontes $\mathrm{Bt}$ e/ou C, mostrando esses horizontes subsuperficiais aspectos associados com umidade ( mosqueado e/ou cores de redução). Têm sequência A, Bt, C ou A, $\mathrm{E}, \mathrm{Bt}, \mathrm{C}$ de horizontes, moderadamente profundos a rasos, imperfeitamente drenados, de baixa permeabilidade, em geral moderadamente ácidos a neutros, alta saturação por bases e teores elevados de mimerais intemperizáveis nos horizontes subsuperficiais, principalmente no horizonte C (Brasil, 1973). Além das características mencionadas, se caracterizam por uma elevada mudança textural abrupta entre os horizontes A ou E e um B textural de densidade relativamente elevada. O contraste textural é deveras marcante, havendo registro de um valor de 14 no Estado de Sergipe. Há citação de valor de densidade do solo de até $1,7 \mathrm{~g} / \mathrm{cm}^{3}$ no horizonte $B$. Quando o adensamento é muito elevado esse horizonte funciona como um verdadeiro pã, com porosidade total muito baixa. A estrutura do horizonte $\mathrm{Bt}$ ou Btg é comumente em blocos angulares grandes ou composta de prismática e blocos angulares grandes (Oliveira et al. 1992).

Segundo Camargo et al. (1987), os Planossolos são solos minerais com horizonte B textural, mudança textural abrupta, conjugada com marcante transição de horizontes, originando quando seco, uma fratura de separação entre o horizonte A ou E e o horizonte subjacente B textural, cujas cores são pouco vivas e comumente policrômico. 
De acordo com critérios estabelecidos recentemente pela Embrapa (1988), valores de saturação por sódio trocável maiores que $20 \%$ identificam o caráter sódico no horizonte, enquanto que percentuais de $\mathrm{Na}^{+}$ maiores que 8 e menores que 20, caracterizam o caráter solódico. Portanto, os Planossolos Solódicos devem apresentar nos horizontes Btn e/ou Cn esses valores citados acima.

\subsubsection{Solonetz-Solodizado - SS}

Solos sódicos ou alcalinos com alta saturação de sódio (Driessen \& Dudal, 1991)..

A conceituação da classe dos Solonetz-Solodizados tem origem na classificação americana de Baldwin et al. (1938), posteriormente modificada por Thorp \& Smith (1949). Compreende solos minerais hidromórficos ou não, com horizonte $\mathrm{B}$ nátrico abaixo de um $\mathrm{E}$ álbico ou não ou abaixo de um A, com o qual apresenta grande contraste quanto à estrutura e textura. Há amplo predomínio de solos com argila de atividade alta, com altos valores de $\mathrm{S}$ e V \% (Oliveira et al. 1992). Ainda segundo esses autores, tais solos apresentam grande semelhança com os Planossolos Solódicos em termos de morfologia; no entanto a presença de estrutura colunar os diferenciam dos Planossolos. Quando a estrutura é prismática principalmente se composta de blocos, necessário se faz a obtenção de dados analíticos de $\mathrm{Na}^{+}$trocável e da CTC do perfil para se poder fazer a diferenciação.

Segundo Camargo et al. (1987), são solos minerais com horizonte B nátrico, precedido de qualquer horizonte diagnóstico $\mathrm{E}$, ou de $\mathrm{A}$ moderado 
ou fraco, bem contrastante com o horizonte $\mathrm{B}$ nátrico, usualmente de cor desbotada. As propriedades diagnósticas para divisões subsequentes da classe são: atividade da argila, saturação por bases, presença de fragipan, duripan, mudança textural abrupta, carbonato de cálcio remanescente, propriedades intergradacionais, tipo de horizonte $\mathrm{A}$, classe textural e fases de vegetação e relevo.

Buckman \& Brady (1974) e Thompson (1965), afirmaram que quando uma alta concentração de sódio torna-se associada com os colóides do solo, um tipo de solo é formado, recebendo a denominação de solo alcalino ou Solonetz-Solodizado. $\mathrm{O}$ pH desse solo está acima de 8,5 devido ao sódio adsorvido ao complexo de troca e a presença de carbonato de sódio. A \% de $\mathrm{Na}^{+}$é superior a $15 \%$. Os colóides orgânicos e inorgânicos tornam-se dispersos e a cor escura da crosta superficial que pode ser observada é devido a matéria orgânica dispersada. O perfil desenvolvido como resultado desse processo é muito característico. Abaixo de uma camada muito friável e delgada é encontrado um horizonte de argila pesada, com estrutura colunar, permitindo um Solonetz-Solodizado ser facilmente identificado no campo.

Klages (1966), cita que o Solonetz-Solodizado é caracterizado por possuir uma estrutura indesejável no horizonte $\mathrm{B}$. O mesmo autor afirma que os Solonetz-Solodizados nem sempre apresentam alto teor em sódio, podendo ter em vez disto, um elevado teor de magnésio. Os teores de sódio e magnésio e o elevado grau de expansão das argilas, são particularmente responsáveis pela baixa agregação e permeabilidade do horizonte Btn.

Mohr \& Van Baren (1959), estudando solos alcalinos, verificaram que o cloreto de sódio, sulfato de sódio ou o carbonato de sódio são os 
responsáveis por distintas características destes solos. Descrevem que, quando há predominância de cloretos e/ou sulfatos, os solos são geralmente chamados de Solonchak; quando o carbonato é elevado, os solos são agrupados como alcalinos pretos ou Solonetz.

Integram esta classe solos halomórficos com horizonte B solonétzico ou nátrico, o qual constitui uma modalidade especial de horizonte $\mathrm{B}$ textural, tendo saturação com sódio trocável ( $100 \mathrm{Na}^{+} / \mathrm{T}$ ) igual ou maior que $20 \%$ nos horizontes $\mathrm{B}$ e/ou $\mathrm{C}$, normalmente possuindo nestes horizontes subsuperficiais estrutura colunar ou prismática. Se um horizonte subjacente C tem em alguma parte mais que $20 \%$ de sódio um horizonte B textural sobrejacente que tenha $\mathrm{Mg}^{++}+\mathrm{Na}^{+}$maior que $\mathrm{Ca}^{++}+\mathrm{H}^{+}$, é considerado um B solonétzico.

São solos rasos a moderadamente profundos, bem diferenciados, possuindo sequência de horizontes $\mathrm{A}, \mathrm{Btn}, \mathrm{Cn}$ ou $\mathrm{A}, \mathrm{E}, \mathrm{Btn}, \mathrm{Cn}$ com profundidade do $\mathrm{A}+\mathrm{Btn}$ ou $\mathrm{A}+\mathrm{E}+\mathrm{Btn}$ entre 20 e $100 \mathrm{~cm}$, com mudança textural abrupta do A para o Btn, cujo gradiente textural situa-se comumente entre 3,0 e 9,0. São imperfeitamente ou mal drenados, com permeabilidade lenta a muito lenta no subsolo, muito susceptíveis a erosão e com reação moderadamente ácida a praticamente neutra e alcalina nos horizontes Btn e $\mathrm{C}$, os quais apresentam também altos valores para soma de bases trocáveis (S), saturação por bases (V\%) e saturação com sódio trocável, principalmente no horizonte C (Brasil, 1973).

Oliveira et al. ( 1992), concordam com as características mencionadas em Brasil (1973), sugerindo ainda que a relação textural B/A, pode ser mais elevada ainda, havendo ocorrência de valor 11 no Estado de Sergipe. Os 
mesmos autores citaram o que também é mencionado por Prado (1993), que há registro no Brasil de Solonetz-Solodizado que além do caráter alcalino, apresenta também em profundidade o salino, sendo por conseguinte, intermediário com os Solonchaks.

\subsubsection{Gênese do horizonte B textural}

Todos os solos objeto da pesquisa em apreço, se caracterizam por apresentarem horizonte subsuperficial do tipo B textural (nove perfis), e um perfil de Solonetz Solodizado com horizonte nátrico, que como sabemos se constitui em uma modalidade especial de horizonte B textural com alta saturação de sódio trocável. De acordo com o sistema brasileiro de classificação de solos, ainda em fase de elaboração definitiva, o horizonte B textural é um horizonte subsuperficial de acumulação de argila orientada ou não, que na classificação americana de solos ( Soil Survey Staff, 1975) é equivalente ao argillic horizon enquanto que no sistema FAO-UNESCO corresponde ao argic horizon ( Oliveira \& van den Berg, 1996), com alguns critérios adicionais ou específicos usados no sistema brasileiro, em relação aos dois sistemas supra citados. O horizonte B nátrico do sistema brasileiro tem definições equivalentes ao natric horizon ( Soil Survey Staff, 1975) e ao natric B horizon da FAO-UNESCO ( Oliveira \& van den Berg, 1996); embora mais recentemente o mínimo de sódio trocável para caracterizar o horizonte nátrico no sistema brasileiro, tenha sido aumentado de $15 \%$ para 20\% ( Embrapa, 1988), para se ajustar às diferenças de métodos de análises. 
Nas condições de semi-aridez do Estado do Ceará, verifica-se mais comumente nos solos estudados, uma sequência A-Bt-C de horizontes sobrepujando largamente àqueles de sequência A-E-Bt-C. Como essa região semi-árida em sua quase totalidade, está associada com uma geologia de rochas cristalinas, principalmente rochas metamórficas referidas ao PréCambriano Indiviso com uma predominância absoluta de gnaisses e de migmatitos, existe uma forte evidência de que o horizonte B textural nas condições acima mencionadas, seja formado predominantemente "in situ" (autóctone), com poucas evidências de iluviação ( carente mesmo assim de estudos micromorfológicos detalhados) para confirmar tal fato. Embora seja comum nos agregados estruturais desses solos a presença de superficies brilhantes e cerosas (cerosidade), isso necessariamente não significa uma forte contribuição de argila iluvial na gênese do horizonte $\mathrm{Bt}$ na região semiárida do Estado do Ceará. Por outro lado o horizonte superficial também na maior parte dos solos estudados, devido à geomorfologia da região e a ocorrência frequente de linha de pedras("stonelines"), separando o horizonte Ae/ou E do B textural, leva-nos a supor da sua origem pedimentar a partir de material depositado sobre o $\mathrm{Bt}$ e retrabalhado localmente. Estudos quantitativos de minerais índices ou estáveis ou dos elementos que os compõem (zircônio, titânio, quartzo e albita ajudam a solucionar e/ou confirmar tal processo ( Chapman \& Horn, 1968; Fost \& Rust, 1968; Sudom \& St. Amaud, 1971; Drees \& Wilding, 1973; Demattê, 1978; Santos et al., 1986; Rabenhorst \& Wilding, 1986; Luz et al., 1992 e Stolt et al., 1993 ).

Os constituintes considerados estáveis ou pouco móveis no solo são relativamente poucos e a escolha destes em estudos de desenvolvimento do 
solo está estreitamente associado com o clima. Zircão e quartzo têm sido usados com mais frequência, devido as suas aparentes estabilidades relativas sob uma grande variedade de condições (Brewer, 1976). Embora o zircão seja relativamente mais estável do que o quartzo sob condições tropicais úmidas, em clima semi-árido este último pode ser usado com relativa segurança, além das vantagens que apresenta de ser mais abundante e sua determinação quantitativa por microscopia ótica ser mais simples e precisa.

A gênese do horizonte B textural, qualquer que seja a classe de solo onde o mesmo seja encontrado, requer períodos anuais ou cíclicos no qual o solum ou uma parte significante do mesmo esteja seco ou seja abaixo do ponto de murchamento permanente ( Soil Survey Staff, 1975).

De acordo com Birkeland (1984), três são os processos principais para a formação do horizonte B textural: a) formação e acumulação de argila no próprio local (in situ), através da alteração de minerais primários; b) translocação descendente das argilas em solução na água, a partir da alteração de minerais na zona superior do perfil, sendo as mesmas acumuladas no B textural e c) transporte de argilas em suspensão na água de percolação e posterior deposição no horizonte $\mathrm{B}$, devido à floculação ou a diminuição dos poros por onde a água se movimenta. A conclusão final do autor é que na realidade a gênese do Bt pode ser atribuida aos três processos, porém a predominância de cada um varia com a classe de solo e achamos que também com a natureza da rocha matriz e principalmente com o clima.

A simples constatação de acúmulo de argila em determinada parte do perfil, a presença de cerosidade ou os dois processos conjugados não 
significam obrigatoriamente que a presença de cutãs de iluviação sejam detectados em lâminas delgadas ao serem observadas no microscópio ótico. Nettleton et al. (1969), reportaram sobre a ocorrência de muitos solos com acúmulo de argila e cerosidade no $\mathrm{B}$, mas sem evidências de cutãs de iluviação em lâminas delgadas. Segundo tais autores, fenômenos de expansão e contração devido a umedecimento e secagem do solo, podem permitir a gênese de argilas orientadas in situ (cutãs de estresse) e ao mesmo tempo induzir à destruição dos cutãs iluviais. Gebhardt (1989), atribuiu à alteração in situ de minerais primários presentes na fração areia, como o processo predominante na formação do horizonte $B$ textural de alfissolos na região semi-árida do Nordeste do Brasil. Koppi \& Williams (1980), estudando a gênese do horizonte Bt em dois solos derivados de granodiorito, no Sudeste da Austrália, verificaram ser a biotita a principal fonte de formação de minerais de argila (hidrobiotita, vermiculita, esmectita e caulim). Concluiram também que a argiluviação, parece ser insignificante na formação do horizonte de máximo teor de argila. Conclusão semelhante obtiveram Alias \& Albaladejo (1978), trabalhando com dois solos apresentando horizonte Bt. Isbell (1980), também concluiu em pesquisa de revisão sobre a origem do horizonte B textural, que a presença de cerosidade e acumulação de argila observadas no campo, em muitos casos não se correlacionavam com a quantidade de cutãs de iluviação em lâminas delgadas, evidenciando portanto a maior contribuição da formação "in situ" na gênese do horizonte $\mathrm{Bt}$.

Em regiões mais secas o processo de iluviação de argilas é teoricamente menos intenso do que a origem in situ, considerando-se as 
condições climáticas vigentes como aquelas em que o solo foi originado, pois quatro são as alternativas citadas por Eswaran \& Sys (1979), para que a argiluviação seja um processo intenso em solos com horizonte B textural: a) condições de dispersão para as argilas no horizonte eluvial; b) como as argilas são translocadas pela água, deve existir no solo uma densidade de fluxo periódico desse líquido para que as argilas possam ser transportadas e depositadas; c) o horizonte chamado iluvial deve está apto para ser o local de deposição e d) a pedoturbação deve ser a menor possível a fim de não ocorrer destruição da argila translocada e depositada. De acordo com Nettleton \& Peterson (1983), a gênese do horizonte Bt em aridissolos é especialmente duvidosa, pois muitos desses solos não apresentam cerosidade no campo, o que leva a supor da pouca participação de argila iluviada na sua formação. Também a destruição da cerosidade nos horizontes que afloram próximo à superficie através da bioturbação e/ou fenômenos de contração e dilatação não está bastante justificada. Em trabalho recente de revisão de literatura, sobre a evolução dos conceitos no estudo da gênese de solos, Moniz (1996), destacou a falta de um paradigma que oriente as pesquisas nesse setor de estudo. Destaca a necessidade de uma abordagem interdisciplinar, com ênfase na mecânica de solos, para a criação de novos paradigmas. Concluiu ainda, que o processo de argiluviação isolado, não é suficiente para explicar a gênese de horizontes $\mathrm{Bt}$ a partir de horizontes $\mathrm{Bw}$; e que o fenômeno de adensamento por dessecação se constitui em um importante subsídio para a compreensão dos processos de formação de horizontes $\mathrm{Bt}$ a partir de $\mathrm{Bw}$ e de outros materiais 
A composição catiônica básica do horizonte $\mathrm{B}$ textural é geralmente dominada por $\mathrm{Ca}$ e $\mathrm{Mg}$, com menores quantidades de $\mathrm{Na}$ e $\mathrm{K}$. Quando o sódio trocável passa a constituir mais de $15 \%$ do complexo de troca, o horizonte assume características peculiares não somente no que se refere aos processos de contração e dilatação, mas também em relação ao balanço de nutrientes. O horizonte $\mathrm{Bt}$ ao assumir esses atributos passa a se chamar nátrico e morfologicamente se caracteriza por alguma destruição da parte superior do Bt, devido ao efeito desfloculante do sódio (Rust, 1983).

Não somente o conteúdo de sódio da umidade do solo é importante mas também a concentração de outros ions, particularmente ions bivalentes que são preferencialmente adsorvidos no complexo de troca. A relação de adsorção de sódio $\mathrm{SAR}=\mathrm{Na}^{+} /\left[\left(\mathrm{Ca}^{2+}+\mathrm{Mg}^{2+}\right) / 2\right]^{0,5}$ é uma medida da composição da solução do solo, como relevante para a adsorção do $\mathrm{Na}^{+}$no complexo de troca de cations. O horizonte nátrico bem formado apresenta uma estrutura colunar com topos superiores arredondados, como resultado de peptização e destruição de argilas. O processo fica limitado ao topo do B em razão da estagnação da percolação da água sobre essa camada densa e enriquecida de argila (Driessen \& Dudal, 1991).

Embora um horizonte nátrico possa se originar a partir de um estágio inicial de salinização ( Solonchak ), devido a lixiviação dos sais solúveis por processos geomórficos ou naturais, ficando o complexo de troca saturado dominantemente por sódio; nas regiões semi-áridas e em condições de drenagem deficiente, a alteração de minerais primários ricos em sódio parece ser a fonte principal de acumulação desse ion no solo. O intemperismo da albita e de outros plagioclásios com teores elevados de sódio, é reconhecido 
como um dos caminhos para a gênese do horizonte nátrico, mesmo em climas úmidos se a drenagem é impedida (Wilding et al. 1963).

\subsubsection{Mineralogia}

Há considerável incerteza sobre a extensão do intemperismo e neossíntese de minerais em solos áridos (Boettinger \& Southard, 1995)

Alfissolos e aridissolos ocorrem com certa frequência em regiões tropicais secas do mundo, mas raros e definitivos estudos de alterações no ambiente climático acima citado a nível de Brasil, têm sido conduzidos. A mineralogia dos alfissolos na fração argila varia grandemente desde ilitas, esmectitas, vermiculitas, caulinitas e até mesmo carbonatos. Por sua vez os aridissolos com horizonte argílico, também apresentam uma variação relativamente grande em sua mineralogia, encontrando-se solos até essencialmente cauliníticos; embora a mineralogia mais comum associada aos mesmos sejam de misturas (mixed), esmectitas e carbonatos (Allen \& Fanning, 1983). A mineralogia das frações de diâmetro superior ao da argila, normalmente está associada com a natureza dos diferentes materiais de origem desses solos.

Os estudos pioneiros sobre a mineralogia de solos no Estado do Ceará, embora restritos às frações mais grosseiras do solo (areias e cascalhos) foram executados quando da realização do Levantamento Exploratório-Reconhecimento de Solos do Estado do Ceará (Brasil, 1973). O mesmo pode-se dizer para a região Nordeste do Brasil, cujas investigações 
em mineralogia de solos, iniciou-se com os levantamentos de solos efetuados por instituições oficiais nos Estados da região.

Estudando a mineralogia da fração areia com as classes de solos ora investigadas, durante a realização do Levantamento ExploratórioReconhecimento de Solos do Estado do Ceará, encontrou-se em Podzólico Vermelho-Amarelo distrófico predominância de quartzo, muscovita e traços de feldspatos e biotita. Nos eutróficos, também o quartzo foi predominante seguido de perto por feldspatos alcalinos, plagioclásios e em menor proporção ou na forma de traços, biotita e ilmenita. Em solos Bruno NãoCálcico, foi verificado ocorrência de quartzo, associado com biotita, hornblenda, e feldspatos, cujos percentuais variavam em função da natureza do material originário do solo. No Planossolo Solódico, quartzo, feldspato alcalino, e biotita foram os mais frequentes, enquanto que no SolonetzSolodizado, quartzo, feldspatos semi-intemperizados e traços de muscovita foram os mais encontrados. Esses resultados foram inerentes aos horizontes B e C do perfil (Brasil, 1973).

Souza (1986), pesquisando a mineralogia da fração argila de solos Bruno Não-Cálcico do Estado de Pernambuco, encontrou caulinita e montmorilonita como sendo os argilo-minerais mais frequentes na mencionada fração.

Smith \& Buol (1968), relataram que a formação de argila in situ em horizontes argílicos de regiões semi-áridas em Illinois, não é a única responsável pela gênese desses horizontes. A formação desse horizonte diagnóstico, provavelmente decorre desse processo, associado com argila iluvial, proveniente dos horizontes eluviais. 
Schmehl \& Jackson (1956), McNeal (1964) e Klages (1968), encontraram a presença de minerais de argila com alto grau de interestratificação em solos de clima semi-árido nos Estados Unidos e Canadá.

A composição mineralógica e as transformações mais comuns que ocorrem em Aridisols foram apresentadas por Allen \& Fanning (1983). Segundo esses autores nos argids predominam misturas de minerais (mixed) ou montmorilonita na fração argila, enquanto que nos orthids prevalecem misturas, carbonatos, montmorilonita e gipsita. As transformações são lentas devido o clima seco. Aridisols fortemente cauliníticos nos Estados Unidos são muito raros mas em outras áreas tropicais semi-áridas, um número crescente de solos cauliníticos têm sido citados.

Buol \& Yesilsoy (1964), citaram que ilita e caulinita dominavam a fração argila da parte superior do solo, enquanto que montmorilonita, coincidindo com uma descontinuidade litológica, era mais comum na parte inferior do perfil em um argids do Arizona- U.S.A. A presença de haloisita foi também comum ao longo do perfil, o que segundo os mesmos autores, tratava-se de uma observação relativamente rara em argilas de aridisols.

Solos vermelhos latossólicos e podzólicos em área semi-árida próxima a Jequié-Bahia, foram estudados por Volkoff \& Ribeiro (1979). A precipitação média anual é de cerca de $700 \mathrm{~mm}$ e a vegetação de caatinga. Nos Podzólicos o material intemperizado apresentou minerais de argila 2:1 e goetita. Como a esmectita desapareceu em direção à superficie e a goetita se transformou em hematita a cor vermelha gradualmente se desenvolveu. Tais modificações mineralógicas mostraram que nas referidas condições 
climáticas, a esmectita e a goetita formadas pelo intemperismo são instáveis. É concluido que caulinita e hematita é a paragênese normal na região. Melo (1980), também avaliou a mineralogia das frações argila e silte fino em seis pedons em Uruçuca-Bahia através de difração de raios-X. Caulinita e metahaloisita foram os minerais predominantes, porém goetita e gibbsita foram frequentes. Pequenas quantidades de talco, esmectita, mica e minerais interestratificados foram também detectados.

Saxena \& Singh (1983), pesquisaram a mineralogia da fração argila de solos Bruno Não-Cálcicos ocorrentes na região semi-árida de RajasthanIndia. Minerais do grupo das esmectitas (montmorilonita) foram predominantes.

Trabalhando com dois alfissolos (Haplustalfs), Tomar et al. (1985), constataram a predominância de caulinita e esmectita na argila grossa e caulinita e vermiculita no silte fino. Minerais interestratificados envolvendo camadas de ilita-vermiculita-esmectita-clorita, foram também encontrados na fração argila.

Antonello (1989), interpretando a mineralogia da fração areia em solos do Estado de Pernambuco, encontrou em solos Bruno Não-Cálcicos a presença dos minerais feldspato, mica, anfibólio e magnetita. Com relação às frações argila e silte, também no Estado de Pernambuco, Almeida (1989), detectou em Planossolos Solódicos e Brunos Não-Cálcicos Vérticos, que a caulinita aumentava do horizonte $\mathrm{C}$ para o horizonte $\mathrm{A}$, enquanto que o teor de montmorilonita diminuia na mesma direção. A percentagem de mica/ilita foi inferior a $10 \%$ em todos os horizontes dos perfis pesquisados. 
Através da caracterização e estudo da gênese de três pedons de Solonetz-Solodizado no semi-árido cearense, Moreira (1979), concluiu serem esses solos pouco intemperizados, caracterizando-se pela predominância de feldspatos potássicos e plagioclásios calco-sódicos, assim como pelos argilo minerais montmorilonita e mica. Foi também evidenciada a seguinte sequência de intemperismo: feldspato - ilita - montmorilonita caulinita.

Batista (1988), investigando solos do semi-árido da Paraiba afetados por sódio, verificou em Planossolo Solódico, na fração silte, presença de mica e esmectitas e na fração argila esmectita, mica e caulinita, sendo que a primeira é mais significativa no horizonte $2 \mathrm{C}$, diminuindo em direção à superficie com o aumento relativo de mica e de caulinita. Na fração areia os minerais mais frequentes são microclínio e ortoclásio, além de plagioclásios (andesina). O mesmo autor, estudando dois perfis de Solonetz-Solodizado, também do semi-árido paraibano, encontrou na fração silte, feldspato, quartzo, hornblenda e mica. Já na fração argila, foi observado caulinita e vermiculita-esmectita. Os teores de minerais expansivos decrescem na direção da superficie, em relação a caulinita, sem um correspondente aumento de mica. No que se refere à fração areia, constatou-se a presença de plagioclásio sódico e hornblenda.

Oito perfis de Podzólicos Vermelho-Amarelos Tb álicos, eutróficos ou distróficos, do sertão de Pernambuco, foram caracterizados e estudados por Ribeiro et al. (1991), onde foi observado que o quartzo era o principal componente das frações silte e areia, enquanto que a mineralogia da argila era verticalmente uniforme e constituida por caulinita. 
Luz et al. (1992), pesquisando uma topossequência de solos Brunos Não-Cálcicos e Planossolo Solódico no semi-árido pernambucano, observaram que as principais diferenças entre esses solos estão subordinadas ao condicionamento de suas posições ao longo do relevo. Transformações de micas ( biotitas) em vermiculitas trioctaédricas e estas em esmectitas são também processos atuantes nesses solos. Verificaram uma diminuição de esmectita e um aumento de caulinita na direção dos horizontes superficiais.

Souza et al. (1993), estudando solos do baixio de Irecê-Bahia, observaram em Podzólicos Amarelos eutróficos, o mineral quartzo como dominante nas frações areia e silte, por outro lado a fração argila era constituida por caulinita e traços de mica.

Costa (1994), investigando a mineralogia do separado argila em Podzólicos Vermelho-Amarelos eutróficos e distróficos, na região de Ribeira do Pombal-Bahia, encontraram nos Podzólicos eutróficos, esmectita, vermiculita, mica, caulinita e goethita. Já no Podzólico distrófico, foram identificados: caulinita, goethita, mica e anatásio. O mesmo autor verificou em Solonetz Solodizado, também na fração argila, os minerais: caulinita, mica e anatásio; e em Planossolo Solódico, esmectita, caulinita e mica, de acordo com a ordem de dominância estimada pela observação dos difratogramas de raios X. Também, Ribeiro et al. (1995), em Cruz das Almas-Bahia, observaram em Podzólico Vermelho-Amarelo distrófico, predominância de caulinita e goethita na fração argila.

Alves \& Ribeiro (1995), em trabalho de caracterização e gênese de solos na microrregião da Mata Seca de Pernambuco, concluiram em Podzólico Vermelho-Amarelo Tb distrófico, que a mineralogia da fração 
areia nos horizontes Ap e Bt era constituida essencialmente por quartzo e no horizonte $\mathrm{C}$ por quartzo associado a feldspatos argilizados e micas. A partícula argila desse solo era formada principalmente por mica e caulinita, sendo essa última o principal componente, provavelmente produto da intemperização direta de feldspatos e micas. Em Planossolos Solódicos, os mesmos autores encontraram na fração areia do horizonte A predominantemente quartzo, e no $\mathrm{Bt}$ fragmentos de rocha granítica contendo principalmente quartzo, mica e raros feldspatos. No separado argila, foi encontrado no horizonte Ap a presença de caulinita e mica e, no Bt na lâmina saturada com magnésio, foi evidenciado um mineral interestratificado irregular da caulinita e mica com uma fase expansiva.

Ao realizarem a caracterização mineralógica de alguns solos do Rio Grande do Sul, Melo et al. (1995), encontraram em Podzólico VermelhoAmarelo predominância de quartzo e mica na fração areia, enquanto que nas frações silte e argila, o solo apresentou-se essencialmente quartzoso na primeira fração e essencialmente caulinítico no separado mais fino.

Moniz et al. (1995), pesquisando a mineralogia da fração argila de solos da folha de Piracicaba-SP, derivados de diferentes formações geológicas, verificaram que os minerais de argila originados de rochas sedimentares, permanecem em solos com B textural, entre os quais estão incluidos Podzólicos Vermelho-Amarelos Tb e Tm eutróficos, como ilita, esmectita, interestratificado ilita-esmectita e caulinita. A caulinita é o argilomineral mais estável e tende a se concentrar no solo, quer seja herdado da rocha sedimentar, quer seja produto da alteração do intemperismo. 
Estudando uma sequência de solos em zona semi-árida no município de Valente-Bahia, Góis (1995), encontrou em Planossolo Solódico Ta, uma mineralogia na fração argila constituida basicamente por montmorilonita, mica e caulinita.

Gomes \& Moreira ( 1995), investigando a mineralogia de Solonetz Solodizado, na região de Morada Nova-Ceará, encontraram a predominância dos minerais albita e quartzo nas partículas de silte; por outro lado, as partículas de argila apresentaram-se constituidas de mica, caulinita, quartzo e interestratificados pouco definidos com presença de montmorilonita. 


\section{MATERIAL E MÉTODOS}

\subsection{Material}

\subsubsection{Solos}

Os solos utilizados na presente pesquisa, pertencem às classes dos Podzólicos Vermelho-Amarelos, Brunos Não-Cálcicos, Planossolos Solódicos e Solonetz Solodizados, sendo bastante representativos do semiárido cearense, conforme dados do Levantamento ExploratórioReconhecimento de Solos do Estado do Ceará (Brasil, 1973).

Em termos de área os Podzólicos incluidos os eutróficos e distróficos, cobrem aproximadamente $34.120 \mathrm{Km}^{2}$, o que corresponde a $23 \%$ da área total do Estado. Por sua vez, os Brunos Não-Cálcicos englobam cerca de $26.993 \mathrm{Km}^{2}$, equivalente a 17,9 \%, enquanto que os Planossolos Solódicos associados aos Solonetz-Solodizados e Solonchak Solonétzicos abrangem em torno de $21.900 \mathrm{Km}^{2}$, o que representa percentualmente $14,8 \%$ da superficie total do Estado do Ceará.

\subsubsection{Descrição e características das áreas de estudo}

Os perfis estudados em número de onze, estão localizados em diferentes municípios e zonas fisiográficas conforme tabela 1 e 


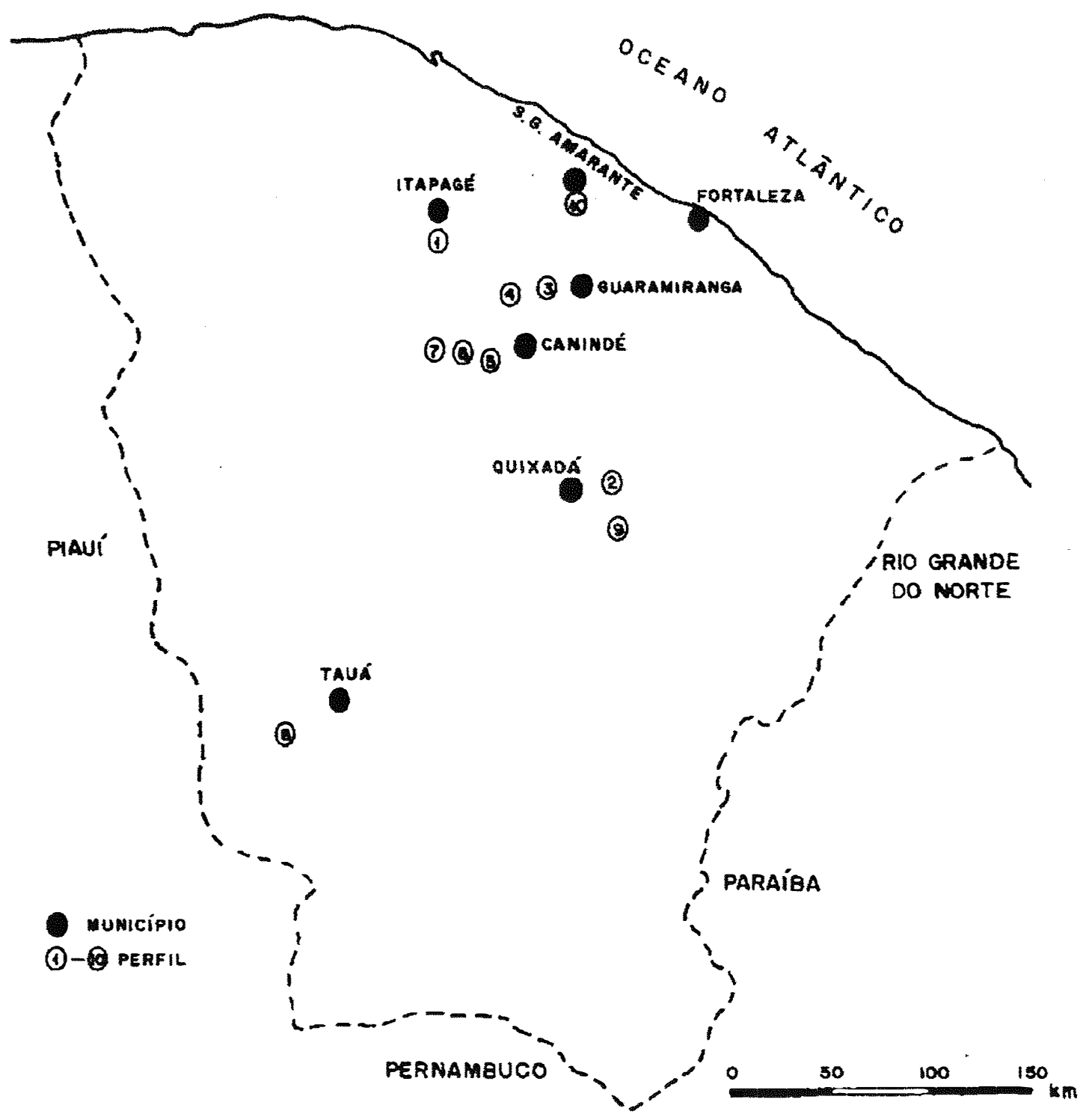

Figura 1 - Localização dos perfis em diferentes municípios no Estado do Ceará. 


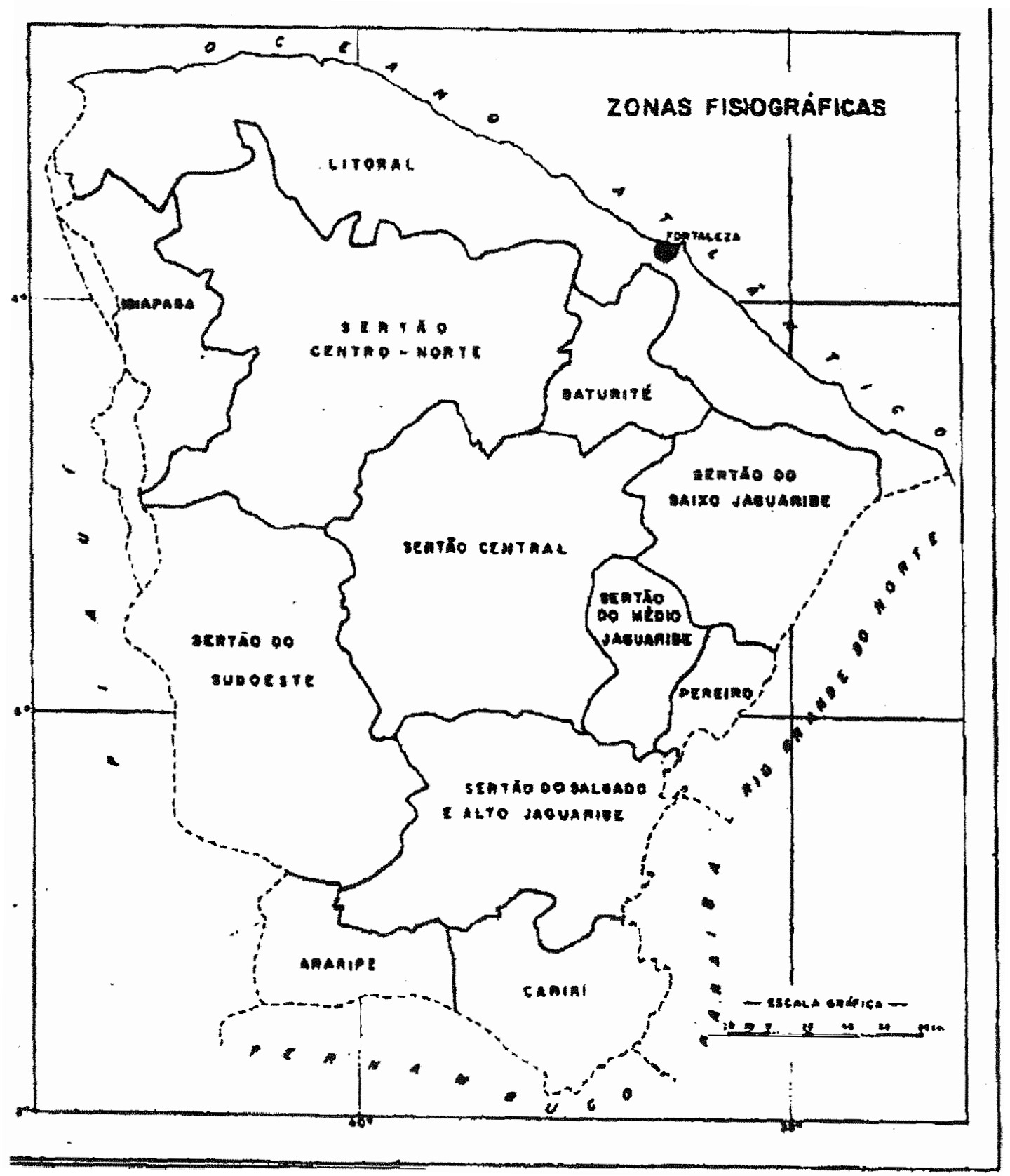

Figura 2 - Zonas fisiográficas do Estado do Ceará.

figuras 1 e 2 e e foram descritos e coletados seguindo as normas de Lemos \& Santos (1984). Os perfis 6 e 7 embora não estejam localizados em área tipicamente semi-árida, já que geomorfologicamente estão associados ao 
domínio geológico dos planaltos residuais, foram incluidos na pesquisa para o estabelecimento de comparação com os outros perfis, os quais estão morfoclimaticamente correlacionados com a semi-aridez .

Tabela 1 - Localização dos perfis de solos estudados.

\begin{tabular}{|c|c|c|c|}
\hline Classe de Solo & $\begin{array}{c}\text { Número } \\
\text { do } \\
\text { Perfil }\end{array}$ & Município & $\begin{array}{c}\text { Zona } \\
\text { Fisiográfica }\end{array}$ \\
\hline $\begin{array}{l}\text { Podzólico Vermelho-Amarelo Eutrófico } \\
\text { (PVe) }\end{array}$ & 10 & Itapagé & $\begin{array}{l}\text { Sertão Centro } \\
\text { Norte }\end{array}$ \\
\hline $\begin{array}{l}\text { Podzólico Vermelho-Amarelo Eutrófico } \\
\text { (PVe) }\end{array}$ & 1 & Quixadá & Sertão Central \\
\hline Podzólico Vermelho-Escuro Álico (PEa) & 6 & Guaramiranga & Baturité \\
\hline Podzólico Vermelho-Amarelo Álico(PVa) & 7 & Guaramiranga & Baturité \\
\hline Bruno Não-Cálcico (NC) & 3 & Canindé & $\begin{array}{l}\text { Sertão Centro } \\
\text { Norte }\end{array}$ \\
\hline Bruno Não-Cálcico Litólico (NCL) & 4 & Canindé & $\begin{array}{l}\text { Sertão Centro } \\
\text { Norte }\end{array}$ \\
\hline Bruno Não-Cálcico Vértico (NCv) & 5 & Canindé & $\begin{array}{l}\text { Sertão Centro } \\
\text { Norte }\end{array}$ \\
\hline Planossolo Solódico (PL) & 8 & Tauá & Sertão do Sudoeste \\
\hline Planossolo Solódico (PL) & 2 & Quixadá & Sertão Central \\
\hline Solonetz-Solodizado (SS) & 11 & S. G. Amar. & Litoral \\
\hline Aluvial (AL) & 9 & Tauá & Sertão do Sudoeste \\
\hline
\end{tabular}

\subsubsection{Clima}

A posição do Estado do Ceará em relação ao hemisfério sul a baixa latitude, a orientação do litoral e a posição das serras, são fatores determinantes das condições climáticas reinantes no Estado.

Os Podzólicos Vermelho-Amarelos álicos situam-se em áreas de clima Amw' na classificação de Köeppen e 4cTh, conforme a classificação de 
de Gaussen. Os eutróficos ocorrem em áreas de clima Bsw'h' de Köeppen e 4aTh de Gaussen (Brasil, 1973).

Os Brunos Não-Cálcicos localizam-se em área de clima Bsw'h' da classificação de Köeppen e 4aTh na classificação de Gaussen. Por sua vez os Planossolos Solódicos situam nas mesmas condições de clima dos Brunos Não-Cálcicos, e o Solonetz Solodizado, que ocorre mais próximo do litoral, em clima Aw'e 4bTh onde a precipitação é mais elevada (Brasil, 1973).

A seguir um breve resumo dos climas mencionados:

Amw'( clima tropical chuvoso de monção com seca atenuada ). Precipitação pluviométrica média anual em torno de $1600 \mathrm{~mm}$, com $34 \mathrm{~mm}$ para o mês mais seco ( agosto ) e $330 \mathrm{~mm}$ para o mês mais chuvoso ( abril ).

Aw'( Clima tropical chuvoso transicional para semi-árido ). Em São Gonçalo do Amarante a normal para a precipitação pluviométrica média anual situa-se em torno de $1000 \mathrm{~mm}$.

Bsw'h'( Clima quente e semi-árido ). Temperatura superior a $18^{\circ} \mathrm{C}$ no mês mais frio. A precipitação pluviométrica média anual varia de $600 \mathrm{~mm}$ (Tauá) a 830 mm (Quixadá).

4aTh ( Tropical quente de seca acentuada). Indice xerotérmico entre 150 e 200. Número de meses secos entre 7 e 8 , sendo resultado da ação da Massa Equatorial Atlântica que é uma massa estável. A curta estação chuvosa é decorrente das penetrações da Massa Equatorial Continental e das descidas da Frente Intertropical. 
4bTh ( Tropical quente de seca média ). Indice xerotérnico entre 100 e 150. Número de meses secos entre 5 e 6.

4cTh ( Tropical quente de seca atenuada). Indice xerotérmico entre 40 e 100 . Número de meses secos entre 3 e 4 . Na região de Guaramiranga a maior altitude e a exposição aos ventos úmidos, proporcionam temperaturas mais amenas, com a média do mês mais frio ( julho ), entre 15 e $20^{\circ} \mathrm{C}$.

\subsubsection{Vegetação}

A vegetação associada com os Podzólicos Vermelho-Amarelos distróficos e/ou álicos, é a floresta subperenifólia, que é uma formação densa de porte alto, normalmente com folhas de tamanho médio, esgalhamento aberto e rica em espécies. No Estado do Ceará é característica de regiões de altitude (mais de $600 \mathrm{~m}$ ), onde são conhecidas com o nome de matas das serras úmidas (Brasil, 1973). Nesses locais a temperatura é mais baixa, provocando a condensação de nevoeiros e consequentemente uma maior umidade. Entre as espécies mais importantes podem ser citadas: a) Leguminosae - Inga bahiensis Benth (Ingá), Hymenaea sp. (Jatobá), Erythrina sp. (Mulungu),Anadenanthera macrocarpa (Benth) Brenan (Angico) ; b) Borraginaceae - Cordia sp. (Frei Jorge) ; c) Bignoniaceae Tabebuia spp. (Pau Darco Roxo e Amarelo) ; d) Palmae - Orbygnia martiana B. Rodr. (Babaçu) ; e) Lauraceae - Ocotea sp. (Louro) ; f) Meliaceae Cedrela sp. (Cedro) ; f) Rosaceae - Licania tomentosa (Benth) Fritsch. (Oiti da Praia) Os PodzólicosVermelho-Amarelos eutróficos, têm vegetação muito 
diversificada desde floresta subperenifólia e subcaducifólia até caatinga. No entanto, os dois perfis ora estudados são característicos de zonas mais secas, e a vegetação a eles associada é a caatinga hiperxerófila.

Os Brunos Não-Cálcicos, os Planossolos Solódicos e o SolonetzSolodizado também ocorrem sob a vegetação de caatinga hiperxerófila. (Brasil, 1973).

Como se pode ver, os solos objeto do estudo em apreço, são na grande maioria associados com a vegetação de caatinga hiperxerófila. Esta se caracteriza pelo alto grau de xerofilismo, com predominância de árvores de porte baixo e pouco densas, presença de espinhos e com uma característica especial de deixar cair as suas folhas na época seca. Entre as espécies vegetais mais comuns podemos citar: Mimosa sp. (unha de gato)Leguminosae; Aspidosperma pyrifolium Mart. (pereiro)-Apocynaceae; Jatropha sp. (pinhão); Cnidoscolus phyllacanthus Hoffm-Euphorbiaceae; Cereus squamosus Guerke (facheiro), Melocactus spp. (coroa de frade)Cactaceae; Bromélia laciniosa Mart. (macambira)-Bromeliaceae e Pilocereus gounellei Weber ( xique-xique)-Cactaceae.

\subsubsection{Geologia e Material Originário}

Os Podzólicos Vermelho-Amarelos da zona fisiográfica de Baturité, onde se encontra a cidade de Guaramiranga, são derivados de saprolitos de gnaisses, referidos ao Pré-Cambriano Indiviso. Os Podzólicos VermelhoAmarelos Eutróficos são derivados de saprolitos de gnaisse do PréCambriano Indiviso e de granito do Pré-Cambriano. Os Brunos Não- 
Cálcicos são originados de saprolitos de gnaisses escuros datados do PreCambriano Indiviso. Os Planossolos Solódicos e o Solonetz-Solodizado são da mesma forma originados de saprolitos de gnaisses do Pré-Cambriano Indiviso. Nestes, incluindo-se também os Bruno Não-Cálcicos, observa-se muito frequentemente uma forte influência de uma delgada camada de material pedimentar na parte superficial do solo. O Pré-Cambriano Indiviso é sob o ponto de vista de extensão o período geológico mais importante, uma vez que ocupa um percentual muito elevado em relação à superficie total do Estado. Por toda a área pertencente a este período há uma predominância absoluta de gnaisses e de migmatitos sobre as demais rochas encontradas. Dentre as mais freqüentes na área em apreço, merecem destaque as seguintes rochas: Gnaisse com biotita, Gnaisse cataclástico, gnaisse cataclástico com biotita e homblenda, gnaisse cataclástico com duas micas e gnaisse quartzoso com duas micas entre outras (Brasil, 1973).

\subsubsection{Relevo e Geomorfologia}

A fig. 3 apresenta um esboço geomorfológico do Estado do Ceará (Souza, 1988). O domínio geomorfológico dos escudos e maciços antigos que engloba os planaltos residuais e as depressões sertanejas onde se localizam os solos ora estudados, constitui o domínio geológico de maior abrangência espacial representando pouco mais de $2 / 3$ do território estadual. A maior parte da área é composta de litologias datadas do Pré-Cambriano, com as unidades morfo-estruturais mostrando uma compartimentação do relevo onde há predominância de extensas áreas aplainadas resultantes de 
processos de pediplanação. Tais formas de relevo exibem reflexos de eventos tectônico-estruturais remotos. Mostram, igualmente, a relação da morfologia com os fatores litológicos e as evidências de flutuações climáticas cenozóicas. O aspecto mais notável é a grande dominância espacial das depressões periféricas derivadas dos processos denudacionais (Souza, 1988).

Segundo Barbosa \& Pinto (1973), a Superfície de Aplainamento Sertaneja forma a depressão semi-árida que circunda a serra da Ibiapaba, chegando até a faixa litorânea. Possui uma topografia levemente ondulada, com afloramentos Pré-Devonianos e fortes influências estruturais. Souza (1975), descreve que a Superficie de Aplainamento Sertaneja se desenvolveu a partir de processos de morfogênese ou mais precisamente em decorrência dos processos de pediplanação influenciados por clima seco. A dissecação é então mínima e o aplainamento é conservado pela semi-aridez atual.

Os Podzólicos Vermelho-Amarelos distróficos e/ou álicos derivados de gnaisses, predominam na zona de Baturité em áreas serranas de relevo forte ondulado e montanhoso e com altitudes variando de 600 a $900 \mathrm{~m}$. Os Podzólicos Vermelho-Amarelos eutróficos têm relevo bastante variado indo desde o plano até o montanhoso, porém, nas áreas de estudo objeto deste trabalho, o relevo regional oscila de suave ondulado a ondulado. Morfoestruturalmente estão associados ao domínio geológico dos Planaltos Residuais e Depressões Sertanejas respectivamente.

Os Brunos Não-Cálcicos estão situados em áreas rebaixadas da Depressão Sertaneja, em unidades geomorfológicas de superfície de 
pediplanação. O relevo varia desde plano até suave ondulado, com predominância do relevo suave ondulado.

O tipo de relevo associado com os Planossolos Solódicos e o Solonetz Solodizado, varia de plano a suave ondulado. Tal como os Planossolos e os Brunos Não-Cálcicos o Solonetz Solodizado está localizado em área de topografia suave e também associado com a Depressão Sertaneja em superficie de pediplanação. As superficies de pediplanação são áreas resultantes de um sistema erosivo intenso, arrasando e modelando grandes extensões sob condições de clima semi-árido. Trata-se de um processo em que predomina o intemperismo físico, que atua desagregando as rochas mais superficiais durante o prolongado período seco, sendo essas massas desagregadas, posteriormente carregadas por enxurradas breves, de alto poder transportador. Geologicamente essas áreas são referidas ao PréCambriano Indiviso (Brasil, 1973). As figuras 4, 5, 6, 7 e 8, mostram os perfis geológico e topográfico das áreas de estudo, com a localização dos pedons investigados. 


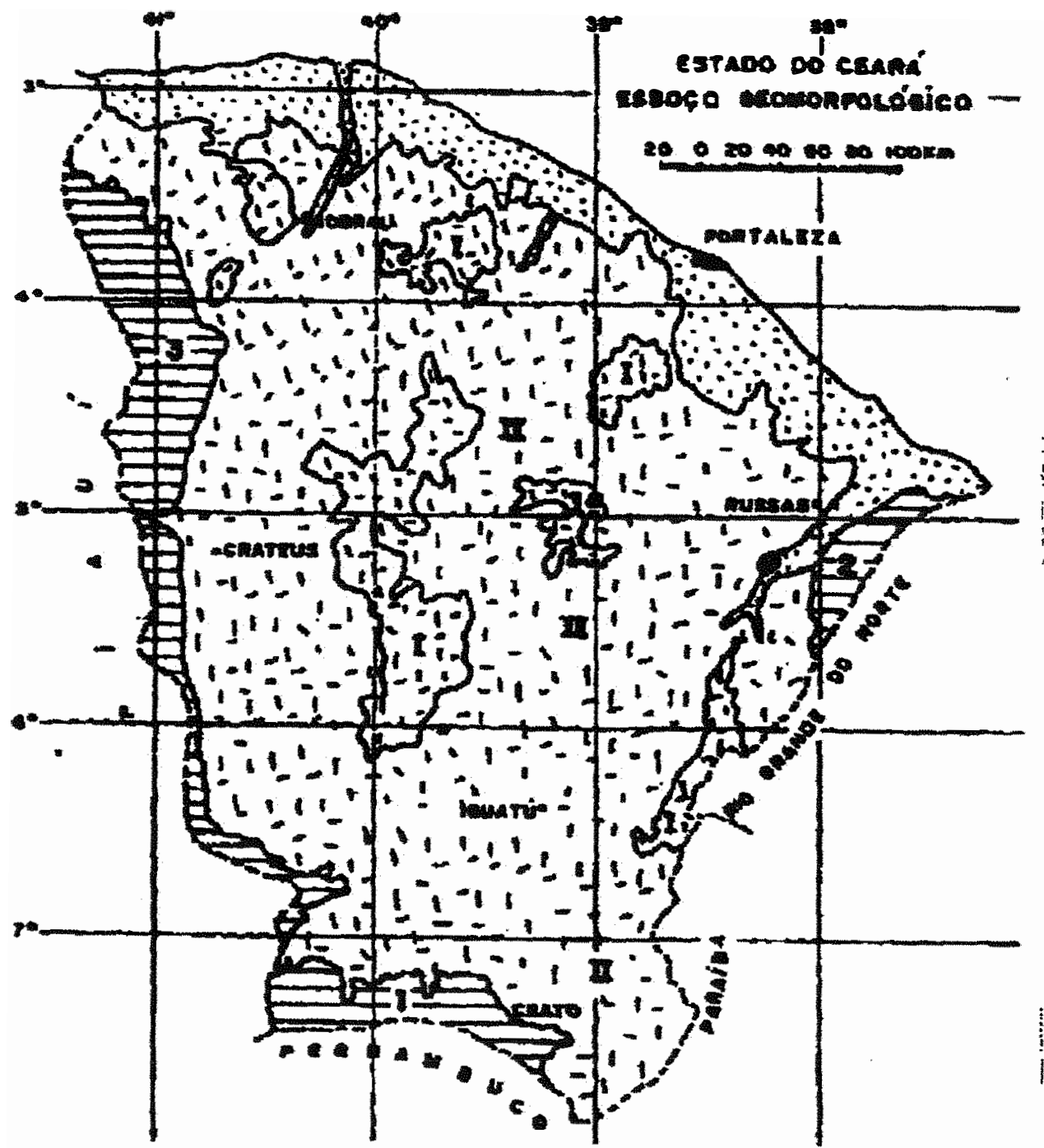

$\therefore$

Domínio dos Depósitos Sedimentares Cenozóicos: Planícies fluviais, Formas Litorâneas e Tabuleiros.

Domínio das Bacias Sedimentares Páleo-Mesozóicas: Chapada do Araripe (1), Chapada do Apodi (2), Planalto da Ibiapaba (3).

:-1 Domínio dos Escudos e Maciços Antigos: Planaltos Residuais (I), Depressões Sertanejas (II).
A - Formas de Acumulação
B - Formas Estruturais
C - Formas Erosivas Dissecadas (I) e Conservadas (II)

ORG: M. J. N. SOUZA

Figura 3 - Esboço geomorfológico do Estado do Ceará. 


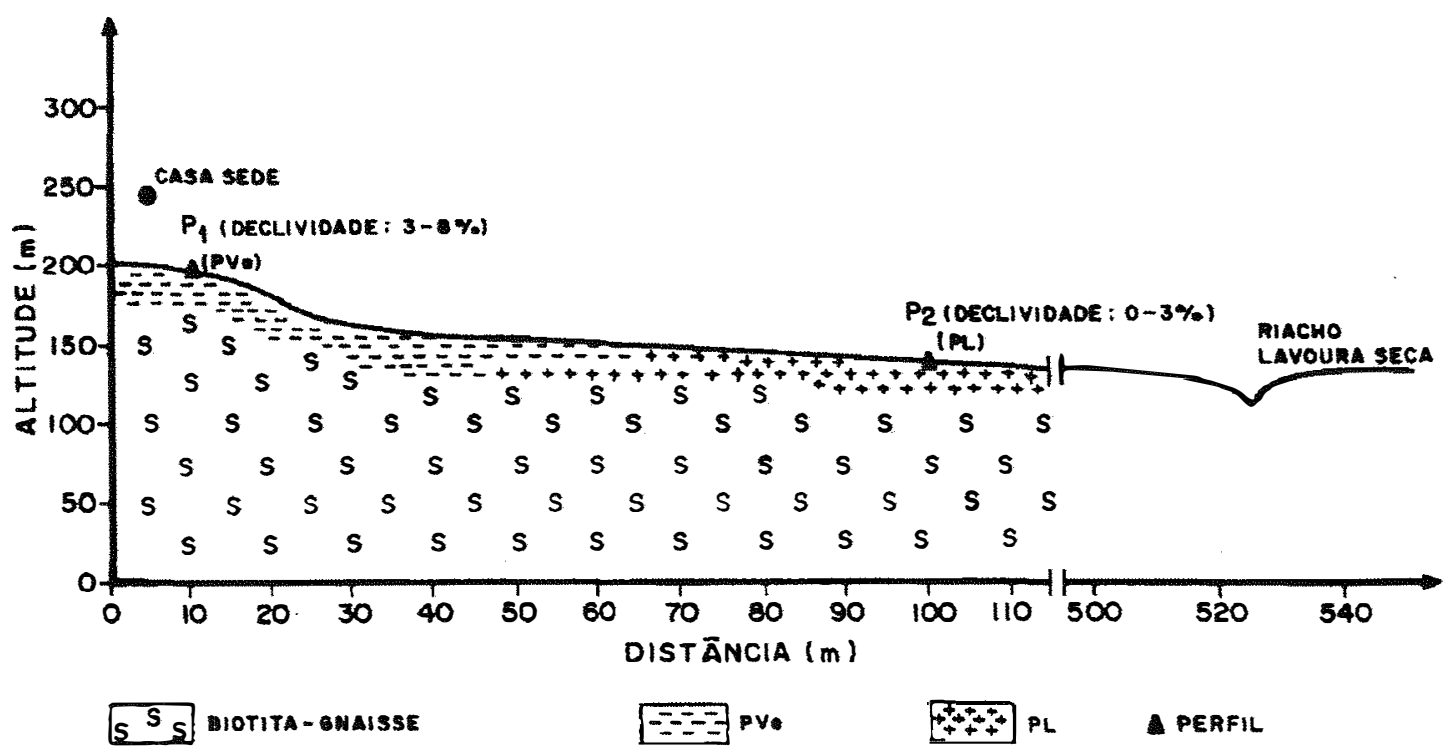

Figura 4 - Perfil geológico e topográfico com a localização dos pedons 1 e 2 no município de Quixadá (Fazenda Lavoura Seca). 


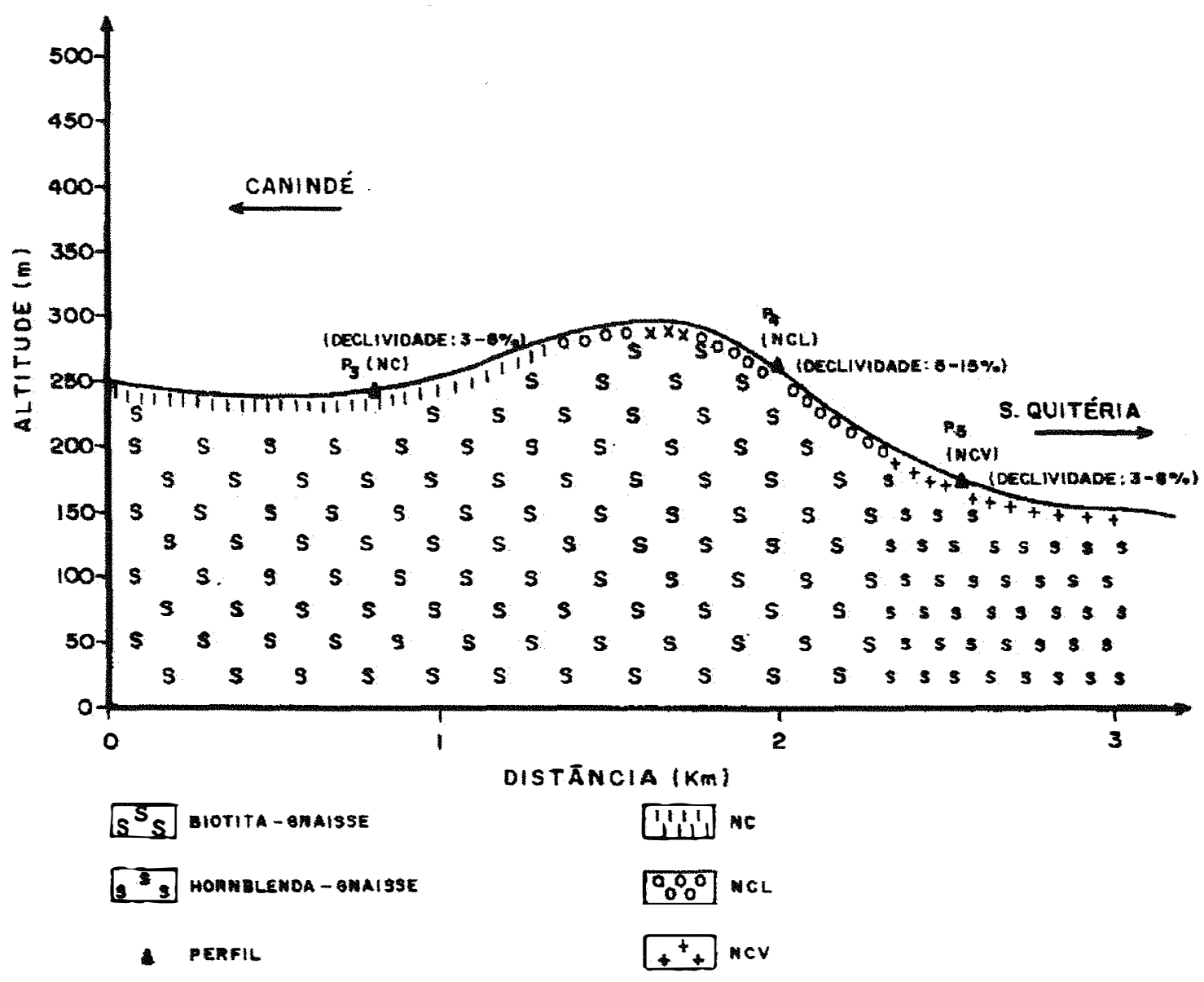

Figura 5 - Perfil geológico e topográfico com a localização dos pedons 3 , 4 e 5 entre as cidades de Canindé e Santa Quitéria. 


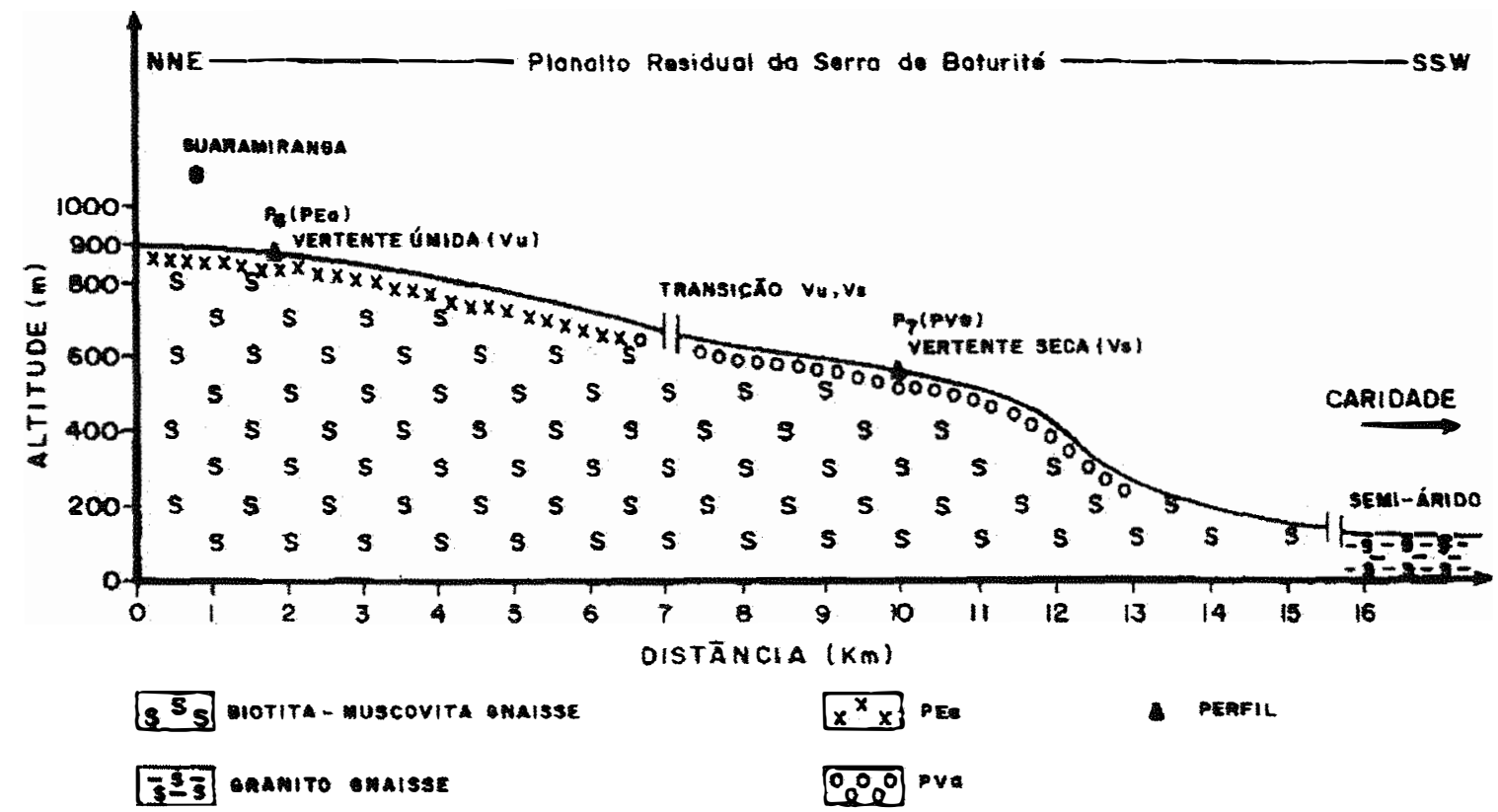

Figura 6 - Perfil geológico e topográfico com a localização dos pedons 6 e 7 nas ver tentes úmida e seca no planalto residual da serra de Baturité, entre as cida des de Guaramiranga e Caridade. 


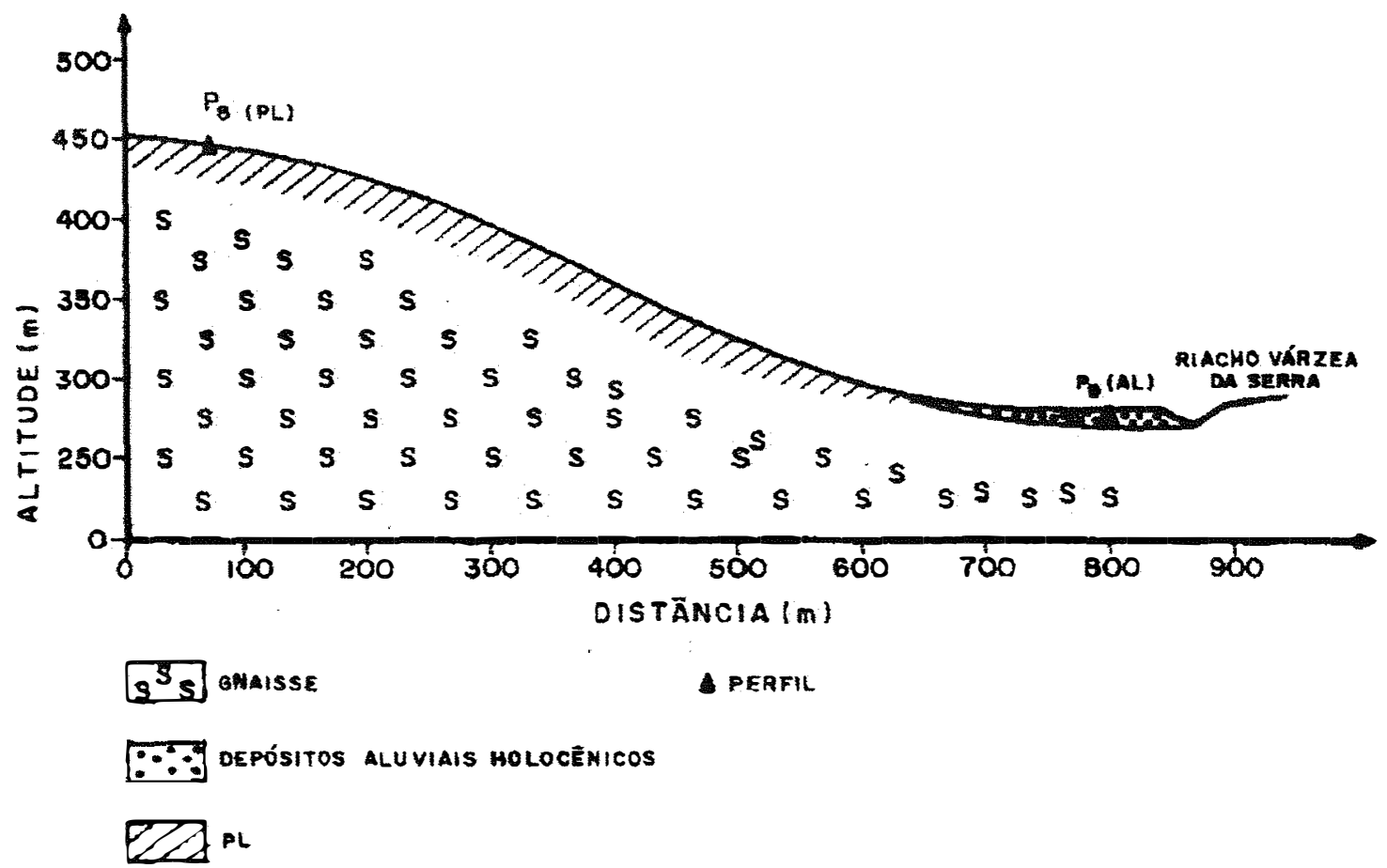

Figura 7 - Perfil geológico e topográfico com a localização dos pedons 8 (PL) e 9 (solo Aluvial) no município de Tauá. 

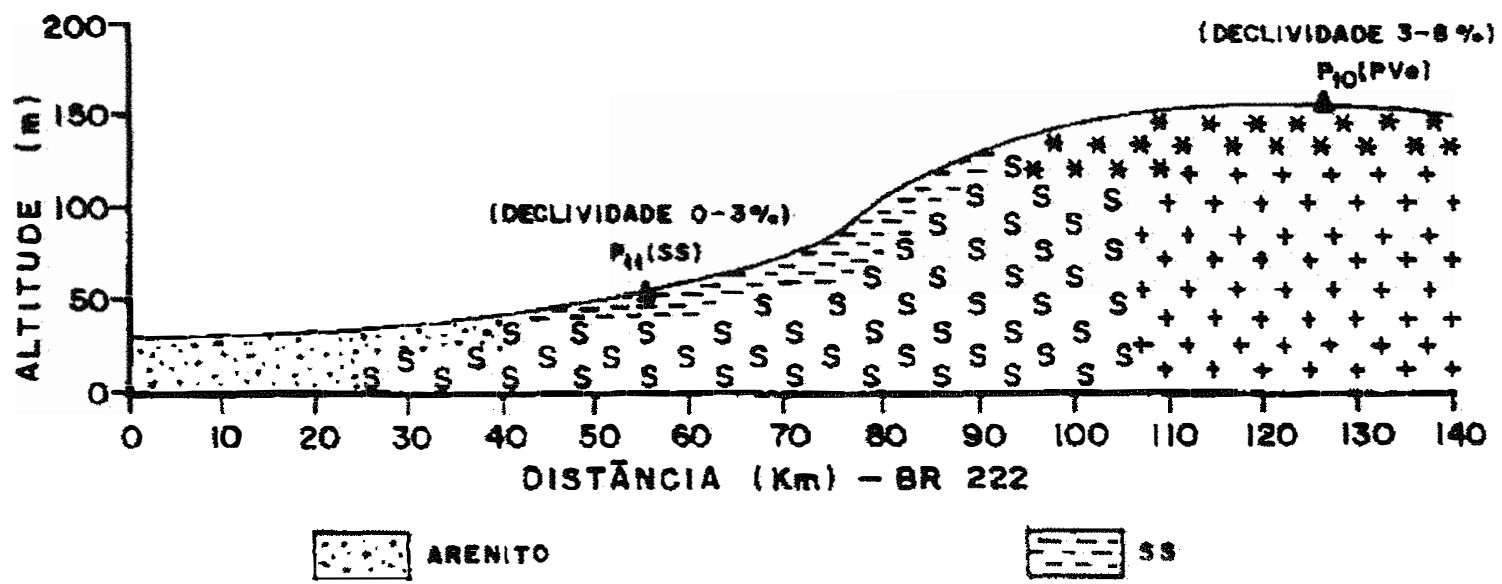

$s^{5}$ s maisse

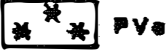

$t+$ eranito

- PERFIL

Figura 8 - Perfil geológico e topográfico com a localização dos perfis 11 e 10, entre as cidades de São Gonçalo do Amarante (Km 55) e Itapagé (Km 125). 


\subsection{Métodos}

\subsubsection{Coleta das amostras}

Foram coletadas amostras em cada horizonte dos perfis. Estes foram descritos de acordo com Lemos \& Santos (1984), com a nomenclatura dos horizontes segundo as normas da Embrapa (1988).

\subsubsection{Preparo das amostras de solo}

As amostras coletadas em cada horizonte, cerca de $3 \mathrm{~kg}$, foram secadas ao ar, antes de serem submetidas a qualquer tipo de tratamento ou análise. Após a secagem foram destorroadas e passadas em peneira de $2 \mathrm{~mm}$ de abertura de malha (T. F. S. A.), e a seguir acondicionadas em sacos de algodão e etiquetadas para serem conservadas e posteriomente usadas durante a pesquisa. Uma parte dessas amostras aproximadamente $1 \mathrm{~kg}$, foi levada ao setor de Ciência do Solo da Universidade de OldenburgAlemanha, onde foram executadas as análises mineralógicas e granulométricas. As análises de rotina, ( água retida a 33 e $1500 \mathrm{kPa}$, carbono orgânico, condutividade elétrica, $\mathrm{pH}$, complexo sortivo, nitrogênio, fósforo assimilável, ataque pelo ácido sulfúrico, etc ), foram conduzidas no laboratório de solos da Universidade Federal do Ceará. 


\subsubsection{Métodos físicos de análise}

\subsubsection{Análise granulométrica}

Foi realizada pelo método da pipeta, Kilmer \& Alexander (1949), utilizando-se $\mathrm{NaOH} \quad 1 \mathrm{~mol} \mathrm{\textrm {L } ^ { - 1 }}$ como dispersante, levando-se em consideração os resultados obtidos por Oliveira (1966). A fração granulométrica areia, foi separada por peneiramento enquanto que o silte e a argila por sedimentação, de acordo com a lei de Stokes. Os separados do solo foram classificados como areia grossa e média $(2000-200 \mu \mathrm{m})$, areia fina $(200-53 \mu \mathrm{m})$, silte grosso $(53-20 \mu \mathrm{m})$, silte fino $(20-2 \mu \mathrm{m})$ e argila $(<2 \mu \mathrm{m})$.

\subsubsection{Argila dispersa em água ou natural}

Foi também obtida pelo método da pipeta, porém sem a utilização de solução química dispersante.

\subsubsection{3 Índice de floculação}

Foi calculado de acordo com a seguinte equação:

$\mathrm{IF}=\%$ argila total $-\%$ argila dispersa em água $\times 100$

$\%$ argila total 


\subsubsection{Densidade de partículas - Dp}

Foi determinada pelo método do picnômetro, usando-se $10 \mathrm{~g}$ de terra fina seca em estufa, água destilada isenta de oxigênio solúvel e picnômetro de $50 \mathrm{ml}$, de acordo com a metodologia de Blake (1965).

\subsubsection{Densidade do solo - Ds}

Foi realizada pelo método do anel volumétrico e também pelo método da balança hidrostática, utilizando-se torrões capeados com parafina aquecida na faixa de $70-80^{\circ} \mathrm{C}$ (Blake, 1965).

\subsubsection{Volume total de poros - VTP}

O volume total de poros foi calculado com os valores de Ds e Dp, através da equação:

$\mathrm{VTP}=(1-\mathrm{Ds} / \mathrm{Dp}) \times 100$

\subsubsection{7 Água retida a 33 e $1500 \mathrm{kPa}$}

Para essas determinações foram usadas a câmara de pressão e as placas porosas respectivas, segundo Richards (1947). 


\subsubsection{Métodos químicos de análise}

\subsubsection{Carbono orgânico}

Foi adotado o método proposto por Tiurim e modificado por Vettori (1969), que consiste na oxidação da matéria orgânica pelo ion bicromato de potássio $0,4 \mathrm{~mol} \mathrm{~L}^{-1}$ e titulação do excesso com sulfato ferroso amoniacal 0,1 mol L-1.

\subsubsection{Condutividade elétrica}

Foi determinada no extrato de saturação, utilizando-se uma ponte salina tipo solubridge com escala de leitura direta em dS.m ${ }^{-1}$ a $25^{\circ} \mathrm{C}$. Antes de serem feitas as leituras das amostras, foi determinada a constante da célula com solução padrão (Richards, 1954).

\subsubsection{3 pH}

Foi determinado na suspensão solo-água na relação 1:2,5 e tempo de contato de uma hora (Vettori, 1969).

\subsubsection{Complexo sortivo}

Através da determinação individual dos cátions trocáveis $\mathrm{Ca}^{++}, \mathrm{Mg}^{++}$, $\mathrm{K}^{+}, \mathrm{Na}^{+}, \mathrm{H}^{+}$, e $\mathrm{Al}^{+++}$, foi obtido o complexo sortivo do solo, segundo a metodologia descrita por Vettori (1969). O cálcio, magnésio e alumínio 
foram extraidos com $\mathrm{KCl} 1 \mathrm{~mol} \mathrm{~L}^{-1}$; potássio e sódio com ácido clorídrico 0,05 $\mathrm{mol} \mathrm{L}^{-1} \mathrm{e}$ hidrogênio + alumínio com acetato de cálcio $1 \mathrm{~mol} \mathrm{~L}^{-1}$ ajustado a $\mathrm{pH} 7,0$. O somatório das bases trocáveis (valor $\mathrm{S}$ ), o valor $\mathrm{T}$ e a percentagem de saturação por bases $(\mathrm{V} \%)$, foram obtidos através das expressões:

$$
\begin{aligned}
& \mathrm{S}=\mathrm{Ca}^{++}+\mathrm{Mg}^{++}+\mathrm{K}^{+}+\mathrm{Na}^{+} \text {em } \mathrm{cmol}_{\mathrm{c}} \cdot \mathrm{kg}^{-1} \text { de solo } \\
& \mathrm{T}=\mathrm{S}+\mathrm{H}^{+}+\mathrm{Al}^{++} \text {em } \text { cmol }_{\mathrm{c}} \cdot \mathrm{kg}^{-1} \text { de solo e } \\
& \mathrm{V} \%=100 \mathrm{~S} / \mathrm{T}
\end{aligned}
$$

\subsubsection{Nitrogênio}

Empregou-se o método de Vettori ( 1969). O N foi determinado por digestão com ácido sulfúrico, catalizado por sulfato de cobre e sulfato de sódio.

\subsubsection{Fósforo assimilável}

Foi extraido com uma solução extratora $0,025 \mathrm{~mol} \mathrm{~L}^{-1} \mathrm{em} \mathrm{H}_{2} \mathrm{SO}_{4}$ e $0,05 \mathrm{~mol}$ $\mathrm{L}^{-1}$ em $\mathrm{HCl}$ (método Norte Carolina) e determinado por fotocolorimetria (Vettori, 1969).

\subsubsection{Ataque pelo ácido sulfúrico}

O ataque com ácido sulfúrico foi realizado conforme Vettori (1969). Foram utilizadas 2,0 g de TFSA, 50ml de $\mathrm{H}_{2} \mathrm{SO}_{4}$ de peso específico $1,47 \mathrm{e}$ fervura sob refluxo durante uma hora, determinando-se os teores de $\mathrm{SiO}_{2}$, 
$\mathrm{Al}_{2} \mathrm{O}_{3}$ e $\mathrm{Fe}_{2} \mathrm{O}_{3}$. De posse dos resultados obtidos, foram calculadas as relações moleculares $\mathrm{SiO}_{2} / \mathrm{Al}_{2} \mathrm{O}_{3}$ ( ki) e $\mathrm{SiO}_{2} / \mathrm{Al}_{2} \mathrm{O}_{3}+\mathrm{Fe}_{2} \mathrm{O}_{3}$ ( kr).

\subsubsection{8 Óxidos de ferro livre}

Foram extraídos com ditionito-citrato-bicarbonato conforme (Jackson, 1969), e determinados por colorimetria.

\subsubsection{Relação $\mathrm{C} / \mathrm{N}$}

Foi calculada em função dos resultados de carbono e nitrogênio.

\subsubsection{Matéria orgânica}

Foi calculada através da expressão: \% M.O. $=\%$ C x 1,724.

\subsubsection{Análises mineralógicas}

\subsubsection{Frações areia e silte}

A mineralogia das frações areia e silte grosso, foi determinada por microscopia ótica de polarização e contraste de fase, por contagem de grãos, usando-se a técnica de contagem de pontos,com base em preparados de areia e silte ( Troger, 1969 e Gebhardt et al. 1967). A estimativa de cada espécie mineral, foi feita em $\%$ de peso da terra fina $(<2 \mathrm{~mm})$. Para uma identificação mais precisa das espécies minerais foram utilizados também 
difratogramas do pó das particulas de areia e silte. Para os feldspatos usou-se também a técnica de coloração com hexacobaltonitrito de sódio

\subsubsection{Frações argila e silte fino}

\subsection{Pré-tratamento e separações para análises das amostras}

A eliminação da matéria orgânica, manganês e sais solúveis, foi feita de acordo com a metodologia descrita por Jackson (1969), tomando-se aproximadamente $20 \mathrm{~g}$ de TFSA e adicionando-se uma solução tamponada a $\mathrm{pH}$ 5,0 de acetato de sódio $1 \mathrm{~mol} \mathrm{~L}^{-1} \mathrm{e}$ água oxigenada.

A remoção dos óxidos de ferro livre foi feita com ditionito-citratobicarbonato de sódio, conforme o método descrito por Mehra \& Jackson (1969). Após a remoção dos óxidos de ferro livre as amostras foram lavadas

tantas vezes quanto necessárias com $\mathrm{NaCl} 0,5 \mathrm{~mol} \mathrm{~L}^{-1}$, visando-se a floculação da argila e sifonação do sobrenadante contendo o ferro complexado.

Estando as amostras isentas de matéria orgânica, manganês e óxidos de ferro livre, foi procedida a separação do silte + argila, das frações mais grosseiras, utilizando-se uma peneira de abertura de malha de $0,053 \mathrm{~mm}$. A suspensão contendo silte mais argila foi levada para tubos de centrífuga e a fração argila $(<2 \mu \mathrm{m})$, separada do silte a 750 r.p.m durante 3 minutos em centrífuga marca internacional número 2. A separação do silte fino do silte grosso também foi efetuada por centrifugação (300 r.p.m durante 3 minutos) 
Uma vez obtidos os preparados de argila e silte fino, alíquotas dos mesmos foram tratadas com $\mathrm{MgCl}_{2} 1 \mathrm{~mol} \mathrm{~L}^{-1}$, segundo recomendações de Jackson (1969). Foram feitas cinco saturações com íons magnésio em centrífuga a 1800 r.p.m durante 5 minutos. $O$ excesso de sal foi eliminado através de lavagens com água destilada, álcool etílico + água destilada e álcool etílico, também sob centrifugação. A eliminação completa dos cloretos foi verificada com $\mathrm{AgNO}_{3}$ a $1 \%$.

Outras alíquotas dos preparados de argila e silte fino foram tratadas com $\mathrm{KCl} 1 \mathrm{~mol} \mathrm{~L}-1$ em vez de $\mathrm{MgCl}_{2}$, (Jackson, 1969). As amostras saturadas com $\mathrm{KCl} 1 \mathrm{~mol} \mathrm{~L}^{-1}$, foram ainda aquecidas a 350 e $550^{\circ} \mathrm{C} . \mathrm{O}$ procedimento de saturação e eliminação do excesso de cloretos foi idêntico ao descrito para $\mathrm{MgCl}_{2}$.

As amostras saturadas com magnésio, ainda úmidas, foram tratadas com etileno glicol e orientadas preferencialmente em lâminas de vidro tipo microscópicas. As saturadas com potássio também foram orientadas preferencialmente.

Após os tratamentos mencionados, as lâminas contendo argila orientada, foram irradiadas com raios- $X$ no intervalo de 2 a $28^{\circ} 2 \theta$, em aparelho Philips micro 1130, com tubo de cobre e filtro de níquel.

As lâminas com silte fino orientado, também foram irradiadas no mesmo aparelho, porém no intervalo $2 \theta$ de 3 a $60^{\circ}$. Nos difratogramas, os valores de $\mathrm{d} / \mathrm{n}$ estão em nm.

Foram também utilizadas na pesquisa lâminas de argila, que receberam os mesmos tratamentos mencionados, porém submetidas à difração de raios - X com orientação ao acaso (provas com pó). 


\subsection{Identificação dos minerais}

Obtidos os difratogramas das lâminas irradiadas, a identificação dos minerais foi feita baseada nos trabalhos de Brindley (1955), Jackson (1969) e Brown (1961), de acordo com os espaçamentos basais mais característicos de cada mineral, ao serem submetidos aos tratamentos antes mencionados.

A avaliação semiquantitativa na fração argila dos minerais identificados, foi feita com base na intensidade relativa dos picos característicos de cada mineral, nas lâminas de pó com orientação ao acaso, mediante cálculo de suas áreas ( John et al. 1954).

As frações da maior parte dos solos estudados, foram ainda examinadas por microscopia eletrônica de varredura usando-se lâminas e torrões em um aparelho REM Zeiss 940, para obtenção de informações complementares qualitativas e/ou quantitativas das alterações mineralógicas, fornecidas pelos métodos de microscopia ótica e difração de raios X. As amostras antes de serem observadas no microscópio eletrônico foram metalizadas com uma finíssima película de ouro. Os eletrons incidentes sobre as amostras observadas, proporcionaram a reflexão de eletrons secundários que reproduziram em um monitor as imagens dos constituintes mineralógicos com um alto nível de resolução. 


\section{RESULTADOS E DISCUSSĀO}

\subsection{Atributos morfológicos, fisicos e químicos}

As tabelas 2 a 9 e o (anexo A), apresentam os principais atributos fisicos e químicos e as descrições macromorfológicas dos onze perfis de solos estudados, que excetuando-se o solo aluvial, se enquadram espacialmente, entre as classes de solos mais representativas do Estado do Ceará, concordando com o descrito em (Brasil, 1973).

A maioria dos pedons encontram-se dispostos na paisagem em topossequências (perfis 1 e 2; 3,4 e $5 ; 6$ e 7 e 8 e 9), como pode ser observado nas figuras 4 a 7 (pgs. 50 a 54). Os pedons 10 e 11 (figura 8), estão situados a uma distância relativamente longa $(70 \mathrm{~km})$, na BR - 222, sendo originados de rochas distintas e localizados em zonas fisiográficas diferentes (tabela 1 e figura 2), porém o perfil 10 já situa-se na transição litoral - semi-árido.

Todos os pedons correspondem a perfil completo, com sequência A, $\mathrm{B}, \mathrm{C}$ ou $\mathrm{A}, \mathrm{E}, \mathrm{B}, \mathrm{C}$ de horizontes e com exceção do perfil 1 que tem o granito como rocha subjacente, todos os demais têm o gnaisse como substrato rochoso, com ambas as rochas referidas ao Pré-Cambriano Indiviso. Observações de campo, relatos da literatura e estudos da distribuição do mineral quartzo com a profundidade, convergem no sentido 


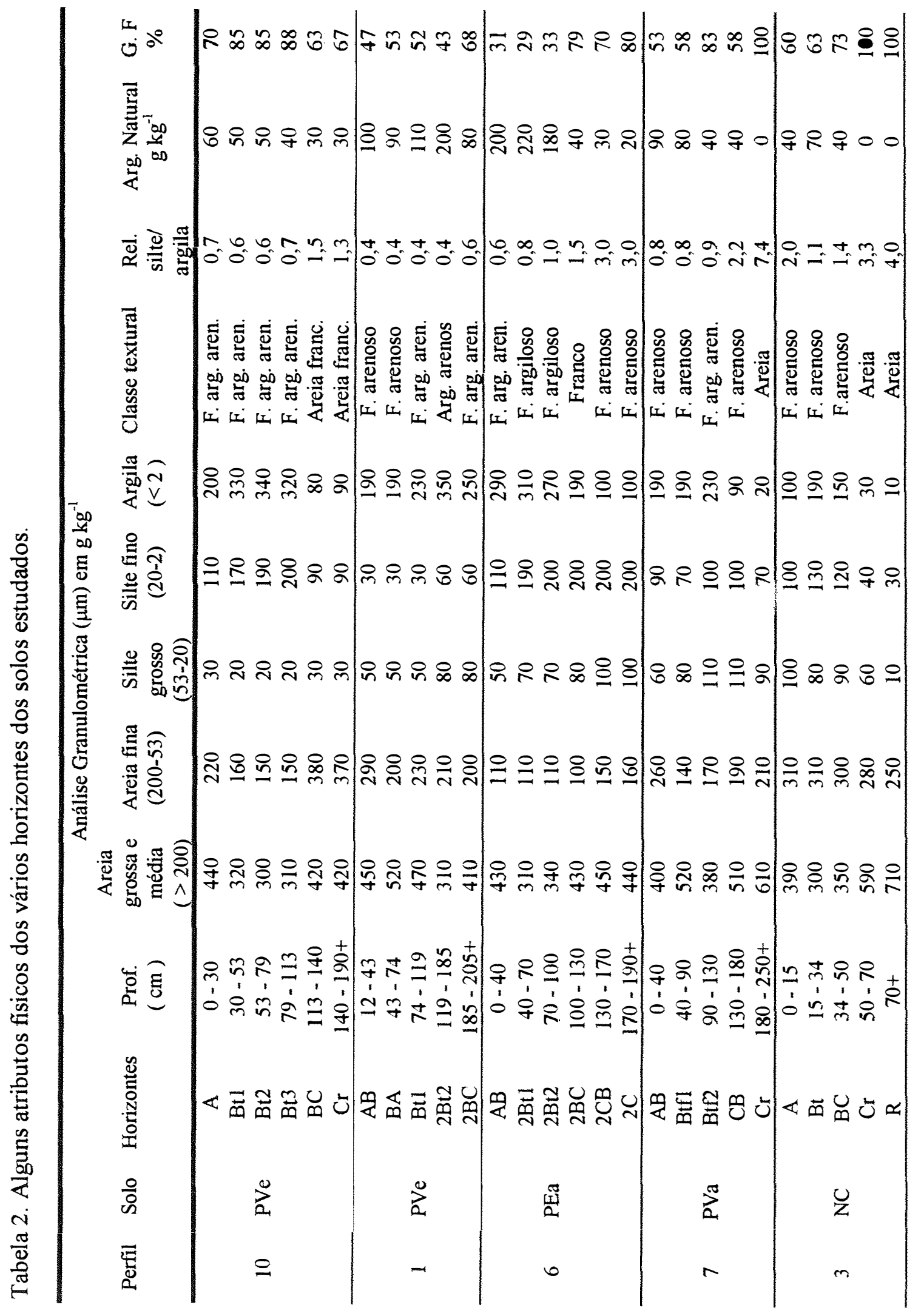




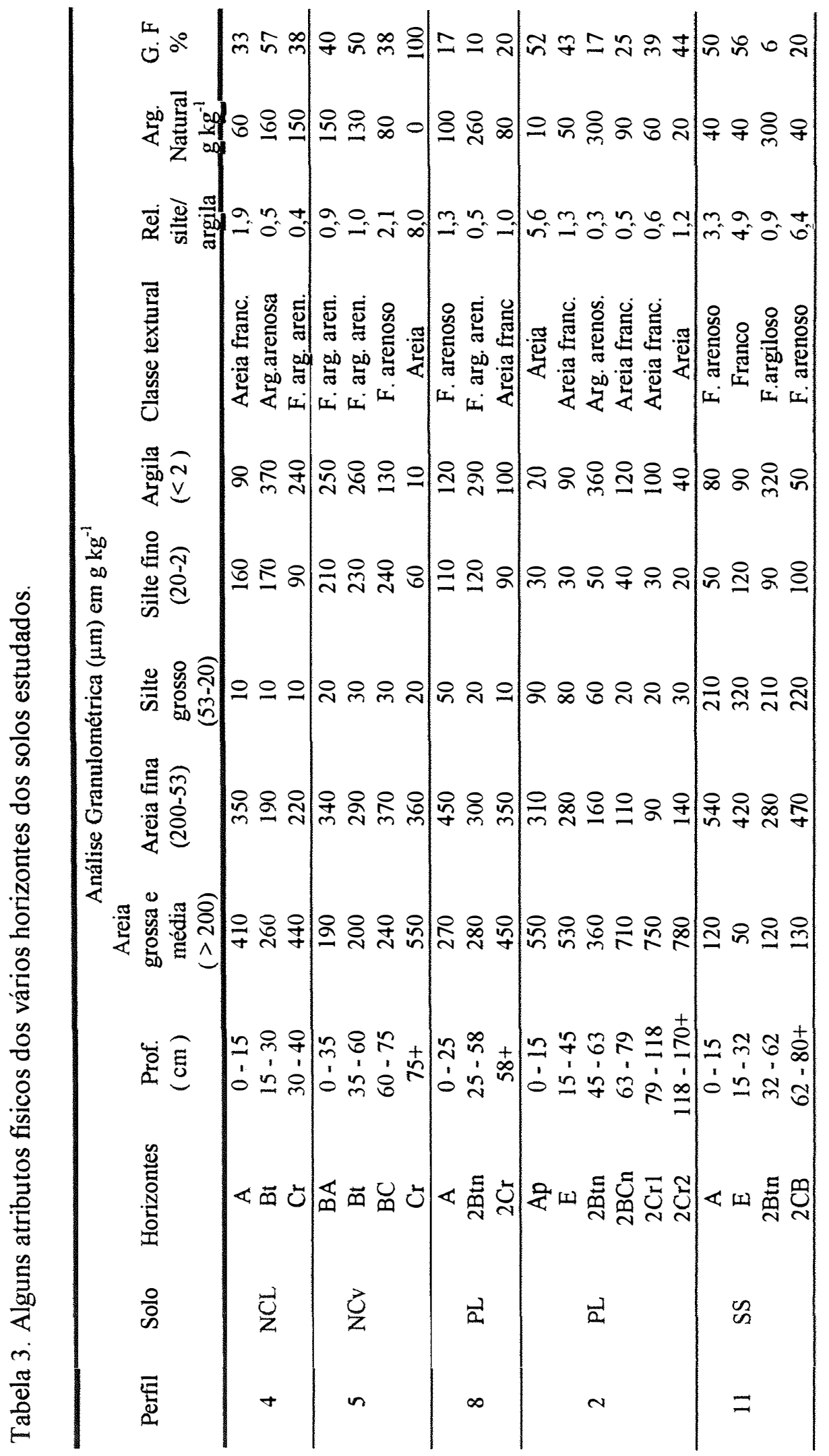


Tabela 4. Valores de densidade de partículas (Dp), densidade do solo (Ds), volume total de poros (VTP), água retida a 33 e $1500 \mathrm{kPa}$ e água útil nos horizontes dos perfis estudados.

\begin{tabular}{|c|c|c|c|c|c|c|c|c|}
\hline Perfil & Solo & Horizontes & Prof. (cm) & $\begin{array}{c}\mathrm{Dp} \\
\mathrm{kg} \mathrm{dm^{-3 }}\end{array}$ & $\begin{array}{c}\text { Ds } \\
\mathrm{kg} \mathrm{dm}^{-3}\end{array}$ & $\begin{array}{c}\text { VTP } \\
\mathrm{dm}^{3} \mathrm{dm}^{-3}\end{array}$ & $\begin{array}{c}\text { Umidade }\left(\mathrm{m}^{3} \mathrm{~m}^{-3}\right) \\
\mathrm{kPa} \\
331500 \\
\end{array}$ & $\begin{array}{c}\text { Água } \\
\text { Útil } \\
\mathrm{m}^{3} \mathrm{~m}^{-3} \\
\end{array}$ \\
\hline \multirow{6}{*}{10} & \multirow{6}{*}{ PVe } & A & $0-30$ & 2,59 & 1,52 & 0,41 & $0,130,03$ & 0,10 \\
\hline & & Bt1 & $30=53$ & 2,63 & 1,53 & 0,42 & $0,160,11$ & 0,05 \\
\hline & & $\mathrm{Bt} 2$ & $53-79$ & 2,62 & 1,54 & 0,41 & $0,160,10$ & 0,06 \\
\hline & & $\mathrm{Bt} 3$ & $79-113$ & 2,62 & 1,56 & 0,40 & $0,17 \quad 0,10$ & 0,07 \\
\hline & & $\mathrm{BC}$ & $113-140$ & 2,63 & 1,57 & 0,40 & $\begin{array}{lll}0,20 & 0,07\end{array}$ & 0,13 \\
\hline & & $\mathrm{Cr}$ & $140-190+$ & 2,63 & 1,56 & 0,41 & - & - \\
\hline \multirow{5}{*}{1} & \multirow{5}{*}{ PVe } & $\mathrm{AB}$ & $12-43$ & 2,62 & 1,60 & 0,39 & $0,15 \quad 0,07$ & 0,08 \\
\hline & & BA & $43-74$ & 2,62 & 1,61 & 0,39 & $0,15 \quad 0,07$ & 0,08 \\
\hline & & Btl & $74-119$ & 2,63 & 1,59 & 0,40 & $0,160,08$ & 0,08 \\
\hline & & $2 \mathrm{Bt} 2$ & $119-185$ & 2,64 & 1,58 & 0,40 & $0,21 \quad 0,13$ & 0,08 \\
\hline & & $2 \mathrm{BC}$ & $185-205+$ & 2,64 & 1,58 & 0,40 & $0,16 \quad 0,10$ & 0,06 \\
\hline \multirow{6}{*}{6} & \multirow{6}{*}{$\mathrm{PEa}$} & $\overline{A B}$ & $0-40$ & 2,55 & 1,46 & 0,43 & $0,24 \quad 0,14$ & 0,10 \\
\hline & & $2 \mathrm{BtI}$ & $40-70$ & 2,63 & 1,55 & 0,41 & $\begin{array}{lll}0,27 & 0,14\end{array}$ & 0,13 \\
\hline & & $2 \mathrm{Bt} 2$ & $70-100$ & 2,62 & 1,56 & 0,40 & $0,290,13$ & 0,16 \\
\hline & & $2 \mathrm{BC}$ & $100-130$ & 2,63 & 1,57 & 0,40 & $0,290,11$ & 0,18 \\
\hline & & $2 \mathrm{CB}$ & $130-170$ & 2,65 & 1,56 & 0,41 & $0,30 \quad 0,12$ & 0,18 \\
\hline & & $2 \mathrm{C}$ & $170-190+$ & 2,65 & 1,58 & 0,40 & $0,290,11$ & 0,18 \\
\hline \multirow{5}{*}{7} & \multirow{5}{*}{$\mathrm{PVa}$} & $\overline{A B}$ & $0-40$ & 2,63 & 1,55 & 0,41 & $0,23 \quad 0,12$ & 0,11 \\
\hline & & Btfl & $40-90$ & 2,63 & 1,56 & 0,41 & $0,26 \quad 0,13$ & 0,13 \\
\hline & & Btf2 & $90-130$ & 2,64 & 1,56 & 0,41 & $0,26 \quad 0,12$ & 0,14 \\
\hline & & $\mathrm{CB}$ & $130-180$ & 2,65 & 1,58 & 0,40 & $0,260,10$ & 0,16 \\
\hline & & $\mathrm{Cr}$ & $180-250+$ & 2,64 & 1,57 & 0,41 & - & - \\
\hline \multirow{5}{*}{3} & \multirow{5}{*}{$\mathrm{NC}$} & $\mathrm{A}$ & $0-15$ & 2,60 & 1,59 & 0,39 & $0,160,05$ & 0,11 \\
\hline & & $\mathrm{Bt}$ & $15-34$ & 2,64 & 1,56 & 0,41 & $\begin{array}{lll}0,17 & 0,08\end{array}$ & 0,09 \\
\hline & & $\mathrm{BC}$ & $34-50$ & 2,64 & 1,55 & 0,41 & $0,18 \quad 0,08$ & 0,10 \\
\hline & & $\mathrm{Cr}$ & $50-70$ & 2,65 & 1,57 & 0,41 & $0,08 \quad 0,02$ & 0,06 \\
\hline & & $\mathrm{R}$ & $70+$ & - & - & - & - & - \\
\hline
\end{tabular}


Tabela 5. Valores de densidade de partículas (Dp), densidade do solo (Ds), volume total de poros (VTP), água retida a 33 e $1500 \mathrm{kPa}$ e água útil nos horizontes dos perfis estudados.

\begin{tabular}{|c|c|c|c|c|c|c|c|c|}
\hline Perfil & Solo & Horizontes & Prof. $(\mathrm{cm})$ & $\underset{\mathrm{kg} \mathrm{dm}^{-3}}{\mathrm{Dp}}$ & $\begin{array}{c}\text { Ds } \\
\mathrm{kg} \mathrm{dm}^{-3}\end{array}$ & $\begin{array}{c}\text { VTP } \\
\mathrm{dm}^{3} \mathrm{dm}^{-3}\end{array}$ & $\begin{array}{c}\operatorname{Umidade}\left(\mathrm{m}^{3} \mathrm{~m}^{-3}\right) \\
\mathrm{kPa} \\
331500\end{array}$ & $\begin{array}{l}\text { Água } \\
\text { Útil } \\
\mathrm{m}^{3} \mathrm{~m}^{-3}\end{array}$ \\
\hline \multirow{3}{*}{4} & \multirow{3}{*}{ NCL } & A & $0-15$ & 2,63 & 1,60 & 0,39 & $0,130,04$ & 0,09 \\
\hline & & $\mathrm{Bt}$ & $15-30$ & 2,65 & 1,56 & 0,41 & $0,320,11$ & 0,21 \\
\hline & & $\mathrm{Cr}$ & $30-40$ & 2,65 & 1,58 & 0,40 & - & - \\
\hline \multirow{4}{*}{5} & \multirow{4}{*}{$\mathrm{NCv}$} & $\mathrm{BA}$ & $0-35$ & 2,60 & 1,59 & 0,39 & $0,20 \quad 0,10$ & 0,10 \\
\hline & & $\mathrm{Bt}$ & $35-60$ & 2,64 & 1,57 & 0,41 & $0,220,11$ & 0,11 \\
\hline & & $\mathrm{BC}$ & $60-75$ & 2,64 & 1,56 & 0,41 & $0,23 \quad 0,09$ & 0,14 \\
\hline & & $\mathrm{Cr}$ & $75+$ & 2,66 & 1,57 & 0,41 & - & - \\
\hline \multirow{3}{*}{8} & \multirow{3}{*}{ PL } & $\mathrm{A}$ & $0-25$ & 2,66 & 1,58 & 0,41 & $0,09 \quad 0,04$ & 0,05 \\
\hline & & $2 \mathrm{Btn}$ & $25-58$ & 2,65 & 1,68 & 0,37 & $0,23 \quad 0,11$ & 0,12 \\
\hline & & $2 \mathrm{Cr}$ & $58+$ & 2,65 & 1,62 & 0,39 & - & - \\
\hline \multirow{6}{*}{2} & \multirow{6}{*}{ PL } & Ap & $0-15$ & 2,64 & 1,57 & 0,41 & $0,05 \quad 0,01$ & 0,04 \\
\hline & & $\mathrm{E}$ & $15-45$ & 2,64 & 1,56 & 0,41 & $0,09 \quad 0,03$ & 0,06 \\
\hline & & 2Btn & $45-63$ & 2,64 & 1,69 & 0,36 & $0,24 \quad 0,13$ & 0,11 \\
\hline & & $2 \mathrm{BCn}$ & $63-79$ & 2,64 & 1,65 & 0,38 & $0,24 \quad 0,13$ & 0,11 \\
\hline & & $2 \mathrm{Crl}$ & $79-118$ & 2,65 & 1,62 & 0,39 & $0,18 \quad 0,10$ & 0,08 \\
\hline & & $2 \mathrm{Cr} 2$ & $118-170+$ & 2,63 & 1,61 & 0,39 & - & - \\
\hline \multirow{4}{*}{11} & \multirow{4}{*}{ SS } & A & $0-15$ & 2,61 & 1,56 & 0,40 & $\begin{array}{lll}0,09 & 0,02\end{array}$ & 0,07 \\
\hline & & $\mathrm{E}$ & $15-32$ & 2,65 & 1,56 & 0,41 & $0,10 \quad 0,03$ & 0,07 \\
\hline & & $2 \mathrm{Btn}$ & $32-62$ & 2,64 & 1,67 & 0,37 & $0,190,09$ & 0,10 \\
\hline & & $2 \mathrm{CB}$ & $62-80+$ & 2,65 & 1,64 & 0,38 & - & - \\
\hline
\end{tabular}




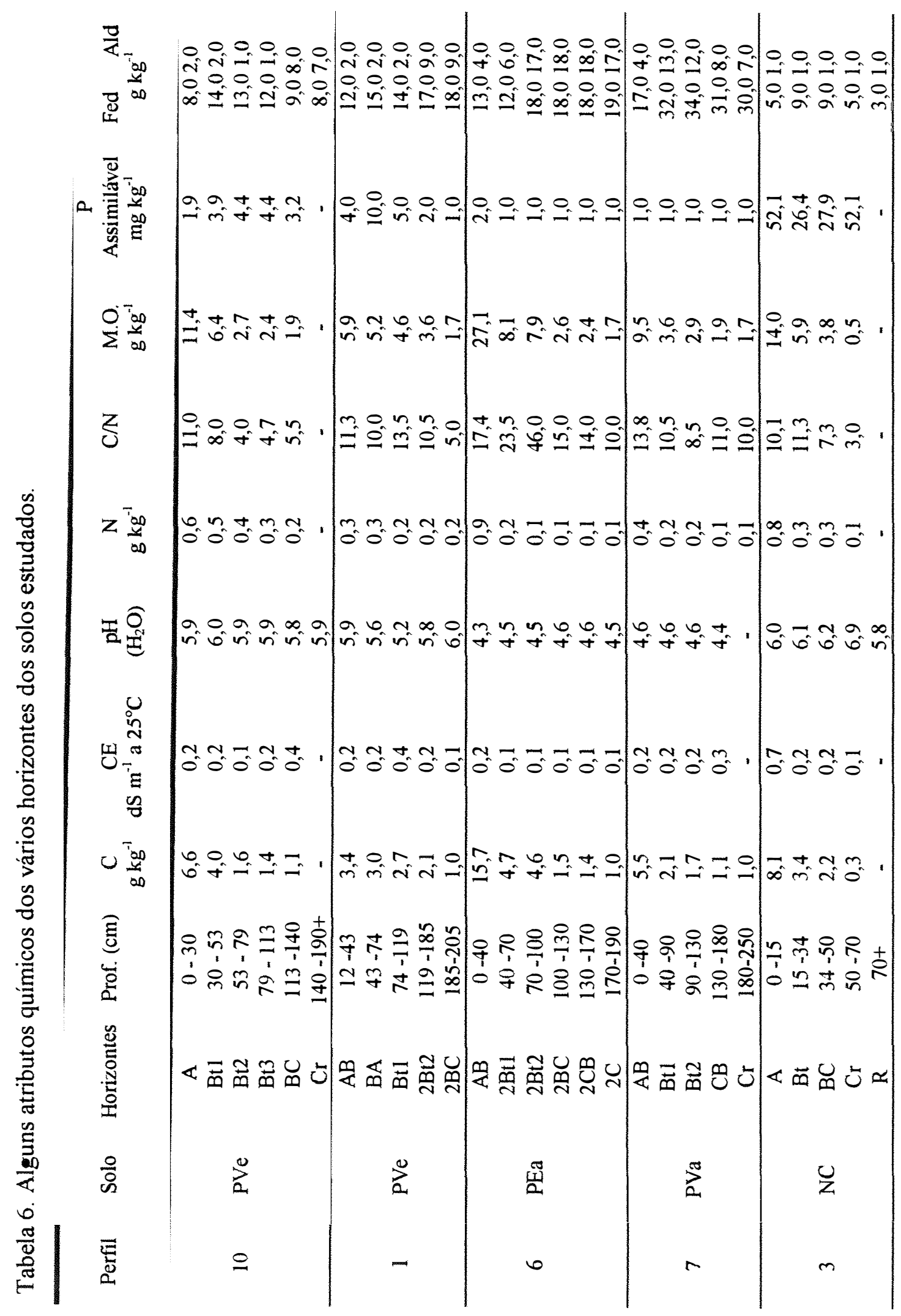




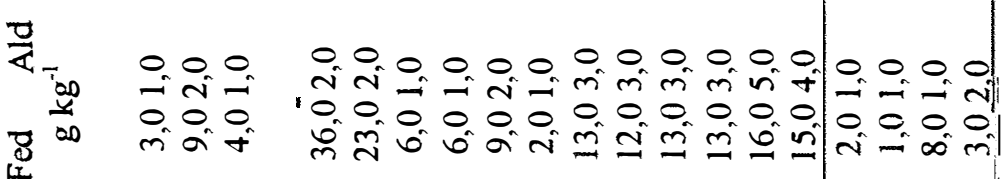

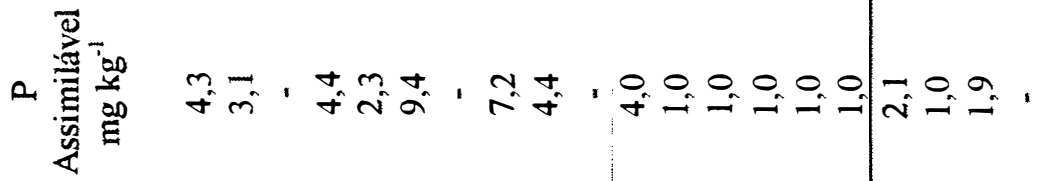

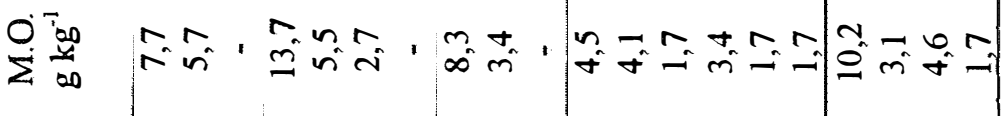

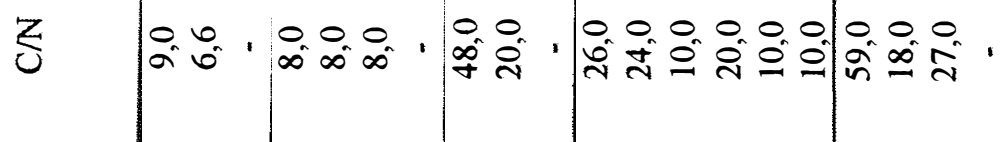

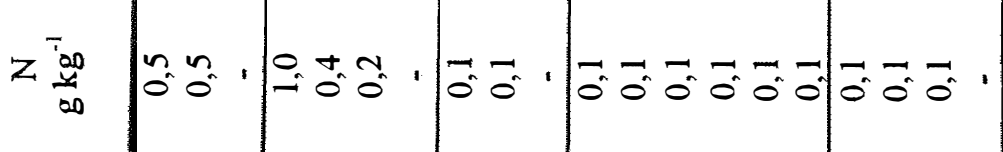

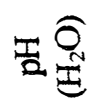
की

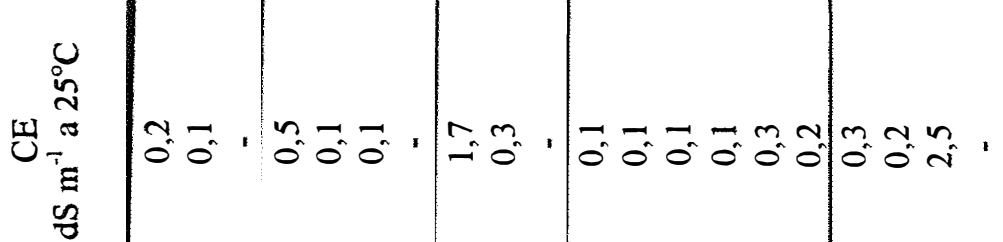

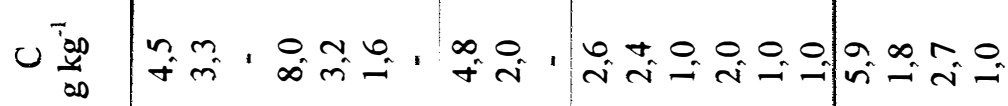
产 유웅유

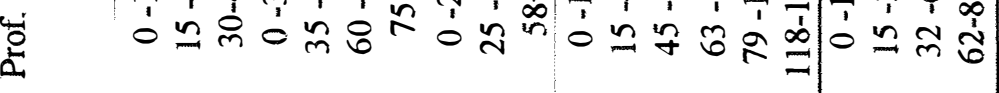

N 


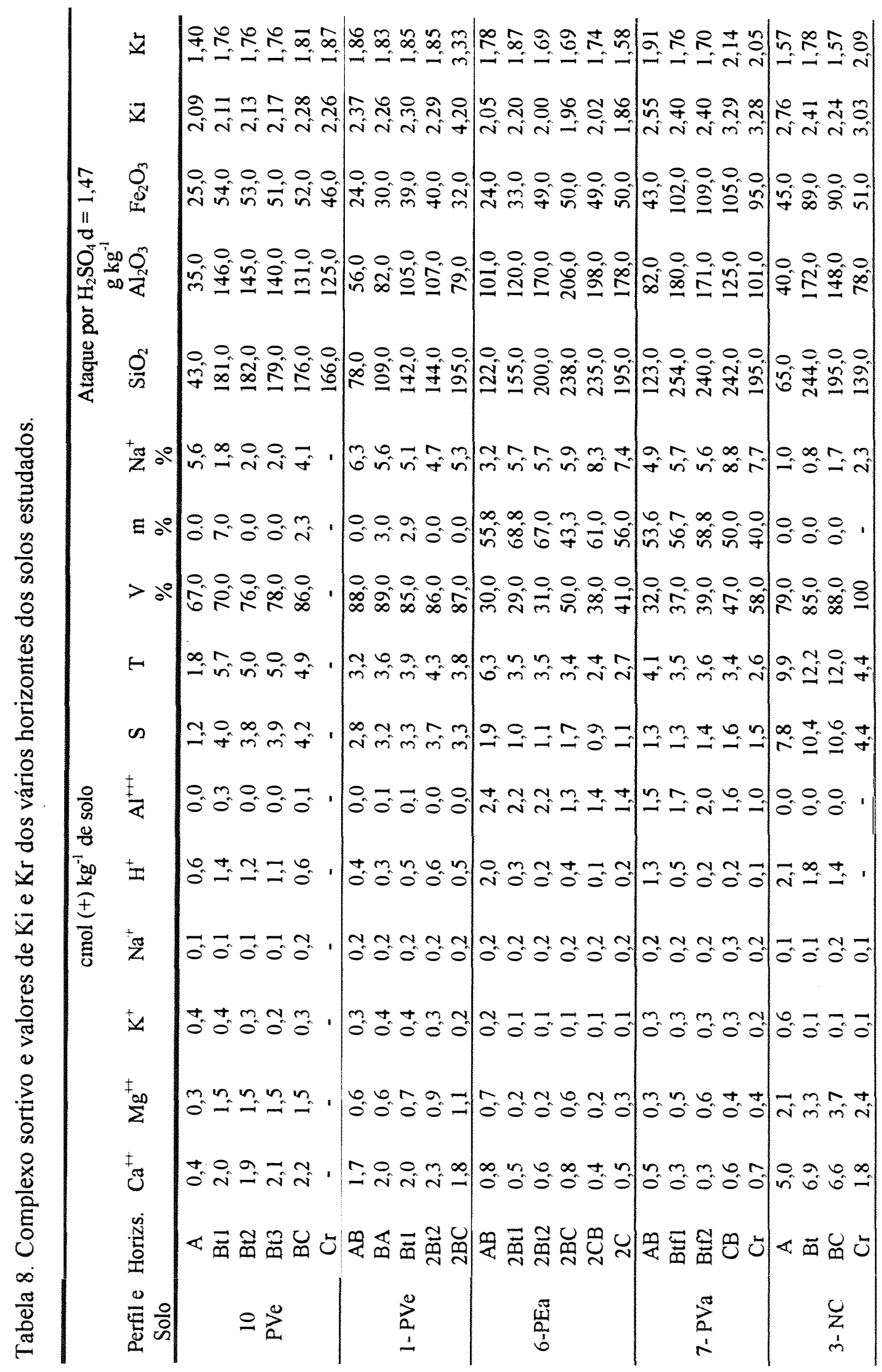




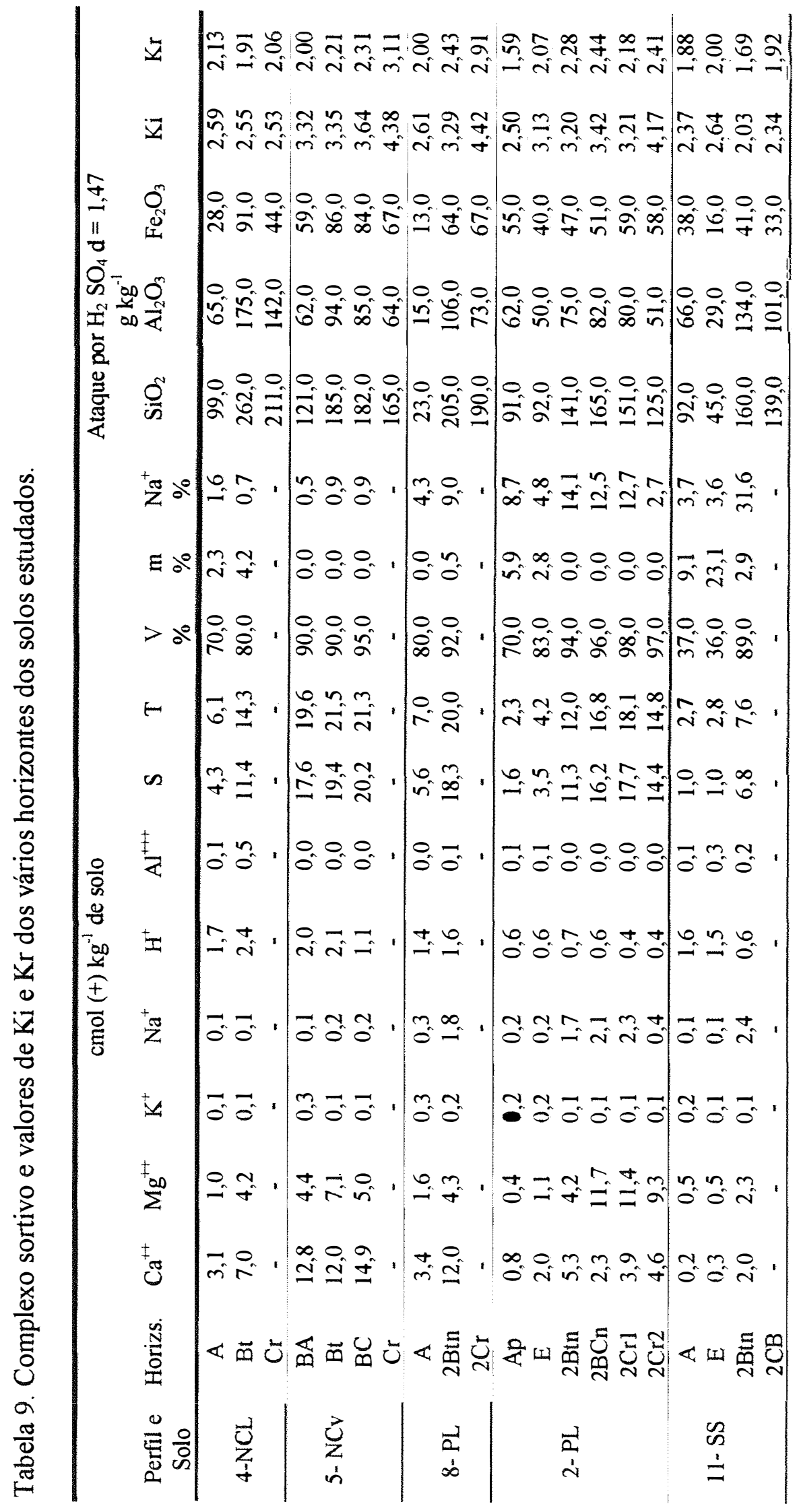


de apoiar a hipótese de que os solos em apreço, são autóctones ou pseudoautóctones, como será discutido posteriormente. Alguns perfis $(1,6,7$ e 5), mostram evidências de intenso processo erosivo, com o horizonte superficial parcialmente removido. Os atributos morfológicos, físicos e químicos dos pedons associados com as suas classificações no sistema brasileiro, estão de acordo com o proposto em (Brasil, 1973; Camargo et al., 1987; Oliveira et al., 1992 e Jacomine, 1996).

Com o objetivo de facilitar a identificação e discussão dos resultados obtidos, os solos foram denominados de acordo com nomes sugestivos dos locais:
(a) Solos de Quixadá;
(b) Solos de Canindé;
(c) Solos de Guaramiranga;
(d) Solos de Tauá
(e) Solos da BR-222

\subsubsection{Solos de Quixadá}

Compreende dois perfis (1 e 2), localizados no município de Quixadá, na fazenda Lavoura Seca, pertencente à Universidade Federal do Ceará. Esses solos (PVe e PL), são associações típicas da região, com o Podzólico Vermelho Amarelo ocupando posições de topo e encosta e o Planossolo Solódico as partes mais baixas da paisagem (figura 4, pg. 50). Observandose as descrições morfológicas (anexo A), verifica-se que a profundidade do "solum" varia de $205 \mathrm{~cm}$ no PVe (perfil 1), a $79 \mathrm{~cm}$ no PL (perfil 2). O 
perfil 1 apresenta maior erosão do que o perfil 2, mostrando o horizonte superficial parcialmente truncado. A diferenciação de cores entre os dois perfis resulta de suas posições na paisagem, condicionadas por suas drenagens internas. A cor avermelhada no horizonte Bt do perfil 1 de boa drenagem, é substituida por uma coloração variegada nesse mesmo horizonte no perfil 2, que tem drenagem imperfeita e localiza-se na zona de maior acumulação da topossequência. A estrutura é relativamente bem desenvolvida ao longo de todo o perfil do PVe em blocos angulares e/ou subangulares, com grau fraca no A e moderada e forte nos demais horizontes. Por outro lado o PL apresenta-se em grãos individuais nos horizontes A e E e em blocos subangulares forte a moderada em 2Btn e 2BCn. A consistência no perfil 1 é muito duro no estado seco variando de friável a firme quando úmido e de não plástico a não pegajoso a plástico e pegajoso quando molhado, com o aumento da profundidade. O perfil 2 varia de solto a extremamente duro quando seco, de solto a muito firme quando úmido e de não pástico a não pegajoso a muito plástico e muito pegajoso quando molhado nos diversos horizontes. A presença de superficies brilhantes e cerosas (cerosidade), formando revestimentos nas unidades estruturais do Bt são evidentes no perfil 1, não se verificando tal feição morfológica no mesmo horizonte do perfil 2.

Alguns atributos físicos e químicos dos perfis estão apresentados nas tabelas $2,3,4,5,6,7,8$ e 9 . O perfil 1 de textura média não mostra acentuado aumento de argila em profundidade (gradiente textural $=1,5$ ), mas considerando a erosão laminar severa no horizonte superficial e a presença de cerosidade detectada no campo, o horizonte B desse solo foi qualificado 
como B textural. O perfil 2 (PL), com textura arenosa/argilosa tem um gradiente elevado, da ordem de 6,5 concordando com Oliveira et al. (1992) e Camargo et al. (1987). A relação silte/argila maior em quase todos os horizontes do perfil 2 em relação ao perfil 1, traduz de certa forma, uma maior intemperização do segundo solo quando comparado ao primeiro. Os valores de densidade do solo e volume total de poros que se refletem na água retida a 33 e $1500 \mathrm{kPa}$ e água disponível, mostram diferenças principalmente no horizonte B desses solos. O PL tem maiores Ds e menores VTP quando confrontado com o PVe. A densidade de partículas tem valores muito semelhantes nos dois solos.

O complexo sortivo, os valores de ki e $\mathrm{kr}$ e os principais atributos químicos, também diferem nos dois perfis, com a influência da posição no relevo, tendo forte influência. O perfil 1 apresenta argila de atividade baixa enquanto que o perfil 2 tem argila de atividade alta e alta saturação por bases embora ambos os solos mostrem caráter eutrófico, devido a baixa acidez

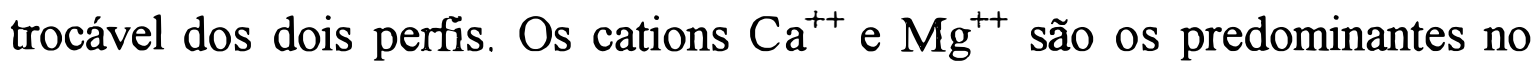
complexo de troca dos perfis, porém o teor de $\mathrm{Na}^{+}$relativamente alto nos horizontes $2 \mathrm{Btn}, 2 \mathrm{BCn}$ e $2 \mathrm{Cr} 1$ do perfil 2, variando de 12,5 a $14,1 \%$, conferem ao PL o caráter solódico. $\mathrm{O} \mathrm{K}^{+}$em ambos os perfis é a base trocável em menor teor excetuando o $\mathrm{Na}^{+}$no perfil 1 . O pH varia de 5,2 a 6,0 no PVe e de 5,3 a 7,1 no PL, refletindo nesse último os mais altos teores de sódio trocável. O ki e o kr são mais elevados no PL do que no PVe, estando de acordo com a mineralogia das frações mais finas, condicionado pela drenagem interna, como será discutido posteriomente. Carbono e matéria orgânica são baixos nos dois solos e decrescem com a profundidade, 
o que já era esperado em função do ambiente semi-árido onde esta localizada a topossequência. A condutividade elétrica é baixa nos dois perfis, não caracterizando nenhum processo de salinização.

\subsubsection{Solos de Canindé}

Está constituida pelos perfis $3(\mathrm{NC}), 4(\mathrm{NCL})$ e $5(\mathrm{NCv})$ (figura 5, pg. 51), localizados entre as cidades de Canindé e Santa Quitéria. Observandose as descrições morfológicas (anexo A), verifica-se que os três perfis variam de moderadamente profundos a rasos, com sequência $\mathrm{A}, \mathrm{Bt}$ e $\mathrm{C}$ de horizontes, embora no perfil 5 o horizonte A esteja praticamente truncado. É comum a presença de rachaduras na superficie e interior deste perfil, caracterizando o caráter vértico. A drenagem varia de boa nos perfis 3 e 4 a moderada no perfil 5. O "solum" nos três pedons tem uma profundidade de 30 a $60 \mathrm{~cm}$, com a maior espessura sendo encontrada no $\mathrm{NCV}$. A cor do horizonte A nos três perfis, mostra matizes de $10 \mathrm{YR}$ a $2.5 \mathrm{YR}$ com valores de 3 a 5 e croma 4. A textura varia de areia franca a franco argilo arenoso e a estrutura é do tipo moderada média em blocos angulares e/ou subangulares. A consistência quando seco é ligeiramente duro, friável quando úmido e ligeiramente plástico e ligeiramente pegajoso quando molhado. $\mathrm{O}$ horizonte B é do tipo B textural, apresentando-se subdividido em Bt e BC, exceto no NCL que tem somente o horizonte Bt. A espessura deste horizonte varia de 15 a $25 \mathrm{~cm}$, com a menor sendo verificada no NCL. A cor tem matiz de 2.5YR (NCv), com valores 3 e croma 4 a 6 e 5 YR valor de 3 a 4 e croma de 3 a 6 para os outros dois perfis. A textura apresenta-se variando desde franco 
arenosa até argila arenosa e a estrutura é bem desenvolvida do tipo blocos angulares e/ou subangulares com grau de fraca a forte e classe média a muito grande. A consistência é macio a muito duro quando seco, friável a muito firme quando úmido e ligeiramente plástico a plástico e ligeiramente pegajoso a pegajoso quando molhado. Foi também constatada na área destes solos a ocorrência de pedregosidade superficial, formada por calhaus e matacões de quartzo arredondados a sub arredondados, constituindo o chamado pavimento desértico, conforme citado em Brasil (1973). Os atributos morfológicas dos solos também estão de acordo com as descrições contidas em Brasil (1973).

A granulometria nos três perfis (tabelas 2 e 3), mosta uma nítida diminuição dos conteudos de areia grossa e média $(2000-200 \mu \mathrm{m})$ no horizonte Bt em relação aos horizontes $\mathrm{Cr}$ e R. Aproximadamente na mesma proporção, aumentam os teores de argila $(<2 \mu \mathrm{m})$ e silte fino $(20-2 \mu \mathrm{m})$, em contraposição aos horizontes $\mathrm{Cr}$ e $\mathrm{R}$, uma indicação de processos intensivos de decomposição e de formação de argila no solo. A quantidade de silte grosso $(53-20 \mu \mathrm{m})$ é diminuta em todos os perfis e se modifica muito pouco ao longo dos horizontes. Os teores de argila crescem do horizonte A para o B, exceto no perfil 5 que tem o seu horizonte superficial praticamente todo truncado. Nos outros dois perfis são evidenciados gradientes texturais de 4,1 no NCL e 1,9 no NC.

As tabelas $6,7,8$ e 9 demonstram o complexo sortivo e alguns atributos químicos, dos vários horizontes dos três perfis. Verifica-se através dos resultados a alta atividade da argila, bem como a saturação e soma por bases elevada, principalmente no horizonte B textural, aspectos esses 
concordantes com Brasil (1973), Oliveira et al. (1992) e Camargo et al. (1987). Os teores de cálcio e magnésio são os mais elevados no complexo sortivo, variando relativamente pouco do A para o B. O potássio apresentase em teores mais baixos que os dois primeiros cations e decresce com a profundidade, resultados semelhantes foram também encontrados por Sousa (1986). Os valores de ki e kr são maiores no perfil 5 do que nos outros dois, o que pode ser explicado pela maior proporção de argilo-minerais 2:1 (esmectita) nesse perfil, o que lhe confere caráter vértico, concordando também com a sua drenagem interna e posição na parte mais baixa do relevo, onde a acumulação de ions normalmente é maior. A reação dos solos é de uma baixa acidez (variação do $\mathrm{pH}$ em água de 5,8 a 6,9) com os valores de 6,0 a 6,3 sendo os mais frequentes. O carbono e a matéria orgânica são baixos em todos os perfis e decrescem com a profundidade, com o clima semi-árido e a vegetação de caatinga hiperxerófila, contribuindo para justificar esses teores. A condutividade elétrica e o sódio trocável são também baixos em toda topossequência, não existindo nenhum processo de salinização ou alcalinização.

\subsubsection{Solos de Guaramiranga}

Foram estudados dois perfis (6 e 7 - figura 6, pg. 52 ), estando um localizado na vertente úmida e outro na vertente mais seca da serra de Guaramiranga; que geomorfologicamente está associada ao domínio geológico dos planaltos residuais, que no Estado do Ceará ficam quase sempre circundados pelas depressões sertanejas, resultantes de processos de 
pediplanação. Tais perfis embora não estejam localizados em ambiente semiárido, são também derivados de gnaisses referidos ao Pré-Cambriano Indiviso. Foram incluidos na pesquisa para o estabelecimento de comparação e também pelo fato da microrregião de Guaramiranga está localizada muito próxima de Fortaleza (aproximadamente $120 \mathrm{Km}$ ), e ser uma área de agricultura mais intensiva, especialmente com fruticultura e horticultura, devido ao microambiente onde a mesma está localizada ser mais úmido e com temperatura mais amena, condicionados pela maior altitude.

No planalto residual da serra de Baturité predominam grandemente os Podzólicos Vermelho-Amarelos distróficos (PVd) e álicos (PVa), ocorrendo também Podzólicos Vermelho-Escuros (PEd ou PEa), mapeados a princípio como PVd, antes do estabelecimento e definição dessa última classe de solo, corroborando com o citado por Jacomine (1996).

O perfil $6(\mathrm{PEa})$, está localizado na vertente úmida e a uma maior altitude (900 m), enquanto que o perfil 7 (PVa), fica situado na vertente seca, logo após a transição entre as duas vertentes a uma altitude de cerca de 600 m. A profundidade do "solum" em ambos os perfis é de $130 \mathrm{~cm}$, com a ocorrência de erosão laminar severa em tais solos, resultando na remoção parcial do horizonte A nos dois casos. A diferenciação de cor entre os dois solos está associada com o teor de ferro (tabelas 6 e 8), bem como com a posição na paisagem e drenagem interna no perfil. O PEa com melhor drenagem e aeração tem o ferro provavelmente em maior proporção na forma oxidada, daí sua coloração vermelha com matiz 2.5 YR no B textural. Por sua vez o PVa com drenagem interna moderada e menor aeração, apresenta características de plintização no $\mathrm{Bt}$, com coloração variegada e certamente 
maior teor de ferro na forma reduzida. A estrutura nos dois perfis é bem desenvolvida em blocos subangulares, com grau e classe variando ao longo do perfil de moderada a forte e média a grande respectivamente. Apenas no horizonte $\mathrm{AB}$ verifica-se a ocorrência de estrutura granular de grau fraca e moderada. São solos friáveis quando úmidos e ligeiramente plásticos e ligeiramente pegajosos a plásticos e pegajosos quando molhados. Os dois solos apresentam cerosidade moderada e comum no horizonte $B$, que combinada com o truncamento parcial dos perfis, a despeito do baixo gradiente textural $\mathrm{B} / \mathrm{A}$, fornecem uma base teórica para qualificá-los como Bt.

As tabelas 2, 4, 6 e 8 mostram alguns dos principais atributos físicos e químicos dos solos estudados. Ambos os perfis são de textura média e mostram pouco aumento de argila com a profundidade. Os valores de densidade de partículas, densidade do solo, volume total de poros e retenção de água são muito semelhantes nos dois casos, o mesmo ocorrendo com a relação silte/argila, que apresenta uma diferença acentuada apenas no horizonte $\mathrm{C}$ do perfil 7, quando comparado ao mesmo horizonte no perfil 6. $\mathrm{O}$ complexo sortivo, os valores de $\mathrm{ki}$ e $\mathrm{kr}$ e os principais atributos químicos também pouco diferem. As exceções ficam por conta do carbono, caráter álico e ferro. Os dois primeiros são mais acentuados no $\mathrm{PEa}$, o que pode ser explicado pelas condições mais úmidas e vegetação mais exuberante nessa parte da vertente. Os teores de Fed e $\mathrm{Fe}_{2} \mathrm{O}_{3}$ são mais elevados no $\mathrm{PVa}$, que estando situado na parte mais baixa da topossequência e tendo drenagem interna mais restringida, propicia um maior acúmulo de ferro na forma reduzida, que é sabidamente uma forma mais móvel e de maior acumulação 
no solo. O processo de plintização verificado nesse perfil, também justifica o mencionado acima. A argila é de atividade baixa e a soma a saturação por bases e o pH são também baixos nos dois perfis. Os valores de ki e kr são muito semelhantes nos dois solos, sendo um pouco mais elevados no horizonte $\mathrm{C}$ do perfil 7, o que de certa forma pode ser um indício de uma menor intensidade de intemperização na vertente mais seca.

\subsubsection{Solos de Tauá}

Está constituida por dois perfis (8 e 9), localizados no município de Tauá - Ce. A descrição morfológica, as análises de rotina e a mineralogia do perfil 9 (Aluvial eutrófico sódico - AL), encontram-se no anexo $B$, uma vez que devido a pouca representatividade espacial dos solos aluviais no Estado do Ceará, a mencionada classe de solo não foi incluida como representativa da pesquisa. No entanto os atributos físicos, químicos e mineralógicos desse perfil são importantes na discussão da topossequência como um todo. $\mathrm{O}$ perfil 8, um Planossolo Solódico (PL), com ocorrência frequente na região, ocupa as posições de topo e encosta do relevo e o solo aluvial a parte mais baixa, estando associado com depósitos aluviais holocênicos estratificados (figura 7, pg. 53).

A profundidade dos solos guarda relação estreita com a posição dos dois perfis na paisagem. Assim sendo, o PL é mais raso enquanto que o AL é mais profundo por estar situado na zona de maior acumulação. Em toda a extensão da topossequência a condição de drenagem interna é imperfeita 0 que se manifesta em cores acinzentadas e/ou presença de mosqueado. A 
estrutura é bem desenvolvida nos dois perfis em blocos angulares, subangulares ou prismática, de grau forte e tamanho média a grande. A consistência no perfil 8, é ligeiramente duro quando seco no horizonte A e extemamente duro no $2 \mathrm{Btn}$; quando úmido varia de friável a extremamente firme e quando molhado de não plástico e ligeiramente pegajoso a muito plástico e muito pegajoso. Esses atributos distoantes de estrututra e consistência dos horizontes A e 2Btn, associados com um incremento de argila do A para o 2Btn de cerca de $170 \mathrm{~g} \mathrm{~kg}^{-1}$ (gradiente textural $=2,4$ ), como pode ser visto na tabela 3, caracterizam uma textura média/ contrastante com mudança textural abrupta, comum nos Planossolos, concordando com Oliveira et al. (1992) e Camargo et al. (1987).

O solo Aluvial tem consistência muito duro, muito firme, plástico e pegajoso ao longo de todo o perfil e distribuição bastante irregular de granulometria e relação silte/argila, o que é característico desses solos estratificados, formados de materiais transportados e depositados de natureza geológica diferente.

O complexo sortivo e alguns atributos químicos dos solos podem ser observados nas tabelas 7 e 9 e anexo B. O aspecto mais notório que diferencia os dois perfis na topossequência é o aumento da $\% \mathrm{de}^{+}$do topo para a faixa aluvional. Enquanto o perfil 8 ( PL ), tem $9 \%$ de sódio trocável (caráter solódico) no horizonte 2Btn, os horizontes $2 \mathrm{C} 1,2 \mathrm{C} 2$ e $3 \mathrm{C} 3$ do solo aluvial têm 49,8, 38,9 e 33,6 de $\mathrm{Na}^{+}$respectivamente (caráter sódico). Isso traduz de certa forma um possível transporte de tal elemento por fluxo lateral e/ou basal de água, das partes mais altas para a mais baixa da vertente, devido a relativa mobilidade do ion sódio. Os dados de $\mathrm{CTC}, \mathrm{V} \%, \mathrm{pH}$ e $\mathrm{CE}$ 
não são tão contrastantes quanto o sódio trocável, embora todos esses atributos apresentem valores considerados altos. Os teores de carbono, são baixos, concordando com as condições vigentes de semi-aridez, embora haja uma quase duplicação da quantidade de C quando se compara o horizonte superficial nos dois solos.

\subsubsection{Perfis da BR - 222}

Referem-se a dois perfis ao longo da BR - 222, na direção Fortaleza Sobral, que embora não possam ser considerados como integrantes de uma topossequência, em razão da relativa grande distância entre os dois (figura 8, pg.54) são classes de solos de importância espacial no Estado, ambos alfissolos, com regime hídrico ústico. O perfil 10 é um Podzólico VermelhoAmarelo eutrófico (PVe), derivado de granito enquanto que o perfil 11 é um Solonetz Solodizado eutrófico (SS), na zona fisiográfica do litoral, porém já na transição para o semi-árido. Este é originado de gnaisse relacionado ao Pré-Cambriano Indiviso, o mesmo ocorrendo com o granito supra mencionado.

A profundidade do "solum" varia de $113 \mathrm{~cm}$ no PVe a $62 \mathrm{~cm}$ no SS. $\mathrm{O}$ primeiro é bem drenado enquanto o segundo apresenta restrições de drenagem interna, podendo ser considerada de moderada a imperfeita. Isso é refletido, evidentemente, nas cores dos dois solos, como pode ser observado nas descrições morfológicas (anexo A). A estrutura é predominantemente moderada grande em blocos subangulares no PVe e forte grande colunar no horizonte $2 \mathrm{Btn}$ do SS. A presença de cerosidade foi detectada no campo nos 
horizontes Btl e Bt2 do perfil 10, com tal feição morfológica não sendo verificada no perfil 11.

Os principais atributos físicos e químicos dos dois perfis estão apresentados nas tabelas 2, 3, 4, 5, 6, 7, 8 e 9. Enquanto o SS apresenta-se na categoria de um solo com acentuado aumento de argila em profundidade (gradiente textural $\mathrm{B} / \mathrm{A}=3,8$ ), o $\mathrm{PVe}$ tem um gradiente de 1,7 . A relação silte/argila mostra valores bem mais altos em todos os horizontes do perfil 11, quando comparado com o perfil 10, traduzindo nesse último, de certo modo, uma maior maturidade. Os valores de densidade do solo e volume total de poros, também diferem nos solos estudados, mormente no horizonte Btn do SS, que tem densidade mais elevada e VTP mais baixo.

Os atributos químicos apresentam maiores diferenças em termos de $\mathrm{pH}, \mathrm{CTC}$ e sódio trocável. No perfil $10 \mathrm{o} \mathrm{pH}$ situa-se na faixa de fraca acidez, no perfil 11, há uma variação de moderada acidez nos horizontes superficiais, até fracamente alcalina $(\mathrm{pH}=7,9$ no horizonte $2 \mathrm{Btn})$. Os horizontes mais inferiores do SS devido aos altos teores $\mathrm{de}^{+}{ }^{+}(31,6 \%$ no 2Btn) mostram um processo de alcalinização, enquanto no PVe a $\%$ de $\mathrm{Na}^{+}$ no $\mathrm{Bt}$ é de no máximo $2 \%$. A CTC no perfil 10 é mais baixa no $\mathrm{Bt}$ do que no perfil 11 , não obstante a sua maior quantidade de argila. Todavia os dois solos são considerados como tendo argila de atividade baixa. 


\subsection{Mineralogia e transformações mineralógicas}

\subsubsection{Solos de Quixadá}

A - Frações areia e silte

A fração areia do perfil 1 ( PVe ), apresenta dominância de quartzo e biotita seguidos de feldspato ( plagioclásios ). As quantidades de biotita são superiores as de quartzo apenas no horizonte mais inferior (2BC), diminuindo consideravelmente ou mesmo desaparecendo em direção à superficie. O quartzo aumenta nesse mesmo sentido voltando a diminuir no horizonte $\mathrm{AB}$. Evidências de campo e interpretação das análises mineralógicas (tabela 10), mostram haver influência de material pedimentar retrabalhado até o horizonte $\mathrm{Bt} 1$ (vide anexo $\mathrm{A}$ ). $\mathrm{Na}$ fração silte a composição básica predominante também é biotita e quartzo, seguindo a mesma tendência observada na areia. No silte fino já existe a ocorrência de caulinita, com maior quantidade nos horizontes $2 \mathrm{BC}$ e $2 \mathrm{Bt} 2$ e uma distribuição mais ou menos uniforme nos demais. Minerais opacos e incrustações de óxidos de ferro também ocorrem em quantidades diminutas na fração areia $(>200 \mu \mathrm{m})$. Os resultados aqui encontrados (PVe), estão de acordo com os descritos em Brasil (1973), discordando apenas no teor de biotita. Também Ribeiro et al. (1991) e Souza et al. (1993), encontraram quartzo como o mineral predominante em perfis de PVe no semi-árido nordestino brasileiro. 
Tabela 10. Mineralogia do perfil 1 ( $\mathrm{PVe}$ ), em $\%$ de peso da terra fina $<2 \mathrm{~mm}\left(\mathrm{~g} \mathrm{~kg}^{-1}\right.$ ).

\begin{tabular}{|c|c|c|c|c|c|c|c|c|}
\hline \multirow[b]{2}{*}{ Horiz. } & \multirow[b]{2}{*}{ Prof.(cm) } & \multicolumn{7}{|c|}{ Tamanho da fração $(\mu \mathrm{m})$} \\
\hline & & Mineral & $>200$ & $200-53$ & $53-20$ & $20-2$ & $<2$ & $\Sigma$ \\
\hline \multirow{9}{*}{$\mathrm{AB}$} & \multirow{9}{*}{$12-43$} & Quartzo & 436 & 231 & 31 & 15 & 12 & 725 \\
\hline & & Plagioclásio & 7 & 39 & 9 & - & - & 55 \\
\hline & & Biotita $^{2}$ & - & 7 & 6 & 2 & - & 15 \\
\hline & & Homblenda & - & 5 & - & - & - & 5 \\
\hline & & Min. opaco & - & - & - & - & - & - \\
\hline & & Incrustação $^{3}$ & - & 7 & - & - & - & 7 \\
\hline & & Caulinita & - & - & - & 17 & 128 & 145 \\
\hline & & Vermiculita & - & - & - & - & 50 & 50 \\
\hline & & $\sum$ & 443 & 289 & 46 & 34 & 190 & 1002 \\
\hline \multirow{9}{*}{ BA } & \multirow{9}{*}{$43-74$} & Quartzo & 505 & 163 & 24 & 14 & 16 & 722 \\
\hline & & Plagioclásio & 15 & 30 & 10 & 6 & - & 61 \\
\hline & & Biotita & - & - & 17 & - & - & 17 \\
\hline & & Homblenda & - & - & - & - & - & - \\
\hline & & Min. opaco & - & 2 & 2 & - & - & 4 \\
\hline & & Incrustação & 11 & 3 & - & - & - & 14 \\
\hline & & Caulinita & - & - & - & 9 & 112 & 121 \\
\hline & & Vermiculita & - & - & - & - & 62 & 62 \\
\hline & & $\Sigma$ & 531 & 198 & 53 & 29 & 190 & 1001 \\
\hline \multirow{9}{*}{ Btl } & \multirow{9}{*}{$74-119$} & Quartzo & 399 & 194 & 21 & 11 & 21 & 646 \\
\hline & & Plagieclásio & 24 & 23 & 13 & 7 & - & 67 \\
\hline & & Biotita & 13 & 10 & 17 & - & - & 40 \\
\hline & & Homblenda & 3 & - & - & - & - & 3 \\
\hline & & Min. opaco & 3 & - & 1 & - & - & 4 \\
\hline & & Incrustação & - & - & 1 & - & - & 1 \\
\hline & & Caulinita & - & - & - & 12 & 144 & 156 \\
\hline & & Vermiculita & - & - & - & - & 65 & 65 \\
\hline & & $\Sigma$ & 442 & 227 & 53 & 30 & 230 & $982^{4}$ \\
\hline \multirow{9}{*}{$2 \mathrm{Bt} 2$} & \multirow{9}{*}{$119-185$} & Quartzo & 180 & 119 & 14 & 3 & 15 & 337 \\
\hline & & Plagioclásio & 13 & 18 & 5 & 6 & - & 42 \\
\hline & & Biotita & 71 & 73 & 62 & - & - & 206 \\
\hline & & Hormblenda & - & - & - & - & - & - \\
\hline & & Min. opaco & - & - & - & - & - & - \\
\hline & & Incrustação & - & - & - & - & - & - \\
\hline & & Caulinita & - & - & - & 42 & 233 & 275 \\
\hline & & Vermiculita & - & - & - & - & 102 & 102 \\
\hline & & $\sum$ & 264 & 210 & 81 & 57 & 350 & 962 \\
\hline \multirow{9}{*}{$2 \mathrm{BC}$} & \multirow{9}{*}{$185-205 \neq$} & Quartzo & 170 & 88 & 3 & 8 & 14 & 283 \\
\hline & & Plagioclásio & 12 & 12 & $=$ & 5 & $=$ & 29 \\
\hline & & Biotita & 210 & 100 & 76 & 7 & - & 393 \\
\hline & & Hornblenda & - & - & - & - & - & - \\
\hline & & Min opaco & 5 & - & - & - & - & 5 \\
\hline & & Incrustação & 5 & - & $=$ & $=$ & $=$ & 5 \\
\hline & & Caulinita & - & - & - & 41 & 84 & 125 \\
\hline & & Vermiculita & - & - & - & - & 152 & 152 \\
\hline & & $\Sigma$ & 402 & 200 & 79 & 61 & 250 & 992 \\
\hline
\end{tabular}

1) Predominantemente albita;

2) Preponderantemente flogopita - biơtita nas fraçōes areia e silte

3) Óxido de ferro;

4) A diferença para 1000 está associada a minerais pesados e indeterminados. 
Tabela 11. Mineralogia do perfil 2 ( PL ), em $\%$ de peso da terra fina $<2 \mathrm{~mm}\left(\mathrm{~g} \mathrm{~kg}^{-1}\right)$.

Tamanho da fração $(\mu \mathrm{m})$

Horiz. Prof.(cm) Tipo de Mineral $\quad>200 \quad 200-53 \quad 53-20 \quad \Sigma$

\begin{tabular}{|c|c|c|c|c|c|c|}
\hline \multirow{8}{*}{ Ap } & \multirow{8}{*}{$0-15$} & Quarzo & 480 & 254 & 40 & 774 \\
\hline & & Plagioclásio ${ }^{1}$ & 28 & 34 & 25 & 87 \\
\hline & & Biotita & - & 13 & 17 & 30 \\
\hline & & Hornblenda & 28 & 5 & - & 33 \\
\hline & & Incrustação & 2 & 2 & 1 & 5 \\
\hline & & Min. Opaco & 2 & 2 & 1 & 5 \\
\hline & & & & & & 7 \\
\hline & & $\Sigma$ & 540 & 310 & 84 & 934 \\
\hline \multirow{7}{*}{ E } & \multirow{7}{*}{$15-45$} & Quartzo & 440 & 181 & 51 & 672 \\
\hline & & Plagioclásio & 63 & 30 & 24 & 117 \\
\hline & & Biotita & - & 54 & 5 & 59 \\
\hline & & Hornblenda & 27 & 6 & 1 & 34 \\
\hline & & Min. opaco & - & - & $=$ & - \\
\hline & & Incrustação & - & 9 & 2 & 11 \\
\hline & & $\Sigma$ & 530 & 280 & 83 & 893 \\
\hline \multirow{7}{*}{$2 \mathrm{Btn}$} & \multirow{7}{*}{$45-63$} & Quartzo & 285 & 117 & 30 & 432 \\
\hline & & Plagioclásio & 36 & 7 & 19 & 62 \\
\hline & & Biotita & 3 & 19 & 12 & 34 \\
\hline & & Hornblenda & 36 & 17 & - & 53 \\
\hline & & Min. opaco & - & - & - & - \\
\hline & & Incrustação & & 2 & - & 2 \\
\hline & & $\Sigma$ & 360 & 162 & 61 & 583 \\
\hline \multirow{7}{*}{$2 \mathrm{BCn}$} & \multirow{7}{*}{$63-79$} & Quartzo & 9 & 14 & 1 & 24 \\
\hline & & Plagioclásio & - & 1 & - & 1 \\
\hline & & Biotita & 613 & 65 & 19 & 697 \\
\hline & & Hornblenda & 88 & 29 & 2 & 119 \\
\hline & & Min. opaco & - & - & $=$ & - \\
\hline & & Incrustação & - & 3 & - & 3 \\
\hline & & $\Sigma$ & 710 & 112 & 22 & 844 \\
\hline \multirow{7}{*}{$2 \mathrm{Cr} 1$} & \multirow{7}{*}{$79-118$} & Quartzo & 7 & 2 & - & 9 \\
\hline & & Plagioclásio & - & - & - & - \\
\hline & & Biotita & 641 & 83 & 20 & 744 \\
\hline & & Hornblenda & 106 & 7 & 3 & 116 \\
\hline & & Incrustação & - & - & - & - \\
\hline & & Min. opaco & - & - & - & - \\
\hline & & $\Sigma$ & 754 & 92 & 23 & 869 \\
\hline \multirow{7}{*}{$2 \mathrm{Cr} 2$} & \multirow{7}{*}{$118-170+$} & Quartzo & 19 & - & - & 19 \\
\hline & & Plagioclásio & 7 & - & - & 7 \\
\hline & & Biotita & 473 & 124 & 23 & 620 \\
\hline & & Hornblenda & 280 & 15 & 2 & 297 \\
\hline & & Min. opaco & - & $=$ & - & $=$ \\
\hline & & Incrustação & - & 2 & - & 2 \\
\hline & & $\Sigma$ & 779 & 141 & 25 & 945 \\
\hline
\end{tabular}

1) Predominantemente albita 
Tabela 12. Mineralogia do perfil 2 (PL), em \% de peso da terra fina $<2 \mathrm{~mm}\left(\mathrm{~g} \mathrm{~kg}^{-1}\right)$.

\begin{tabular}{|c|c|c|c|c|c|}
\hline \multirow[b]{2}{*}{ Horiz. } & \multirow[b]{2}{*}{ Prof. (cm) } & \multirow[b]{2}{*}{ Tipo de mineral } & \multicolumn{3}{|c|}{ Tamanho da fração $(\mu \mathrm{m})$} \\
\hline & & & $20-2$ & $<2$ & $\Sigma$ \\
\hline \multirow{6}{*}{ Ap } & \multirow{6}{*}{$0-15$} & Quartzo & 7 & 1 & 8 \\
\hline & & Ilita & 1 & - & 1 \\
\hline & & Caulinita & 12 & 13 & 25 \\
\hline & & Vermiculita & - & 2 & 2 \\
\hline & & Min. Int. $2,4 \mathrm{~nm}^{1}$ & - & 6 & 6 \\
\hline & & $\Sigma$ & 20 & 22 & 42 \\
\hline \multirow{5}{*}{ E } & \multirow{5}{*}{$15-45$} & Quartzo & 13 & 9 & 22 \\
\hline & & Ilita & 3 & - & 3 \\
\hline & & Caulinita & 8 & 70 & 78 \\
\hline & & Min. Int. $2,4 \mathrm{~nm}$ & 8 & 9 & 17 \\
\hline & & $\Sigma$ & 32 & 88 & 120 \\
\hline \multirow{4}{*}{$2 \mathrm{Btn}$} & \multirow{4}{*}{$45-63$} & Quartzo & 17 & 36 & 53 \\
\hline & & Caulinita & 14 & 180 & 194 \\
\hline & & Esmectita & 17 & 144 & 161 \\
\hline & & $\Sigma$ & 48 & 360 & 408 \\
\hline \multirow{6}{*}{$2 \mathrm{BCn}$} & \multirow{6}{*}{$63-79$} & Quartzo & 2 & - & 2 \\
\hline & & Hornblenda & 8 & - & 8 \\
\hline & & Ilita & 2 & - & 2 \\
\hline & & Caulinita & 8 & 66 & 74 \\
\hline & & Esmectita & 10 & 30 & 40 \\
\hline & & Min. Int. $2,4 \mathrm{~nm}$ & 10 & 24 & 34 \\
\hline \multirow{8}{*}{$2 \mathrm{Cr} 1$} & \multirow{8}{*}{$79-118$} & $\Sigma$ & 40 & 120 & 160 \\
\hline & & Quartzo & 3 & 9 & 12 \\
\hline & & Hornblenda & 8 & - & 8 \\
\hline & & Ilita & 3 & - & 3 \\
\hline & & Vermiculita & 10 & - & 10 \\
\hline & & Esmectita & - & 29 & 29 \\
\hline & & Caulinita & 3 & 49 & 52 \\
\hline & & Min. Int. $2.4 \mathrm{~nm}$ & 5 & 9 & 14 \\
\hline \multirow{8}{*}{$2 \mathrm{Cr} 2$} & \multirow{8}{*}{$118-170+$} & $\Sigma$ & 32 & 96 & 128 \\
\hline & & Quartzo & 4 & - & 4 \\
\hline & & Ilita & 3 & - & 3 \\
\hline & & Hornblenda & 4 & - & 4 \\
\hline & & Caulinita & 1 & 13 & 14 \\
\hline & & Esmectita & - & 18 & 18 \\
\hline & & Min. Int. $2,4 \mathrm{~nm}$ & 4 & 4 & 8 \\
\hline & & $\Sigma$ & 16 & 35 & 51 \\
\hline
\end{tabular}

1) Interestratificação regular de vermiculita + mica. 

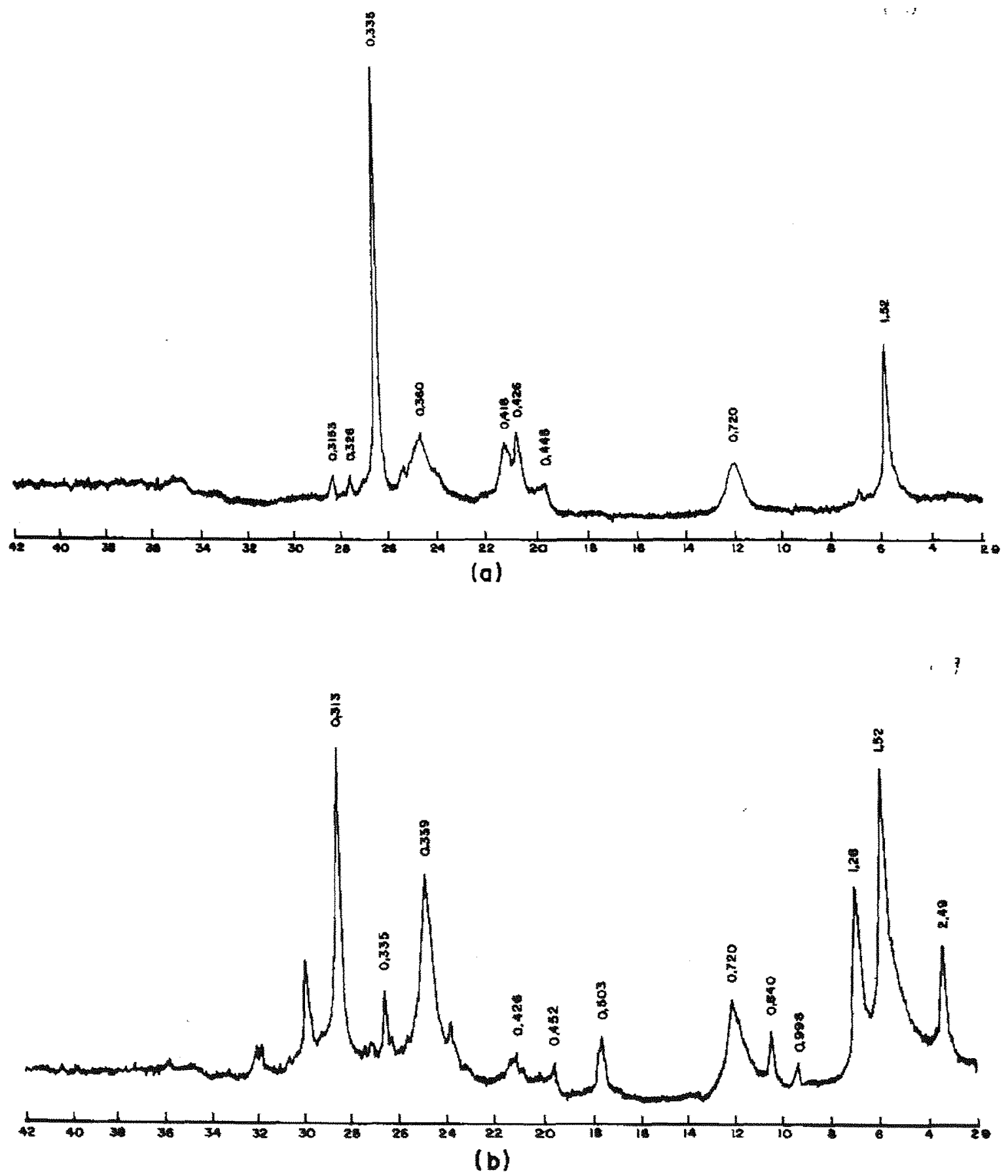

Figura 9 - Difratogramas da fração silte fino do perfil 2 (PL). (a) horizonte Ap; (b) hori zonte $2 \mathrm{Btn}$ e (c) horizonte $2 \mathrm{Cr} 2$ (tratamentos com $\mathrm{K}^{+}$a $25^{\circ} \mathrm{C}$ ). 


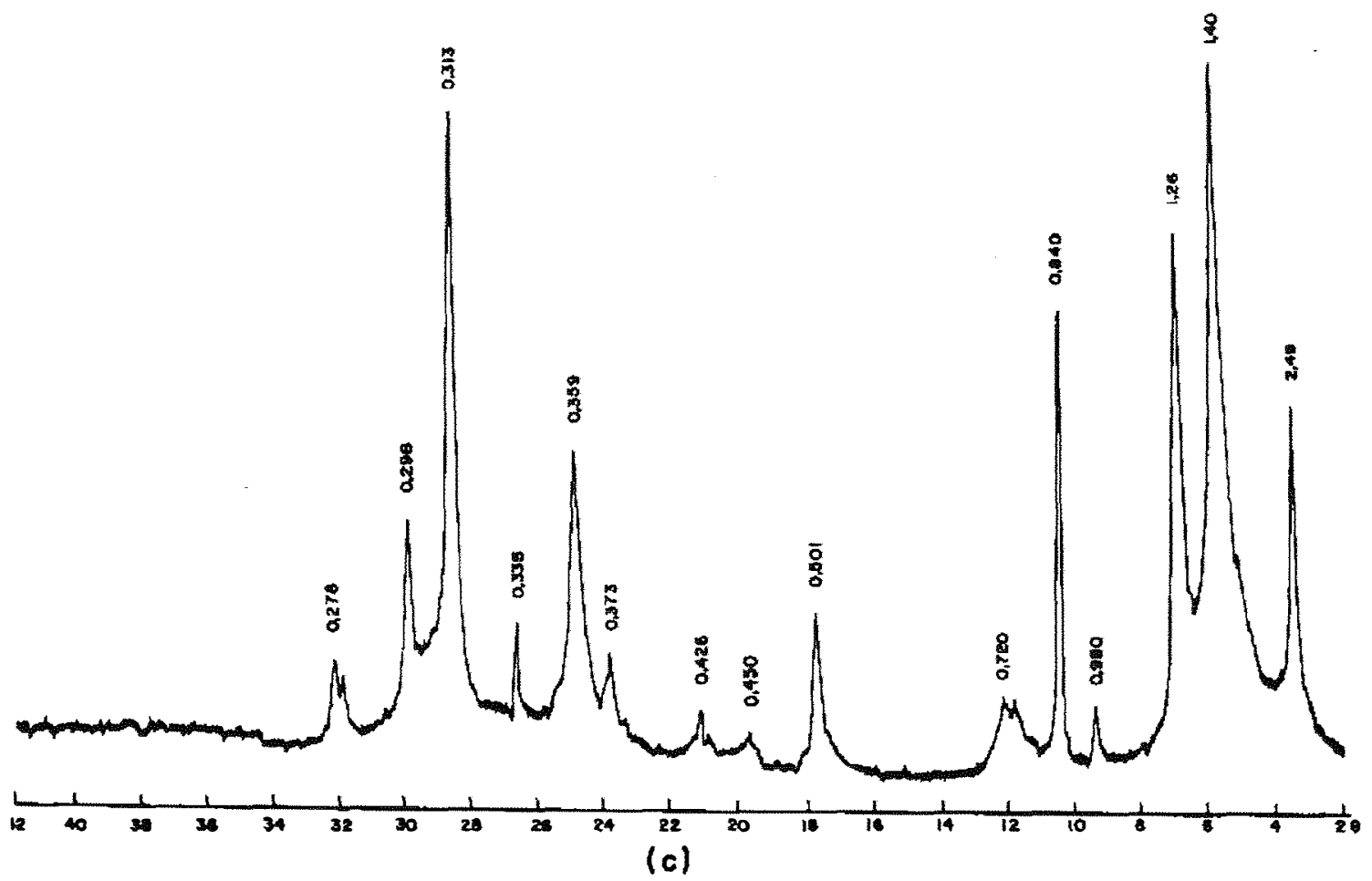

Figura 9 - Difratogramas da fração silte fino do perfil 2 (PL). (a) horizonte $\mathrm{Ap}$; (b) horizonte $2 \mathrm{Btn}$ e (c) horizonte $2 \mathrm{Cr} 2$ (tratamentos com $\mathrm{K}^{+}$ a $\left.25^{\circ} \mathrm{C}\right)$.

Isso reforça a afirmativa de Allen \& Fanning (1983), de que a mineralogia das frações mais grosseiras em alfissolos e aridissolos, normalmente está associada com a natureza mineralógica dos diferentes materiais de origem desses solos. O perfil 2 (PL), tem nas frações mais grosseiras (tabela 11), dominância de biotita e hornblenda seguido de quartzo e plagioclásio. Os dois primeiros minerais considerados mais intemperizáveis, diminuem as suas quantidades dos horizontes $2 \mathrm{Cr} 1$ e $2 \mathrm{Cr} 2$ para o $2 \mathrm{Btn}$, enquanto que o quartzo aumenta em direção à superfície, com maiores teores nos horizontes Ap e E, tipicamente de natureza pedimentar. 


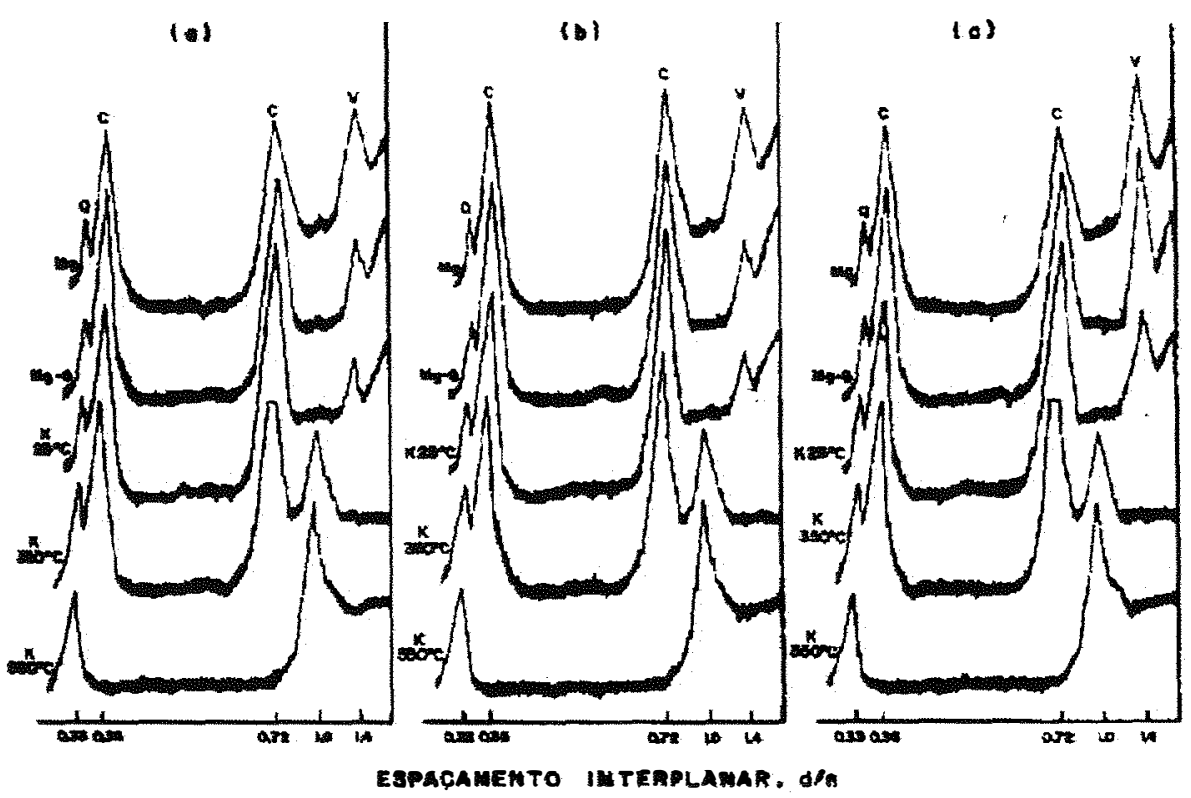

Figura 10 - Difratogramas da fração argila do perfil 1 (PVe). (a) horizonte AB; (b) hori zonte $2 \mathrm{Bt} 2 \mathrm{e}(\mathrm{c})$ horizonte $2 \mathrm{BC}$ (amostra orientada).

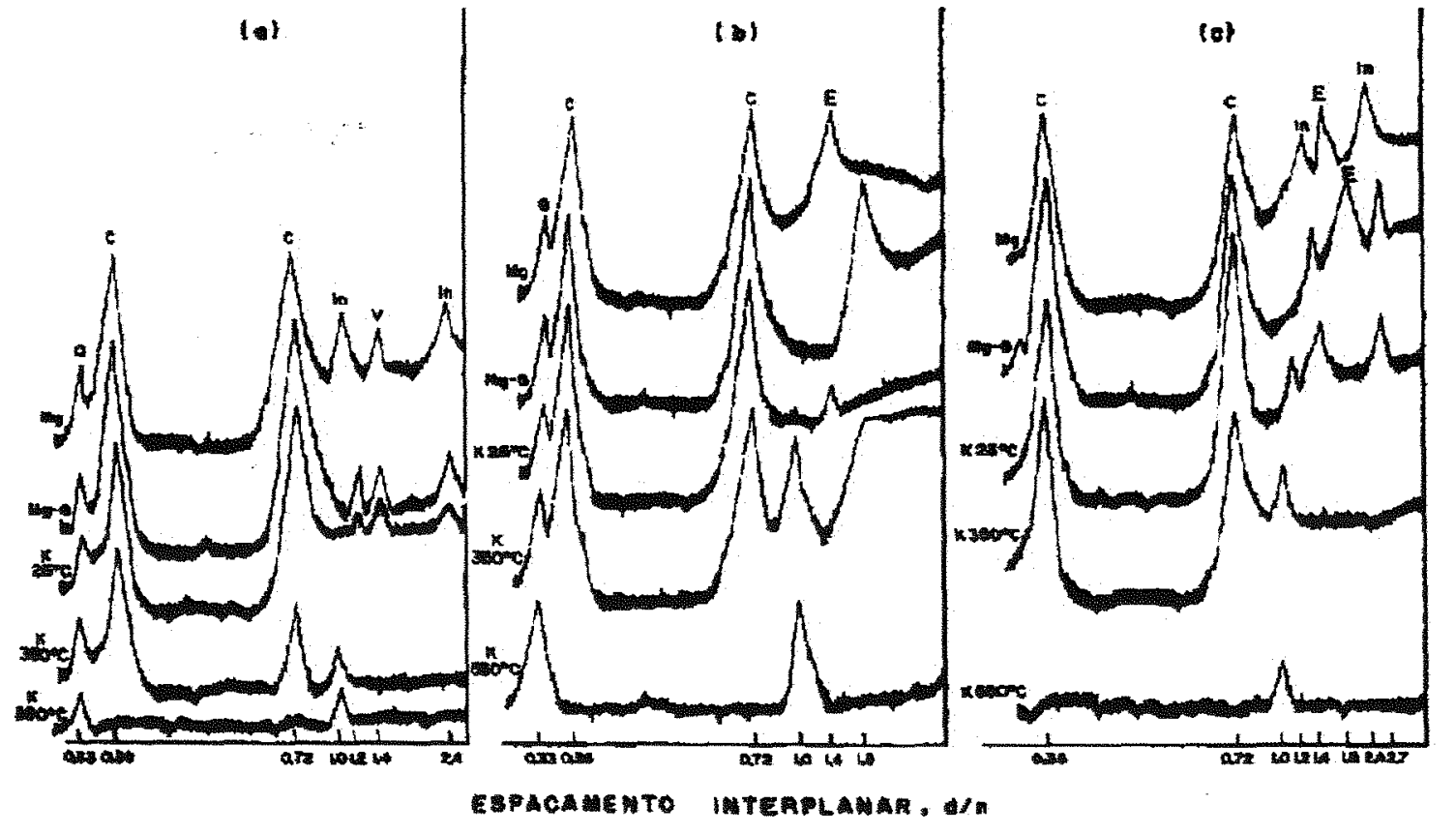

Figura 11 - Difratogramas da fração argila do perfil 2 (PL). (a) horizonte Ap; (b) horizon te $2 \mathrm{Btn}$ e (c) horizonte $2 \mathrm{Cr} 2$ (amostra orientada). 
No silte fino já são evidentes minerais secundários como ilita, caulinita, esmectita, vermiculita e um mineral interestratificado regular de vermiculita + mica, com espaçamento de 2,4 nm (figura 9), presente nos horizontes inferiores e ausente no 2Bth. Esses resultados concordam em parte com os contidos em Brasil (1973) e os citados por Tomar et al. (1985), Almeida (1989), Batista (1988) e Luz et al. (1992).

\section{B - Fração argila}

O conjunto de minerais encontrados na fração argila nos dois perfis (tabelas 10 e 12), diferem qualitativamente em função da posição no relevo. No PVe que ocupa posições de topo e encosta e tem melhor drenagem, há uma constância em todo o perfil de caulinita, vermiculita e quartzo. No PL com drenagem imperfeita, ocorrem além dos minerais já citados, também esmectita e um mineral interestratificado regular de vermiculita + mica, reconhecido pelos picos a 2,4 e 1,2 $\mathrm{nm}$ (figuras 10 e 11). No perfil 1 os teores de vermiculita aumentam da superficie para os horizontes inferiores sendo resultantes de transformações de biotitas mais abundantes nessa posição. A caulinita por sua vez, aumenta do horizonte $2 \mathrm{BC}$ para o $2 \mathrm{Bt} 2$, horizonte mais rico em argila, e volta a diminuir em direção a superfície. No perfil 2 as quantidades de caulinita aumentam no sentido ascendente ou seja do $2 \mathrm{Cr} 2$ para o $2 \mathrm{Btn}$. Os horizontes $\mathrm{Ap}$ e $\mathrm{E}$ não guardam relação com a rocha subjacente, daí as suas discrepâncias mineralógicas com os demais horizontes do perfil. A esmectita e o mineral interestratificado também crescem seus valores do $2 \mathrm{Cr} 2$ para o $2 \mathrm{Btn}$, onde a quantidade de esmectita é máxima. Nesse último horizonte, porém, não foi mais detectado o mineral interestratificado que possivelmente se alterou para esmectita e/ou caulinita. 
Os resultados aqui citados, concordam totalmente ou em parte com Allen \& Fanning (1983); Schmehl \& Jackson (1956); Mc Neal \& Sansoterra (1964); Klages \& Southard (1968); Tomar et al. (1985); Almeida (1989); Batista (1988); Ribeiro et al. (1991); Luz et al. (1992); Souza et al. (1993); Costa (1994); Góis (1995).

Os dois solos PVe e PL, localizam-se na mesma zona fisiográfica estando sujeitos às mesmas condições de clima e vegetação. As diferenças ficam por conta do mineral hornblenda que ocorre em quantidade significativa no material de origem do perfil 2 e também no que se refere à drenagem interna deficiente desse último solo. O Planossolo Solódico em função de sua drenagem e posição no relevo, é afetado por uma menor lixiviação, além do enriquecimento de cations e anions a que está submetido, originados das partes mais altas da topossequência. Tudo isso, tem implicações na gênese dos minerais de argila, nos valores de CTC, na saturação por bases, \% de sódio trocável e relações sílica/alumina e sílica/sesquióxidos, com valores mais elevados no PL quando confrontado com o PVe (tabelas 8, 9, 10 e 12).

\subsubsection{Solos de Canindé}

A - Frações areia e silte

As tabelas 13, 14, e 15 mostram os dados referentes à mineralogia das diversas frações dos perfis 3, 4 e 5. Na fração areia grossa $(>200 \mu \mathrm{m})$, em todos os perfis há uma predominância do mineral quartzo, exceto no $\mathrm{NCv}$ onde já há nessa fração uma predominância de hornblenda, em razão da natureza da rocha subjacente (Hornblenda-Gnaisse). Na fração areia fina 
(200 - $53 \mu \mathrm{m}$ ), o quartzo é predominante apenas nos horizontes A e Bt do $\mathrm{NCL}$ (perfil 4), nos outros dois NC (perfil 3) e NCv (perfil 5), predominam respectivamente biotita e hornblenda. Tal fato está concordante com a riqueza desses minerais no material originário desses solos. Esses teores mais elevados de biotita e hornblenda na fração areia em relação ao quartzo, discordam dos encontrados em Brasil (1973); concordam em parte com os citados por Antonello (1989). As quantidades de feldspatos (plagioclásios), constituidos preponderantemente de albita e andesita, são relativamente pequenas nos três perfis (variação de 3 a $25 \mathrm{~g} \mathrm{~kg}^{-1}$ ) na areia grossa e (4 a 65 $\left.\mathrm{g} \mathrm{kg}^{-1}\right)$ na areia fina.

$\mathrm{Na}$ fração silte dos três solos encontrou-se ainda uma maior quantidade dos minerais primários (biotita, quartzo, hornblenda e plagioclásios) em relação aos minerais secundários caulinita e esmectita, principalmente no silte grosso. No silte fino, as quantidades de caulinita já superam àquelas dos minerais primários. Também nessa fração as quantidades de biotita e/ou hornblenda tendem a ser menores do que as de plagioclásios, mostrando desse modo uma maior estabilidade dos minerais félsicos em relação aos máficos, mormente nos perfis 3 e 4 (Goldich, 1938; Brewer, 1976; Allen \& Fanning, 1983).

As figuras 12, 13 e 14 apresentam os difratogramas do silte fino de alguns horizontes dos três pedons dos Bruno Não-Cálcicos estudados. 
Tabela 13. Mineralogia do perfil 3 ( NC ), em \% de peso da terra fina $<2 \mathrm{~mm}\left(\mathrm{~g} \mathrm{~kg}^{-1}\right.$ ).

Tamanho da fração $(\mu \mathrm{m})$

Horiz. Prof.(cm) Tipo de Mineral $>200 \quad 200-53 \quad 53-20 \quad 20-2 \quad<2 \quad \Sigma$

\begin{tabular}{|c|c|c|c|c|c|c|c|c|}
\hline \multirow{5}{*}{ A } & \multirow{5}{*}{$0-15$} & Quartzo & 350 & 180 & 24 & 10 & - & 564 \\
\hline & & Biotita $^{\mathrm{l}}$ & 19 & 80 & 32 & 25 & 65 & 231 \\
\hline & & Plagioclásio $^{2}$ & 3 & 6 & 27 & 40 & - & 76 \\
\hline & & Caulinita & - & $=$ & 2 & 23 & 31 & 56 \\
\hline & & $\Sigma$ & 372 & 276 & 85 & 98 & 96 & $927^{3}$ \\
\hline \multirow{6}{*}{$\mathrm{Bt}$} & \multirow{6}{*}{$15-34$} & Quarzo & 280 & 81 & 18 & 20 & - & 399 \\
\hline & & Biotita & 18 & 200 & 30 & 26 & 40 & 314 \\
\hline & & Plagioclásio & - & 6 & 7 & 38 & - & 51 \\
\hline & & Caulinita & - & - & 4 & 46 & 120 & 170 \\
\hline & & Esmectita & - & - & - & - & 30 & 30 \\
\hline & & $\Sigma$ & 298 & 287 & 59 & 130 & 190 & 964 \\
\hline \multirow{6}{*}{$\mathrm{BC}$} & \multirow{6}{*}{$34-50$} & Quartzo & 290 & 71 & 26 & 17 & - & 404 \\
\hline & & Biotita & 42 & 210 & 45 & 22 & 20 & 339 \\
\hline & & Plagioclásio & 3 & 6 & 8 & 34 & - & 51 \\
\hline & & Caulinita & - & - & 3 & 47 & 110 & 160 \\
\hline & & Esmectita & - & - & - & - & 20 & 20 \\
\hline & & $\Sigma$ & 335 & 287 & 82 & 120 & 150 & 974 \\
\hline \multirow{6}{*}{$\mathrm{Cr}$} & \multirow{6}{*}{$50-70$} & Quartzo & 300 & 62 & 10 & 4 & - & 376 \\
\hline & & Biotita & 260 & 210 & 38 & 15 & 9 & 532 \\
\hline & & Plagioclásio & 3 & 6 & 7 & 9 & - & 25 \\
\hline & & Caulinita & - & - & 3 & 15 & 15 & 33 \\
\hline & & Esmectita & - & $=$ & - & - & 3 & 3 \\
\hline & & $\Sigma$ & 563 & 278 & 58 & 43 & 27 & 969 \\
\hline \multirow{6}{*}{$\mathrm{R}$} & \multirow{6}{*}{$70+$} & Quarzo & 340 & 63 & 1 & 1 & - & 405 \\
\hline & & Biotita & 330 & 190 & 4 & 15 & 7 & 546 \\
\hline & & Plagioclásio & 5 & 4 & 1 & 2 & - & 12 \\
\hline & & Caulinita & - & - & 1 & 5 & 5 & 11 \\
\hline & & Esmectita & - & - & - & $=$ & 2 & 2 \\
\hline & & $\Sigma$ & 675 & 257 & 7 & 23 & 14 & 976 \\
\hline
\end{tabular}

1) Flogopita-biotita rioctaédrica e ilita na fração argila;

2) Predomina albita até andesita;

3) A diferença para 1000 atribui-se a: minerais pesados, opacos e indeterminados. 
Tabela 14. Mineralogia do perfil 4 ( NCL), em \% de peso da terra fina $<2 \mathrm{~mm}$ ( $\mathrm{g} \mathrm{kg}^{-1}$ ).

Tamanho da fração $(\mu \mathrm{m})$

Horiz. Prof.(cm) Tipo de Mineral $>200 \quad 200-53 \quad 53-20 \quad 20-2 \quad<2 \quad \Sigma$

\begin{tabular}{|c|c|c|c|c|c|c|c|c|}
\hline \multirow{6}{*}{ A } & \multirow{6}{*}{$0-15$} & Quartzo & 370 & 260 & 6 & 54 & - & 690 \\
\hline & & Plagioclásio ${ }^{1}$ & 20 & 35 & 3 & 43 & - & 101 \\
\hline & & Biotita $^{2}$ & 6 & 28 & 1 & 33 & - & 68 \\
\hline & & Caulinita $^{3}$ & - & - & 1 & 30 & 47 & 78 \\
\hline & & Vermiculita & - & - & - & - & 44 & 44 \\
\hline & & $\Sigma$ & 396 & 323 & 11 & 160 & 91 & $981^{4}$ \\
\hline \multirow{7}{*}{$\mathrm{Bt}$} & \multirow{7}{*}{$15-30$} & Quartzo & 200 & 88 & 4 & 30 & - & 322 \\
\hline & & Plagioclásio & 7 & 11 & 2 & 34 & - & 54 \\
\hline & & Biotita & 49 & 76 & 3 & 26 & - & 154 \\
\hline & & Caulinita & - & - & 4 & 76 & 260 & 340 \\
\hline & & Esmectita & - & - & - & - & 50 & 50 \\
\hline & & Vermiculita & - & - & - & - & 60 & 60 \\
\hline & & $\Sigma$ & 256 & 175 & 13 & 166 & 370 & 980 \\
\hline \multirow{6}{*}{$\mathrm{Cr}$} & \multirow{6}{*}{$30-40$} & Quartzo & 220 & 87 & 3 & 20 & - & 330 \\
\hline & & Plagioclásio & 9 & 12 & 2 & 20 & - & 43 \\
\hline & & Biotita & 190 & 120 & 3 & 21 & - & 334 \\
\hline & & Caulinita & - & - & 2 & 27 & 170 & 199 \\
\hline & & Vermiculita & - & - & - & - & 70 & 70 \\
\hline & & $\Sigma$ & 419 & 219 & 9 & 88 & 240 & 976 \\
\hline
\end{tabular}

1) Preponderantemente albita, até andesita;

2) Flogopita-biotita nas frações areia e silte;

3) Na fração silte, em parte, pseudomorfose de biotita para caulinita;

4) A diferença para 1000 está associada a minerais pesados, partículas opacas e indeterminadas. 
Tabela 15. Mineralogia do perfil 5 ( $\mathrm{NCv}$ ), em $\%$ de peso da terra fina $<2 \mathrm{~mm}\left(\mathrm{~g} \mathrm{~kg}^{-1}\right)$.

Tamanho da fração $(\mu \mathrm{m})$

Horiz. Prof.(cm) Tipo de Mineral >200 $200-53 \quad 53-20 \quad 20-2 \quad<2 \quad \Sigma$

\begin{tabular}{|c|c|c|c|c|c|c|c|c|}
\hline \multirow{7}{*}{$\mathrm{BA}$} & \multirow{7}{*}{$0-35$} & Quartzo & 85 & 34 & - & 55 & - & 174 \\
\hline & & Hornblenda & 60 & 240 & 7 & 33 & - & 340 \\
\hline & & Pseudomorfose $^{1}$ & 10 & 4 & 3 & - & - & 17 \\
\hline & & Plagioclásio ${ }^{2}$ & 25 & 65 & 2 & 34 & - & 126 \\
\hline & & Caulinita & - & 4 & 3 & 84 & 170 & 261 \\
\hline & & Esmectita & - & - & - & - & 80 & 80 \\
\hline & & $\Sigma$ & 180 & 347 & 15 & 206 & 250 & $998^{3}$ \\
\hline \multirow{7}{*}{$\mathrm{Bt}$} & \multirow{7}{*}{$35-60$} & Quartzo & 80 & 32 & - & 23 & - & 135 \\
\hline & & Hornblenda & 92 & 160 & 5 & 28 & - & 285 \\
\hline & & Pseudomorfose & 14 & 50 & 15 & - & - & 79 \\
\hline & & Plagioclásio & 11 & 17 & 3 & 28 & - & 59 \\
\hline & & Caulinita & - & 20 & 2 & 150 & 180 & 352 \\
\hline & & Esmectita & - & - & - & - & 78 & 78 \\
\hline & & $\bar{\Sigma}$ & 197 & 279 & 25 & 229 & 258 & 988 \\
\hline \multirow{7}{*}{$\mathrm{BC}$} & \multirow{7}{*}{$60-75$} & Quartzo & 91 & 19 & - & - & - & 110 \\
\hline & & Hornblenda & 110 & 180 & 5 & 40 & - & 335 \\
\hline & & Pseudomorfose & 10 & 130 & 16 & - & - & 156 \\
\hline & & Plagioclásio & 12 & 22 & 2 & 40 & - & 76 \\
\hline & & Caulinita & - & 15 & 2 & 155 & 65 & 237 \\
\hline & & Esmectita & - & - & - & - & 50 & 50 \\
\hline & & $\Sigma$ & 223 & 366 & 25 & 235 & 115 & 964 \\
\hline \multirow{7}{*}{$\mathrm{Cr}$} & \multirow{7}{*}{$75+$} & Quartzo & 83 & 14 & - & - & - & 97 \\
\hline & & Hornblenda & 430 & 172 & 5 & 20 & - & 627 \\
\hline & & Pseudomorfose & 10 & 136 & 9 & - & - & 155 \\
\hline & & Plagioclásio & 25 & 19 & 2 & 8 & - & 54 \\
\hline & & Caulinita & - & 15 & 2 & 31 & 3 & 51 \\
\hline & & Esmectita & - & - & - & - & 5 & 5 \\
\hline & & $\Sigma$ & 548 & 356 & 18 & 59 & 8 & 989 \\
\hline
\end{tabular}

1) Pseudomorfoses de homblendas para minerais de argila;

2) Preponderantemente albita;

3) A diferença para 1000 está associada a minerais pesados, particulas opacas e indeterminadas. 

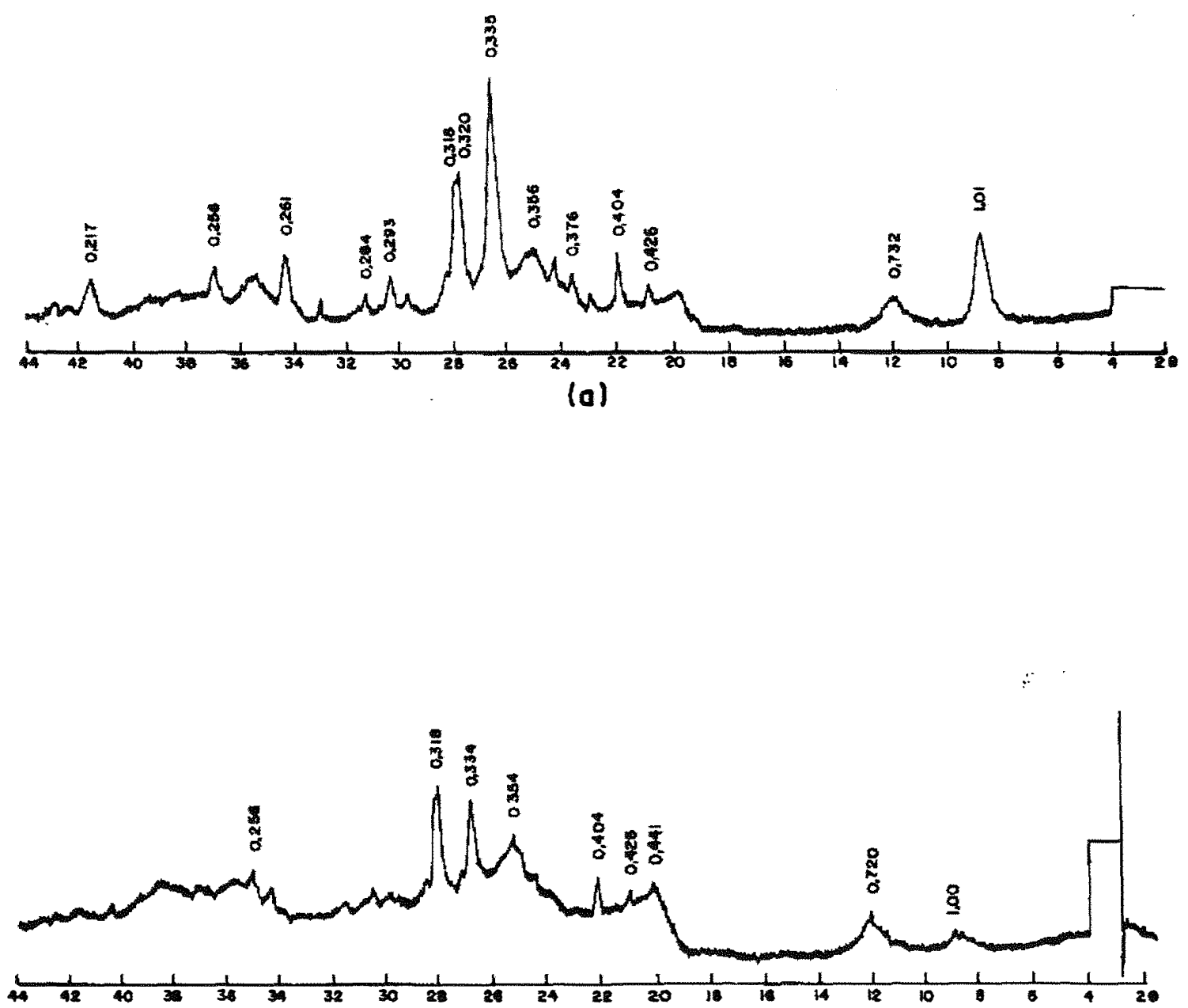

(b)

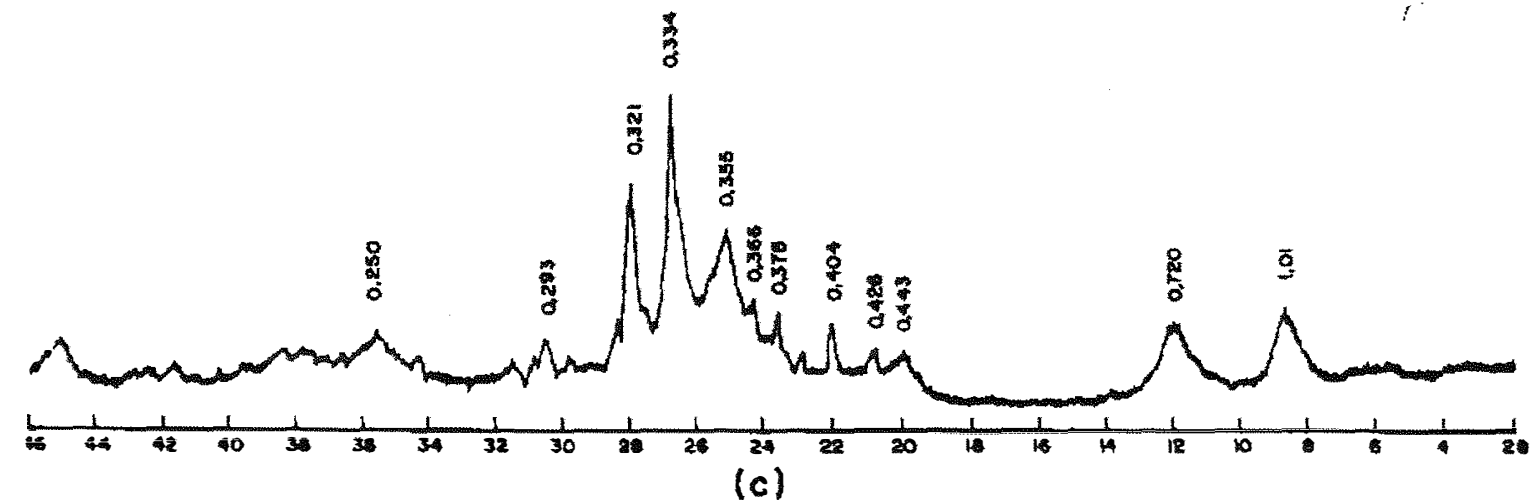

Figura 12 - Difratogramas da fração silte fino do perfil 3 (NC). (a)horizonte A; (b) horizonte $\mathrm{Bt}$ e (c) horizonte $\mathrm{Cr}$ (tratamentos $\operatorname{com~K} \mathrm{K}^{+}$a $25^{\circ} \mathrm{C}$ ) 

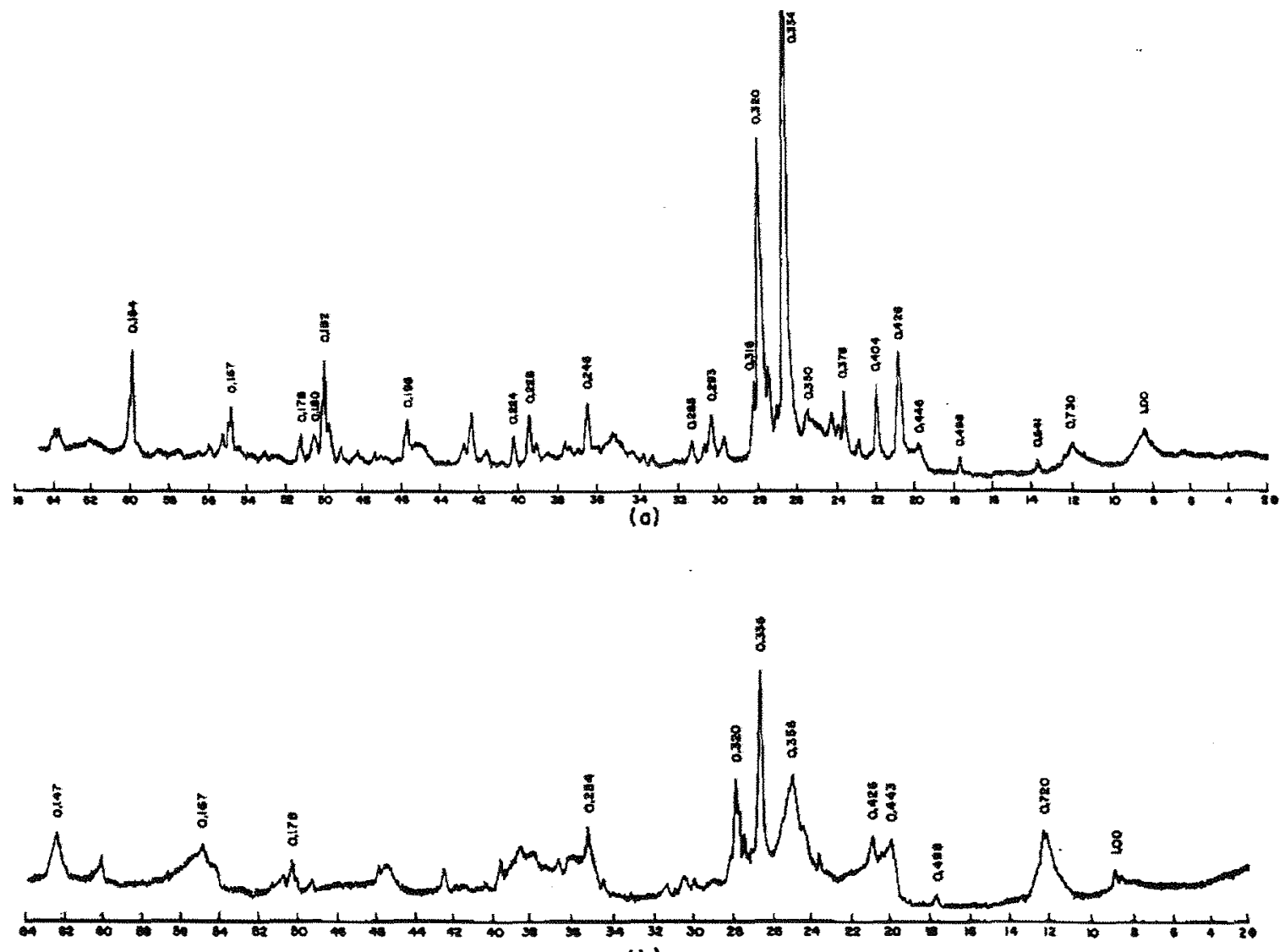

(b)

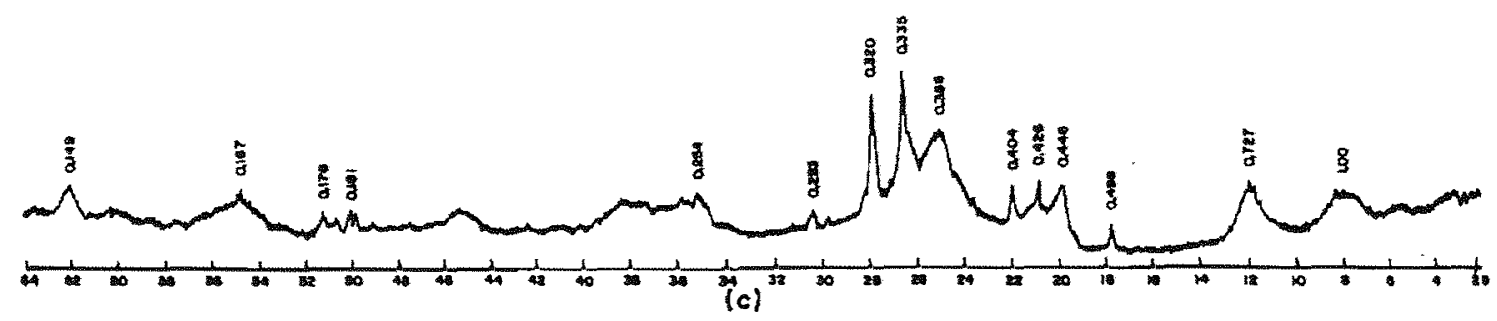

Figura 13 - Difratogramas da fração silte fino do perfil 4 (NCL). (a) ho rizonte $\mathrm{A}$; (b) horizonte $\mathrm{Bt}$ e (c) horizonte $\mathrm{Cr}$ (tratamentos com $\mathrm{K}^{+}$a $25^{\circ} \mathrm{C}$ ). 


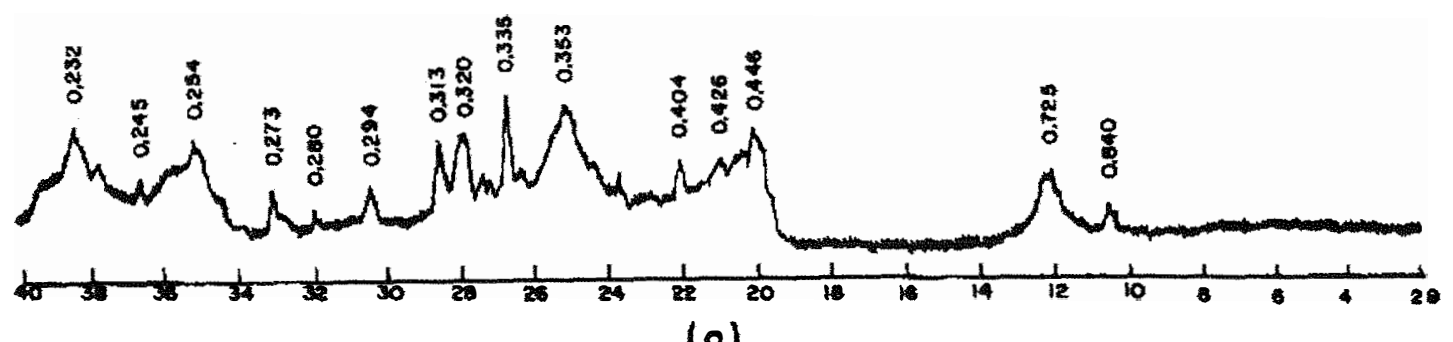

(a)
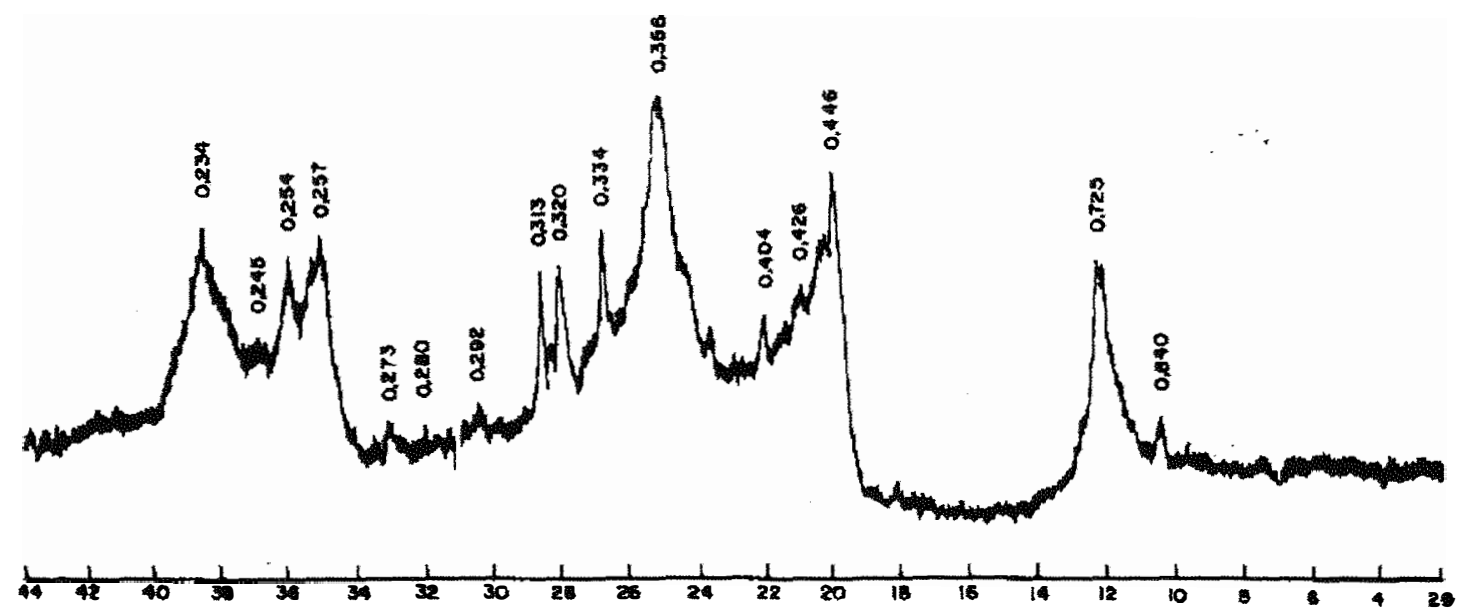

(b)

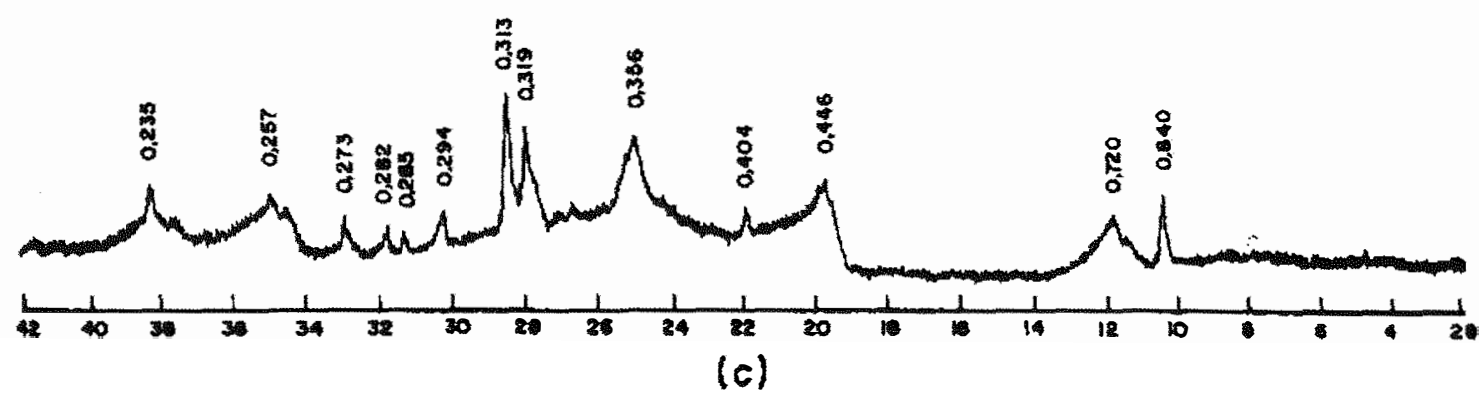

Figura 14 - Difratogramas da fração silte fino do perfil 5 (NCv). (a) ho rizonte $\mathrm{BA}$; (b) horizonte $\mathrm{Bt}$ e (c) horizonte $\mathrm{Cr}$ (tratamen tos com $\mathrm{K}^{+}$a $25^{\circ} \mathrm{C}$ ). 


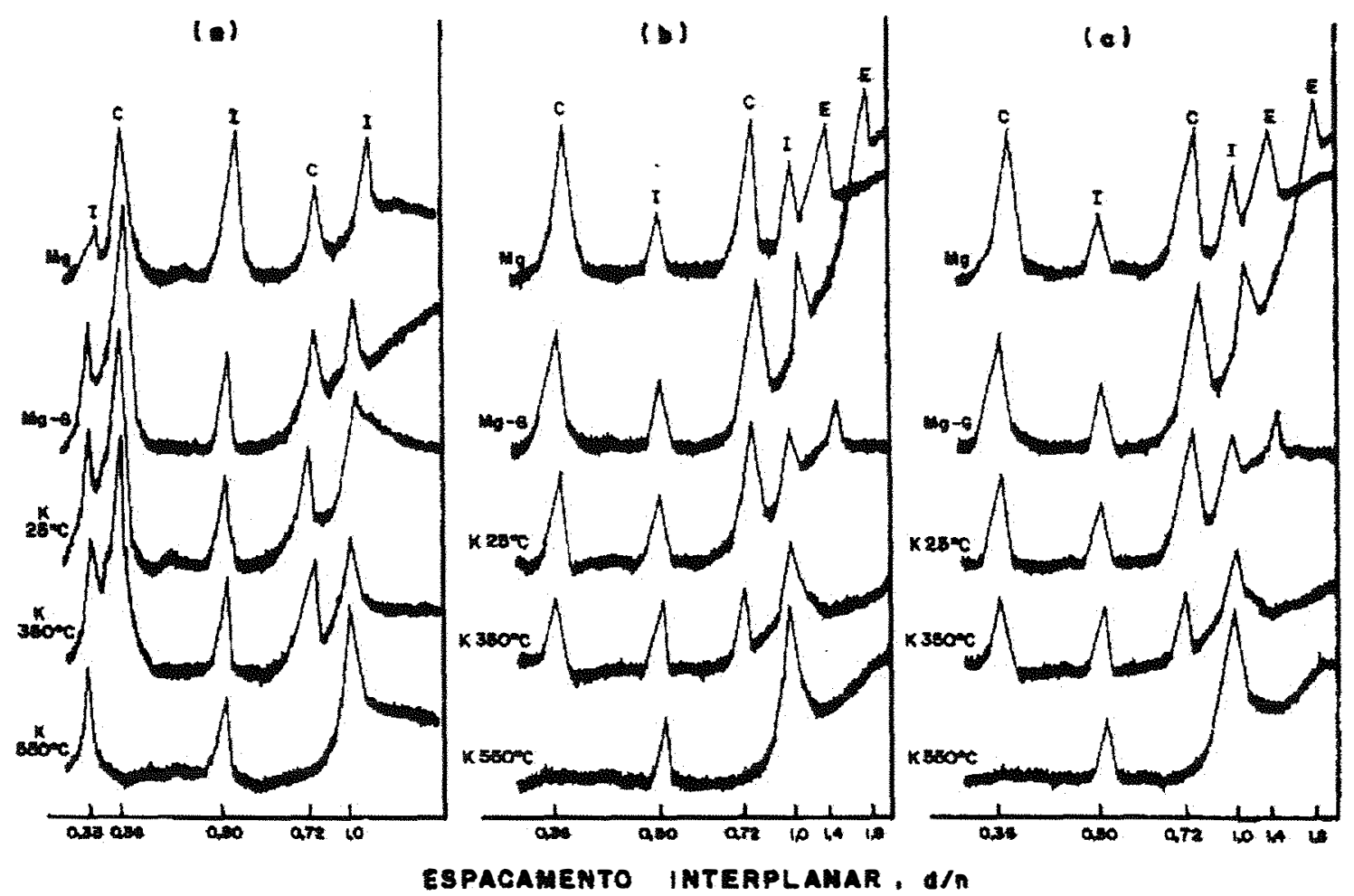

Figura 15 - Difratogramas da fração argila do perfil 3 (NC). (a) horizonte A; (b) horizon te $\mathrm{Bt}$ e (c) horizonte $\mathrm{Cr}$ (amostra orientada).

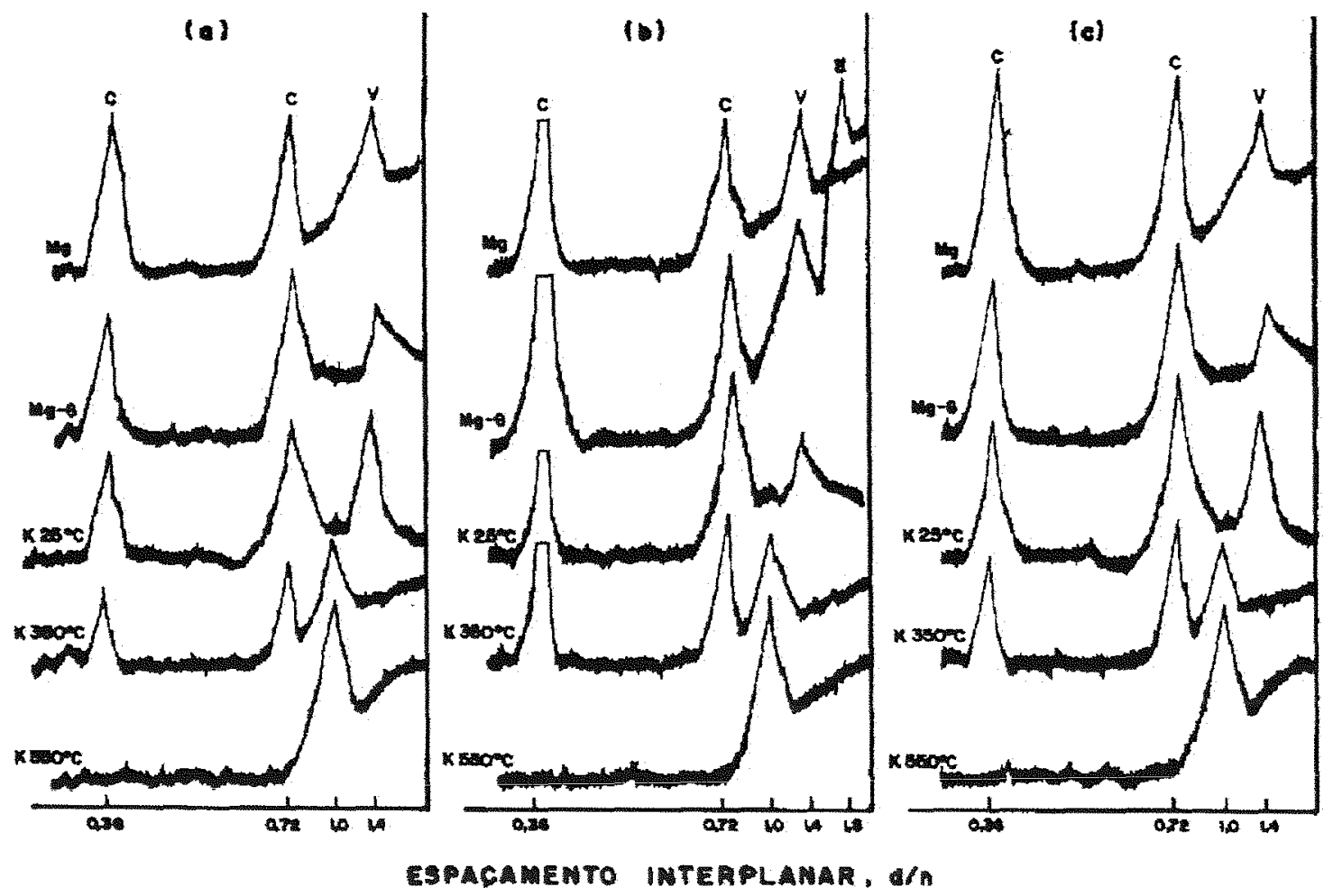

Figura 16 - Difratogramas da fração argila do perfil 4 (NCL). (a) horizonte A; (b) ho rizonte $\mathrm{Bt}$ e (c) horizonte $\mathrm{Cr}$ (amostra orientada). 


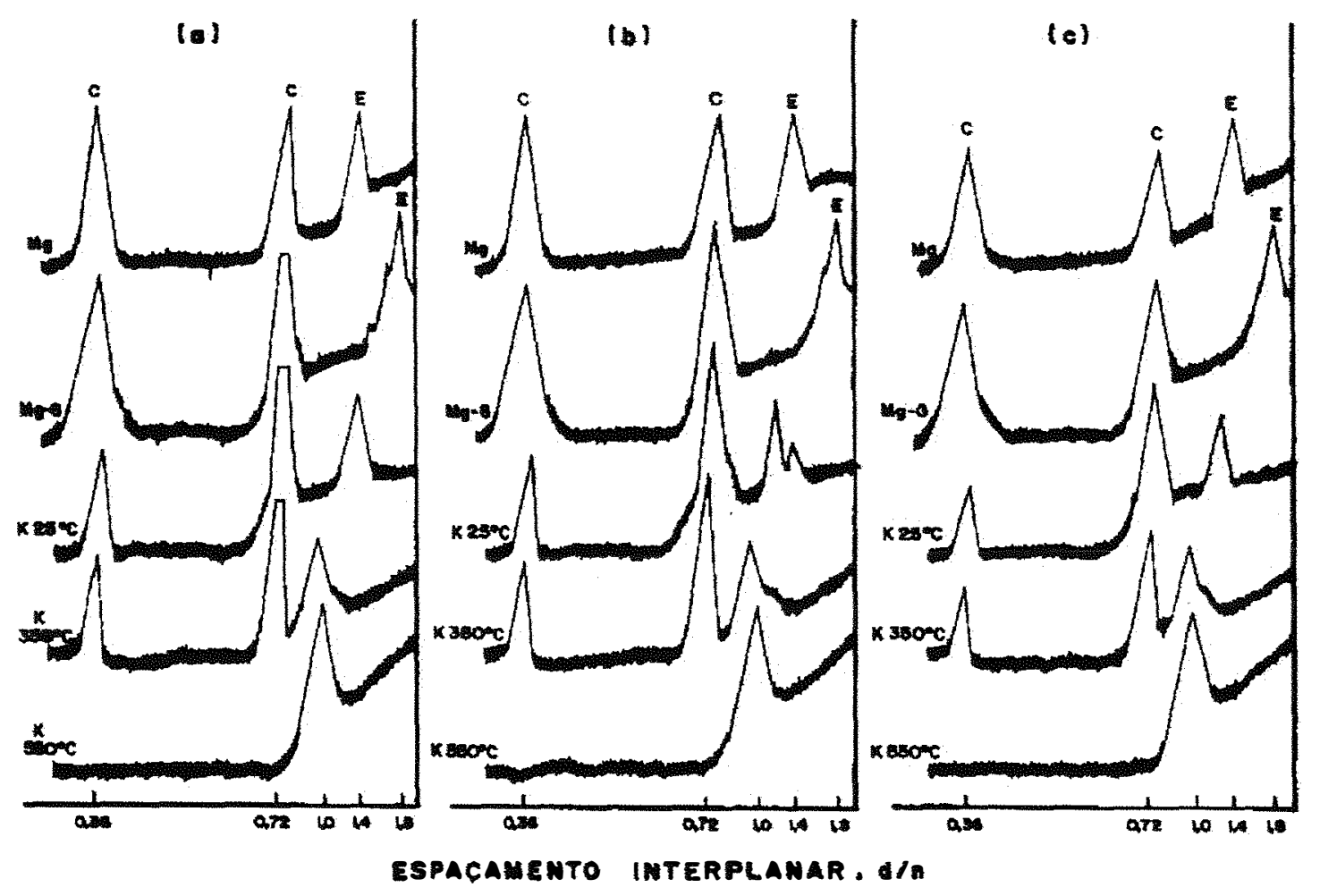

Figura 17 - Difratogramas da fração argila do perfil $5(\mathrm{NCv})$. (a) hori zonte BA; (b) horizonte Bt e (c) horizonte $\mathrm{Cr}$ (Am. orientada).

B - Fração argila

A fração argila de todos os perfis (figuras 15, 16 e 17), apresenta a caulinita como argilo-mineral predominante. No $\mathrm{NCv}$ as quantidades de montmorilonita são maiores do que nos outros perfis, fato esse associado com as suas condições de drenagem. No $\mathrm{NC}$ e NCL constatou-se também a presença de ilita e vermiculita, transformadas a partir de mica (flogopita-biotita). Sousa (1986), também estudando a mineralogia de solos Brunos Não-Cálcicos do Estado de Pernambuco, encontrou a caulinita e a 
Tabela 16. Mineralogia do perfil 6 ( $\mathrm{PEa}$ ), em $\%$ de peso da terra fina $<2 \mathrm{~mm}\left(\mathrm{~g} \mathrm{~kg}^{-1}\right)$.

$$
\text { Tamanho da fração }(\mu \mathrm{m})
$$

Horiz. Prof.(cm) Tipo de Mineral $>200 \quad 200-53 \quad 53-20 \quad 20-2 \quad<2 \quad \sum$

\begin{tabular}{|c|c|c|c|c|c|c|c|c|}
\hline \multirow{7}{*}{$\mathrm{AB}$} & \multirow{7}{*}{$0-40$} & Quartzo & 215 & 50 & 29 & 55 & 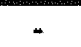 & 349 \\
\hline & & Plagioclásio $^{1}$ & 129 & 33 & 13 & - & - & 175 \\
\hline & & Biotita & 22 & 11 & 3 & - & - & 36 \\
\hline & & Muscovita & 65 & 17 & 8 & 22 & - & 112 \\
\hline & & Caulinita & - & - & - & 22 & 261 & 283 \\
\hline & & Ilita & - & - & - & 11 & 29 & 40 \\
\hline & & $\Sigma$ & 431 & 111 & 53 & 110 & 290 & $995^{3}$ \\
\hline \multirow{7}{*}{$2 \mathrm{Bt} 1$} & \multirow{7}{*}{$40-70$} & Quarzo & 50 & 18 & 7 & 29 & 47 & 151 \\
\hline & & Pseudomorfose $^{2}$ & 74 & 33 & 27 & - & - & 134 \\
\hline & & Biotita & 93 & 26 & 10 & - & - & 129 \\
\hline & & Muscovita & 93 & 33 & 24 & - & - & 150 \\
\hline & & Caulinita & - & - & - & 134 & 233 & 367 \\
\hline & & Ilita & - & - & - & 29 & 31 & 60 \\
\hline & & $\Sigma$ & 310 & 110 & 68 & 192 & 311 & 991 \\
\hline \multirow{6}{*}{$2 \mathrm{Bt} 2$} & \multirow{6}{*}{$70-100$} & Quarzo & 51 & 13 & 07 & 30 & 41 & 142 \\
\hline & & Pseudomorfose & 85 & 40 & 31 & - & - & 156 \\
\hline & & Biotita & 102 & 22 & 10 & - & - & 134 \\
\hline & & Muscovita & 102 & 35 & 21 & - & - & 158 \\
\hline & & Caulinita & - & - & - & 150 & 203 & 353 \\
\hline & & Ilita & - & - & - & 20 & 27 & 47 \\
\hline \multirow{8}{*}{$2 \mathrm{BC}$} & \multirow{8}{*}{$100-130$} & $\Sigma$ & 340 & 110 & 69 & 200 & 271 & 990 \\
\hline & & Quartzo & 65 & 19 & 12 & 19 & 29 & 144 \\
\hline & & Pseudomorfose & 108 & 25 & 19 & - & - & 152 \\
\hline & & Biotita & 129 & 30 & 23 & - & - & 182 \\
\hline & & Muscovita & 129 & 30 & 23 & - & - & 182 \\
\hline & & Caulinita & - & - & - & 153 & 143 & 296 \\
\hline & & Ilita & - & - & - & 19 & 19 & 38 \\
\hline & & $\Sigma$ & 431 & 104 & 77 & 191 & 191 & 994 \\
\hline \multirow{8}{*}{$2 \mathrm{CB}$} & \multirow{8}{*}{$\begin{array}{l}130- \\
190+\end{array}$} & Quartzo & 66 & 24 & 15 & 30 & - & 135 \\
\hline & & Biotita & 154 & 56 & 34 & - & - & 244 \\
\hline & & Muscovita & 154 & 56 & 34 & - & - & 244 \\
\hline & & Plagioclásio & 44 & 16 & 10 & - & - & 70 \\
\hline & & Pseudomorfose & 22 & 8 & 5 & - & - & 35 \\
\hline & & Caulinita & 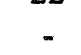 & - & - & 150 & 81 & 231 \\
\hline & & Ilita & - & - & - & 20 & 20 & 40 \\
\hline & & $\Sigma$ & 440 & 160 & 98 & 200 & 101 & 999 \\
\hline
\end{tabular}

1) Predominantemente albita;

2) Pseudomorfose de feldspato para caulinita;

3) A diferença para 1000 está associada a minerais opacos, pesados e indeterminados. 
Tabela 17. Mineralogia do perfil 7 ( $\mathrm{PVa}$ ), em $\%$ de peso da terra fina $<2 \mathrm{~mm}\left(\mathrm{~g} \mathrm{~kg}^{-1}\right)$.

\begin{tabular}{|c|c|c|c|c|c|c|c|c|}
\hline \multirow[b]{2}{*}{ Horiz. } & \multirow[b]{2}{*}{ Prof.(cm) } & \multicolumn{7}{|c|}{ Tamanho da fração $(\mu \mathrm{m})$} \\
\hline & & $\begin{array}{l}\text { Tipo de } \\
\text { Mineral }\end{array}$ & $>200$ & $200-53$ & $53-20$ & $20-2$ & $<2$ & $\Sigma$ \\
\hline \multirow{7}{*}{$\mathrm{AB}$} & \multirow{7}{*}{$0-40$} & Quartzo & 60 & 21 & 08 & 9 & - & 98 \\
\hline & & Biotita ${ }^{1}$ & 120 & 78 & 13 & - & - & 211 \\
\hline & & Muscovita & 140 & 109 & 27 & - & - & 276 \\
\hline & & Plagioclásio $^{2}$ & 80 & 52 & 13 & - & - & 145 \\
\hline & & Ilita & - & - & - & 34 & 86 & 120 \\
\hline & & Caulinita & - & - & - & 43 & 105 & 148 \\
\hline & & $\sum$ & 400 & 260 & 61 & 86 & 191 & $998^{3}$ \\
\hline \multirow{9}{*}{ Btfl } & \multirow{9}{*}{$40-90$} & Quartzo & 52 & 14 & 8 & 7 & - & 81 \\
\hline & & Biotita & 130 & 35 & 20 & - & - & 185 \\
\hline & & Muscovita & 234 & 56 & 32 & - & - & 322 \\
\hline & & Plagioclásio & 104 & 28 & 16 & - & - & 148 \\
\hline & & Ilita & - & - & - & 26 & 76 & 102 \\
\hline & & Caulinita & - & - & - & 29 & 114 & 143 \\
\hline & & Lepidocrocita & - & 2 & 1 & 1 & - & 4 \\
\hline & & Goetita & - & 4 & 2 & 2 & - & 8 \\
\hline & & $\Sigma$ & 520 & 140 & 79 & 65 & 190 & 994 \\
\hline \multirow{9}{*}{ Btf2 } & \multirow{9}{*}{$90-130$} & Quartzo & 57 & 17 & 11 & 15 & - & 100 \\
\hline & & Biotita & 76 & 43 & 28 & - & - & 147 \\
\hline & & Muscovita & 171 & 59 & 44 & - & - & 274 \\
\hline & & Plagioclásio & 76 & 43 & 28 & - & - & 147 \\
\hline & & Ilita & - & - & - & 35 & 92 & 127 \\
\hline & & Caulinita & - & - & - & 50 & 138 & 188 \\
\hline & & Lepidocrocita & - & 3 & 2 & - & - & 5 \\
\hline & & Goetita & - & 5 & 4 & - & - & 9 \\
\hline & & $\Sigma$ & 380 & 170 & 117 & 100 & 230 & 997 \\
\hline \multirow{9}{*}{$\mathrm{CB}$} & \multirow{9}{*}{$130-180$} & Quartzo & 51 & 19 & 9 & 15 & - & 94 \\
\hline & & Biotita & 179 & 67 & 39 & - & - & 285 \\
\hline & & Muscovita & 138 & 51 & 27 & - & - & 216 \\
\hline & & Plagioclásio & 143 & 53 & 31 & - & - & 227 \\
\hline & & Ilita & - & - & - & 40 & 48 & 88 \\
\hline & & Caulinita & - & - & - & 45 & 48 & 93 \\
\hline & & Lepidocrocita & - & - & 3 & - & - & 3 \\
\hline & & Goetita & - & - & 2 & $=$ & - & 2 \\
\hline & & $\sum$ & 511 & 190 & 111 & 100 & 96 & 1008 \\
\hline \multirow{9}{*}{$\mathrm{Cr}$} & \multirow{9}{*}{$180-250+$} & Quartzo & 49 & 17 & 9 & 10 & - & 85 \\
\hline & & Biotita & 226 & 78 & 34 & 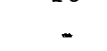 & - & 338 \\
\hline & & Muscovita & 183 & 63 & 24 & - & - & 270 \\
\hline & & Plagioclásio & 153 & 53 & 23 & - & - & 229 \\
\hline & & Ilita & - & - & - & 28 & 11 & 39 \\
\hline & & Caulinita & - & - & - & 32 & 11 & 43 \\
\hline & & Lepidocrocita & - & - & 2 & - & - & 2 \\
\hline & & Goetita & - & - & 3 & - & - & 3 \\
\hline & & $\Sigma$ & 611 & 211 & 95 & 70 & 22 & 1009 \\
\hline
\end{tabular}

1) Flogopita-biotita ;

2) Predominantemente albita;

3) A diferença para 1000 está associada a minerais opacos e indetenninados. 
montmorilonita como sendo os minerais secundários predominantes na fração argila dos citados solos.

Luz et al. (1992), verificaram a ocorrência de vermiculita, montmorilonita e caulinita nesses mesmos solos, com a caulinita aumentando e a montmorilonita diminuindo em direção à superfície.

\subsubsection{Solos de Guaramiranga}

A - Frações areia e silte

A mineralogia dessas frações nos dois perfis PEa e PVa (tabelas 16 e 17), indica a ocorrência de biotita, muscovita, quartzo e plagioclásios, com predominância das micas principalmente nos horizontes inferiores. No perfil 6, já são visíveis na areia e silte grosso, pseudomorfoses de feldspato para caulinita e no perfil 7 na areia fina e silte grosso do horizonte Btf, pequenas quantidades de goetita e lepidocrocita, que podem ser sugestivos do início do processo de plintização. No silte fino, em ambos os solos, ocorrem minerais secundários como ilita e caulinita além de quartzo. No PEa de melhor drenagem e localizado na vertente úmida da serra, a caulinita é dominante e aumenta em direção a superfície. No PVa com alguma restrição de drenagem e posicionado na vertente seca a uma menor altitude ( figura 6, pg. 52 ), as proporções de ilita e caulinita são muito semelhantes. As figuras 18 e 19 apresentam os difratogramas do silte fino nos dois perfis. Esses resultados concordam em parte, com os citados em Brasil (1973) e por Ribeiro et al. (1991). 


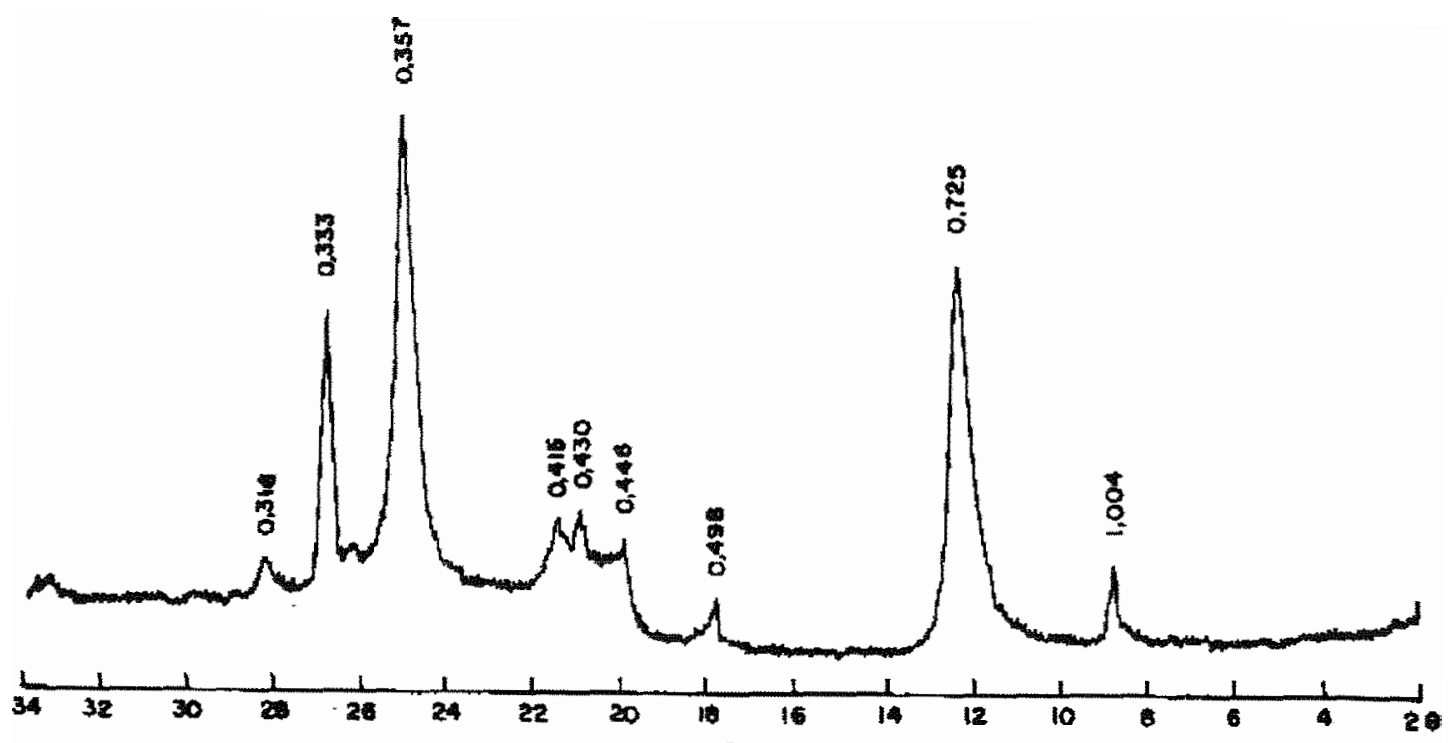

(a)

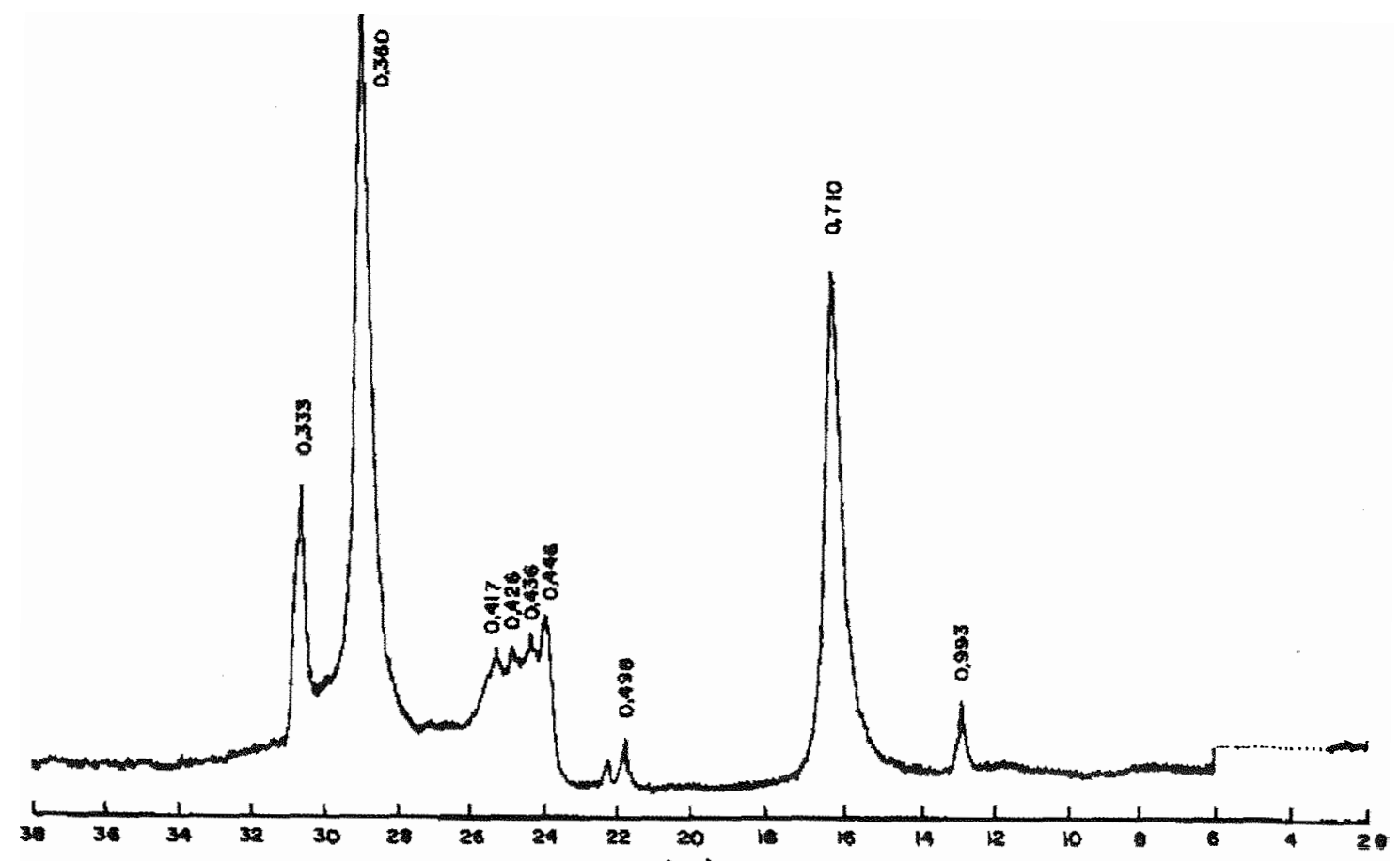

(b)

Figura 18 - Difratogramas da fração silte fino do perfil 6 (PEa). (a) horizonte $A B$; (b) horizonte $2 \mathrm{Bt} 2$ e (c) horizonte $2 \mathrm{CB}$ (tratamento com K $\mathrm{K}^{+} 25^{\circ} \mathrm{C}$ ). 


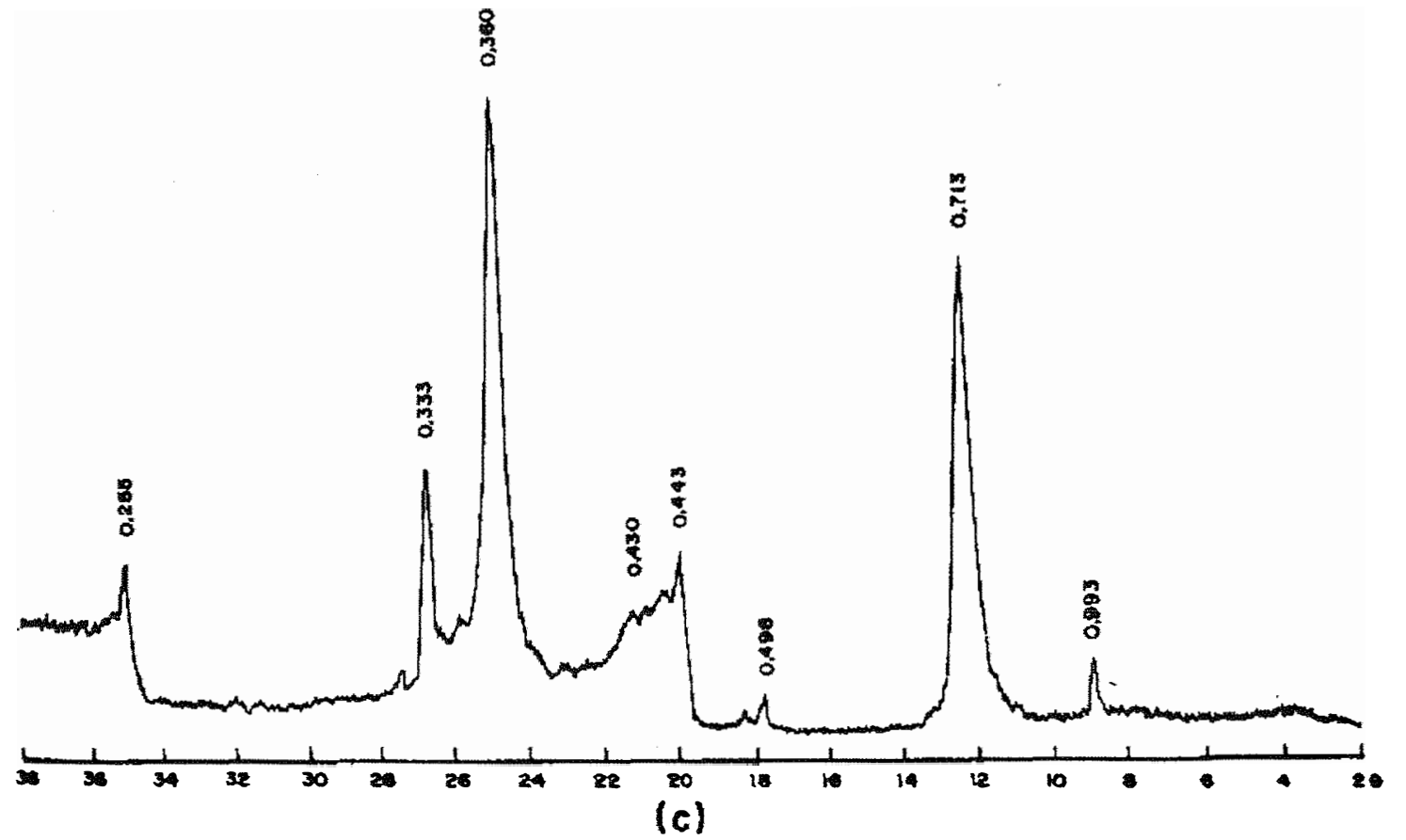

Figura 18 - Difratogramas da fração silte fino do perfil 6 (PEa). (a) horizonte AB; (b) horizonte $2 \mathrm{Bt} 2 \mathrm{e} \mathrm{(c)} \mathrm{horizonte} 2 \mathrm{CB}$ (tratamento com $\mathrm{K}^{+}$a $25^{\circ} \mathrm{C}$ ). 


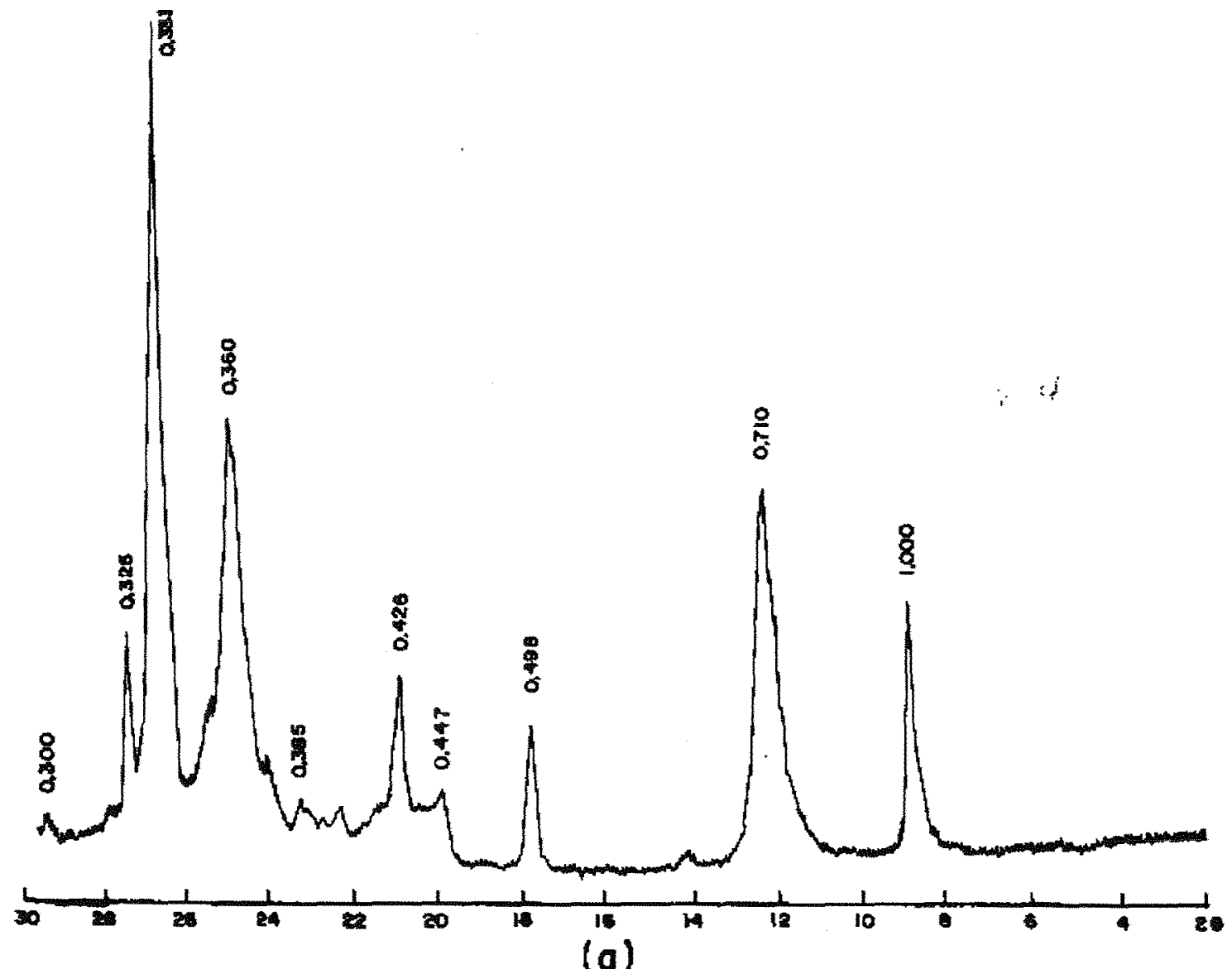

(a)

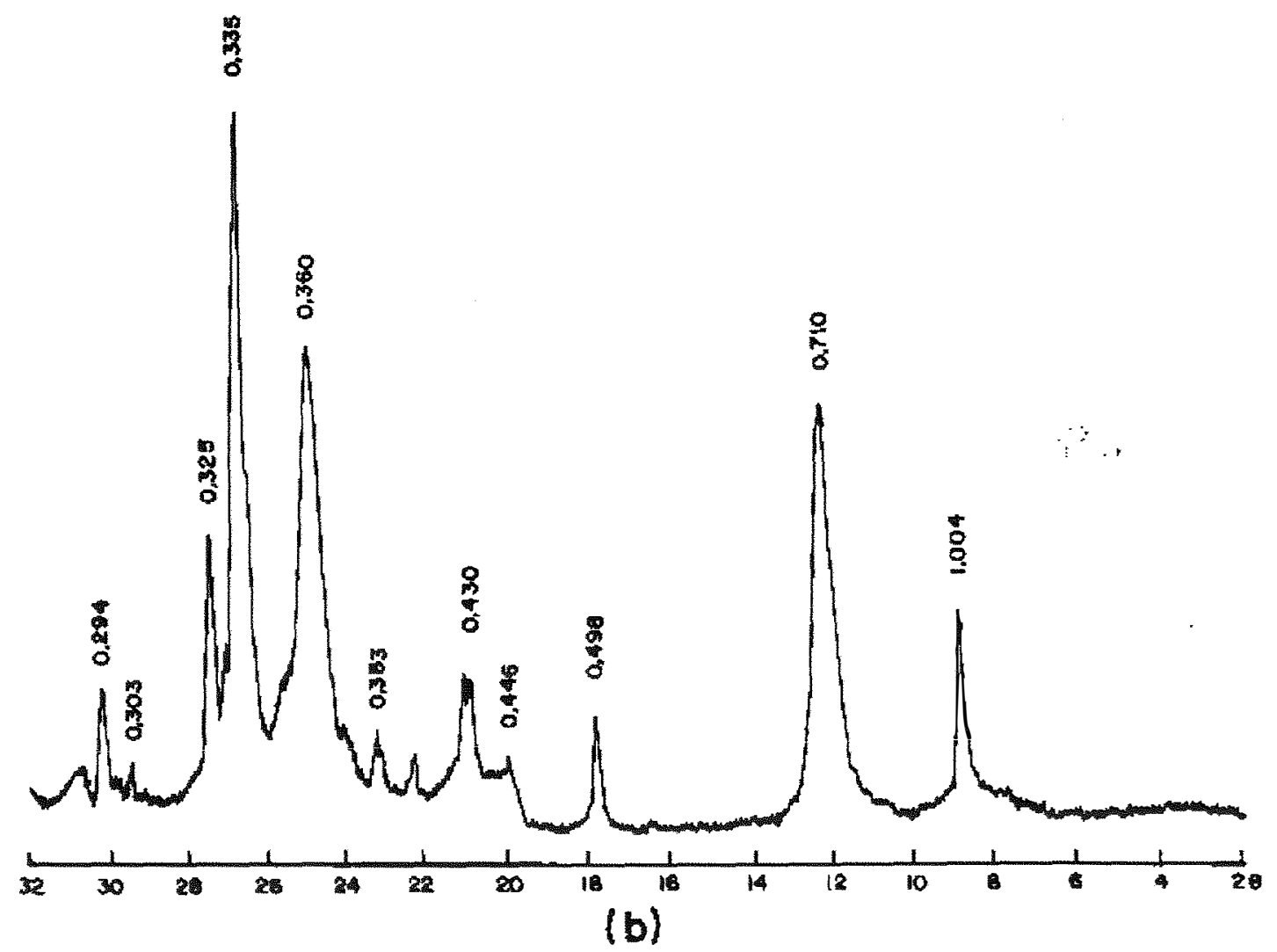

Figura 19 - Difratogramas da fração silte fino do perfil 7 (PVa). 


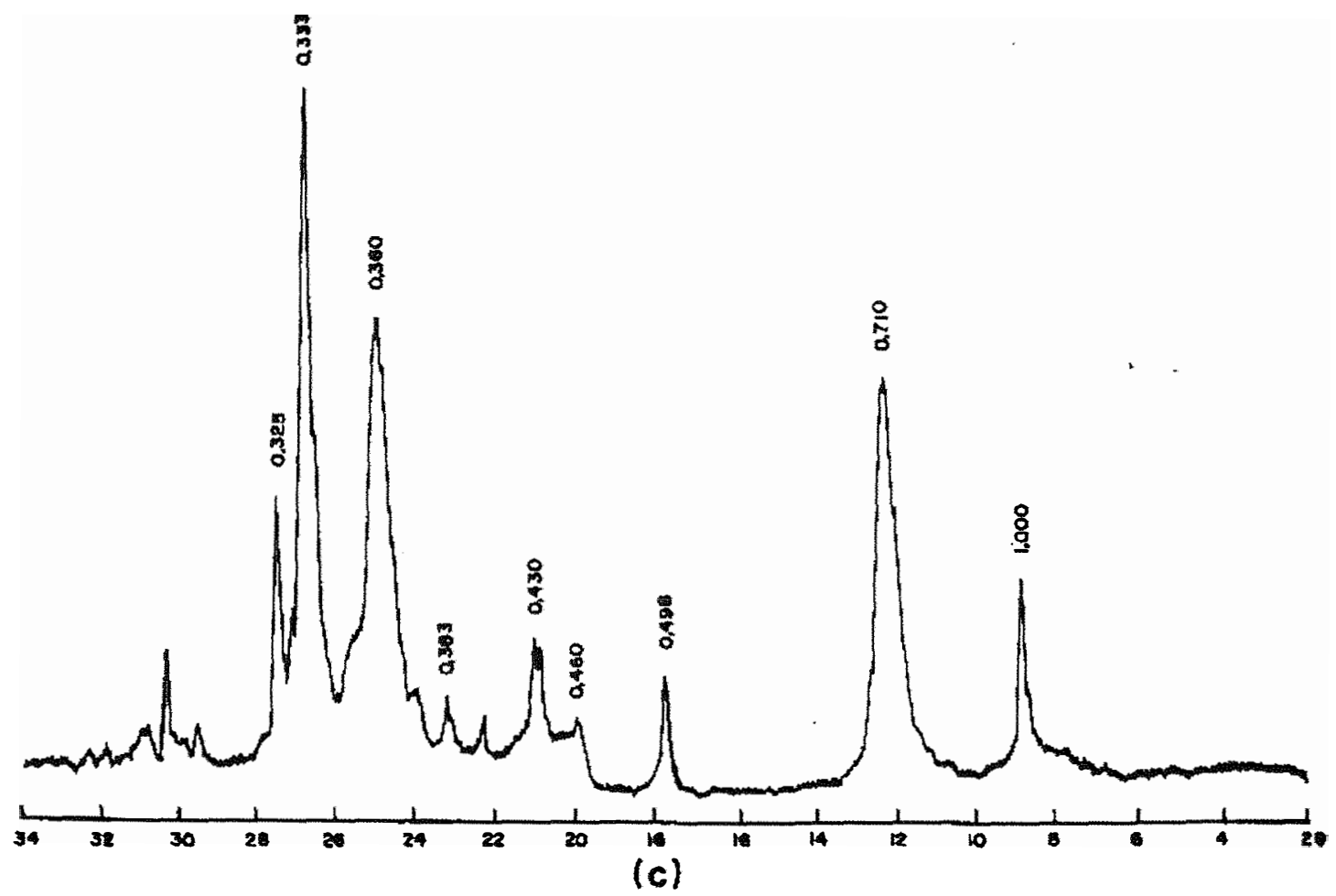

Figura 19 - Difratogramas da fração silte fino do perfil 7 (PVa). (a) horizonte AB; (b) horizonte Bt2; (c) horizonte $\mathrm{Cr}$ (tratamento com $\mathrm{K}^{+}$a $25^{\circ} \mathrm{C}$ ). 


\section{B - Fração argila}

Nessa fração há uma constância mineralógica nos dois perfis, representada pelos argilo-minerais caulinita e ilita (tabelas 16 e 17 e figuras 20 e 21). A caulinita apresenta-se em maior concentração nos dois solos, principalmente no PEa e aumenta em direção a superficie. A ilita tem uma distribuição não muito regular com a profundidade. Resultados parcialmente semelhantes em Podzólicos Vermelho-Amarelos álicos ou distróficos no Nordeste do Brasil, foram encontrados por Ribeiro et al. (1991); Costa (1994) e Alves \& Ribeiro (1995).

A tendência de maior concentração de caulinita no perfil 6 e características de maior maturidade do solo (quantidade de argila no $\mathrm{Bt}, \mathrm{V} \%$ m \%, ki e kr), estão com certeza correlacionados à maior umidade da vertente úmida e melhor drenagem do solo. Souza (1988), destaca que a disposição do relevo face ao deslocamento dos ventos condiciona a formação de chuvas orográficas nessa parte da serra. Por sua vez a vertente seca com chuvas mais escassas, tem condições ambientais que já mostram semelhanças com a depressão sertaneja dos sertões de Caridade-Canindé, com a qual faz contatos através de pedimentos.

\subsubsection{Solos de Tauá}

A - Frações areia e silte

$\mathrm{Na}$ constituição mineralógica do perfil 8 (tabela 18), predominam nessas frações plagioclásios, quartzo, biotita e hornblenda, com os teores de hornblenda e biotita caindo drasticamente ou mesmo desaparecendo do $2 \mathrm{Cr}$ 


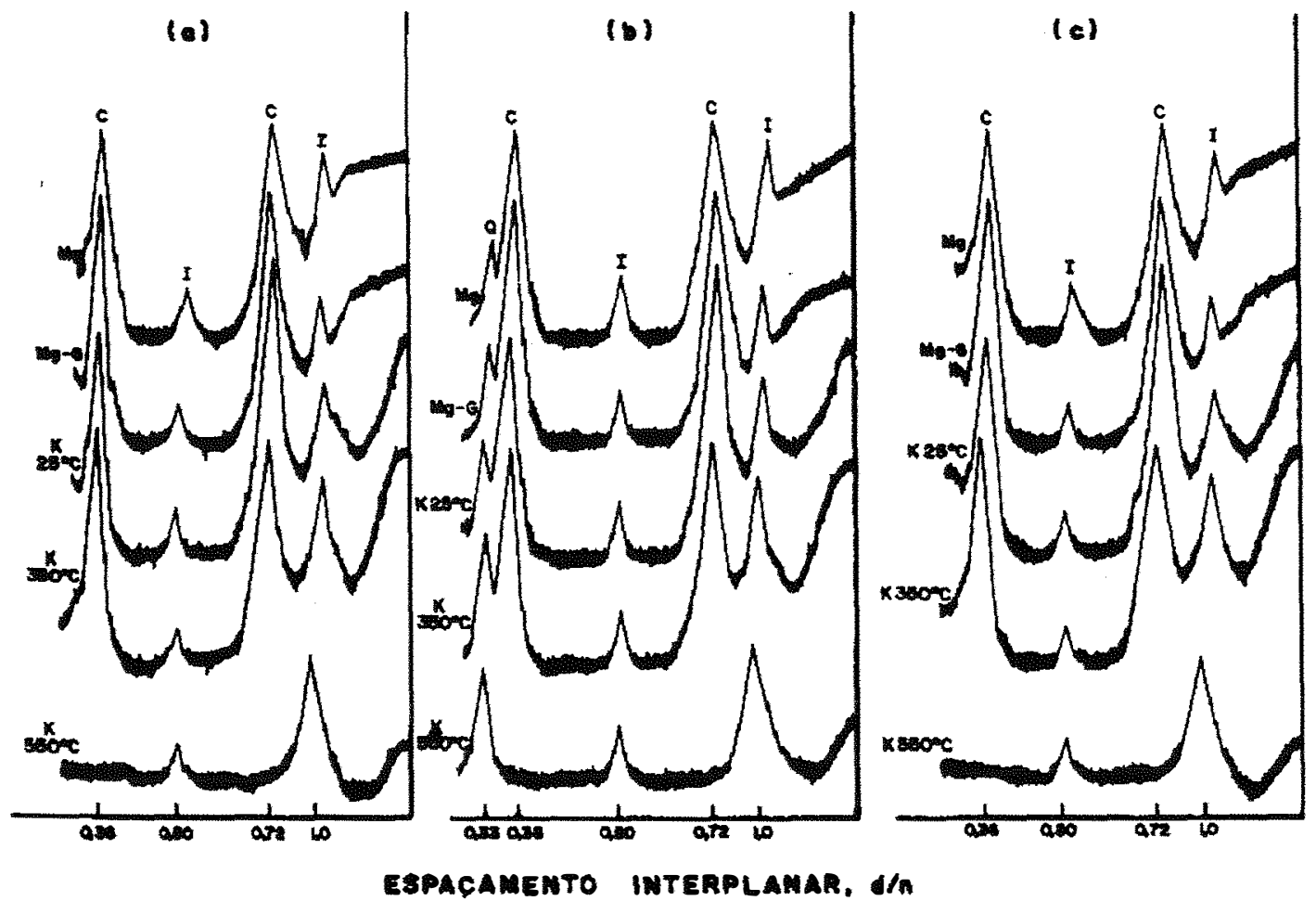

Figura 20 - Difratogramas da fração argila do perfil 6 (PEa). (a) horizonte AB; (b) ho rizonte $2 \mathrm{Bt} 2$ e (c) horizonte $2 \mathrm{CB}$ (amostra orientada).
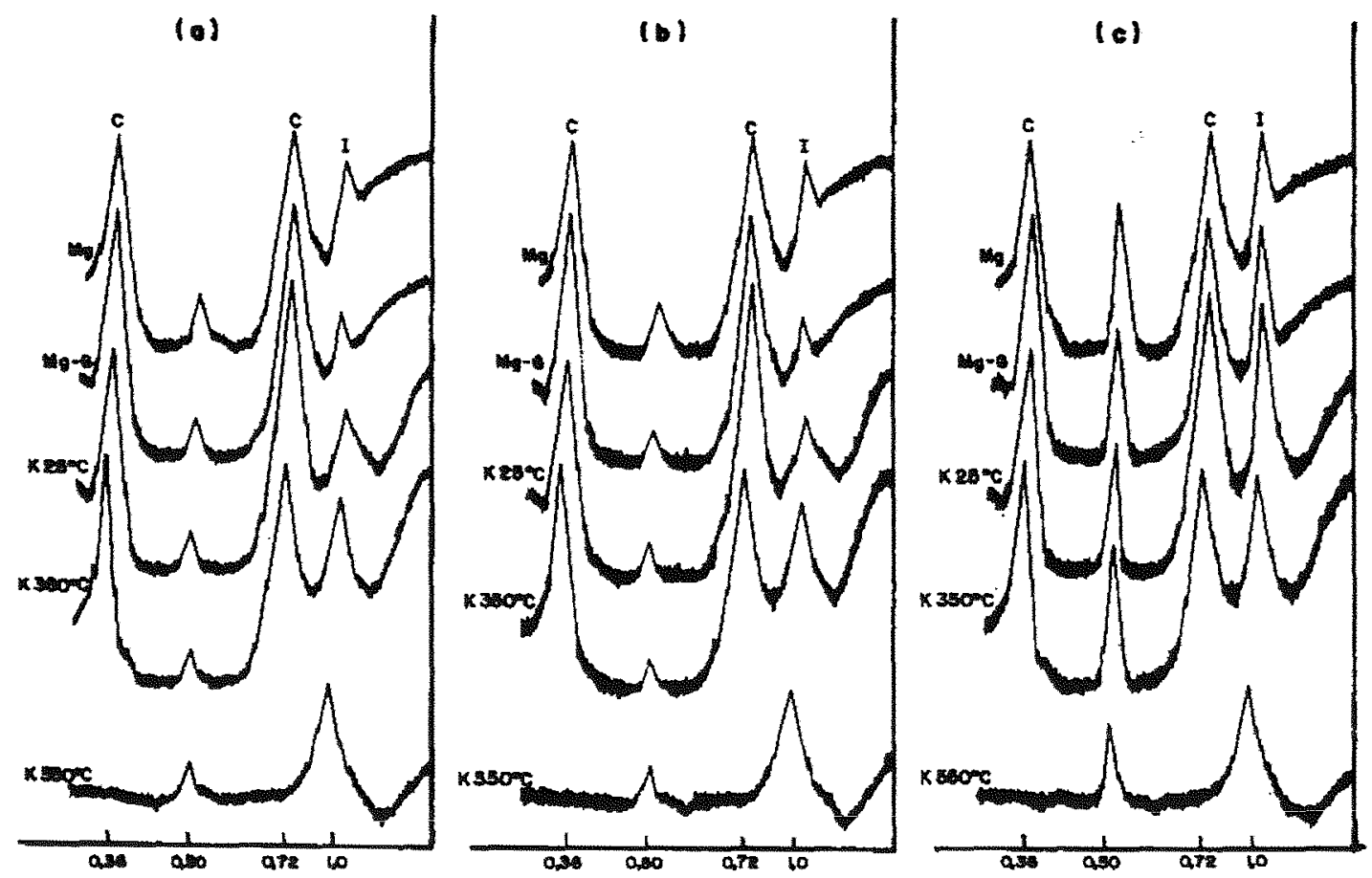

ESPACAMENTO INTERPLANAR. d/n

Figura 21 - Difratogramas da fração argila do perfil 7 (PVa). (a) horizonte $A B$; (b) ho rizonte $\mathrm{Btf2}$ e (c) horizonte $\mathrm{Cr}$ (amostra orientada). 
para o 2Btn. No silte fino, além destes já ocorrem vermiculita e caulinita. $\mathrm{O}$ solo Aluvial (AL) (anexo B), posicionado na zona de acumulação da vertente tem o quartzo como mineral predominante em todos os horizontes, seguido de plagioclásios e pouca biotita e hornblenda, com essa última já aparecendo na areia fina e silte grosso na forma de pseudomorfoses para caulinita. A irregularidade nas proporções dos principais minerais constituintes das frações areia e silte, é típica de solos aluviais estratificados, onde duas ou mais descontinuidades litológicas são quase sempre comuns. No silte fino, além dos minerais supracitados, foram detectados ainda montmorilonita e caulinita. A figura 22 mostra difratogramas da fração silte fino do perfil 8.

B - Fração argila

O elenco básico de minerais encontrados nos dois perfis na fração argila é relativamente diferente, o que até certo ponto pode ser explicado pela natureza pseudo-autóctone do perfil 8 e alóctone do solo aluvial. Enquanto no PL (tabela 18 e figura 23), esmectita, caulinita e vermiculita constituem o conjunto de argilo-minerais, concordando com Batista (1988), Costa (1994) e Góis (1995), no solo aluvial são verificadas a existência na fração argila de plagioclásios e quartzo o que demonstra o aspecto mais recente e de menor maturidade do solo da parte mais baixa do relevo. As quantidades de esmectita, vermiculita e caulinita, mostram-se também irregulares com a profundidade, sem nenhuma tendência de aumento ou decréscimo em determinada direção dentro do perfil. No PL os teores de esmectita e caulinita aumentam do horizonte $2 \mathrm{Cr}$ para o $2 \mathrm{Btn}$, enquanto que a vermiculita já não é mais encontrada nesse último horizonte. 


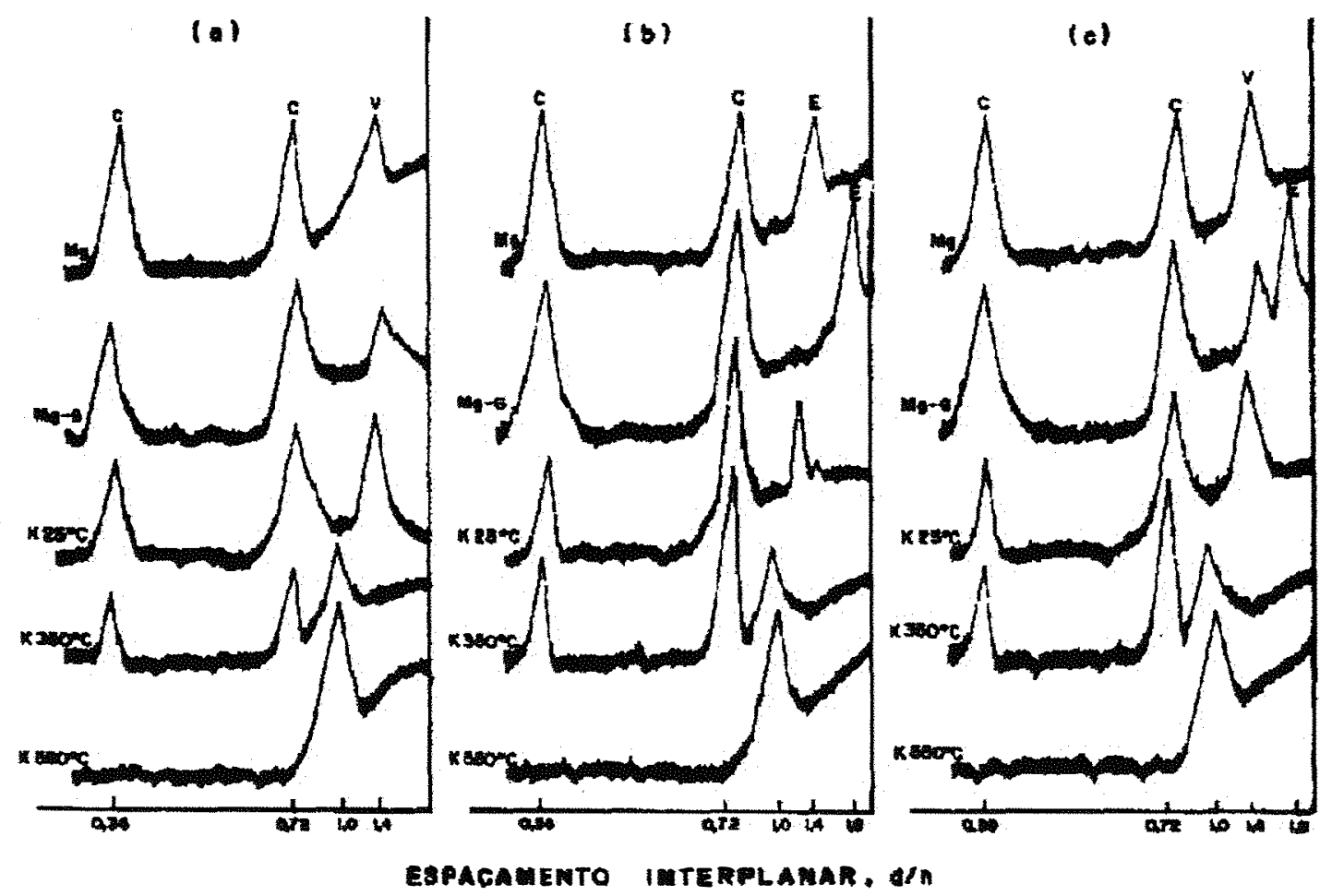

Figura 23 - Difratogramas da fração argila do perfil 8 (PL). (a) horizonte $\mathrm{A}$; (b) horizonte $2 \mathrm{Btn}$ e (c) horizonte $2 \mathrm{Cr}$ (am. orientada).

\subsubsection{Solos da BR - 222}

A - Frações areia e silte

No perfil 10 (PVe - tabela 19), derivado de granito, verifica-se a presença de feldspato, quartzo e biotita. Nos quatro horizontes mais superiores $(\mathrm{A}, \mathrm{Bt} 1, \mathrm{Bt} 2$ e $\mathrm{Bt} 3)$ o feldspato é predominantemente microclínio, com a ocorrência de pseudomorfoses para caulinita, exceto no silte fino. 
Tabela 18. Mineralogia do perfil 8 ( PL ), em \% de peso da terra fina $<2 \mathrm{~mm}\left(\mathrm{~g} \mathrm{~kg}^{-1}\right)$.

\begin{tabular}{|c|c|c|c|c|c|c|c|c|}
\hline \multirow[b]{2}{*}{ Horiz. } & \multirow[b]{2}{*}{ Prof.(cm) } & \multirow[b]{2}{*}{ Tipo de Mineral } & \multicolumn{5}{|c|}{ Tamanho da fração $(\mu \mathrm{m})$} & \multirow[b]{2}{*}{$\Sigma$} \\
\hline & & & $>200$ & $200-53$ & $53-20$ & $20-2$ & $<2$ & \\
\hline \multirow{7}{*}{ A } & \multirow{7}{*}{$0-25$} & Quartzo & 190 & 370 & 21 & 34 & - & 615 \\
\hline & & Plagioclásio $^{1}$ & 51 & 32 & 15 & 34 & - & 132 \\
\hline & & Hornblenda & 14 & 41 & 5 & 5 & - & 65 \\
\hline & & Biotita $^{2}$ & - & - & 4 & - & - & 4 \\
\hline & & Caulinita & - & - & 3 & 12 & 55 & 70 \\
\hline & & Vermiculita & & & & 23 & 64 & 87 \\
\hline & & $\Sigma$ & 255 & 443 & 48 & 108 & 119 & $973^{3}$ \\
\hline \multirow{8}{*}{$2 \mathrm{Btn}$} & \multirow{8}{*}{$25-58$} & Quartzo & 130 & 210 & 9 & 36 & - & 385 \\
\hline & & Plagioclásio & 140 & 24 & 3 & 38 & - & 205 \\
\hline & & Hornblenda & 3 & 18 & 2 & 32 & - & 55 \\
\hline & & Biotita & - & 12 & 1 & - & - & 13 \\
\hline & & Caulinita & - & - & - & 6 & 140 & 146 \\
\hline & & Montmorilonita & - & - & - & - & 150 & 150 \\
\hline & & Vermiculita & - & - & - & 8 & - & 8 \\
\hline & & $\Sigma$ & 273 & 264 & 15 & 120 & 290 & 962 \\
\hline \multirow{8}{*}{$2 \mathrm{Cr}$} & \multirow{8}{*}{$58+$} & Quartzo & 130 & 200 & 4 & 9 & - & 343 \\
\hline & & Plagioclásio & 200 & 25 & 1 & 13 & - & 239 \\
\hline & & Hornblenda & 25 & 54 & 2 & 18 & - & 99 \\
\hline & & Biotita & 90 & 56 & 6 & - & - & 152 \\
\hline & & Caulinita & - & - & - & 3 & 7 & 10 \\
\hline & & Montmorilonita & - & - & - & - & 43 & 43 \\
\hline & & Vermiculita & - & - & - & 43 & 50 & 93 \\
\hline & & $\sum$ & 445 & 335 & 13 & 86 & 100 & 979 \\
\hline
\end{tabular}

1) Predomina albita, até andesita;

2) Flogopita-biotita nas frações areia e silte grosso;

3) A diferença para 1000 está associada a minerais pesados, partículas opacas e indeterminadas. 

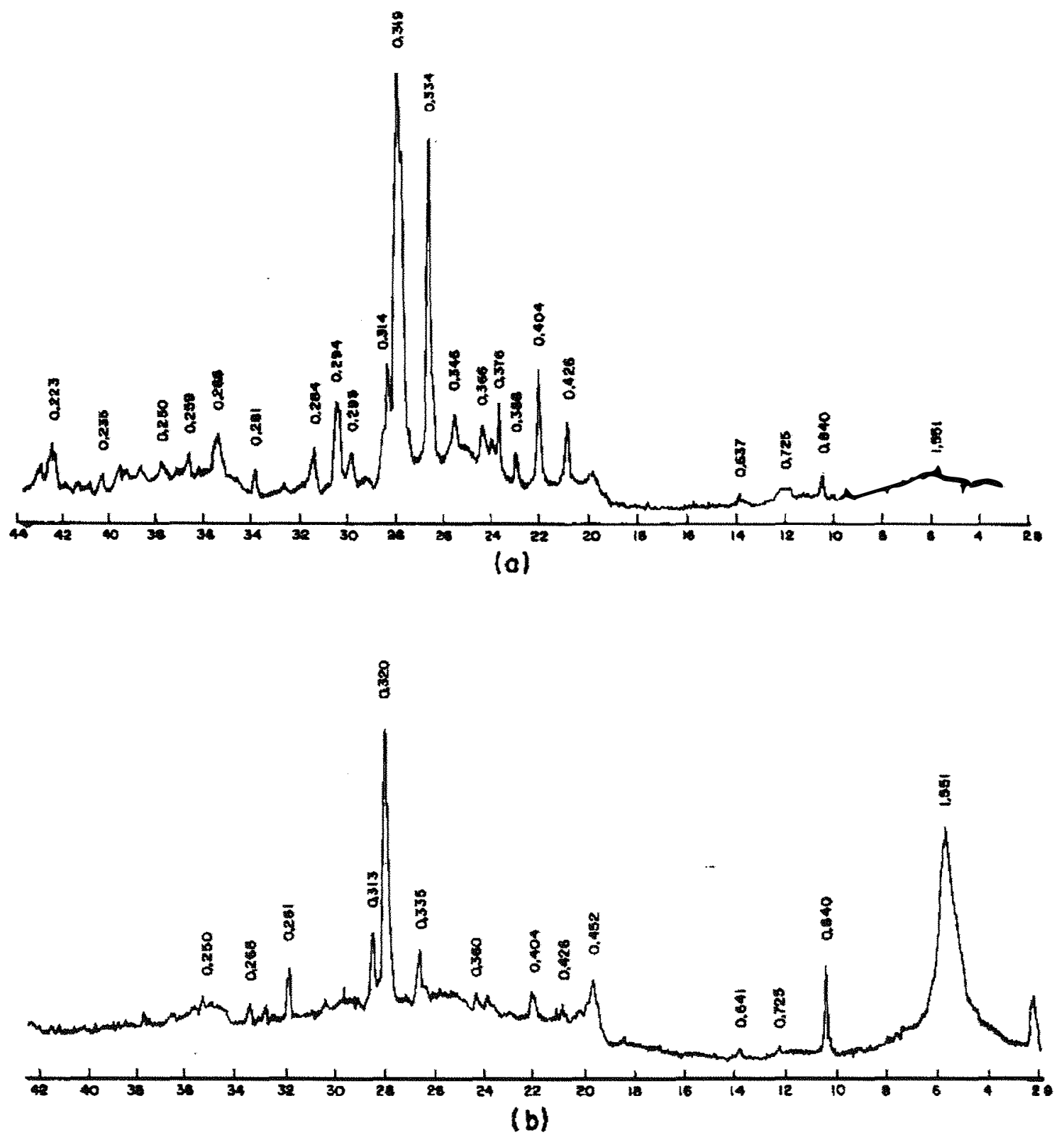

Figura 22 - Difratogramas da fração silte fino do perfil 8 (PL). (a) horizonte 2Btn e (b) horizonte $2 \mathrm{Cr}$ (tratamentos com $\mathrm{K}^{+}$a $25^{\circ} \mathrm{C}$ ). 
Tabela 19. Mineralogia do perfil 10 ( PVe ), em $\%$ de peso da terra fina $<2 \mathrm{~mm}$ ( $\mathrm{g} \mathrm{kg}^{-1}$ ).

\begin{tabular}{|c|c|c|c|c|c|c|c|c|}
\hline \multirow[b]{2}{*}{ Horiz. } & \multirow[b]{2}{*}{ Prof.(cm) } & \multirow{2}{*}{$\begin{array}{l}\text { Tipo de } \\
\text { Mineral }\end{array}$} & \multicolumn{5}{|c|}{ Tamanho da fração $(\mu \mathrm{m})$} & \multirow[b]{2}{*}{$\Sigma$} \\
\hline & & & $>200$ & $200-53$ & $53-20$ & $20-2$ & $<2$ & \\
\hline \multirow{7}{*}{ A } & \multirow{7}{*}{$0-30$} & Quartzo & 110 & 44 & 6 & 11 & 20 & 191 \\
\hline & & Feldspato & 264 & 154 & 18 & 70 & - & 506 \\
\hline & & Pseudo- $\mathrm{F}^{2}$ & 43 & 11 & 3 & - & - & 57 \\
\hline & & Biotita $^{3}$ & - & - & 1 & 11 & - & 12 \\
\hline & & Caulinita & - & - & - & 17 & 139 & 156 \\
\hline & & Vermiculita & - & - & - & - & 40 & 40 \\
\hline & & $\Sigma$ & 417 & 209 & 28 & 109 & 199 & $962^{\circ}$ \\
\hline \multirow{7}{*}{ Bt1 } & \multirow{7}{*}{$30-53$} & Quarzo & 32 & 31 & 4 & 16 & 33 & 116 \\
\hline & & Feldspato & 256 & 96 & 8 & 85 & - & 445 \\
\hline & & Pseudo & 15 & 16 & 3 & - & - & 34 \\
\hline & & Biotita & - & 8 & 4 & 26 & - & 38 \\
\hline & & Caulinita & - & - & - & 42 & 247 & 289 \\
\hline & & Vermiculita & - & - & - & - & 44 & 44 \\
\hline & & $\Sigma$ & 303 & 151 & 19 & 169 & 324 & 966 \\
\hline \multirow{8}{*}{ Bt2 } & \multirow{8}{*}{$53-79$} & Quartzo & 31 & 22 & 4 & 19 & 34 & 110 \\
\hline & & Feldspato ${ }^{1}$ & 243 & 83 & 8 & 95 & - & 429 \\
\hline & & Pseudo-F & 16 & 7 & 3 & - & - & 26 \\
\hline & & Biotita & - & 15 & 2 & 27 & - & 44 \\
\hline & & Pseudo- $\mathrm{M}^{4}$ & - & 7 & 2 & - & - & 9 \\
\hline & & Caulinita & - & - & - & 47 & 272 & 319 \\
\hline & & Vermiculita & - & - & - & - & 33 & 33 \\
\hline & & $\sum$ & 290 & 134 & 19 & 188 & 339 & 970 \\
\hline \multirow{8}{*}{$\mathrm{Bt} 3$} & \multirow{8}{*}{$79-113$} & Quarzzo & 63 & 23 & 3 & 18 & 32 & 139 \\
\hline & & Feldspato & 186 & 90 & 4 & 81 & - & 361 \\
\hline & & Pseudo-F & 31 & 8 & 2 & - & - & 41 \\
\hline & & Biotita & 9 & 15 & 4 & 28 & - & 56 \\
\hline & & Pseudo-M & - & 7 & 4 & - & - & 11 \\
\hline & & Caulinita & - & - & - & 71 & 227 & 298 \\
\hline & & Vermiculita & - & - & - & - & 48 & 48 \\
\hline & & $\Sigma$ & 289 & 143 & 17 & 198 & 307 & 954 \\
\hline \multirow{8}{*}{$\mathrm{BC}$} & \multirow{8}{*}{$113-140$} & Quartzo & 42 & 38 & 3 & 9 & 8 & 100 \\
\hline & & Feldspato $^{5}$ & 168 & 91 & 4 & 35 & - & 298 \\
\hline & & Pseudo-F & 41 & 42 & 3 & - & - & 86 \\
\hline & & Biotita & 82 & 98 & 12 & 17 & - & 209 \\
\hline & & Pseudo-M & 43 & 95 & 6 & - & & 144 \\
\hline & & Caulinita & - & - & - & 27 & 55 & 82 \\
\hline & & Vermiculita & - & - & - & - & 16 & 16 \\
\hline & & $\Sigma$ & 376 & 364 & 28 & 88 & 79 & 935 \\
\hline \multirow{8}{*}{$\mathrm{Cr}$} & \multirow{8}{*}{$140-190+$} & Quarzzo & 41 & 37 & 3 & 9 & 9 & 99 \\
\hline & & Feldspato ${ }^{5}$ & 210 & 107 & 5 & 36 & - & 358 \\
\hline & & Pseudo-F & 42 & 48 & 3 & - & - & 93 \\
\hline & & Biotita & 83 & 78 & 13 & 18 & - & 192 \\
\hline & & Pseudo-M & 40 & 67 & 5 & - & - & 112 \\
\hline & & Caulinita & - & - & - & 24 & 63 & 87 \\
\hline & & Vermiculita & - & - & - & - & 18 & 18 \\
\hline & & $\Sigma$ & 416 & 337 & 29 & 87 & 90 & 959 \\
\hline
\end{tabular}

1) Preponderamemente microclínio;

2) Pseudomorfose de feldspato para caulinita;

3) Preponderantemente flogopita-biotita;

4) Pseudomorfose de mica para caulinita

5) Preponderanternente albita;

6) A diferença para 1000 está associada a minerais pesados, particulas opacas e indeterninadas. 
Tabela 20. Mineralogia do perfil 11 ( SS ), em \% de peso da terra fina $<2 \mathrm{~mm}\left(\mathrm{~g} \mathrm{~kg}^{-1}\right.$ ).

\begin{tabular}{|c|c|c|c|c|c|c|c|c|}
\hline \multirow[b]{2}{*}{ Horiz. } & \multirow[b]{2}{*}{ Prof.(cm) } & \multirow{2}{*}{$\begin{array}{l}\text { Tipo de } \\
\text { Mineral }\end{array}$} & \multicolumn{4}{|c|}{ Tamanho da fração $(\mu \mathrm{m})$} & \multirow[b]{2}{*}{$<2$} & \multirow[b]{2}{*}{$\Sigma$} \\
\hline & & & $>200$ & $200-53$ & $53-20$ & $20-2$ & & \\
\hline \multirow{6}{*}{ A } & \multirow{6}{*}{$0-15$} & Quartzo & 98 & 353 & 109 & 40 & 4 & 604 \\
\hline & & Plagioclásio & 12 & 135 & 59 & 11 & 4 & 221 \\
\hline & & Biotita $^{2}$ & 5 & 13 & 11 & - & - & 29 \\
\hline & & Caulinita $^{3}$ & - & - & 4 & 6 & 56 & 66 \\
\hline & & Vermiculita & - & - & - & - & 16 & 16 \\
\hline & & $\Sigma$ & 115 & 501 & 183 & 57 & 80 & $936^{4}$ \\
\hline \multirow{6}{*}{$\mathrm{E}$} & \multirow{6}{*}{$15-32$} & Quartzo & 35 & 249 & 195 & 58 & 13 & 550 \\
\hline & & Plagioclásio & 11 & 114 & 58 & 40 & 14 & 237 \\
\hline & & Biotita & - & 10 & 5 & 6 & - & 21 \\
\hline & & Caulinita & - & - & 14 & 15 & 45 & 74 \\
\hline & & Vermiculita & - & - & - & - & 18 & 18 \\
\hline & & $\sum$ & 46 & 373 & 272 & 119 & 90 & 900 \\
\hline \multirow{6}{*}{$2 B \operatorname{tn}$} & \multirow{6}{*}{$32-62$} & Quartzo & 81 & 201 & 67 & 35 & 5 & 384 \\
\hline & & Plagioclásio & 7 & 20 & 32 & 22 & - & 81 \\
\hline & & Biotita & 1 & 3 & 9 & 25 & - & 38 \\
\hline & & Caulinita & - & 54 & 81 & 6 & 308 & 449 \\
\hline & & Vermiculita & - & - & - & - & - & - \\
\hline & & $\Sigma$ & 89 & 278 & 189 & 88 & 313 & 957 \\
\hline \multirow{6}{*}{$2 \mathrm{CB}$} & \multirow{6}{*}{$62-80+$} & Quartzo & 83 & 215 & 65 & 40 & 2 & 405 \\
\hline & & Plagioclásio & 16 & 127 & 40 & 25 & - & 208 \\
\hline & & Biotita & 17 & 114 & 86 & 28 & - & 245 \\
\hline & & Caulinita & - & 3 & 7 & 6 & 36 & 52 \\
\hline & & Vermiculita & - & - & - & - & 11 & 11 \\
\hline & & $\Sigma$ & 116 & 459 & 198 & 99 & 49 & 921 \\
\hline
\end{tabular}

1) Albita até andesita;

2) Flogopita-biotita;

3) Pseudomorfose de biotita para caulinita com forte incrustação de óxido de ferro, nas frações silte e areia fina;

4) A diferença para 1000 está associada a minerais pesados, partículas opacas e indeterminadas. 
Nos dois horizontes inferiores ( $\mathrm{BC}$ e $\mathrm{Cr}$ ) predomina albita, sendo também observadas nos mesmos, pseudomorfoses de biotita para caulinita em alguns tamanhos de frações.

No perfil 11 (SS - tabela 20), originado de gnaisse, os minerais básicos constituintes da areia e do silte são: quartzo, plagioclásios e biotita. Devido a origem pedimentar dos horizontes $\mathrm{A}$ e $\mathrm{E}$ os teores desses minerais são relativamente diferentes quando comparados com os horizontes $2 \mathrm{Bth} \mathrm{e}$ $2 \mathrm{CB}$ de natureza autóctone. No silte fino dos dois solos verifica-se a presença de caulinita (figuras 24 e 25). Os resultados aqui citados, concordam em sua quase totalidade com Batista (1988) e Moreira \& Gomes (1995).

B - Fração argila

No PVe (tabela 19 e figura 26), a mineralogia desta fração mostra uniformidade desde a superficie (horizonte A), até a parte mais profunda estudada do solo (horizonte $2 \mathrm{Cr}$ ), constituida por caulinita, vermiculita e quartzo. A caulinita apresenta um teor crescente do $2 \mathrm{Cr}$ em direção ao $2 \mathrm{Bt}$, voltando a diminuir no horizonte mais superficial. A vermiculita não tem nenhuma tendência regular de aumento ou declínio com a profundidade. $\mathrm{O}$ SS (tabela 20 e figura 27), apresenta diferenças marcantes qualitativa e semiquantitativamente entre os horizontes $\mathrm{A}$ e $\mathrm{E}$ e $2 \mathrm{Btn}$ e $2 \mathrm{CB}$. Esses últimos contêm essencialmente caulinita e quartzo, enquanto que os horizontes mais superiores apresentam ainda vermiculita e plagioclásios. Os resultados ora demonstrados, diferem em parte dos encontrados por Moreira (1979), Batista (1988) e Gomes \& Moreira (1995). Encontram concordância 

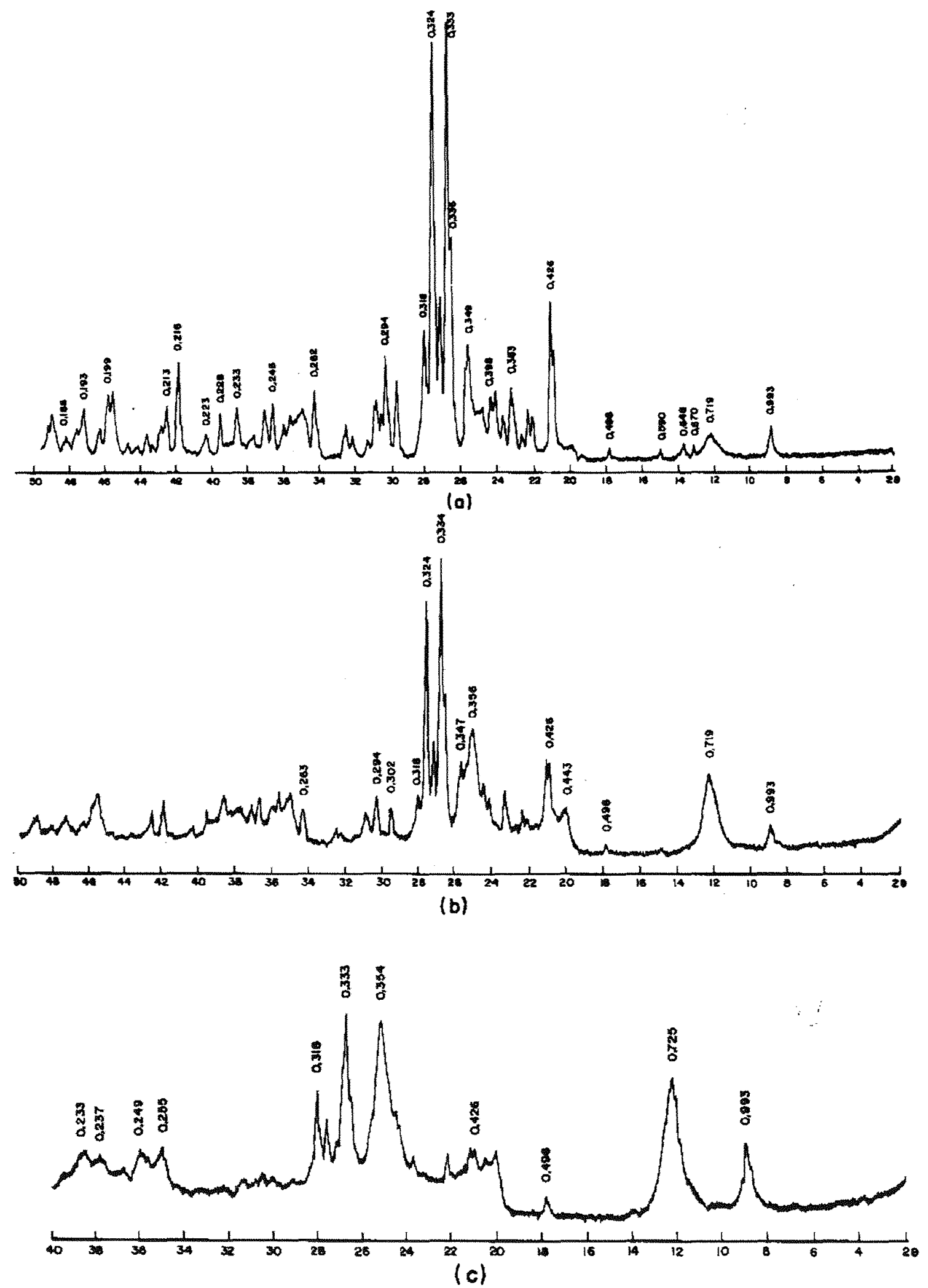

Figura 24 - Difratogramas da fração silte fino do perfil 10 (PVe). (a) horizonte $\mathrm{A}$; (b) horizonte Bt2 e (c) horizonte $\mathrm{Cr}$ (tratamentos com $\mathrm{K}^{+}$a $25^{\circ} \mathrm{C}$ ). 

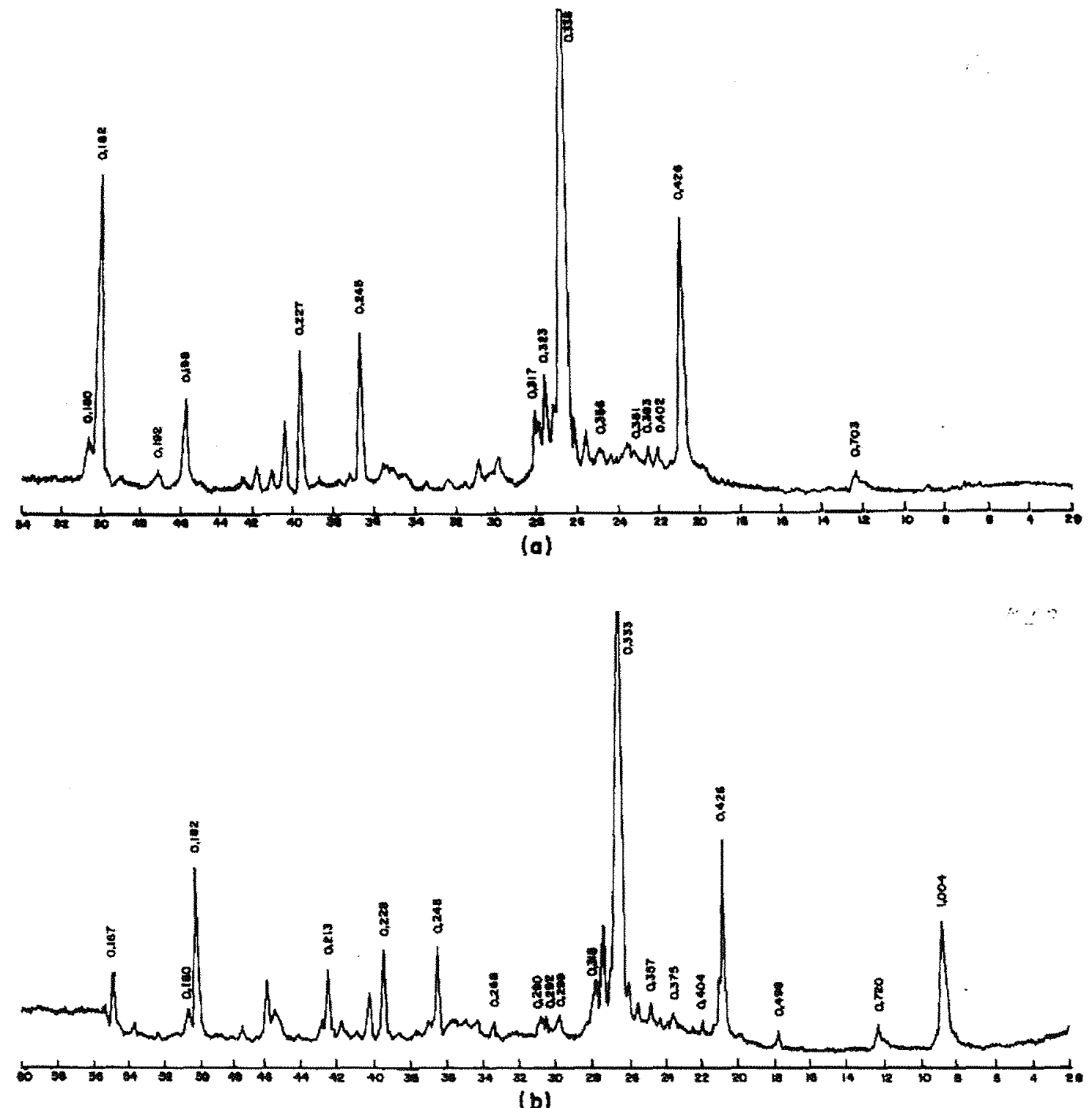

(b)

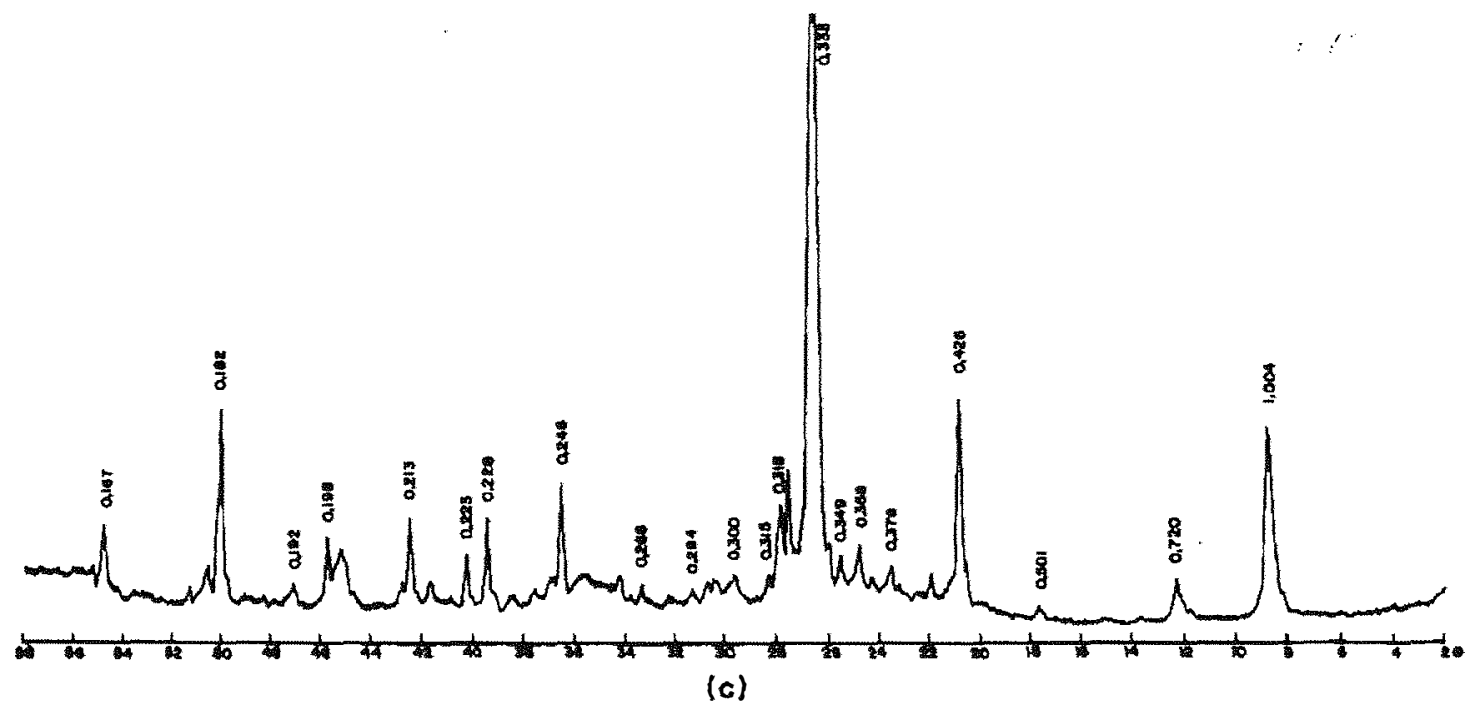

Figura 25 - Difratogramas da fração silte fino do perfil 11 (SS). (a) horizonte $\mathrm{A}$; (b) Horizonte $2 \mathrm{Btn}$; (c) horizonte $2 \mathrm{CB}$ (trat. com K $\mathrm{K}^{+} 25^{\circ} \mathrm{C}$ ). 


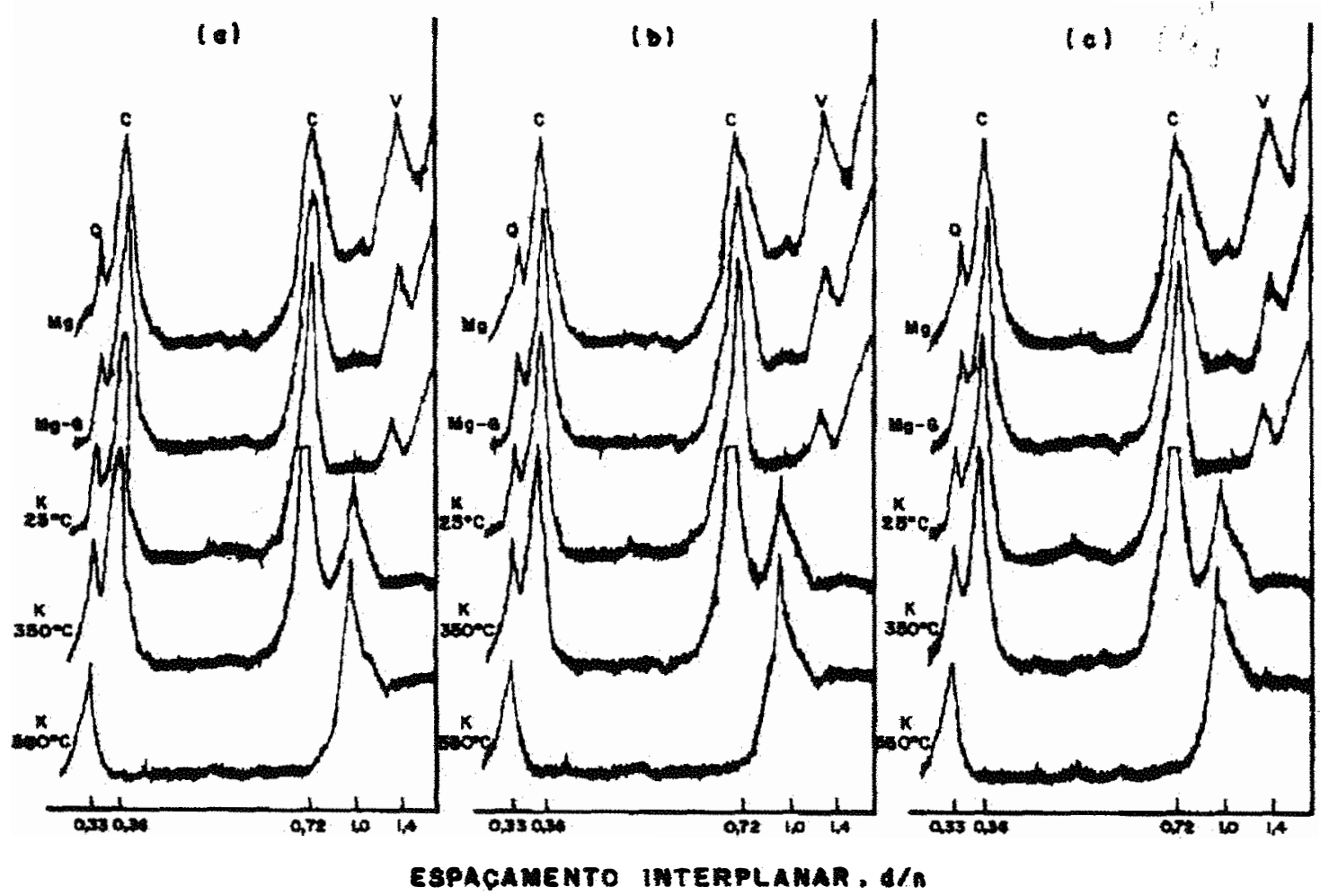

Figura 26 - Difratogramas da fração argila do perfil 10 (PVe). (a) horizonte A; (b) hori zonte $\mathrm{Bt} 2 \mathrm{e}$ (c) horizonte $\mathrm{Cr}$ (amostra orientada).

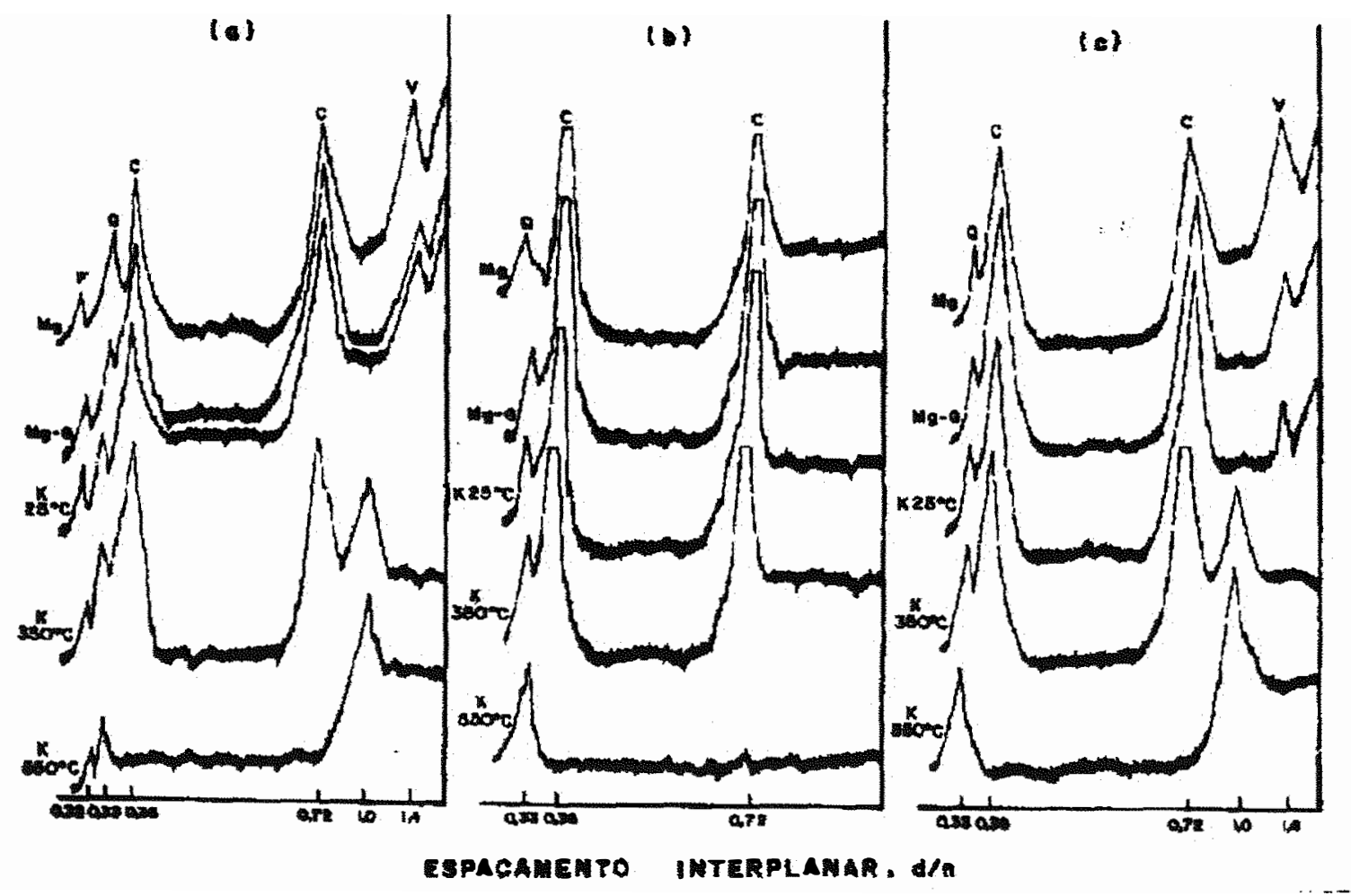

Figura 27 - Difratogramas da fração argila do perfil 11 (SS). (a) horizonte A; (b) hori zonte 2Btn e (c) horizonte 2CB (amostra orientada). 
porém, com Allen \& Fanning (1983). Como o SS aqui estudado, situa-se em uma região próxima ao litoral, diferente daqueles pesquisados pelos três primeiros autores citados acima, em zonas mais secas e com drenagem mais pobre, a natureza essencialmente caulinítica do perfil 11 pode ser justificada. Uma ação paleoclimática, nesse caso, também não está descartada, necessitando contudo, de estudos mais aprofundados para aceitar ou rejeitar essa hipótese.

\section{Transformações mineralógicas}

\section{Solos de Quixadá}

Ambos os solos estão submetidos às mesmas condições de clima, regime hídrico (ústico transicional para arídico) e vegetação regional (caatinga hiperxerófila), porém mostram grandes diferenças de drenagem interna. O PVe (perfil 1), que ocupa posições de topo e encosta é um solo de boa drenagem, enquanto que o PL (perfil 2), localizado na parte mais baixa da paisagem, tem drenagem imperfeita. A gênese dos argilo-minerais também é afetada pelas condições internas de drenagem do solo, assim nos dois perfis, já são encontrados no horizonte mais inferior a ocorrência conjunta de minerais do tipo 2:1 e 1:1 (caulinita, esmectita e/ou vermiculita). No perfil 2, verifica-se ainda a presença de um mineral interestratificado regular de vermiculita + mica. No perfil 1 , no horizonte acima mencionado, há dominância de vermiculita, enquanto que no perfil 2, predomina montmorilonita (tabelas 10 e 12). A influência das condições internas de 
drenagem do solo na gênese de minerais secundários, tem sido amplamente divulgada na literatura (Besoain, 1985; Cass \& Johnston, 1985; Demattê et al., 1991; Demattê \& Marconi, 1991; Luz et al., 1992).

As figuras 28 a 37 mostram aspectos das transformações mineralógicas que acontecem nos pedons dos solos de Quixadá. As figuras 28 e 29 apresentam proporções dos minerais mais intemperizáveis na fração areia (perfil 1) e areia + silte grosso (perfil 2), bem como a quantidade de argila formada (caulinita + vermiculita) no PVe e caulinita + esmectita + vermiculita + ilita + interestratificados no PL nas frações argila e silte fino, em função da profundidade. Verifica-se no PVe, que as quantidades de caulinita + vermiculita formadas nos horizontes de máxima acumulação de argila (2Bt2 e Bt1) correspondem aproximadamente com a diminuição das quantidades de minerais intemperizáveis dos horizontes $2 \mathrm{BC}$ até $\mathrm{Bt} 1$, implicando que a gênese desses argilo-minerais e consequentemente $o$ enriquecimento de argila do $\mathrm{B}$ textural ocorre essencialmente através da alteração desses minerais primários. A transformação da vermiculita para caulinita também parece evidente entre os horizontes $2 \mathrm{BC}$ ao $\mathrm{Bt} 1$. A presença de quartzo nas frações mais finas, decorre de herança da rocha matriz. 


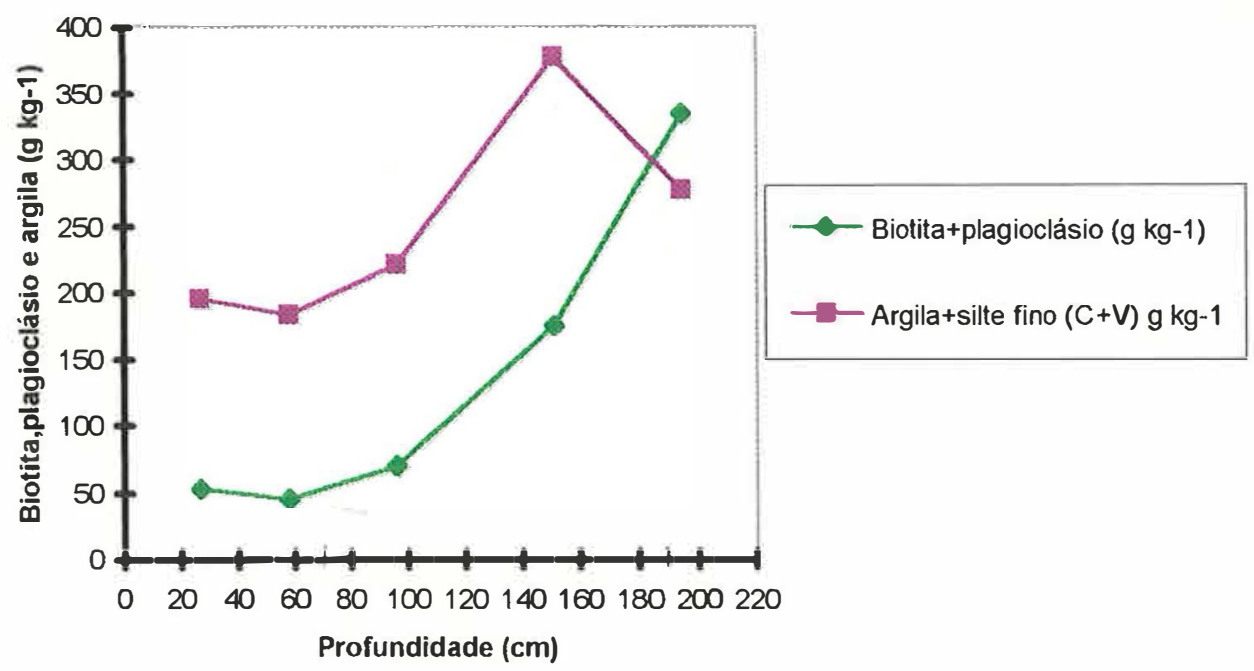

Figura 28 - Distribuição de minerais intemperizáveis da fração areia e caulinita + vermiculita nas fra ções silte fino e argila, com a profundidade, no perfil 1 (PVe).

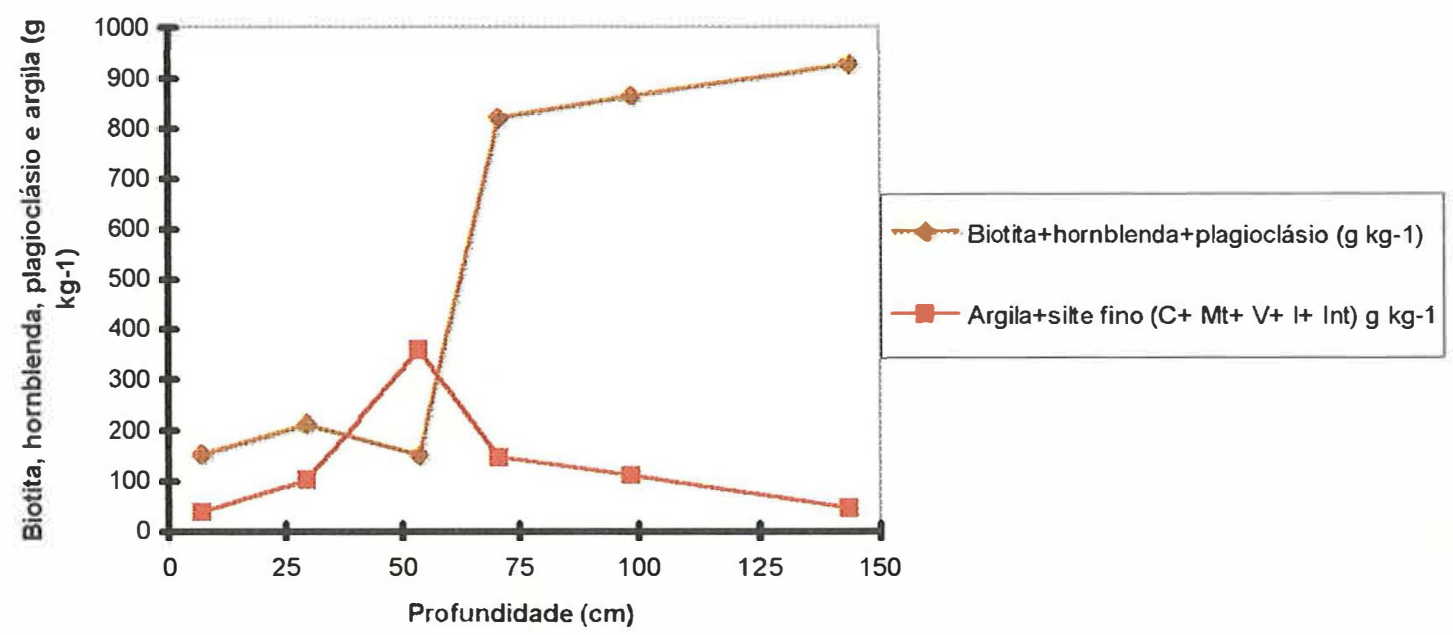

Figura 29 -Distribuição de minerais intemperizáveis da fração areia e caulinita + esmectita + vermiculita + ilita + interestratificado nas frações silte fino e argila, com a profundidade, no perfil 2 (PL). 
As prováveis sequências de intemperismo seriam: biotita $\Rightarrow$ vermiculita $\Rightarrow$ caulinita e plagioclásios $\Rightarrow$ caulinita. Aqui as condições de formação da vermiculita e não da montmorilonita são mais favoráveis devido às boas condições de drenagem do solo.

No PL (perfil 2), efetuando-se um balanço de decréscimo de minerais intemperizáveis do horizonte mais inferior $(2 \mathrm{Cr} 2)$, até o $2 \mathrm{Btn}$, com o aumento de argila que atinge um valor máximo nesse último horizonte, facilmente constata-se que o seu enriquecimento de argila e a gênese dos minerais secundários nele encontrados, resulta praticamente da alteração dos minerais primários intemperizáveis e/ou secundários “in situ”, presentes no material de origem do solo $(2 \mathrm{Cr} 2)$. A gênese de montmorilonita no perfil 2, está associada às condições de drenagem imperfeita do PL. A origem de montmorilonita a partir de mica ou hornblenda e sua preservação no solo em condições de drenagem impedida e região semi-árida, são amplamente relatadas na literatura especializada (Melfi et al., 1983; Singer, 1984; Cass \& Johnston, 1985; Rebertus et al., 1986; Garci et al., 1988)

As figuras 30 a 37 apresentam processos de alteração de minerais no perfil 2, obtidos por microscopia eletrônica de varredura. $\mathrm{O}$ uso dessa ferramenta no estudo de transformações e gênese de minerais de argila, tem sido utilizado com o propósito de fornecer informações complementares ou elucidar dúvidas que não podem ser facilmente obtidas com a microscopia ótica convencional e a difração de raios $\mathrm{X}$ (Eswaran, 1979; Berner \& Schott, 1982; Eswaran \& Shoba, 1983; Keller \& Balasubramaniam, 1989; Miklos et al., 1996). 


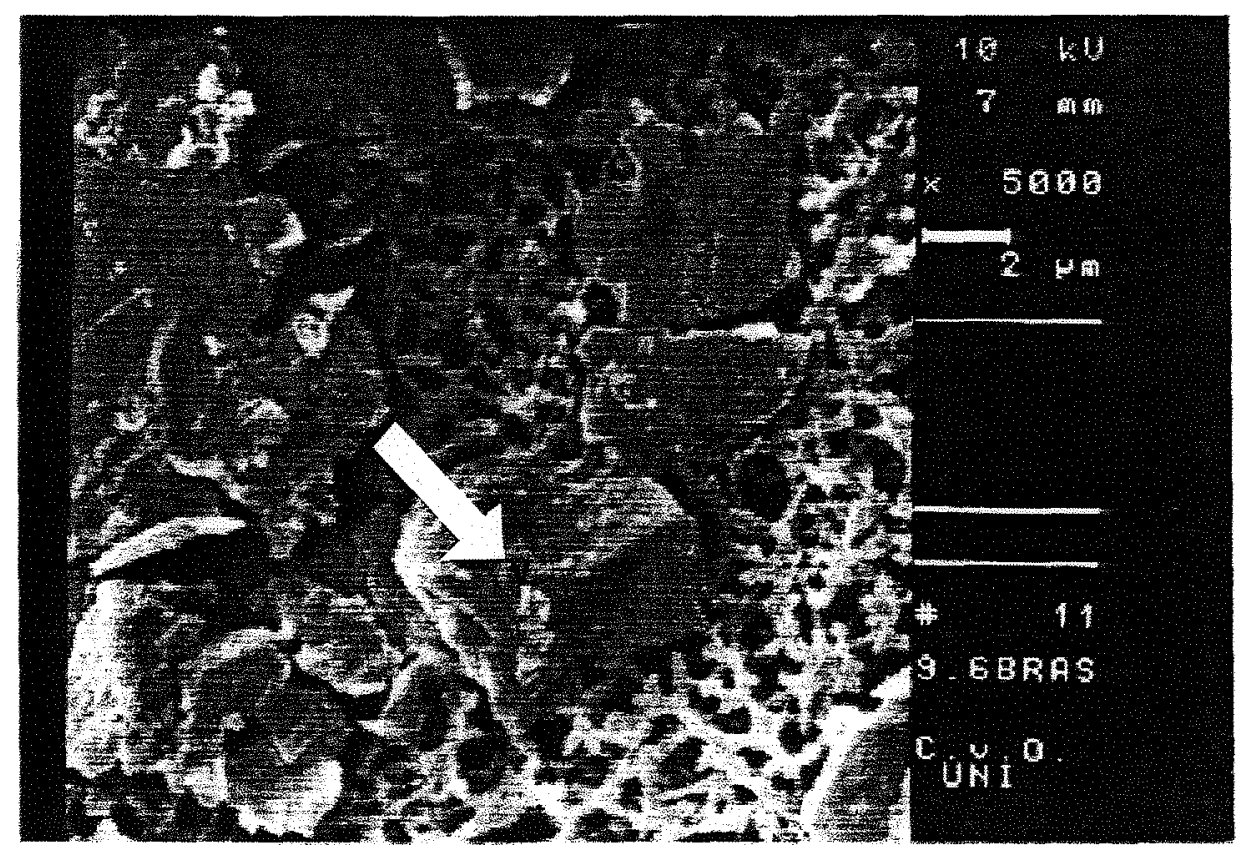

Figura 30

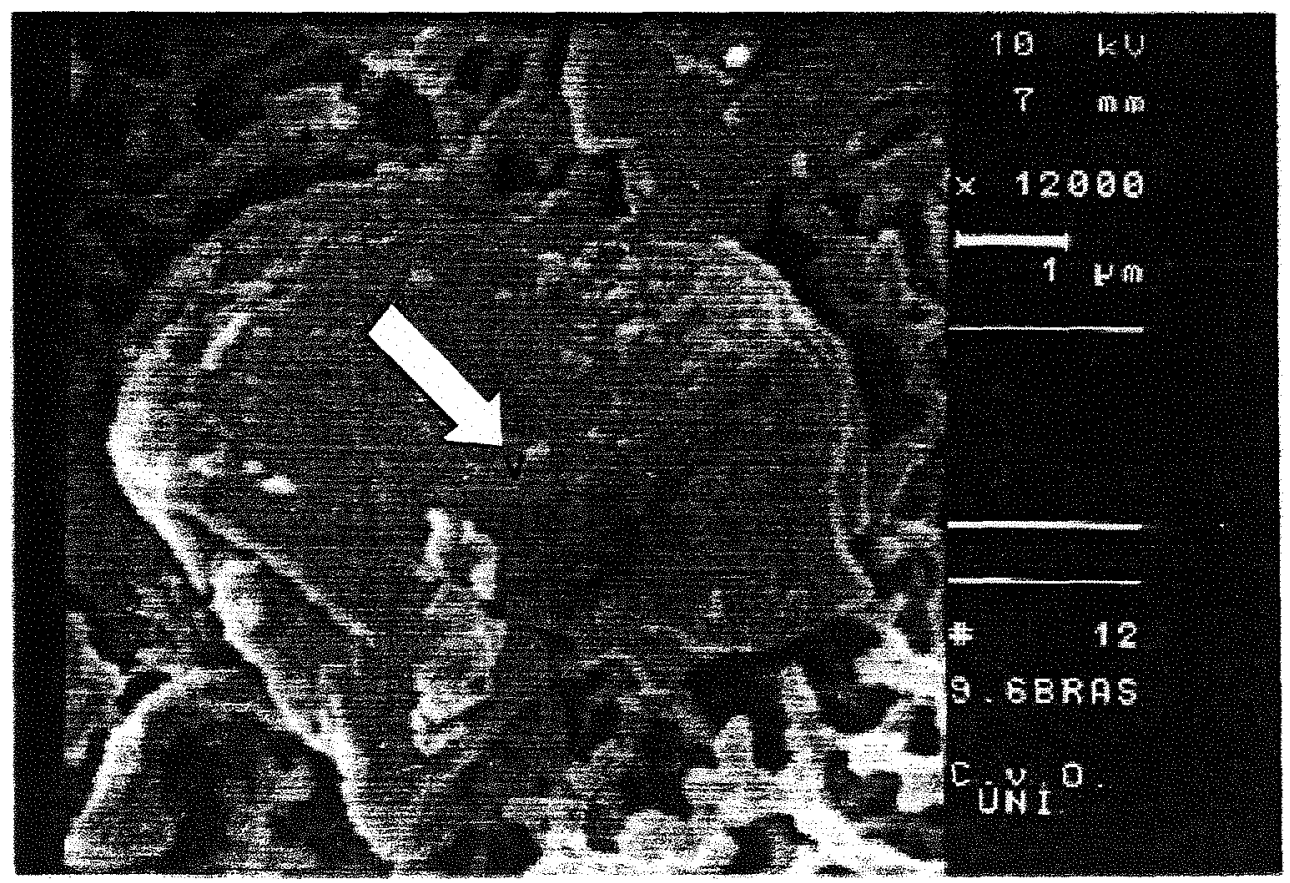

Figuras 30 e 31 - Fotografias obtidas por microscopia eletrônica de varredura, mostrando vermiculita $(\mathrm{V})$ intemperizada da biotita, na fração silte fino no horizonte $2 \mathrm{Cr} 1$ do perfil 2 (PL). 


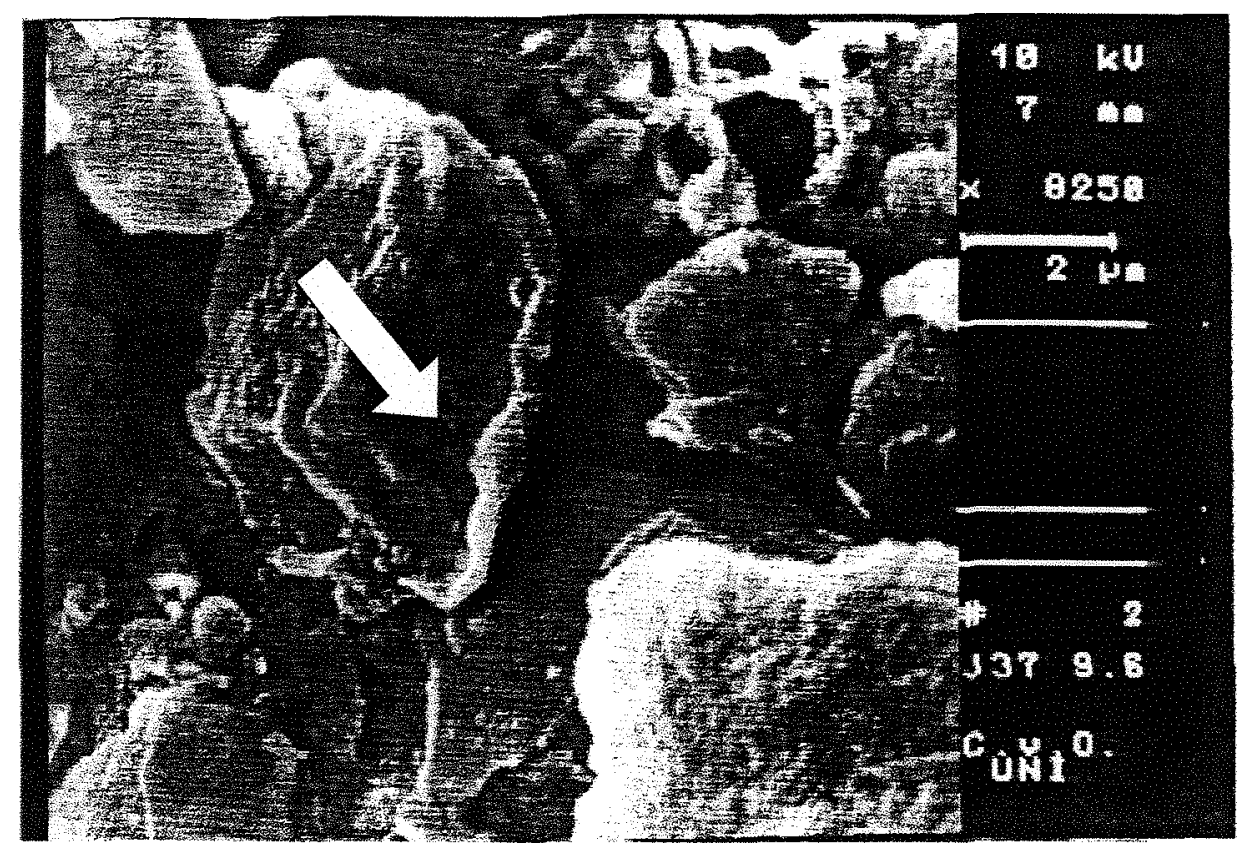

Figura 32

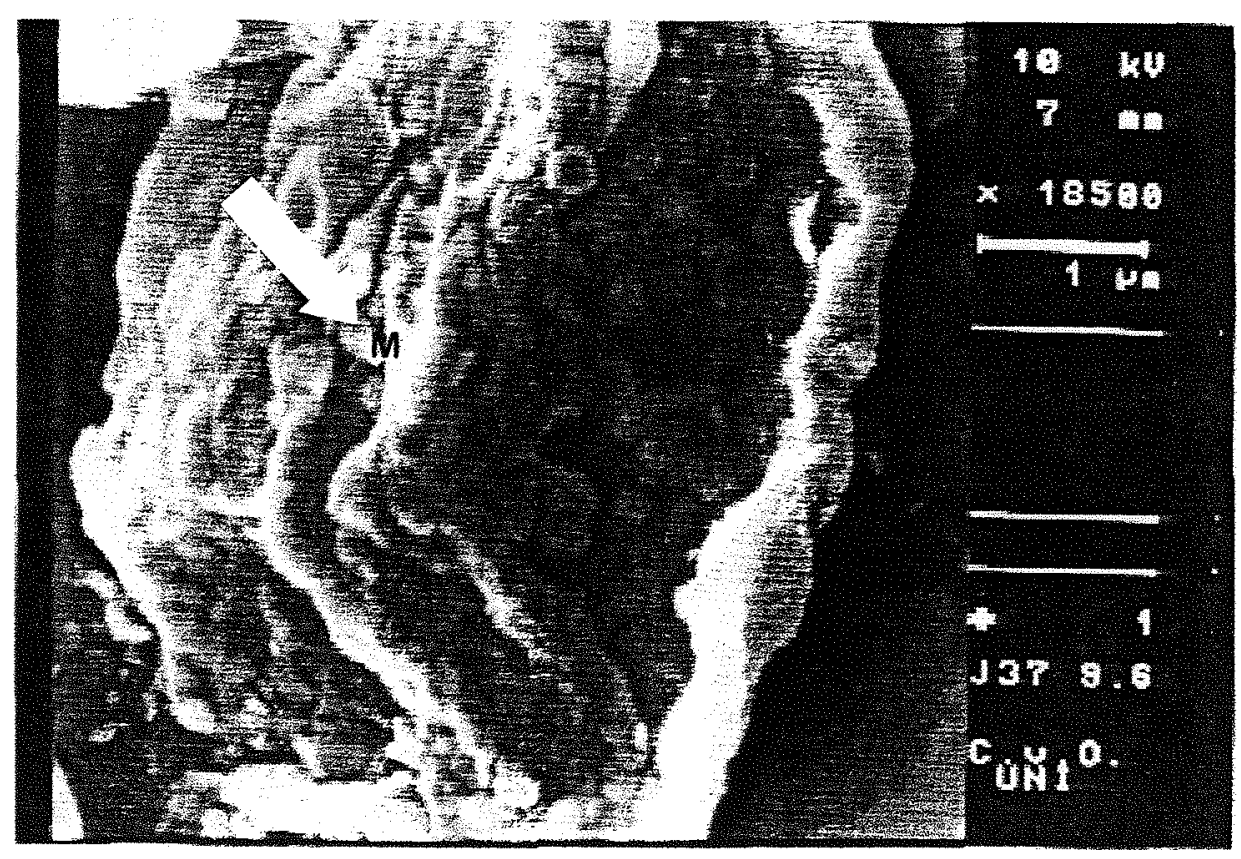

Figuras 32 e 33 - Fotografias obtidas por microscopia eletrônica de varredura, mostrando minerais de montmorilonita $(\mathrm{M})$, no horizonte $2 \mathrm{Cr} 2$ do perfil 2 (PL). 


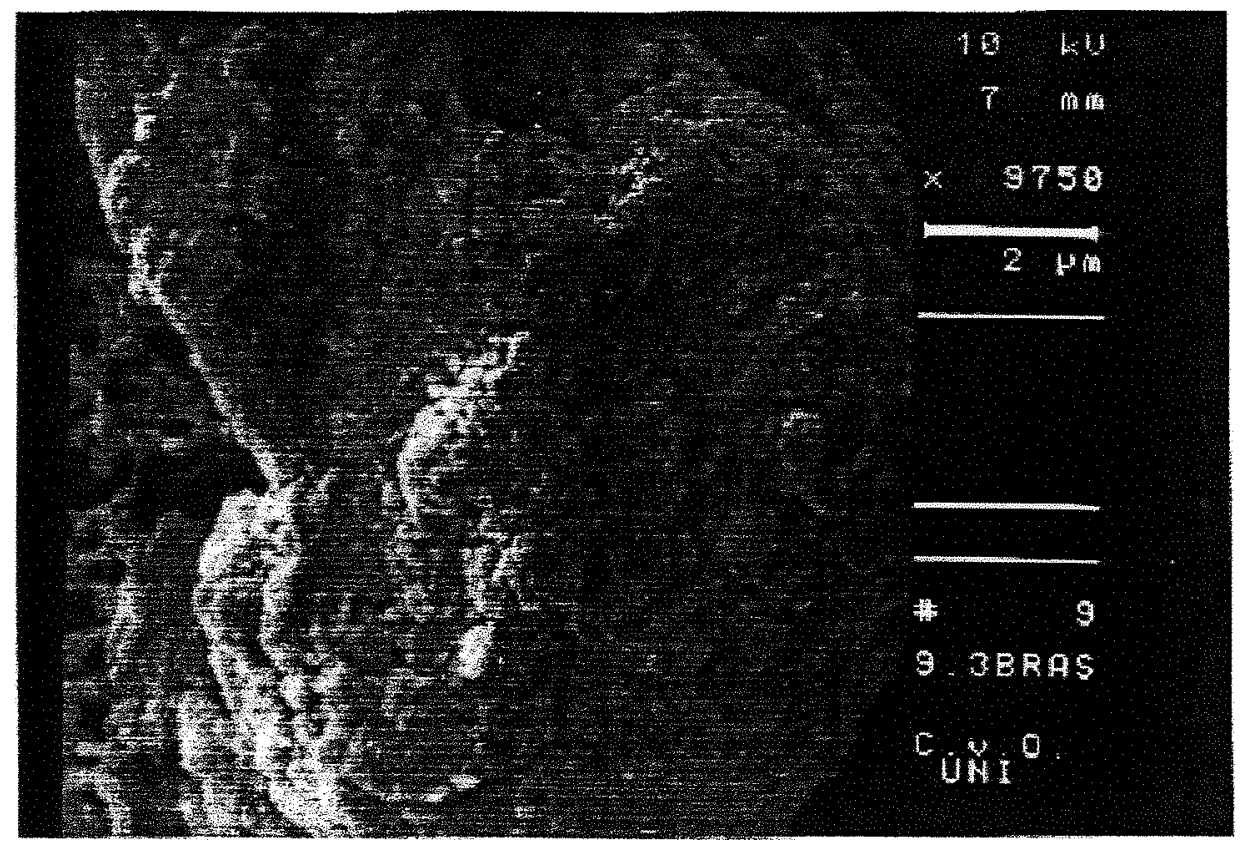

Figura 34

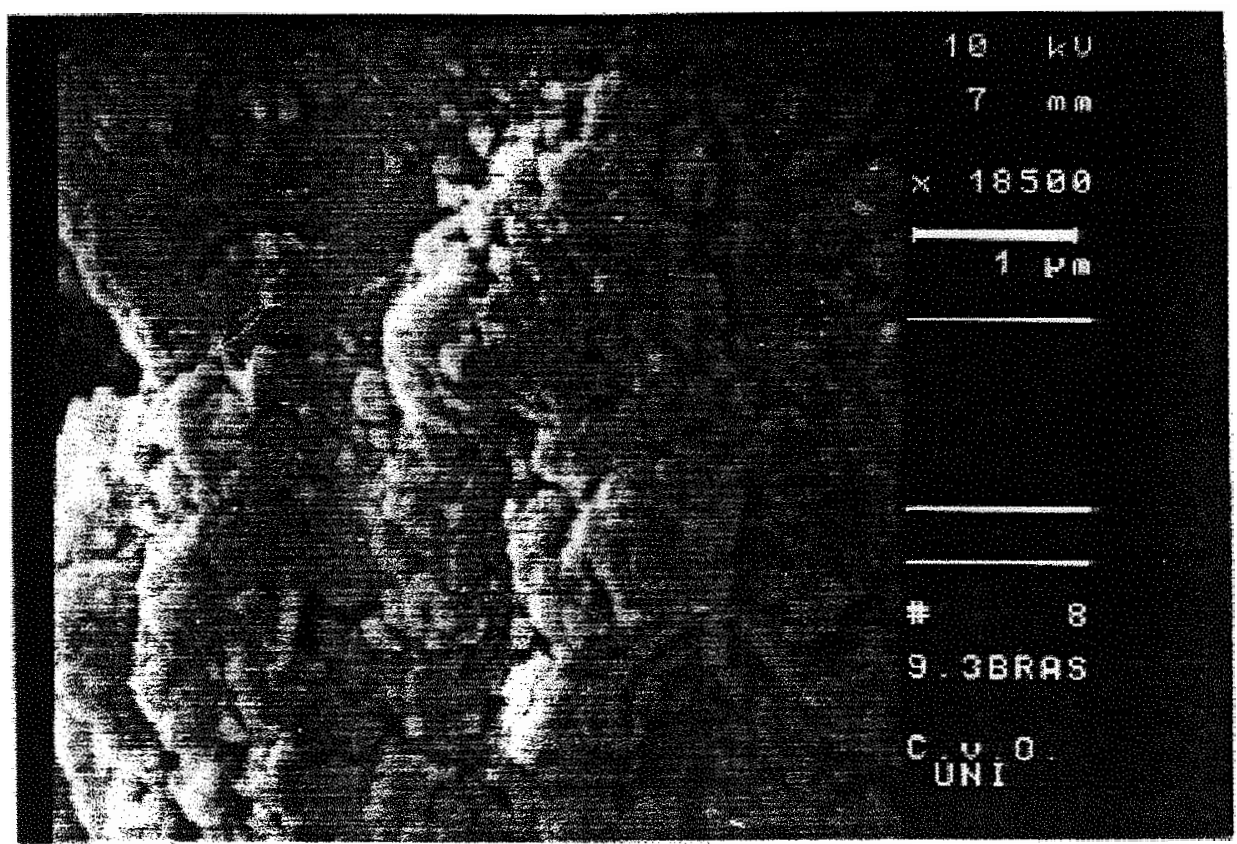

Figuras 34 e 35 - Fotografias obtidas por microscopia eletrônica de varredura, mostrando pseudomorfoses de vermiculita para caulinita, no horizonte $2 \mathrm{Btn}$ do perfil $2(\mathrm{PL})$. 


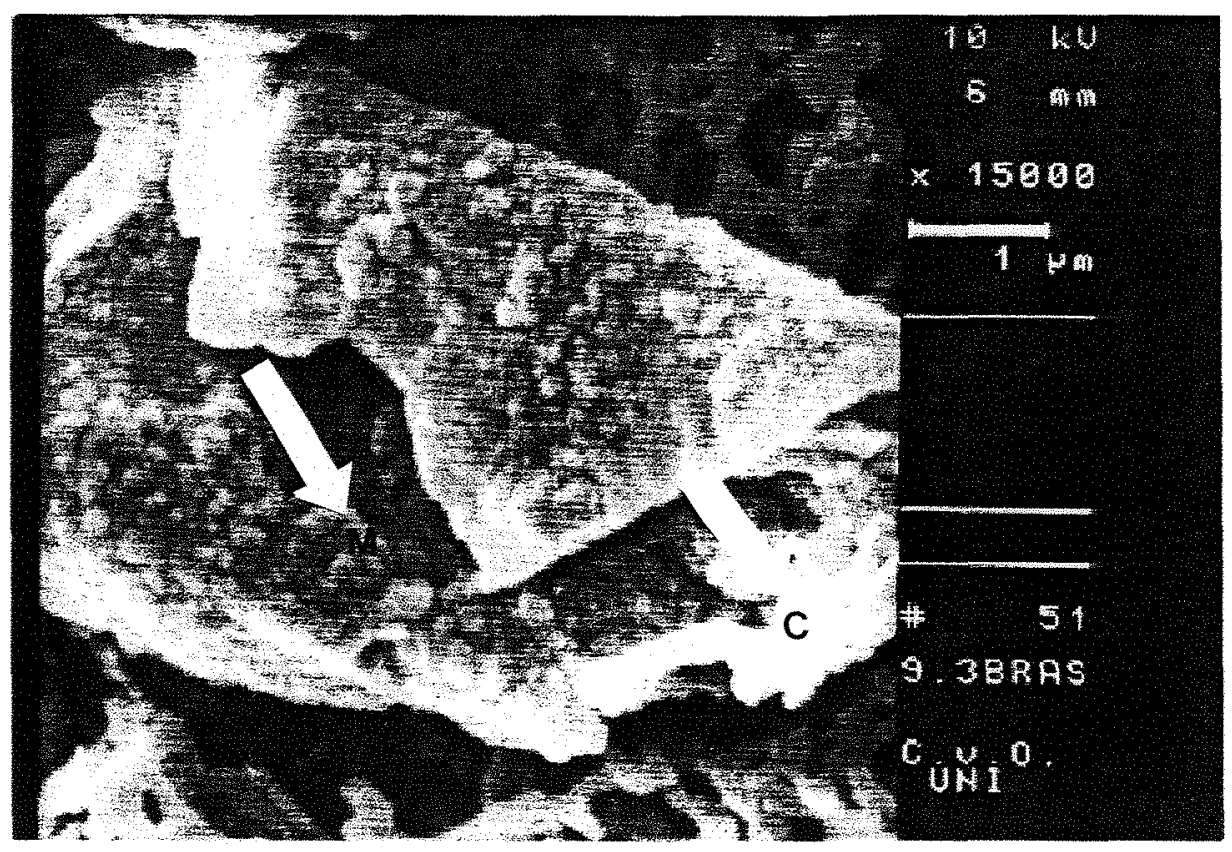

Figura 36

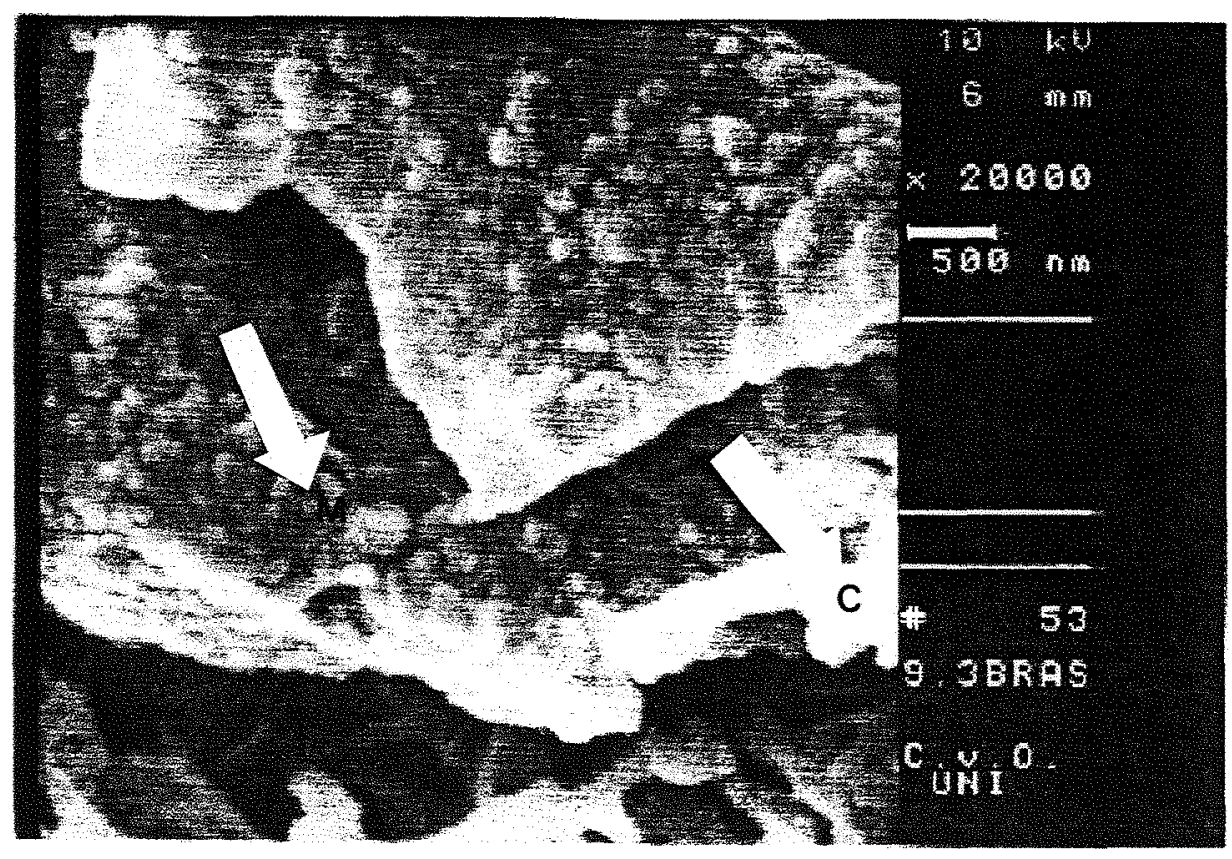

Figuras 36 e 37 - Fotografias obtidas por microscopia eletrônica de varredura, mostrando pseudomorfoses de montmorilonita $(\mathrm{M})$, para cau linita (C), no horizonte $2 \mathrm{Btn}$ do perfil 2 (PL). 
As figuras 30 e 31 mostram fotomicrografias da fração silte fino no horizonte $2 \mathrm{Cr} 1$ do $\mathrm{PL}$. Na primeira figura observa-se claramente vermiculita intemperizada da biotita. Pelo forte aumento, a estrutura em camadas formada no novo mineral, torna-se fácil de ser reconhecida. As figuras $32 \mathrm{e}$ 33 , por sua vez, exibem minerais de montmorilonita no horizonte $2 \mathrm{Cr} 2$ do mesmo perfil. Essas fotomicrografias apresentam o desfolhamento ou laminação e a forte dilatação do mineral, por causa das camadas interiores. Em parte já começa a se observar, nas margens, um enrolamento em escamas e o surgimento de plaquetas do tamanho da argila fina $(<0,2 \mu \mathrm{m})$. Estas consistem, porém, ainda de montmorilonita. Nas frações areia e silte grosso do horizonte $2 \mathrm{Btn}$, em princípio, verifica-se ainda, pseudomorfoses de biotita para vermiculita e de montmorilonita para caulinita. As figuras 34 e 35 mostram essas pseudomorfoses de vermiculita alterada da biotita para caulinita, no horizonte $2 \mathrm{Btn}$ do perfil 2. Esses agregados de cristais de caulinita, no tamanho da argila, representam assim, uma boa contribuição para a formação da argila "in situ". As figuras 36 e 37, apresentam pseudomorfoses de montmorilonita para caulinita também no horizonte $2 \mathrm{Btn}$, as quais contêm, igualmente, cristais de caulinita no tamanho da argila fina. Veja forte ampliação na parte inferior da fotografia. 


\section{Solos de Canindé}

As figuras 38, 39 e 40 mostram a distribuição de minerais intemperizáveis e a formação de argilo-minerais nas frações silte fino e argila em função da profundidade nos perfis $3(\mathrm{NC}), 4(\mathrm{NCL})$ e $5(\mathrm{NCv})$.

$\mathrm{O}$ material originário do NC é um biotita-gnaisse com 330 e $260 \mathrm{~g} \mathrm{~kg}^{-1}$ de flogopita-biotita trioctaédrica na fração areia grossa (tabela 13), nos horizontes $\mathrm{R}$ e $\mathrm{C}$ respectivamente. Através dos resultados verifica-se que essas quantidades se reduzem para $18 \mathrm{~g} \mathrm{~kg}^{-1}$ no horizonte $\mathrm{Bt}$, ao mesmo tempo que se formam nas frações silte fino e argila desse mesmo horizonte $170 \mathrm{~g} \mathrm{~kg}^{-1}$ de caulinita, $30 \mathrm{~g} \mathrm{~kg}^{-1}$ de montmorilonita e $40 \mathrm{~g} \mathrm{~kg}^{-1}$ de ilita. Assim a formação de argila no Bt é essencialmente devido à transformação da biotita nesses argilo-minerais, sendo a caulinita consideravelmente o produto final estável da decomposição. O material de origem do NCL também é um biotita-gnaisse com $310 \mathrm{~g} \mathrm{~kg}^{-1}$ de biotita $(190+120)$ nas frações areia grossa e fina do horizonte $\mathrm{Cr}$ (tabela 14). Nas frações areia do Bt as quantidades de biotita baixam para $125 \mathrm{~g} \mathrm{~kg}^{-1}(49+76)$, o que corresponde a uma redução em confronto com o horizonte $\mathrm{Cr}$ de $185 \mathrm{~g} \mathrm{~kg}^{-1}$. A essa redução do teor de biotita na areia se contrapõe um aumento da quantidade de caulinita + montmorilonita no silte fino e argila aproximadamente na mesma proporção (189 $\mathrm{g} \mathrm{kg}^{-1}$ ). Desse modo o enriquecimento de argila no $\mathrm{Bt}$ é explicado também no NCL, praticamente somente devido a processos de formação de argila in "situ", isto é, à decomposição (formação de montmorilonita) e à caulinitização da biotita e não, à translocação do horizonte A pobre nessa fração. Para isso apontam também as numerosas pseudomorfoses de biotita 
para caulinita existentes, especialmente no silte grosso. No perfil 5 (NCv), a rocha matriz trata-se de um hornblenda-gnaisse com $430 \mathrm{~g} \mathrm{~kg}^{-1}$ de hornblenda na fração areia grossa do horizonte Cr. Essa quantidade se reduz no horizonte Bt para $92 \mathrm{~g} \mathrm{~kg}^{-1}$, isto é, em cerca de $338 \mathrm{~g} \mathrm{~kg}^{-1}$. Em torno da mesma quantidade (369 $\mathrm{g} \mathrm{kg}^{-1}$ ), aumentam os teores de caulinita + montmorilonita das frações silte fino e argila. $\mathrm{O}$ enriquecimento da argila e do silte fino no $\mathrm{Bt}$ (369 $\mathrm{g} \mathrm{kg}^{-1}$ ), pode-se explicar perfeitamente se levarmos em conta ainda, a diminuição das pseudomorfoses da hornblenda na areia fina de $136 \mathrm{~g} \mathrm{~kg}^{-1}$ no horizonte $\mathrm{Cr}$ para $50 \mathrm{~g} \mathrm{~kg}^{-1}$ no Bt. A alteração da homblenda em comparação com a da biotita (NC e NCL), conduz a uma formação mais intensa de montmorilonita o que pode ser explicado pela drenagem interna e propriedades vérticas do solo.

Nos horizontes $\mathrm{Cr}$ e $\mathrm{R}$ dos perfis 3 e 4 aparecem preponderantemente flogopitas-biotitas ricas em ferro com mais de $70 \%$ de $\mathrm{Mg}$ (flogopitas) e aproximadamente de 20 a $60 \%$ de $\mathrm{Mg}$ (biotitas) nos octaedros. No solo, ou seja no Bt, a transformação da biotita é determinada essencialmente pelo regime hídrico do solo (condições de drenagem interna). As figuras 41 a 44 mostram processos de alteração da biotita nesses dois perfis. A figura 41 apresenta um forte intemperismo pedogenético da biotita permitindo reconhecer através de microscopia ótica de contraste de fase, o aparecimento do marron escuro do óxido de ferro separado. Esse fato não é possível de ser conseguido e reconhecido por microscopia eletrônica de varredura. A grande parte dos minerais aparecem, todavia, em razão de mudanças no valor da refração da luz. Dessa maneira, as manchas azul-acinzentadas-escuras que aparecem na foto, indicam que as transformações da biotita estão por 
acontecer. $\mathrm{O}$ índice de refração de tais manchas surgidas em determinadas zonas combinam com o aparecimento da caulinita permitindo deduzir-se que uma caulinitização pode ocorrer sem se ter uma exata certeza a respeito do efeito em profundidade do processo que poderá acontecer, se marginal ou contínuo. A figura 42 mostra um semelhante e forte intemperismo da biotita, por meio de uma fotomicrografia obtida por microscopia eletrônica de varredura. Aqui já é percebido um nítido, ascendente e total mineral caulinitizado, ou seja uma pseudomorfose de biotita para caulinita formada por um agregado de partículas de caulinita. As figuras 43, 44 e 45 apresentam fotografias do intemperismo da biotita em solos de boa drenagem (NC e NCL), obtidas por microscopia ótica de contraste de fase. A partir de biotitas frescas (figura 45), com separação inicial dos óxidos de ferro ocorre uma forte incrustação desses óxidos na parte central das lamínulas de biotita com dissolução simultânea da estrutura de base e caulinitização no âmbito marginal (figura 43). Por último tornam-se perceptíveis agregados cinzaescuros presentes na superficie que em estágios mais avançados impregnam toda a lamínula de biotita (figura 44) e finalmente desintegram-se em partículas de silte fino e/ou argila. As partículas representadas nas figuras 43 e 44 podem ser consideradas pseudo-formações de biotita em caulinita (Gebhardt et al. 1967, em função de microscopia de contraste de fase).

As figuras 46 a 50 mostram alguns aspectos de transformação da hormblenda no perfil $5(\mathrm{NCv})$ que tem drenagem deficiente. Semelhantemente à biotita, dependendo da drenagem do solo, a alteração da hornblenda pode evoluir para uma forte caulinitização ou formação de montmorilonita. A figura 46 apresenta hornblendas inalteradas que no $\mathrm{NCv}$ 


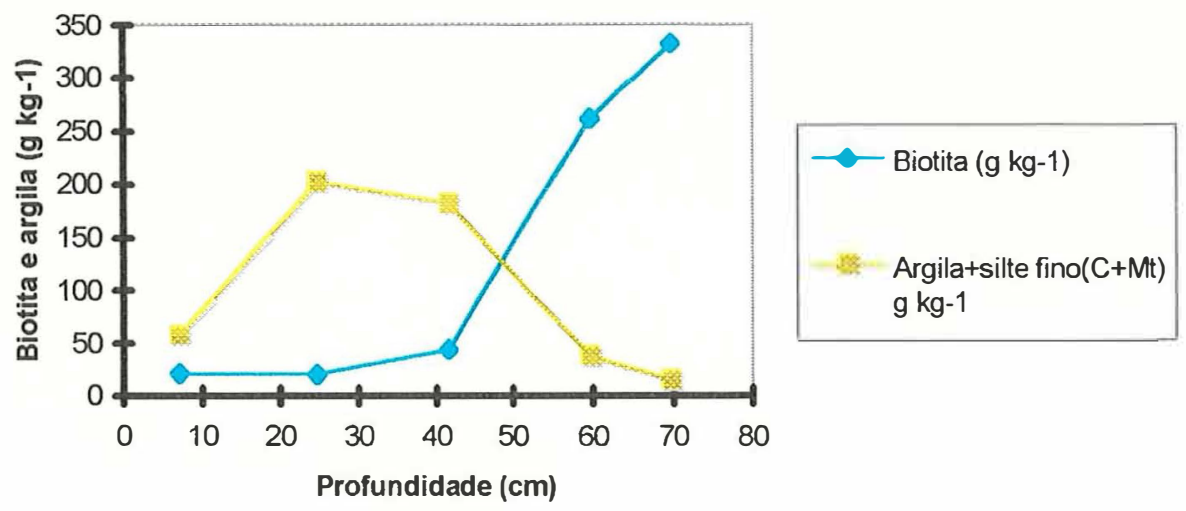

Figura 38 - Distribuição de minerais intemperizáveis da fração areia e caulinita + montmorilonita nas frações silte fino e argila, com a profundidade, no perfil 3 .

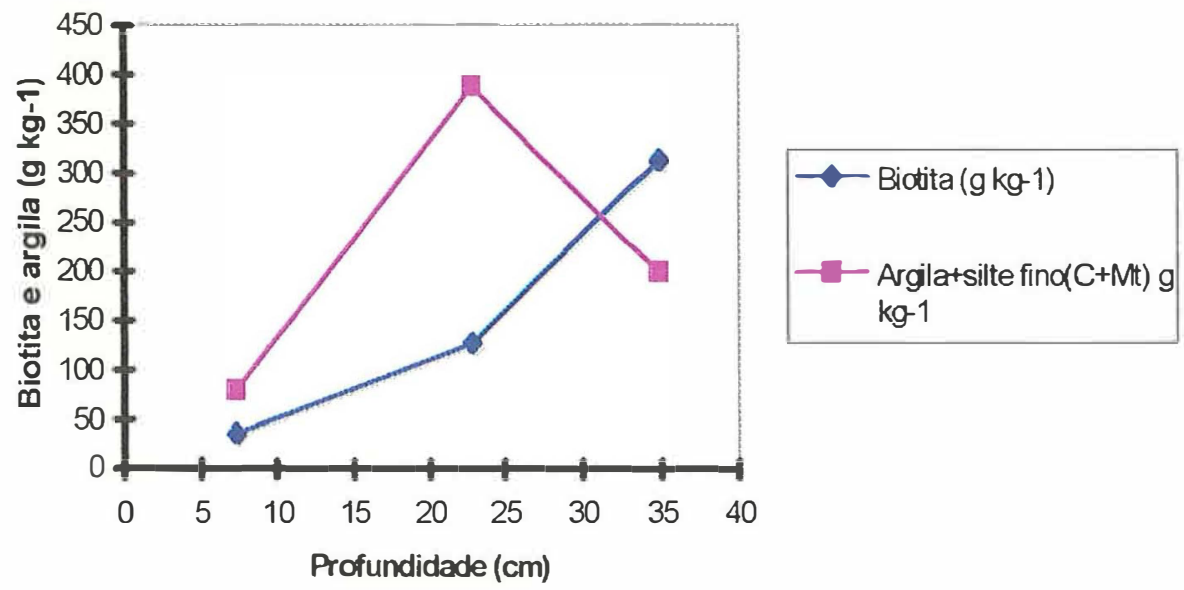

Figura 39 - Distribuição de minerais intemperizáveis da fração areia e caulinita + montmorilonita nas frações silte fino e argila, com a profundidade, no perfil 4 .

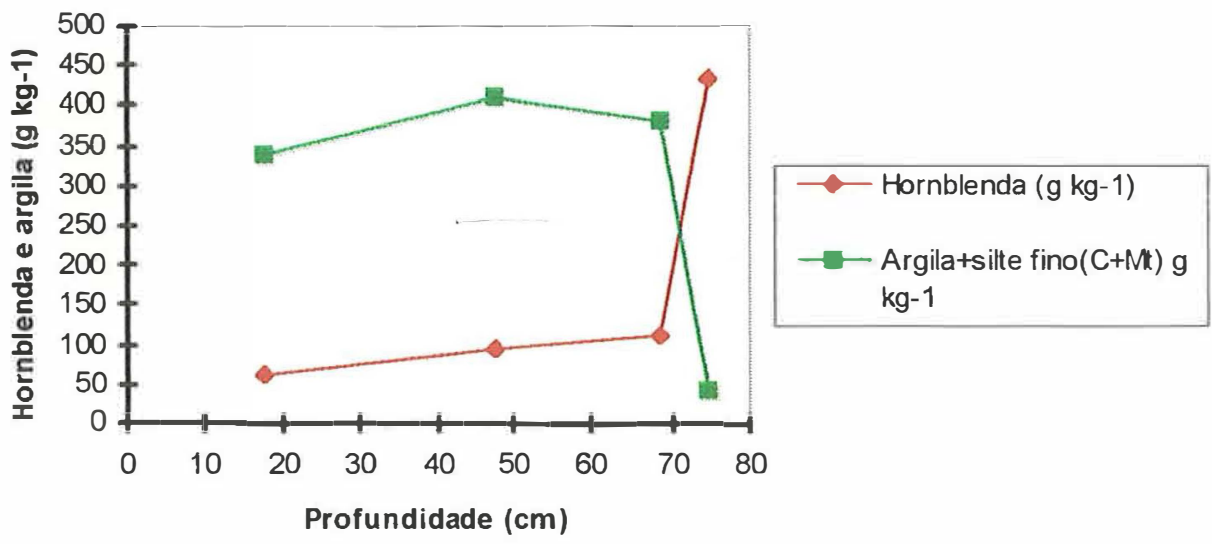

Figura 40 - Distribuição de minerais intemperizáveis da fração areia e caulinita + montmorilonita nas frações silte fino e argila, com a profundidade, no perfil 5 . 


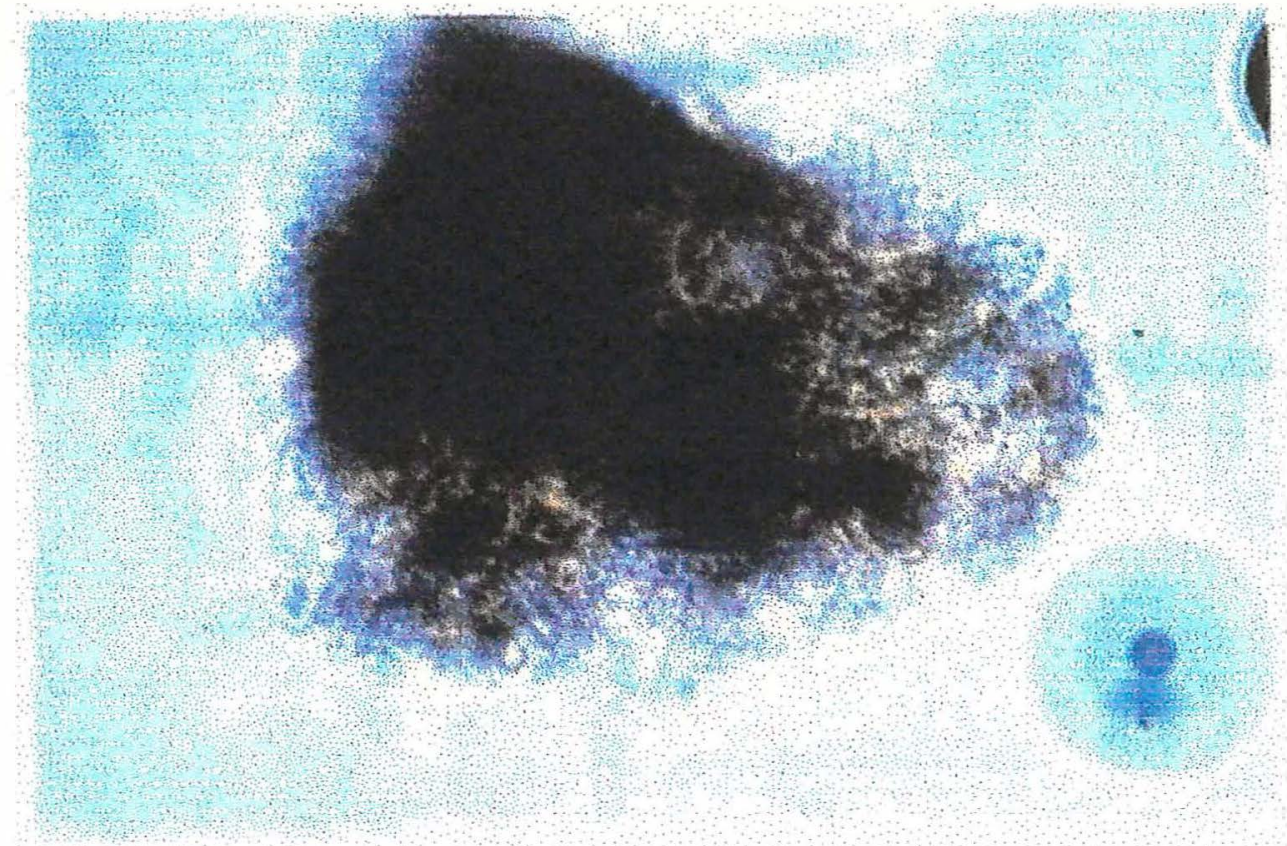

Figura 41 - Fotografia obtida por microscopia ótica de contraste de fase, mos trando um forte intemperismo pedoquímico da biotita na fração areia fina, no horizonte $\mathrm{Cr}$ do perfil 4 (NCL).

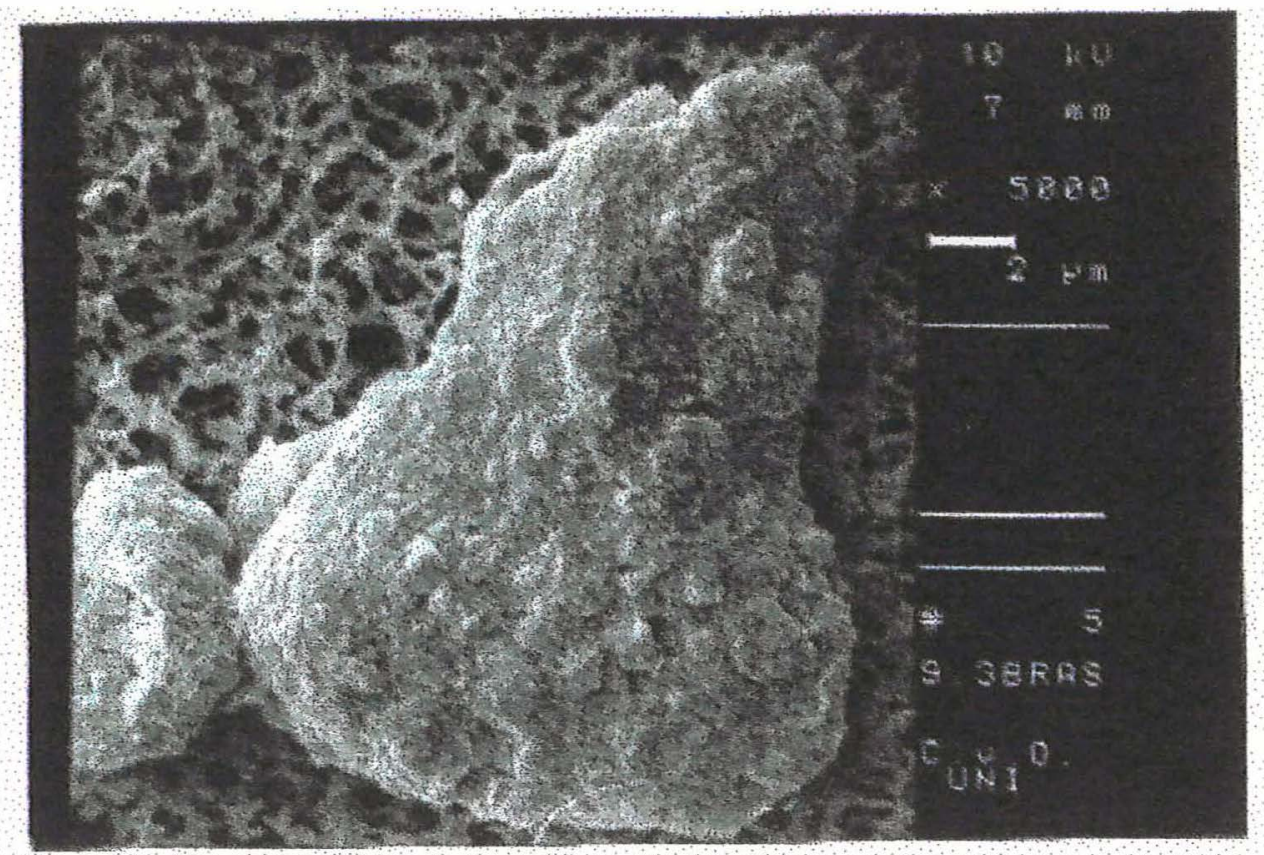

Figura 42 - Fotografia obtida por microscopia eletrônica de varredura, mos trando um forte intemperismo da biotita ( pseudomorfose de bio tita para caulinita ), na fração silte fino, no horizonte $\mathrm{Cr}$ do perfil 4 (NCL). 


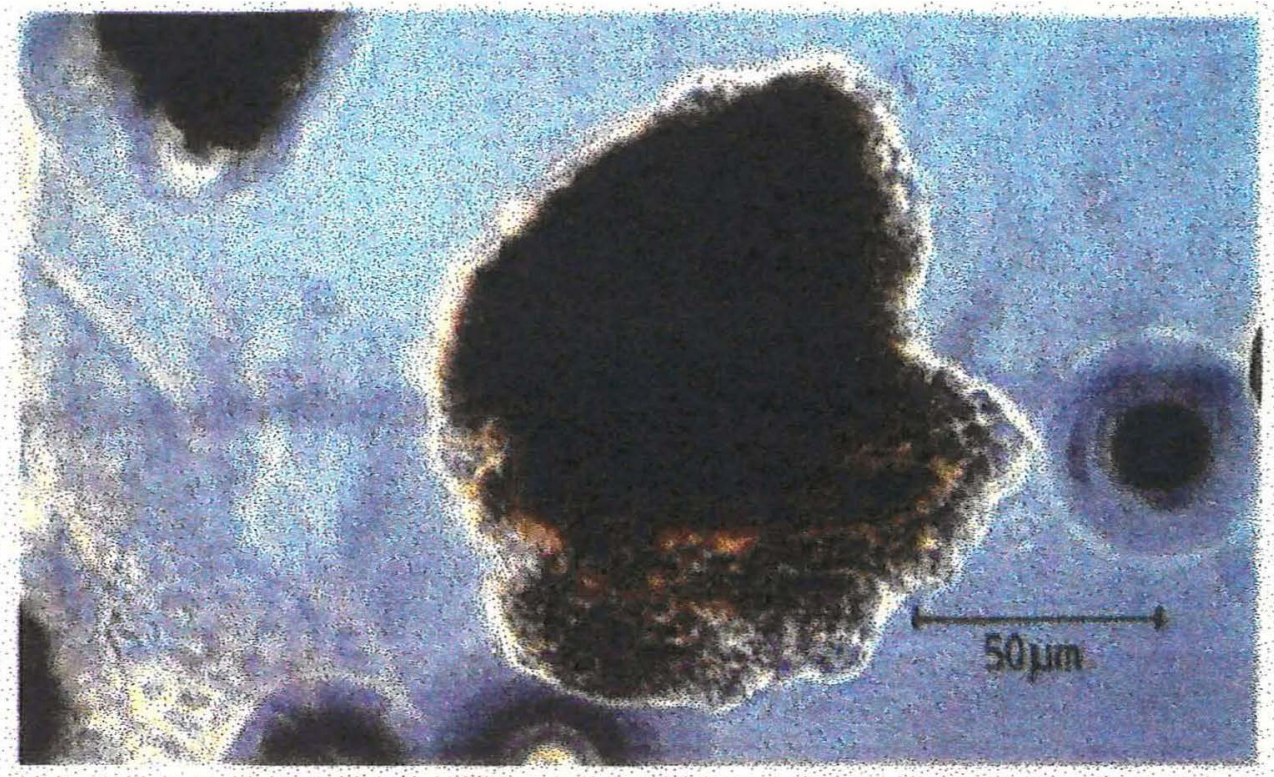

Figura 43

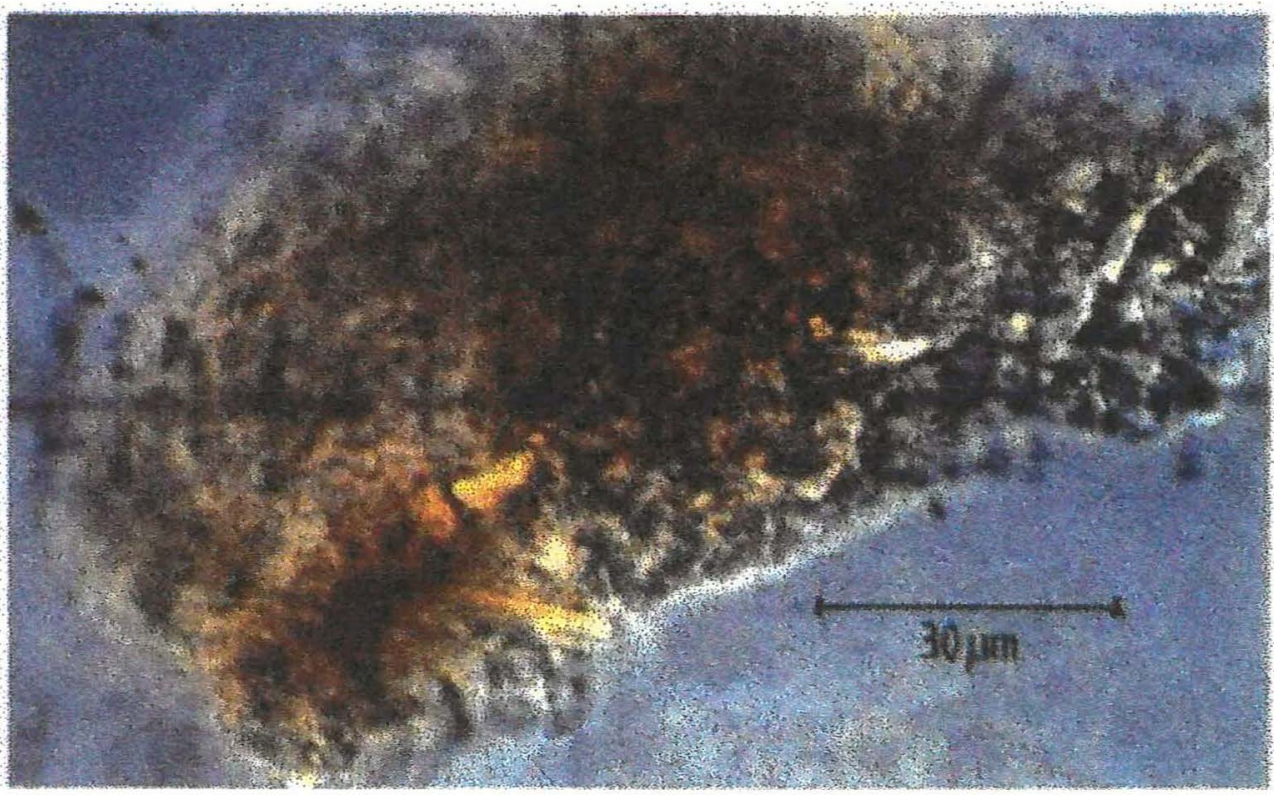

Figuras 43 e 44 - Fotografias obtidas por microscopia ótica de contraste de fase, mostrando o intemperismo da biotita em solos bem drenados. (Fração areia fina no horizonte $\mathrm{Cr}$ dos perfis 3 e 4 - NC e NCL). 


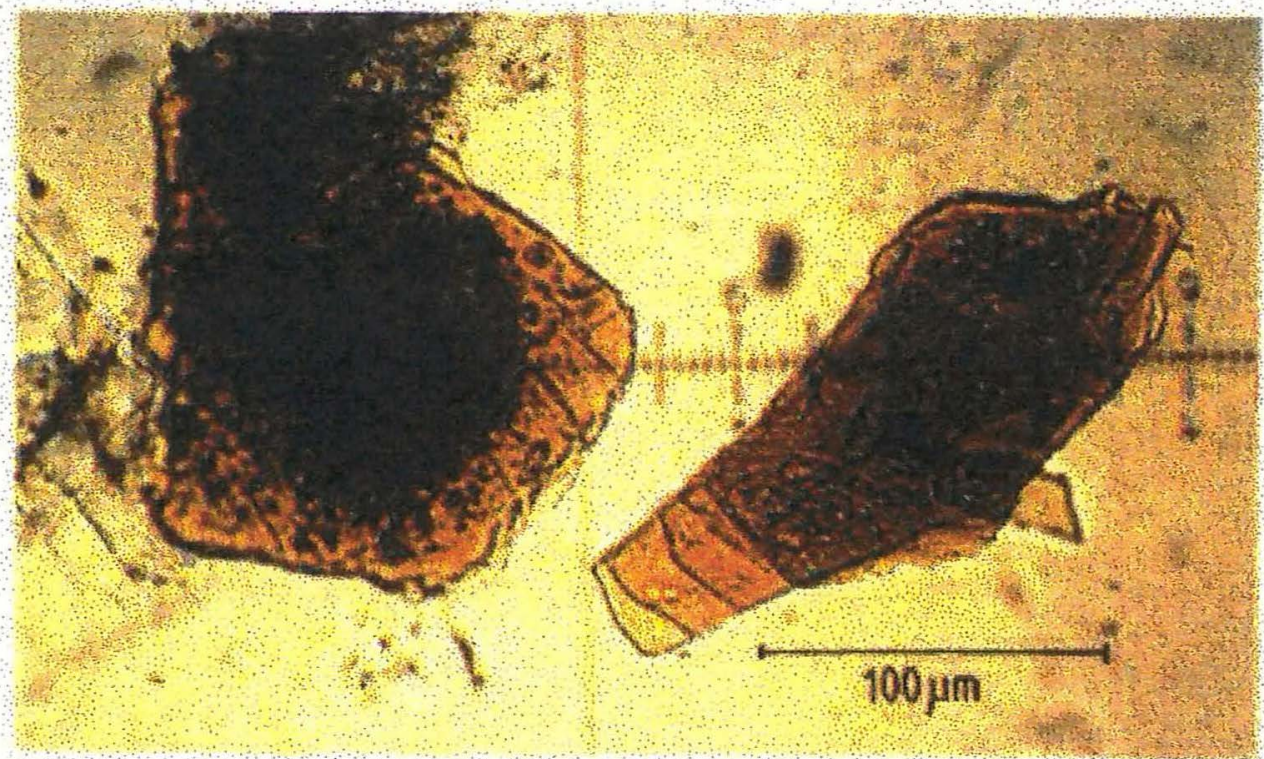

Figura 45- Fotografia obtida por microscopia ótica, mostrando minerais de biotita pouco alterados em solo bem drenado. Fração areia fina no horizonte $\mathrm{Cr}$ do perfil 3 (NC).

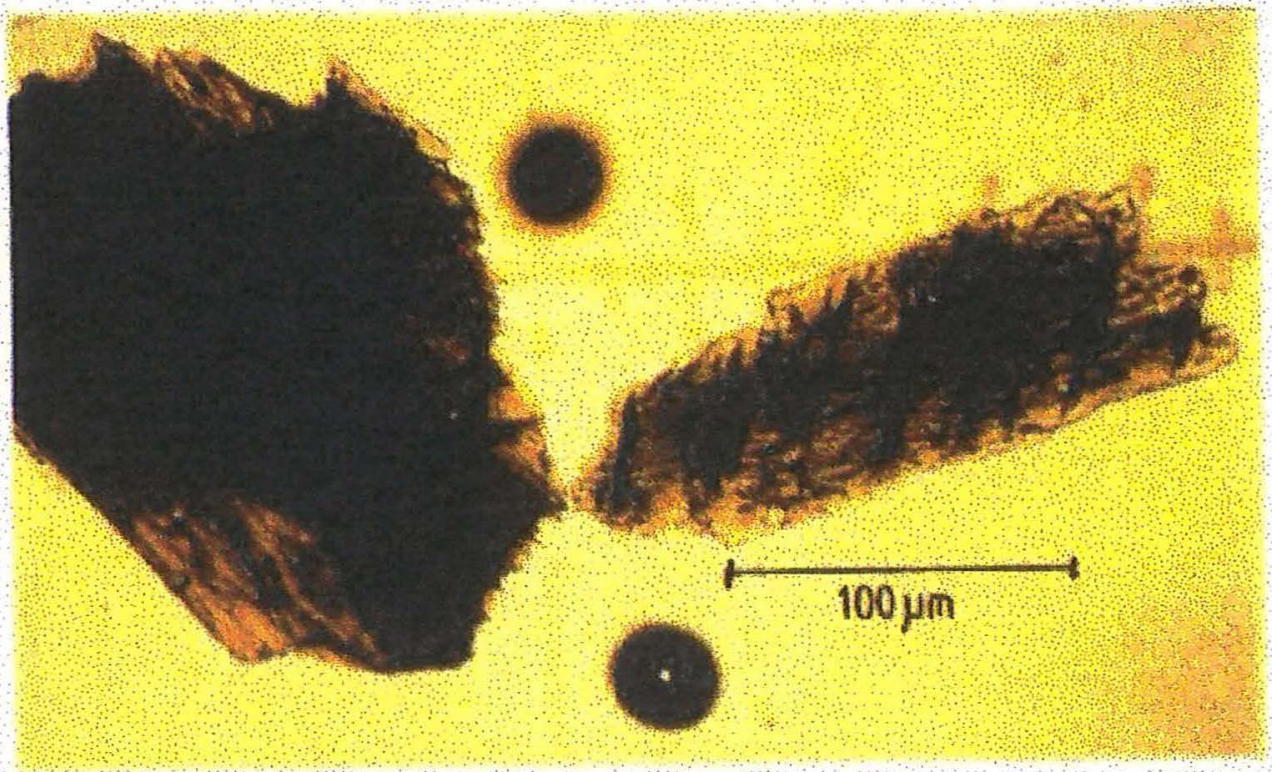

Figura 46 - Fotografia obtida por microscopia ótica, mostrando minerais de hornblenda pouco alterados em solo com drenagem deficiente. Fração areia fina no horizonte $\mathrm{Cr}$ do perfil $5(\mathrm{NCv})$. 


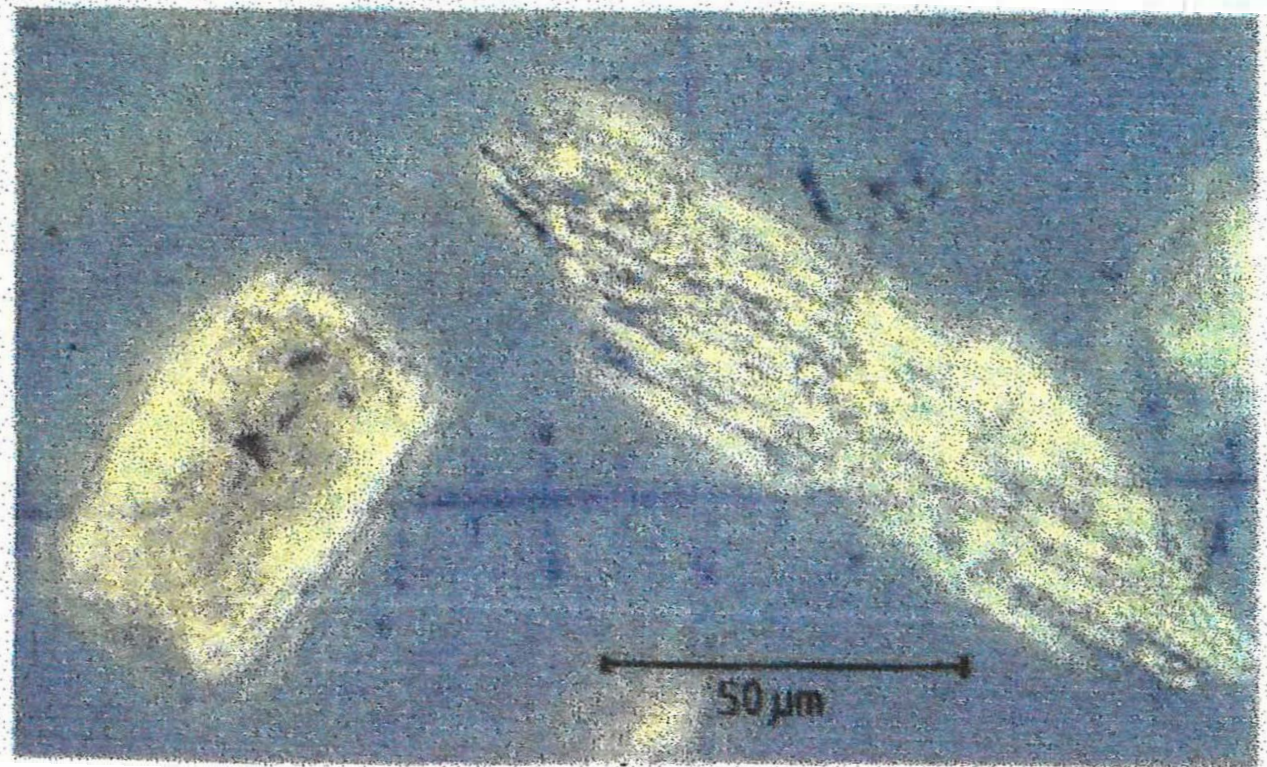

Figura 47 - Fotografia obtida por microscopia ótica de contraste de fase, mos trando pseudomorfoses de hornblenda em minerais de argila na fração areia fina no horizonte $\mathrm{Cr}$ do perfil $5(\mathrm{NCv})$.

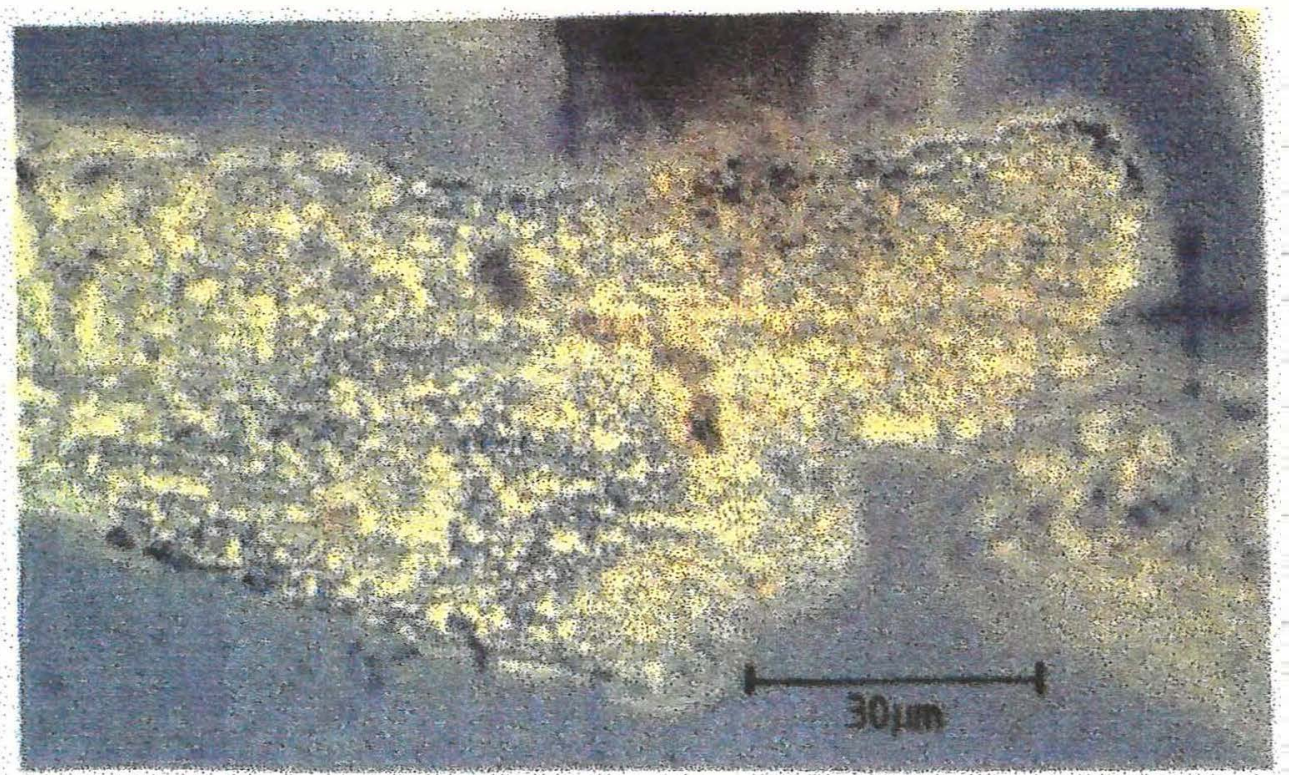

Figura 48 - Fotografia obtida por microscopia ótica de contraste de fase, mos trando pseudomorfose de hornblenda em minerais de argila na fração areia fina no horizonte $\mathrm{BC}$ do perfil 5 (NCv). 


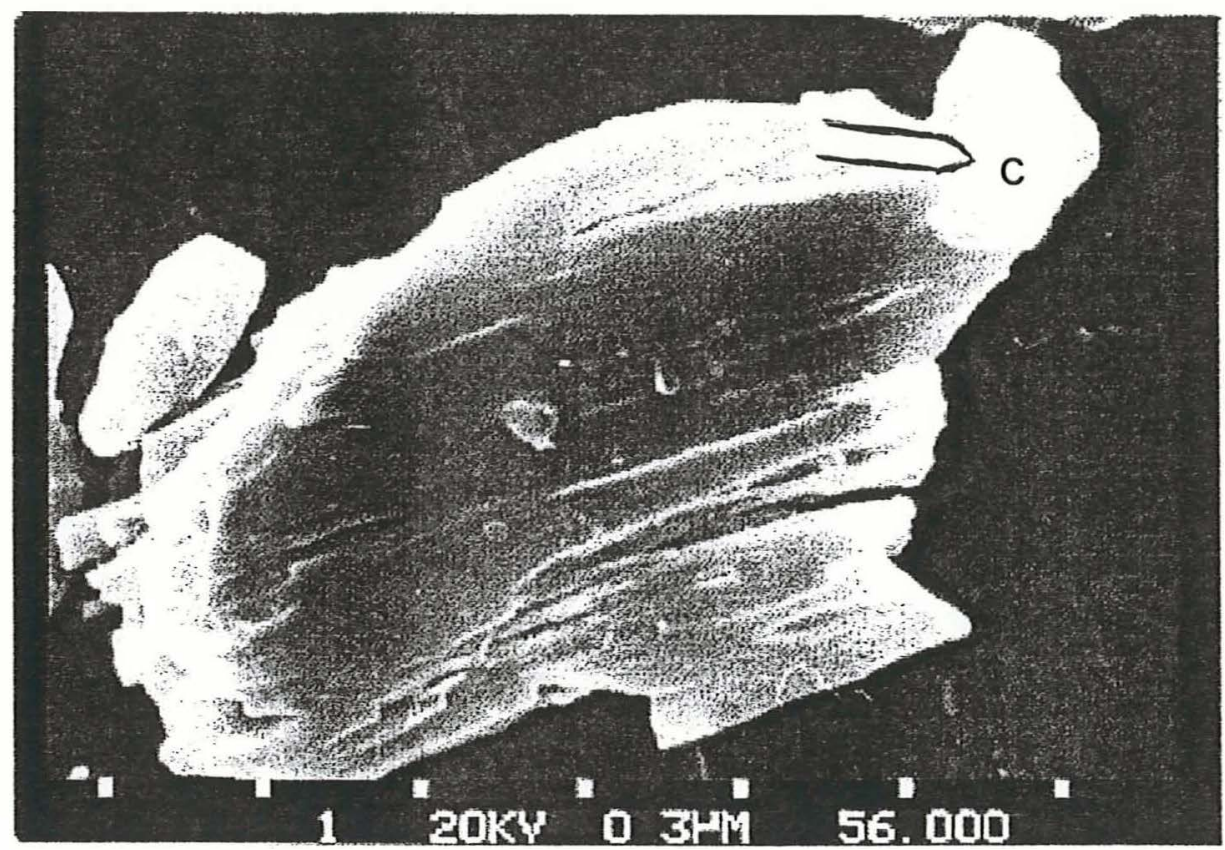

Figuras 49 e 50 - Fotografias obtidas por microscopia eletrônica de varredura mostrando o intemperismo da hornblenda em minerais de ar gila, na fração silte fino, nos horizontes $\mathrm{BC}$ e Bt do perfil 5 $(\mathrm{NCv})$.

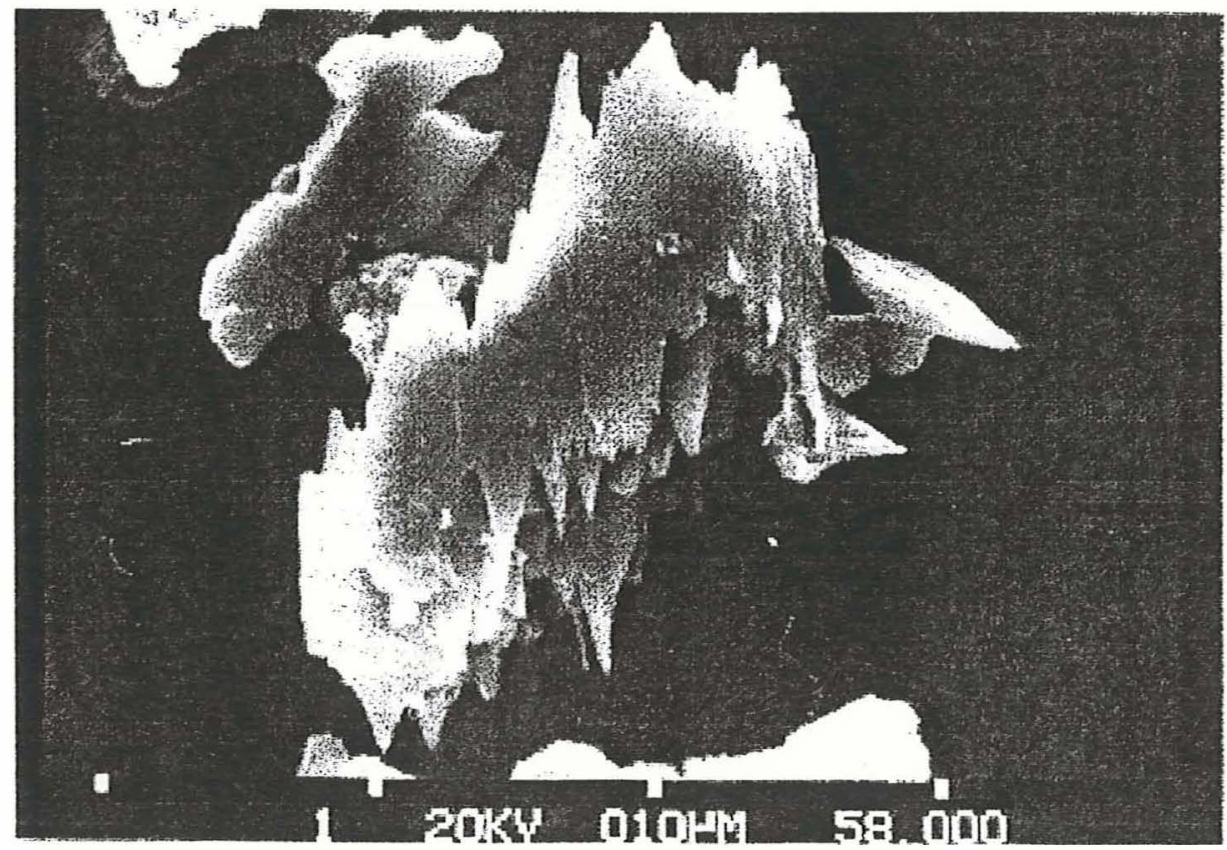

Figura 50 - Horizonte Bt. 
representam mais de $60 \%$ da composição mineralógica (tabela 15).

Principalmente nos horizontes $\mathrm{Cr}$ e $\mathrm{BC}$ encontram-se junto a essas hornblendas inalteradas as maiores quantidades de pseudo-formações de hormblendas em caulinita ou montmorilonita como ilustram as figuras $47 \mathrm{e}$ 48. Junto à separação de ácido silícico amorfo (opalização, vide áreas claras), ocorrem a formação de agregados altamente refrigentes (áreas escuras - manchas), que consistem de material caulinítico ou montmorilonítico. Nas pseudo-formações encontra-se também nontronita. As pseudomorfoses desintegram-se progressivamente no $\mathrm{Bt}$ no tamanho do silte e argila e elevam o teor de montmorilonita e caulinita. Nas figuras 49 e 50 na fração silte as transformações acima mencionadas não são mais evidentes. Em vez disso são bem reconhecidas, separadamente, partículas de homblenda, montmorilonita e caulinita. Essas fotografias obtidas por microscopia eletrônica de varredura mostram que nesse caso ocorreram mudanças consideráveis. As recém formadas partículas de caulinita, montmorilonita ou agregados de montmorilonita soltaram-se de forma clara dos restos de hornblenda durante a preparação do solo para a análise granulométrica (dispersão) e passaram para as partículas de argila. $\mathrm{O}$ remanescente de hornblenda representado na figura 49 , em cima à direita, contem meramente partes aparentemente hexagonais e que já podem ser designadas como cristais de caulinita. 


\section{Solos de Guaramiranga}

Os dois solos de Guaramiranga (perfis 6 e 7 - pg. 52), apesar de situados no planalto residual da serra de Baturité e derivados da mesma rocha, ocupam posições distintas no relevo. Enquanto o perfil 6 (PEa), está localizado na vertente úmida o perfil 7 (PVa), encontra-se na parte mais seca. $\mathrm{Na}$ vertente de barlavento, mais sujeita à morfogênese química, o contato com os terrenos das depressões sertanejas se faz através de pedimentos dissecados. Souza (1988), destaca que a morfologia dessa parte mais úmida é bastante dissecada, em forma de topos convexos, lombadas e mais raramente cristas. Tais condições ambientais propiciam uma maior ocorrência de Podzólicos Vermelho-Amarelos ou Escuros mais maduros revestidos primariamente por floresta subperenifólia ou plúvio-nebular. A vertente de sotavento (parte mais seca) onde está o perfil 7, as feições morfológicas são mais conservadas e têm alterações menos espessas. Segundo Souza (1988), o contato com a depressão sertaneja também se faz através de pedimentos, com rampas suaves, sem indícios de dissecação, com recobrimento de páleo-pavimentos grosseiros e predominância de morfogênese mecânica. Nessa vertente há uma tendência de solos Podzólicos Vermelho-Amarelos mais rasos, que se associam a Litólicos e Afloramentos de Rochas. A vegetação de caatinga já está presente nesse setor da serrra até aproximadamente $700 \mathrm{~m}$ de altitude.

Apesar dos argumentos teóricos expostos acima, as transformações mineralógicas verificadas no PEa e PVa estudados não são tão significativas, embora o perfil 6 possa ser considerado como mais maturo. Talvez a relativa 
pequena distância entre os dois pedons e a localização do perfil 7 próxima da transição vertente úmida-vertente seca (figura 6, pg. 52), tenham contribuido para tal fato.

As figuras 51 e 52 demonstram as quantidades dos minerais considerados mais intemperizáveis e a formação de argilo-minerais na argila e silte fino, em função da profundidade, nos dois solos. Verifica-se que as proporções de caulinita e ilita originadas no horizonte de máximo teor de argila, praticamente se igualam com o decréscimo de biotita e feldspato nas frações areia e silte grosso desse horizonte, quando se estabelece um balanço entre os horizontes $2 \mathrm{CB}$ e $2 \mathrm{Btl}$ no PEa e entre $\mathrm{Cr}$ e Btf2 no PVa. Ainda corroborando com o citado, um balanço de formação de argila comparando os mesmos horizontes e usando-se os dados da distribuição de partículas por tamanho (tabela 2), resulta em valores de $-1 \%$ e $-3 \%$ para os perfis 6 e 7 respectivamente. Desse modo a gênese do horizonte $B$ textural, também nos perfis da topossequência Guaramiranga, parece ser essencialmente através da alteração de minerais "in situ". As prováveis sequências de alteração seriam: (a) mica $\Rightarrow$ ilita $\Rightarrow$ caulinita e (b) plagioclásios $\Rightarrow$ caulinita. Os teores relativos de caulinita do PEa nas frações argila e silte fino são superiores aos do PVa, o contrário se verifica com as quantidades de ilita nos dois solos, daí a provável maior maturidade do perfil 6 o que também foi elucidada através de outros atributos mencionados e já discutidos.

As figuras 53 a 61 mostram processos de transformações mineralógicas nos dois perfis. Como já citado, o material originário dos solos é um saprolito de gnaisse micáceo (muscovita e biotita) enriquecido de feldspato (albita). 


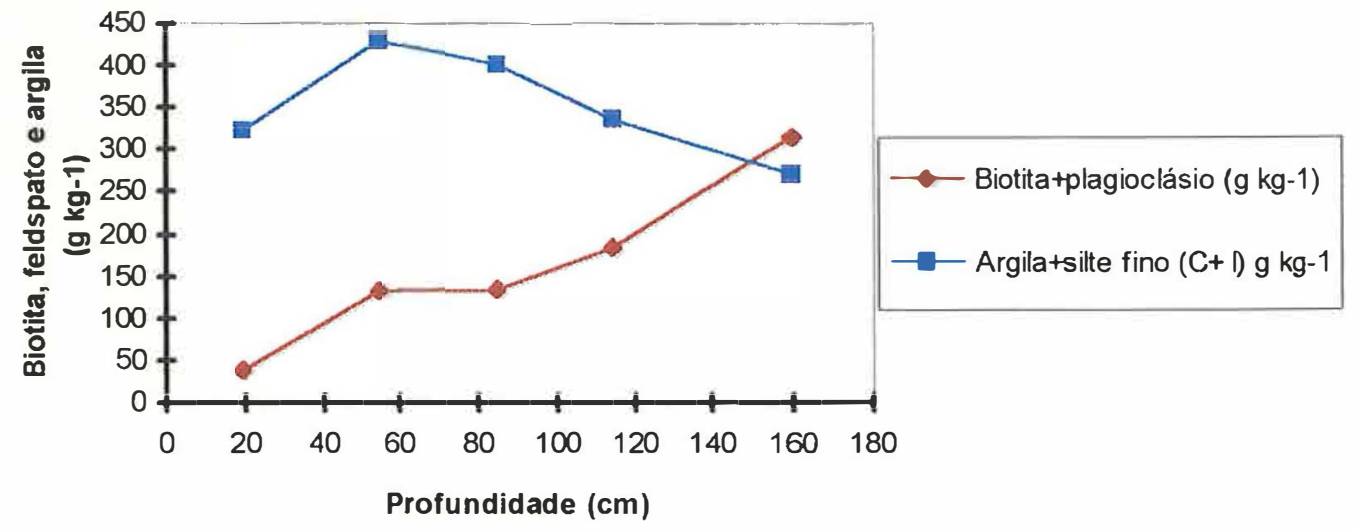

Figura 51 - Distribuição de minerais intemperizáveis da fração areia e caulinita + ilita nas frações silte fino e argi la, com a profundidade, no perfil 6 (PEa).

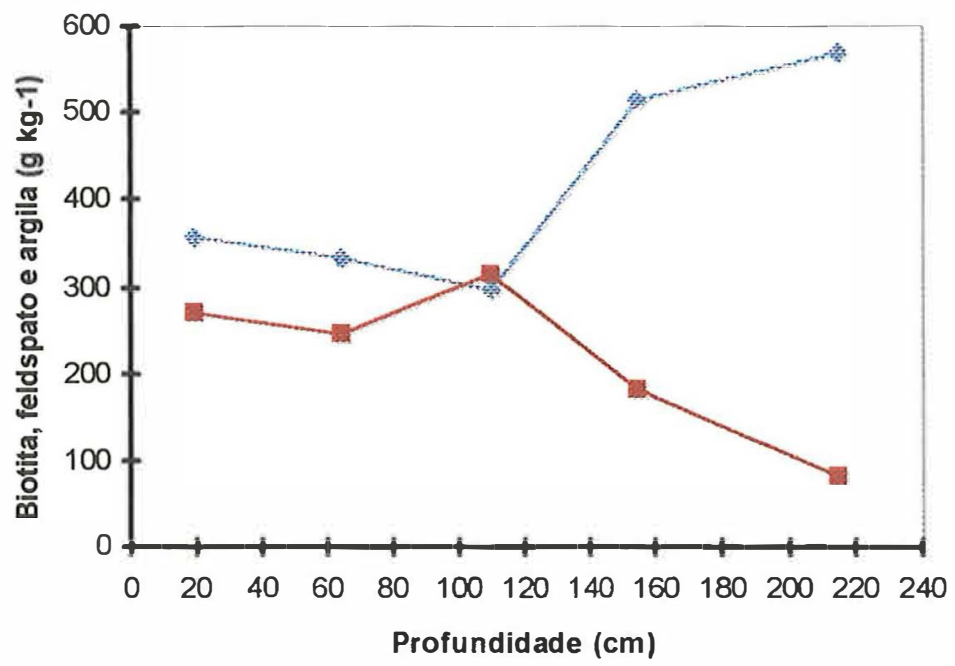

Figura 52 - Distribuição de minerais intemperizáveis da fração areia e caulinita + ilita nas frações silte fino e argi la, com a profundidade, no perfil 7 (PVa). 


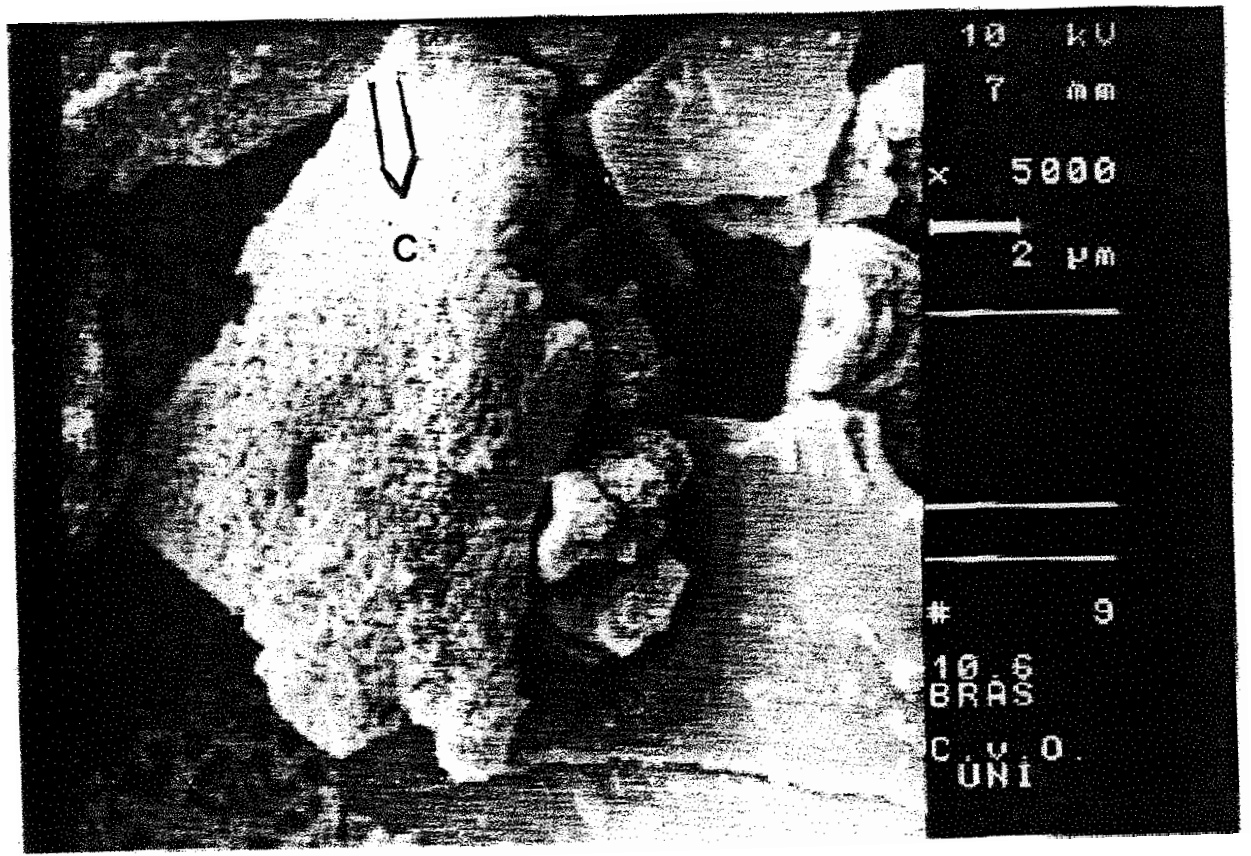

Figura 53

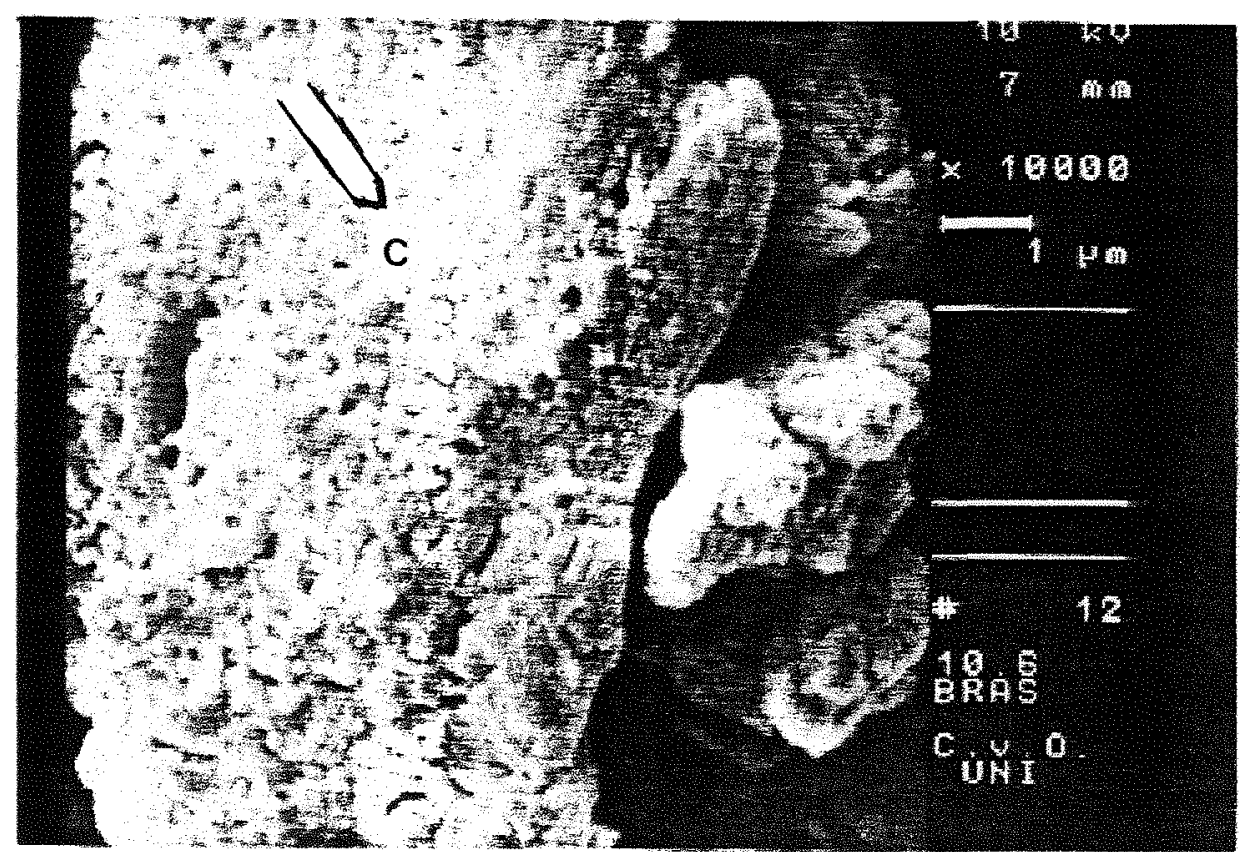

Figuras 53 e 54 - Fotografias obtidas por microscopia eletrônica de varredura, mostrando pseudomorfoses de feldspato (albita) para caulini ta, no horizonte $2 \mathrm{CB}$ do perfil 6 ( $\mathrm{PEa})$. 


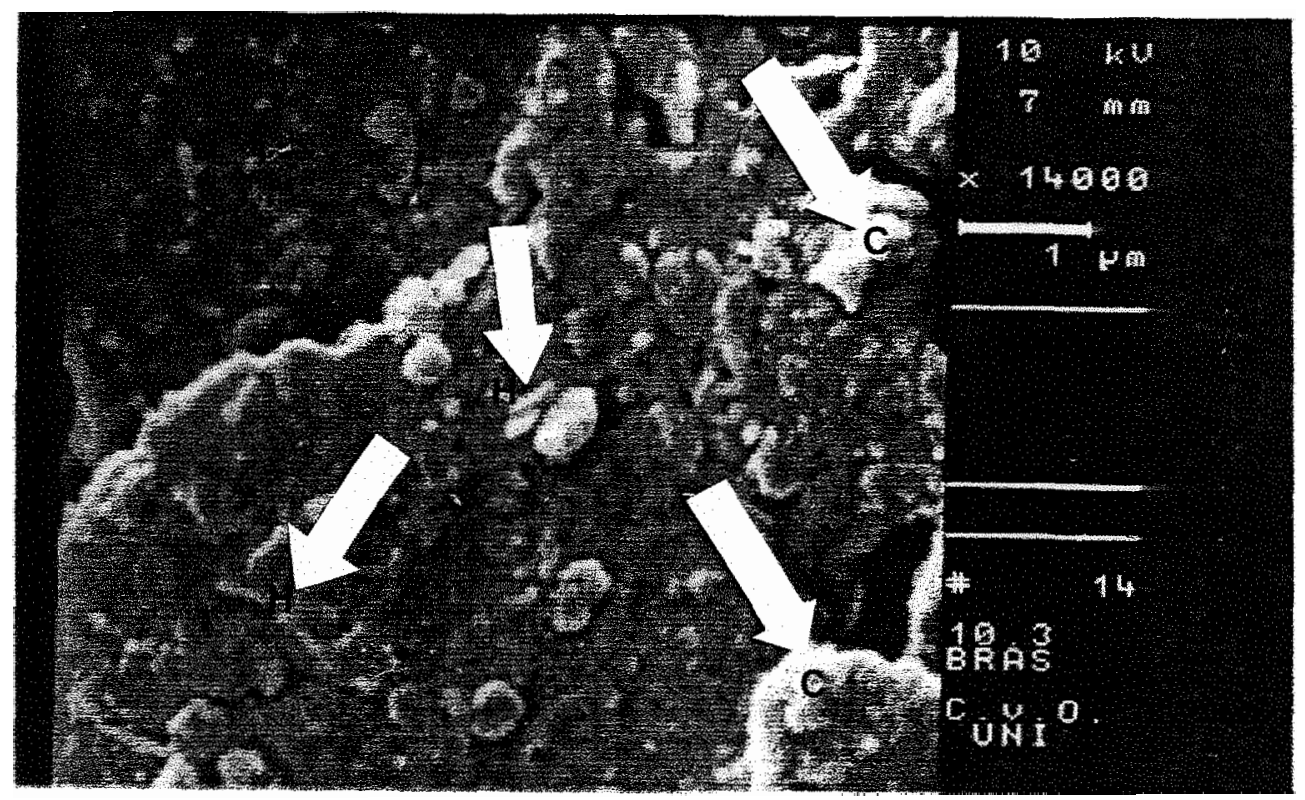

Figura 55

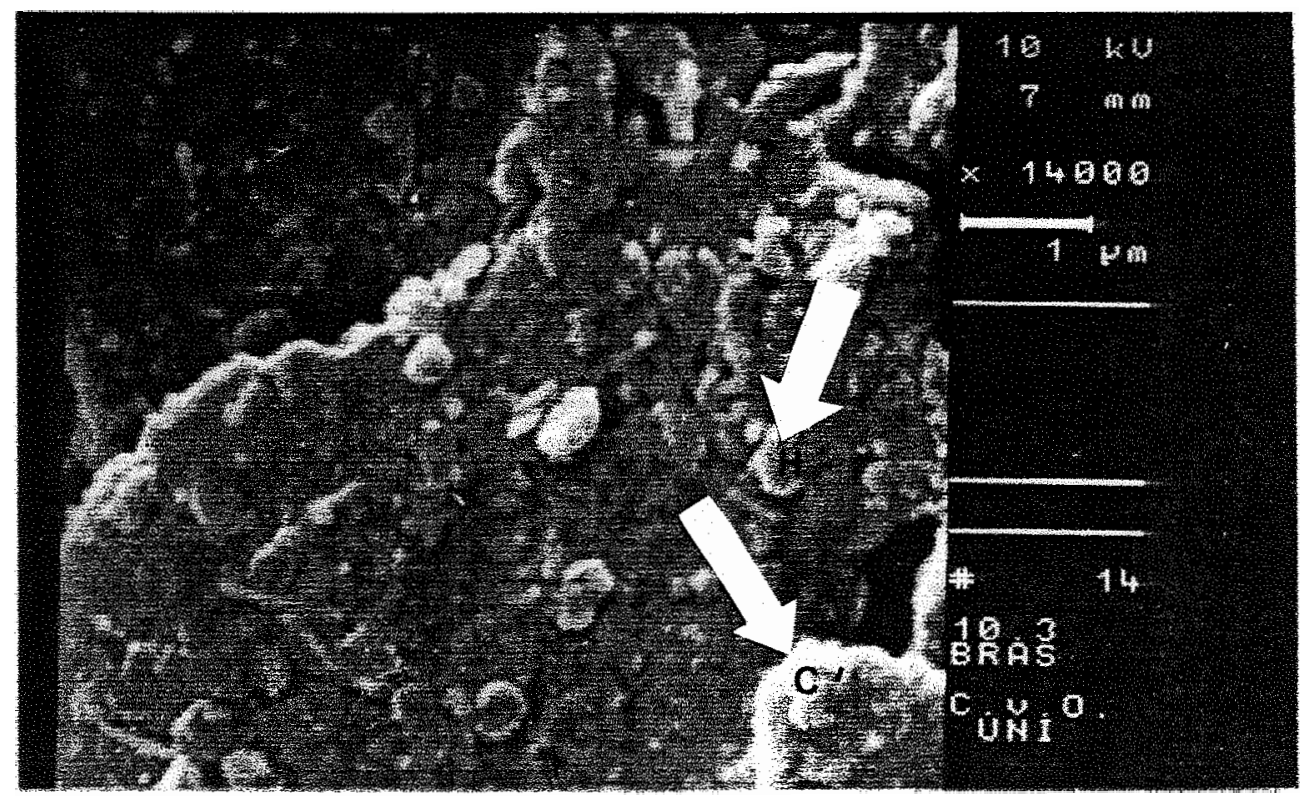

Figuras 55 e 56 - Fotografias obtidas por microscopia eletrônica de varredura, mostrando a transformação de mica em caulinita(C) e haloi sita $(\mathrm{H})$, no horizonte $\mathrm{Bt}$ do perfil $6(\mathrm{PEa})$. 


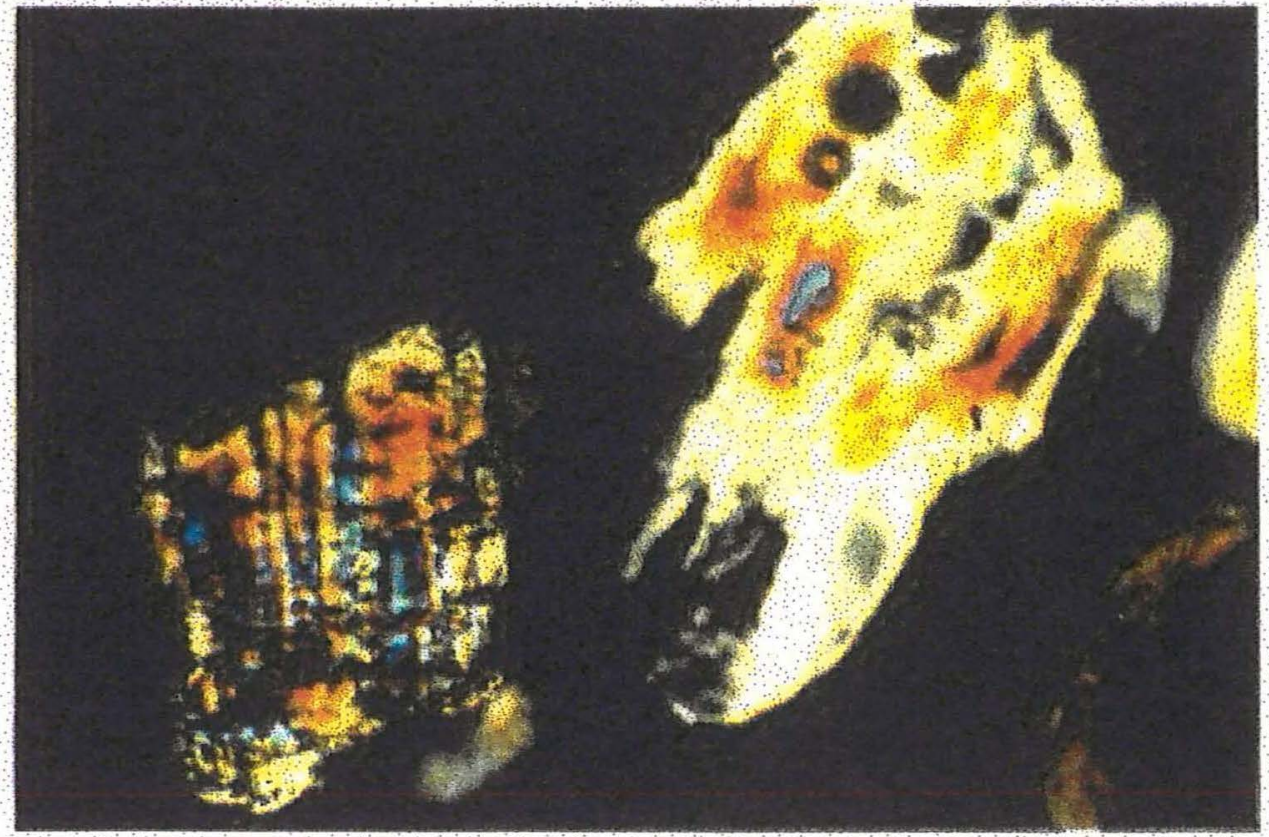

Figura 57

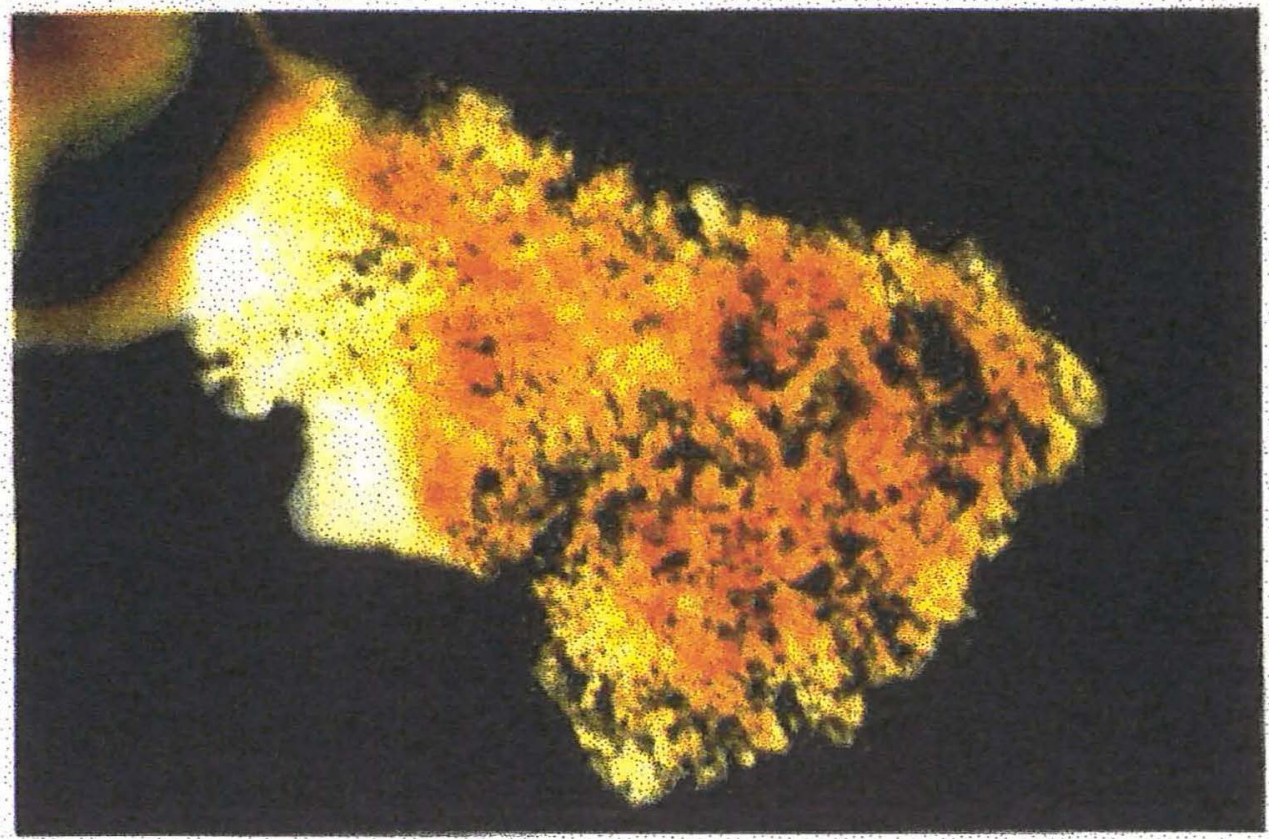

Figuras 57 e 58 - Fotografias obtidas por microscopia ótica de polarização, mostrando o intemperismo pedoquímico de grãos de felds patos, na fração silte grosso no perfil 7 (PVa). 
Nos dois perfis as frações areia e silte do horizonte $C$, são constituidas predominantemente por micas (aproximadamente metade biotita e metade muscovita) seguidas de quartzo e feldspatos (plagioclásios). No PVa o teor de feldspato é bem maior do que o de quartzo. A biotita sob luz polarizada em parte já mostra a separação do ferro oxidado na superficie.

As fotomicrografias presentes nas figuras 53 e 54 , apresentam pseudomorfoses de feldspato para caulinita, obtidas por microscopia eletrônica de varredura no horizonte $2 \mathrm{CB}$ do perfil 6 . Nestas, já há cristais de caulinita no tamanho da argila fina $(<0,2 \mu \mathrm{m})$, veja a forte ampliação da foto. A mica apresenta-se ainda bem inalterada (veja a parte superior da figura 53). No silte e areia do horizonte Bt do perfil 6, as quantidades de mica diminuem embora ainda constituam uma parte relativamente significante da mineralogia dessas frações. Os produtos do intemperismo são representados em grande parte como caulinita, ilita e provavelmente também haloisita que se transforma em caulinita (veja partículas tubulares nas figuras 55 e 56). Na fração argila existe caulinita e em menor quantidade ilita. Os feldspatos na forma de pseudomorfoses para caulinita, presentes nas partículas silte e areia, não mais existem, ou seja são distinguidas no enriquecimento da fração argila. Desse modo, os feldspatos com base em seu intemperismo geoquímico, contibuem especialmente para a extensão da caulinitização.

No perfil 7, a muscovita e a biotita estão como no perfil 6, ainda bem preservadas. No material originário (horizonte $\mathrm{Cr}$ ), observa-se também a presença de feldspato não intemperizado geoquimicamente (caulinitizado), e 


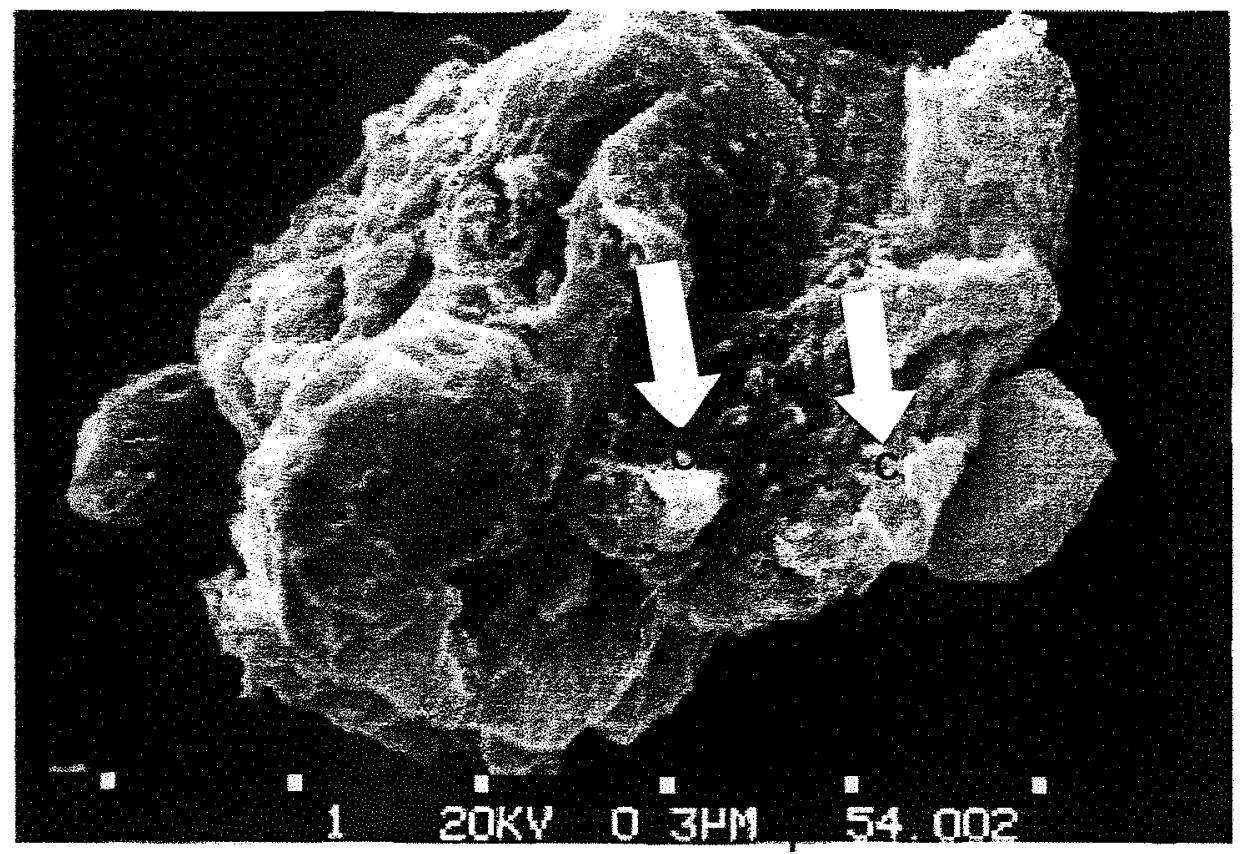

Figuras 59 e 60 - Fotografias obtidas por microscopia eletrônica de varredu ra, mostrando a intemperização de feldspato na fração sil te no horizonte $\mathrm{Cr}$ do perfil 7 (PVa).

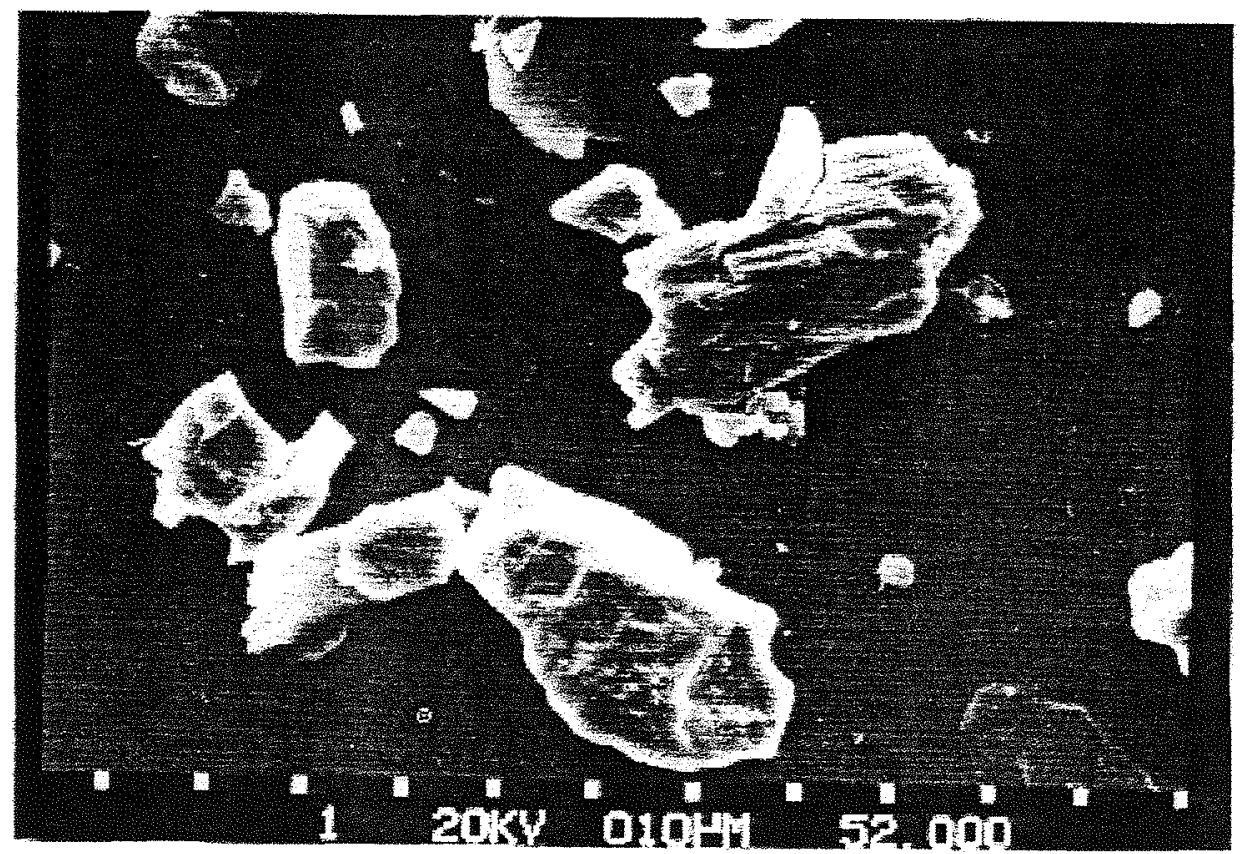

Figura 60 - Feldspato pouco alterado. 


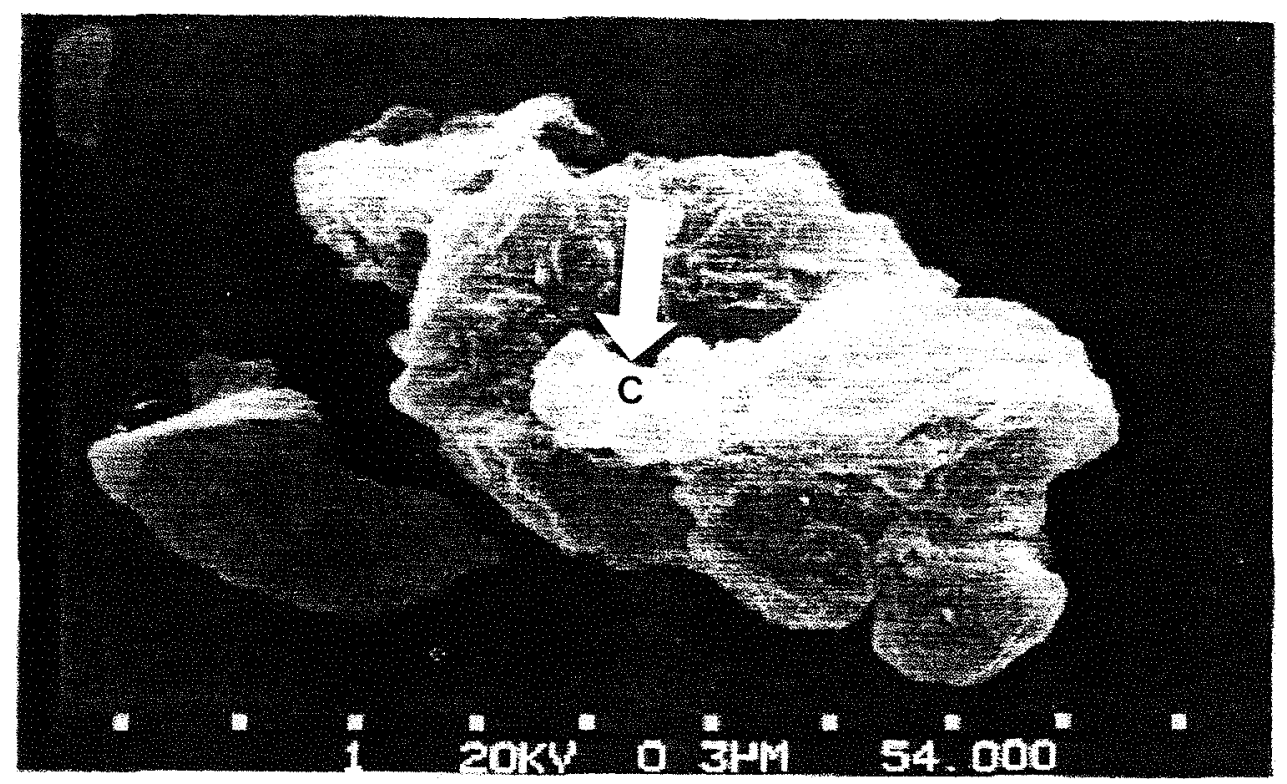

Figura 61 - Fotografia obtida por microscopia eletrônica de varredura, mos trando a intemperização de feldspato, na fração silte, no horizon te Btf2 do perfil 7 (PVa).

reconhecido como material ainda inalterado (figura 58). A figura 57, entretanto, mostra um forte intemperismo de feldspato para caulinita no $\mathrm{Cr}$.

Especialmente na fração areia do horizonte Btf2 existe nitidamente menos biotita e feldspato. Ambos os tipos de minerais, contribuem assim, para a formação de argila. Enquanto a biotita se altera para ilita, os feldspatos se transformam em caulinita. Ao mesmo tempo acontece o intemperismo pedoquímico dos feldspatos, respectivamente uma caulinitização manifestada apenas próxima à superfície, atingindo apenas parte do mineral (figuras 59, 60 e 61). Na areia fina e silte grosso, notadamente no horizonte Btf, são encontradas pequenas quantidades de goetita e lepidocrocita, uma indicação sobre o início e/ou evolução do processo de plintização. 


\section{Solos de Tauá}

Está constituida pelos perfis 8 (PL), que ocupa as posições de topo e encosta e pelo perfil 9 (aluvial), com estratificação de camadas relativas ao holoceno e localizado na parte mais baixa do relevo.

As figuras 62 e 63 demonstram as quantidades de mmerais intemperizáveis na fração areia e a formação de minerais de argila no silte fino e argila, em função da profundidade. Verifica-se que o decréscimo dos minerais de mais fácil intemperização (hornblenda, biotita e plagioclásios) do horizonte $2 \mathrm{Cr}$ para o $2 \mathrm{Btn}$ praticamente nivela-se ao acréscimo de minerais de argila no B textural, quando comparado com a quantidade desses mesmos minerais no $2 \mathrm{Cr}$. Na fração areia grossa o teor de plagioclásios diminui de $200 \mathrm{~g} \mathrm{~kg}^{-1}$ no $2 \mathrm{Cr}$ para $140 \mathrm{~g} \mathrm{~kg}^{-1}$ no 2Btn; o de hornblenda de $25 \mathrm{~g} \mathrm{~kg}^{-1}$ para $3 \mathrm{~g} \mathrm{~kg}^{-1}$ e o de biotita de $90 \mathrm{~g} \mathrm{~kg}^{-1}$ para $0 \mathrm{~g} \mathrm{~kg}^{-1}$. As quantidades desses silicatos primários, são desse modo, reduzidas em sua totalidade em torno de $172 \mathrm{~g} \mathrm{~kg}^{-1}$. A esses dados devem ser somados um decréscimo dos teores de hornblenda e biotita na areia fina de $80 \mathrm{~g} \mathrm{~kg}^{-1}$. Portanto, para uma diminuição total dos minerais intemperizáveis na fração areia de $252 \mathrm{~g} \mathrm{~kg}^{-1}$, se contrapõe um aumento das quantidades de caulinita + montmorilonita de $243 \mathrm{~g} \mathrm{~kg}^{-1}$ nas frações silte fino e argila do horizonte $2 \mathrm{Btn}$. Desse modo, o enriquecimento de argila no $2 \mathrm{Btn}$, pode ser essencialmente explicado do ponto de vista quantitativo, pela decomposição ou transformação de plagioclásios, hornblenda e biotita (tabela 18). As figuras 64 e 65 mostram em fotomicrografias processos de transformações mineralógicas da biotita no perfil 8 (PL). 


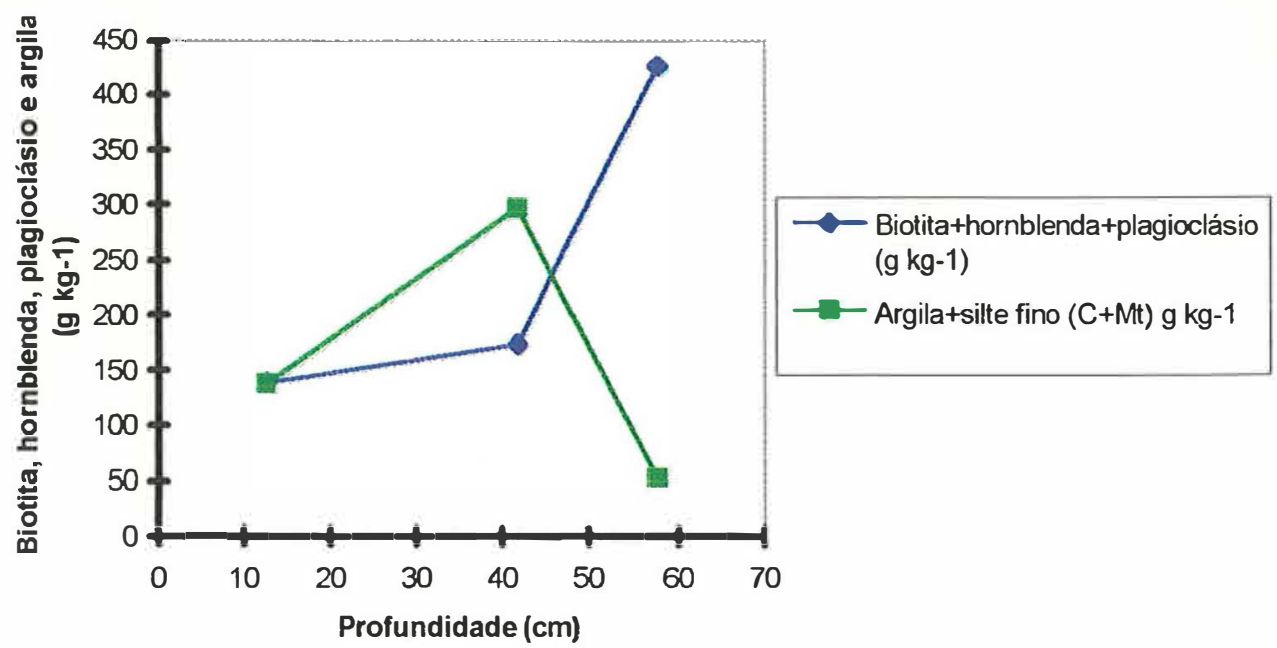

Figura 62 - Distribuição de minerais intemperizáveis da fração areia e caulinita + montmorilonita nas frações silte fino e argila, com a profun didade, no perfil 8 (PL)
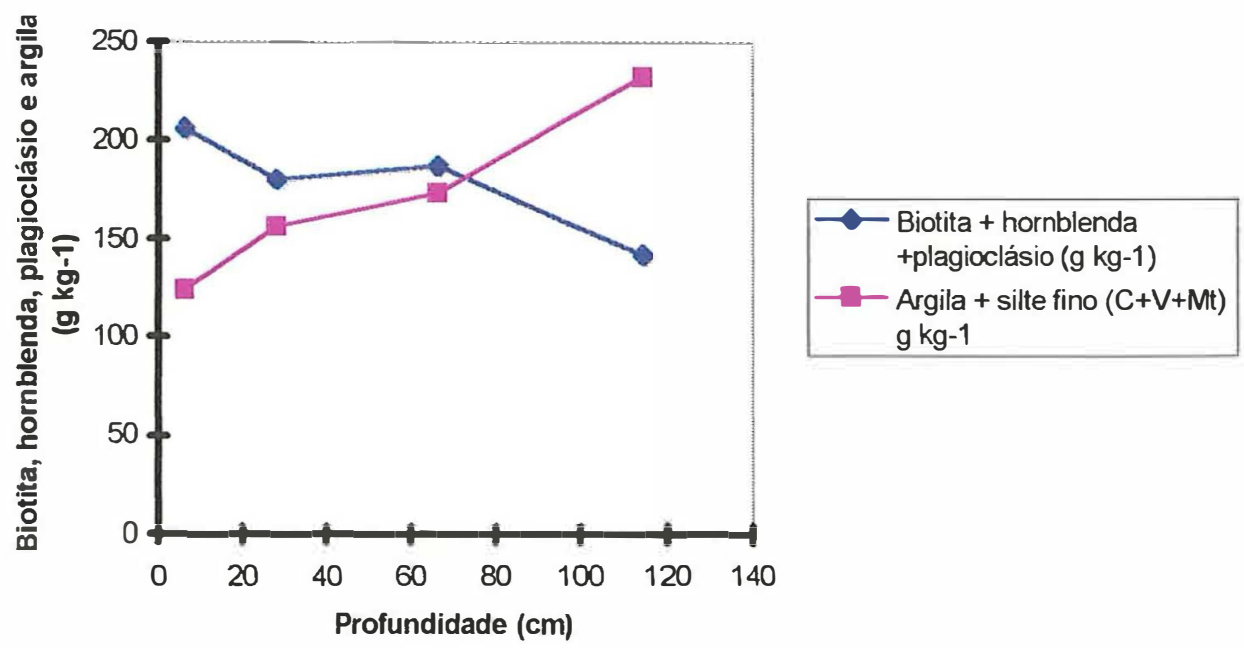

Figura 63 - Distribuição de minerais intemperizáveis da fração areia e caulinita + montmorilonita + vermiculita nas frações silte fino e argila, com a profundidade, no perfil 9 (Aluvial). 


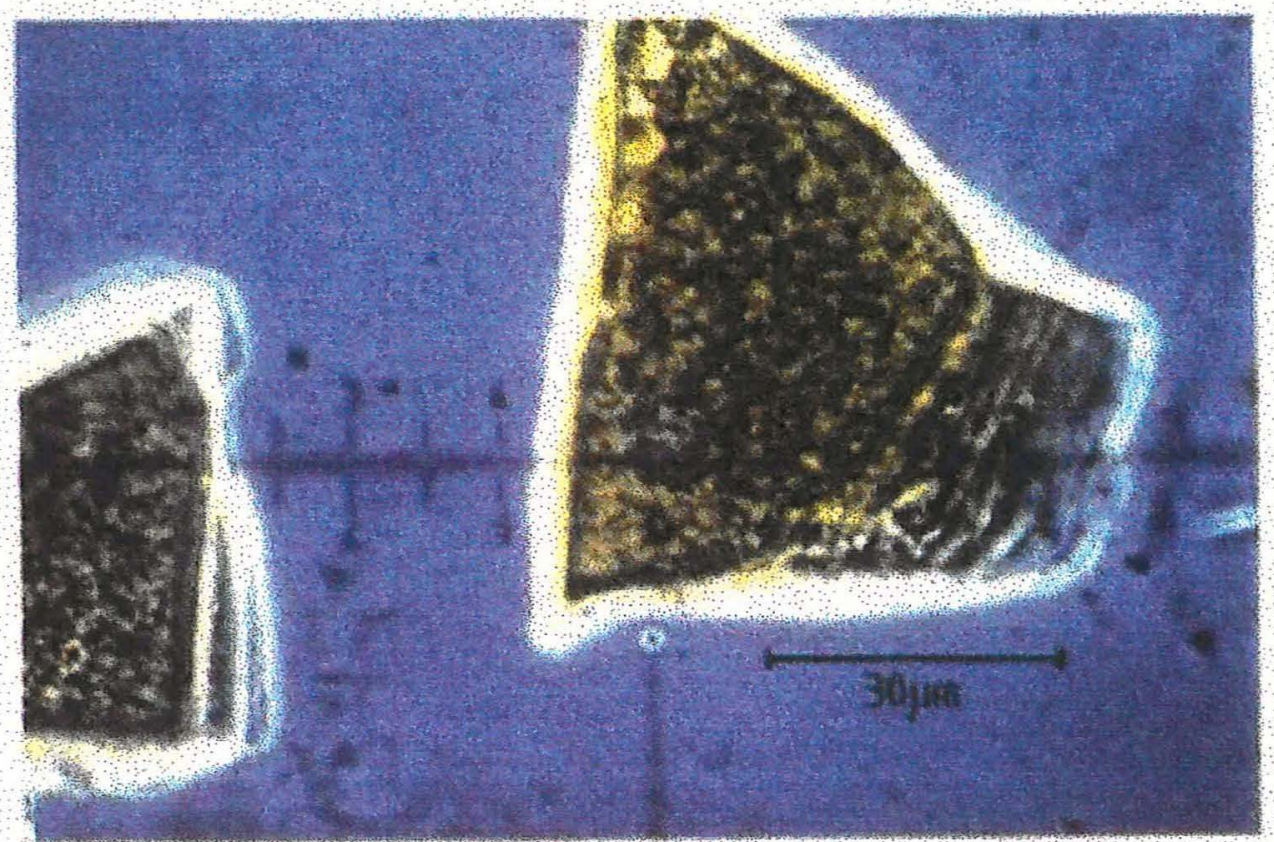

Figura 64 - Fotografia obtida por microscopia ótica de contraste de fase, mos trando o intemperismo da biotita em solo com drenagem deficien te. Fração areia fina no horizonte $\mathrm{Cr}$ do perfil 8 (PL).

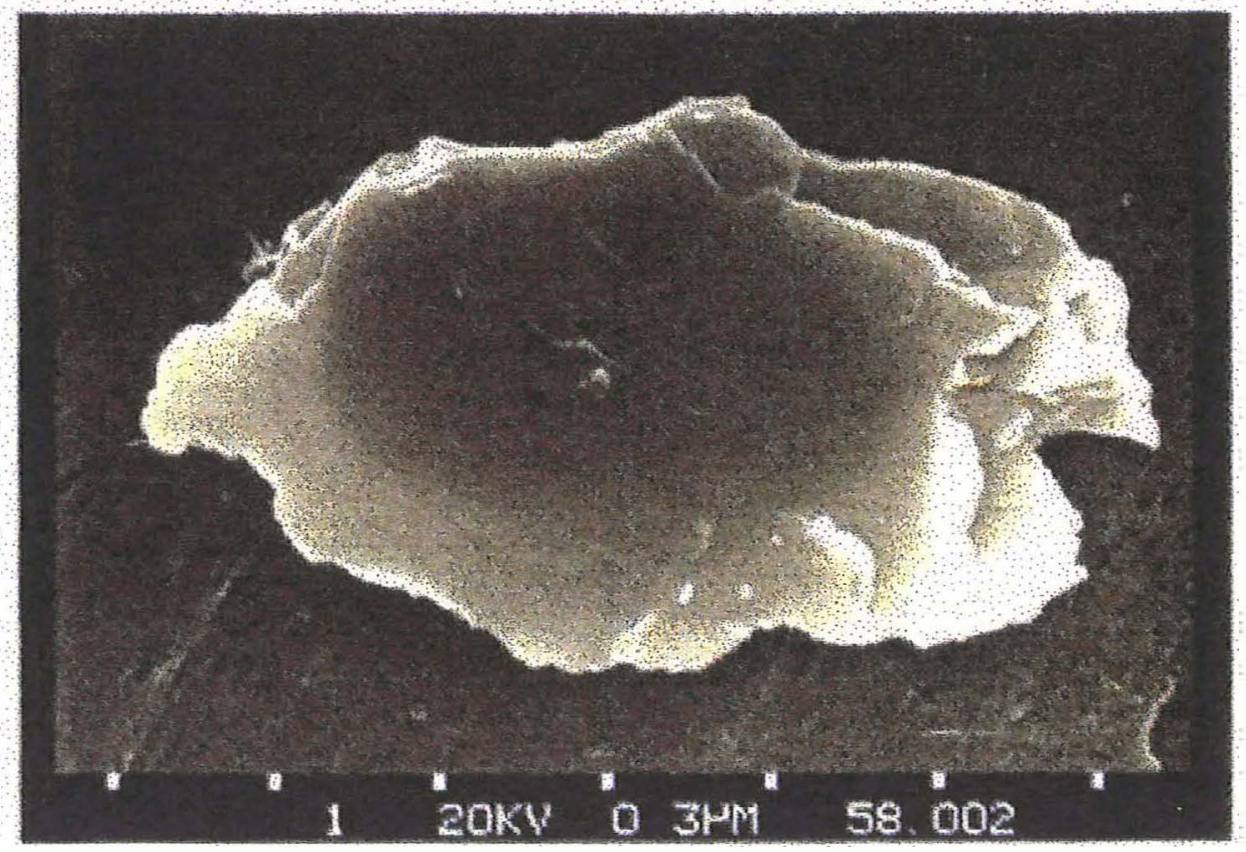

Figura 65 - Fotografia obtida por microscopia eletrônica de varredura, mos trando o intemperismo da biotita em solo com drenagem impedi da. Fração silte fino no horizonte Cr do perfil 8 (PL). 
Nesse caso, a alteração da biotita ocorre sob condições imperfeitamente drenadas. Portanto, não há uma separação rápida dos óxidos de ferro e uma imediata caulinitização, mas sim, primeiramente, um alargamento do espaçamento basal e a formação de vermiculita ou montmorilonita, que conduzem ao enriquecimento desses argilo-minerais no horizonte $2 \mathrm{Btn}$.

No perfil 9 (anexo B), de natureza alóctone, as quantidades dos minerais variam dentro de limites de acordo com a natureza do material de origem. Desse modo, analisando-se a figura 63 e fazendo-se um balanço entre perdas e ganhos em função da profundidade, não se encontra bases quantitativas para o estabelecimento de transformações mimerais pedoquímicas, que expliquem o enriquecimento em argila de algum horizonte do perfil a partir de minerais primários presentes em outro horizonte. Portanto, transformações de biotitas em vermiculitas e de hornblendas em caulinita por exemplo, provavelmente são herdadas.

\section{Solos da BR - 222}

Estão localizados ao longo da BR-222, na direção Fortaleza - Sobral (figura 8, pg. 54). Embora no sistema americano de classificação (EUA, 1992), estejam classificados como Alfissolos, no sistema brasileiro, taxonomicamente, se correlacionam com PVe (perfil 10) e Solonetz Solodizado (perfil 11). As figuras 66 e 67, apresentam as proporções de minerais intemperizáveis nas frações mais grosseiras e a gênese de argilominerais, no silte fino e argila de acordo com a profundidade. 

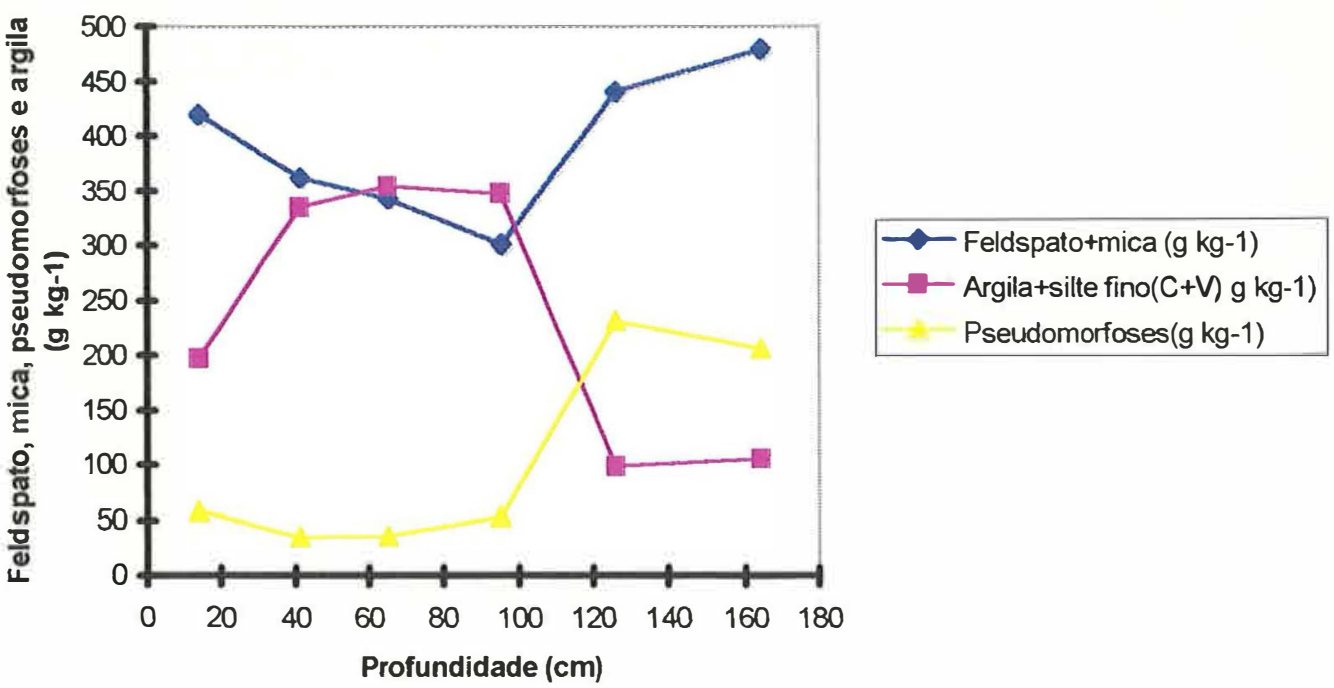

Figura 66 - Distribuição de minerais intemperizáveis da fração areia e caulinita + vermiculita + pseudomorfoses nas frações silte fino e ar gila, com a profundidade, no perfil $10(\mathrm{PVe})$.
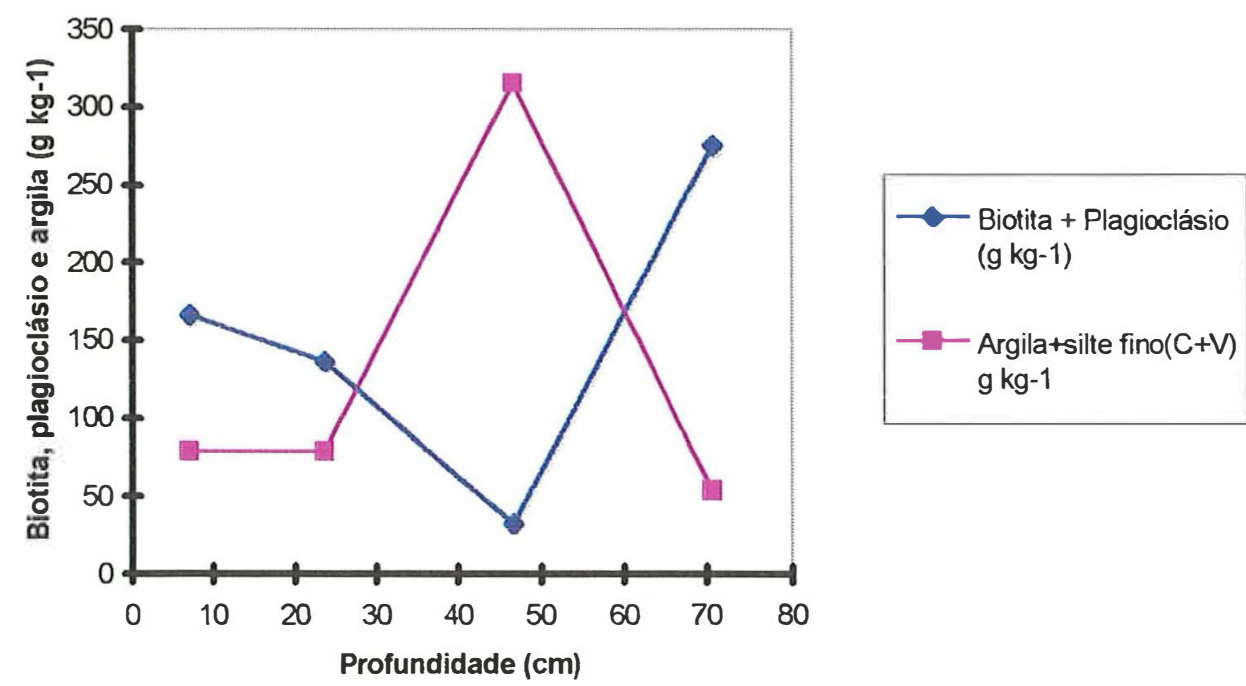

Figura 67 - Distribuição de minerais intemperizáveis da fração areia e caulinita + vermiculita nas frações silte fino e argila, com a profun didade, no perfil 11 (SS). 


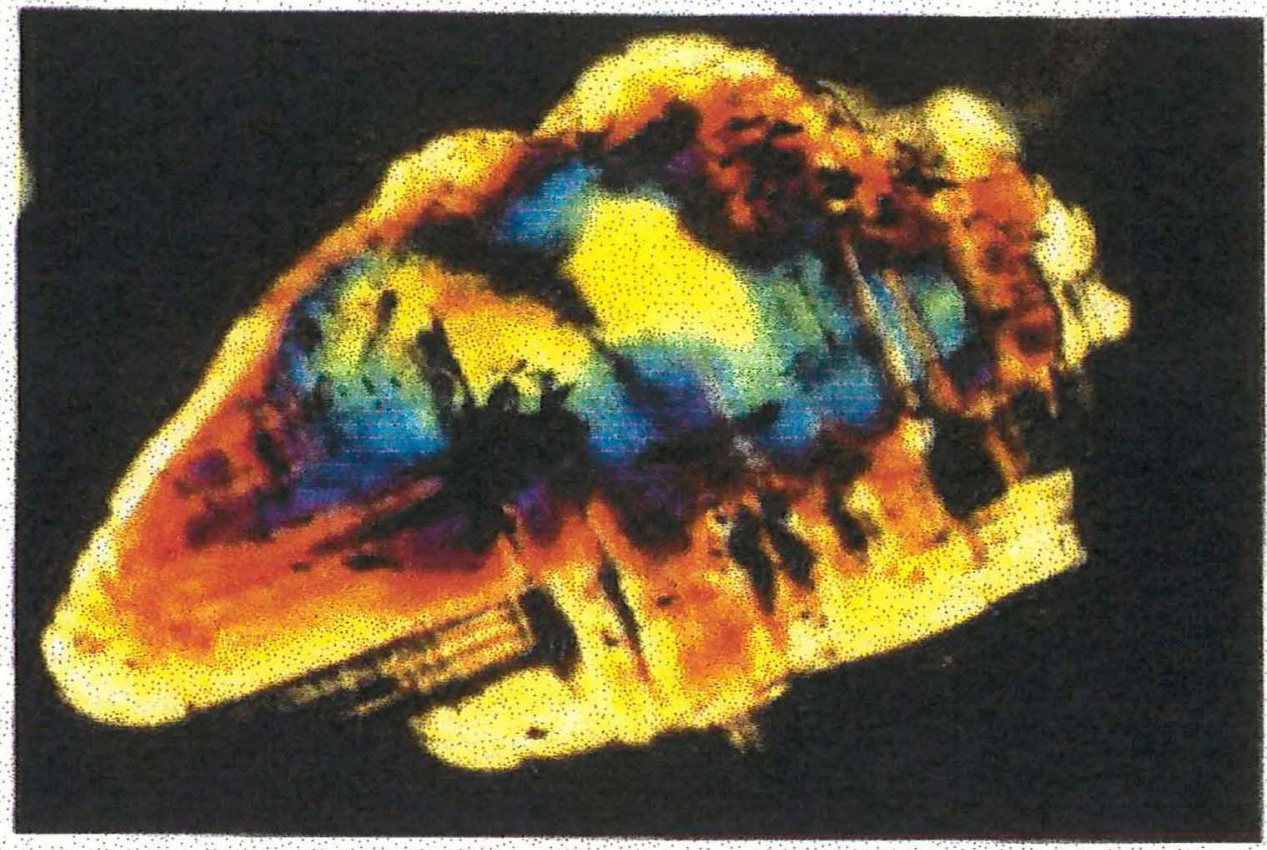

Figura 68 - Fotografia obtida por microscopia ótica de polarização, mostrando um feldspato ( microclínio ), praticamente inalterado, na fração are ia grossa no horizonte $\mathrm{Bt} 2$ do perfil 10 (PVe).

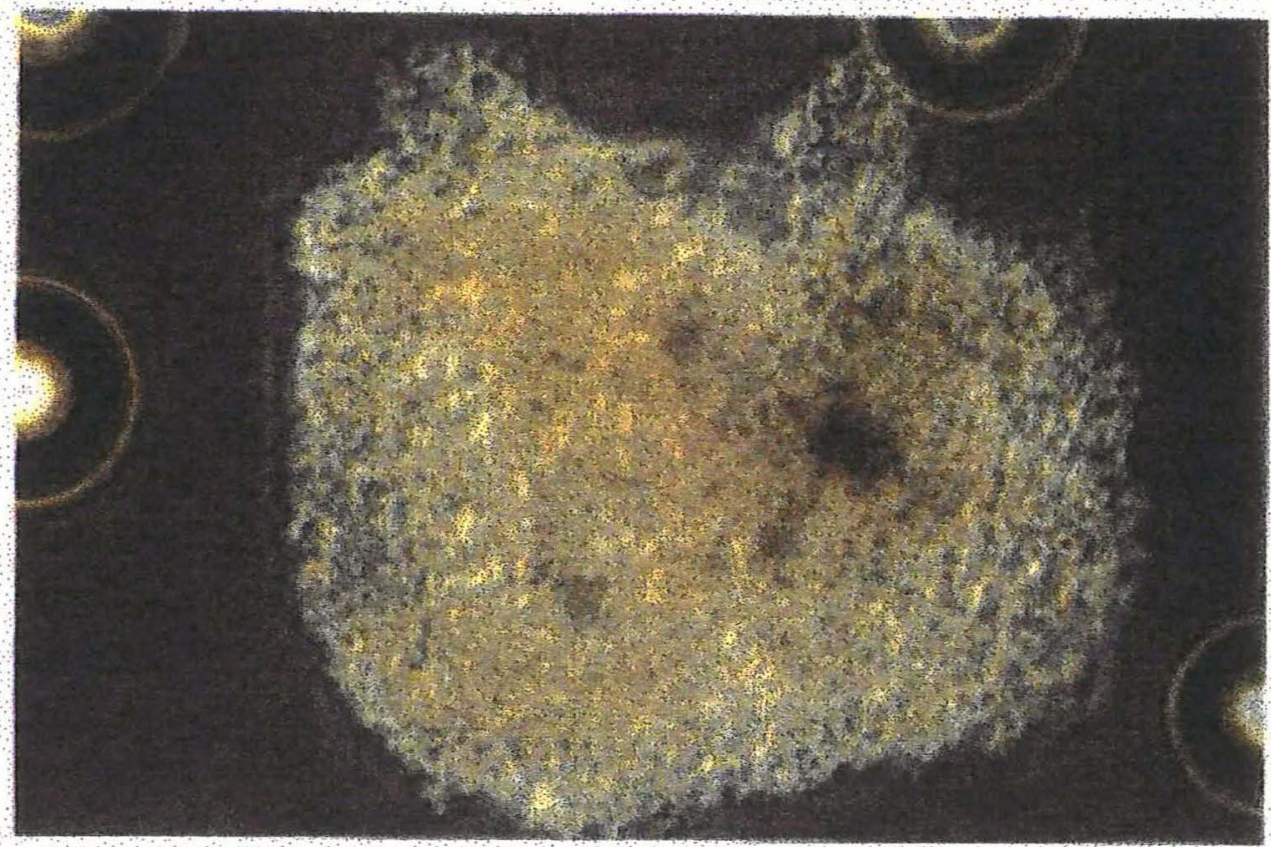

Figura 69 - Fotografia obtida por microscopia ótica de contraste de fase, mos trando uma pseudomorfose de microclínio em caulinita, na fração areia grossa do horizonte Bt2 do Perfil 10. 


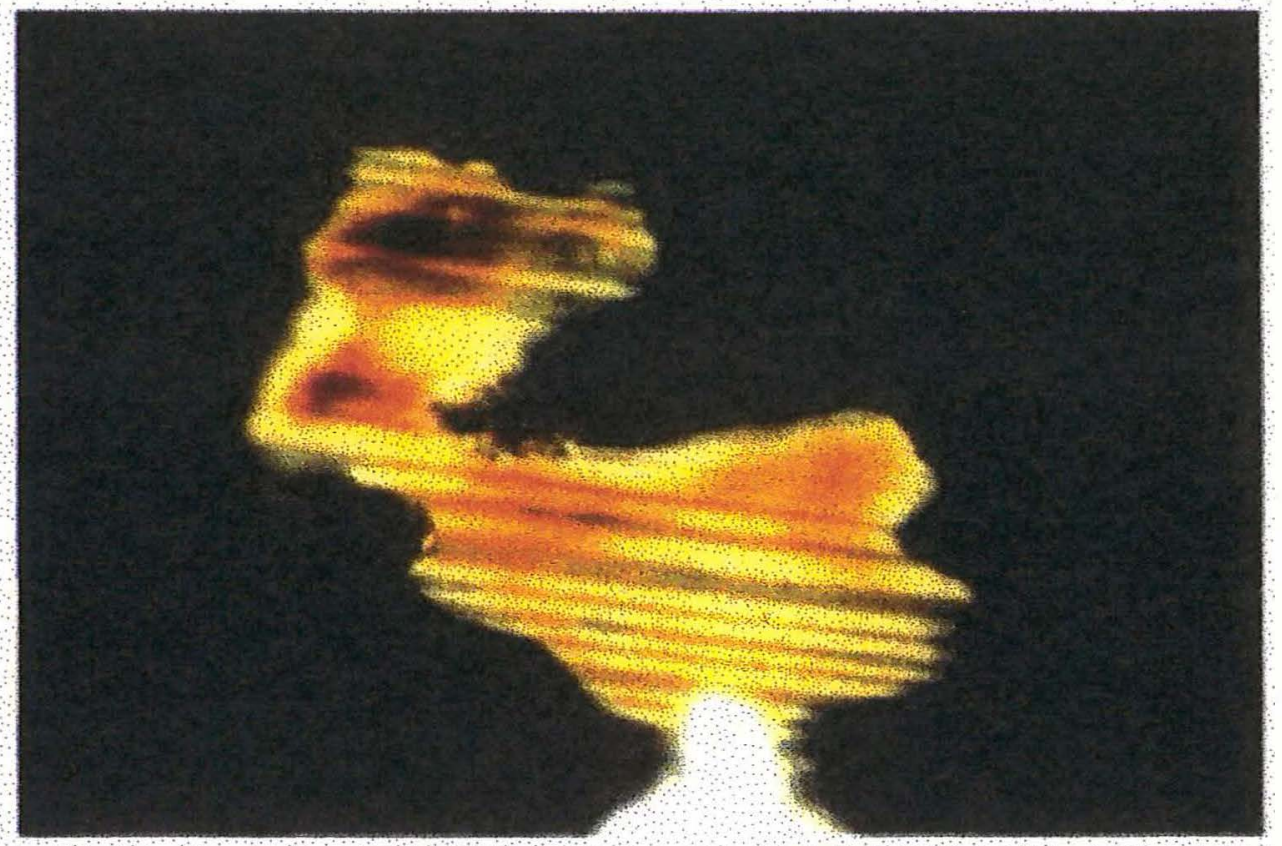

Figura 70 - Fotografia obtida por microscopia ótica de polarização, mostrando um feldspato ( albita ), praticamente inalterado, na fração areia fina no horizonte $2 \mathrm{CB}$ do perfil 11 (SS).

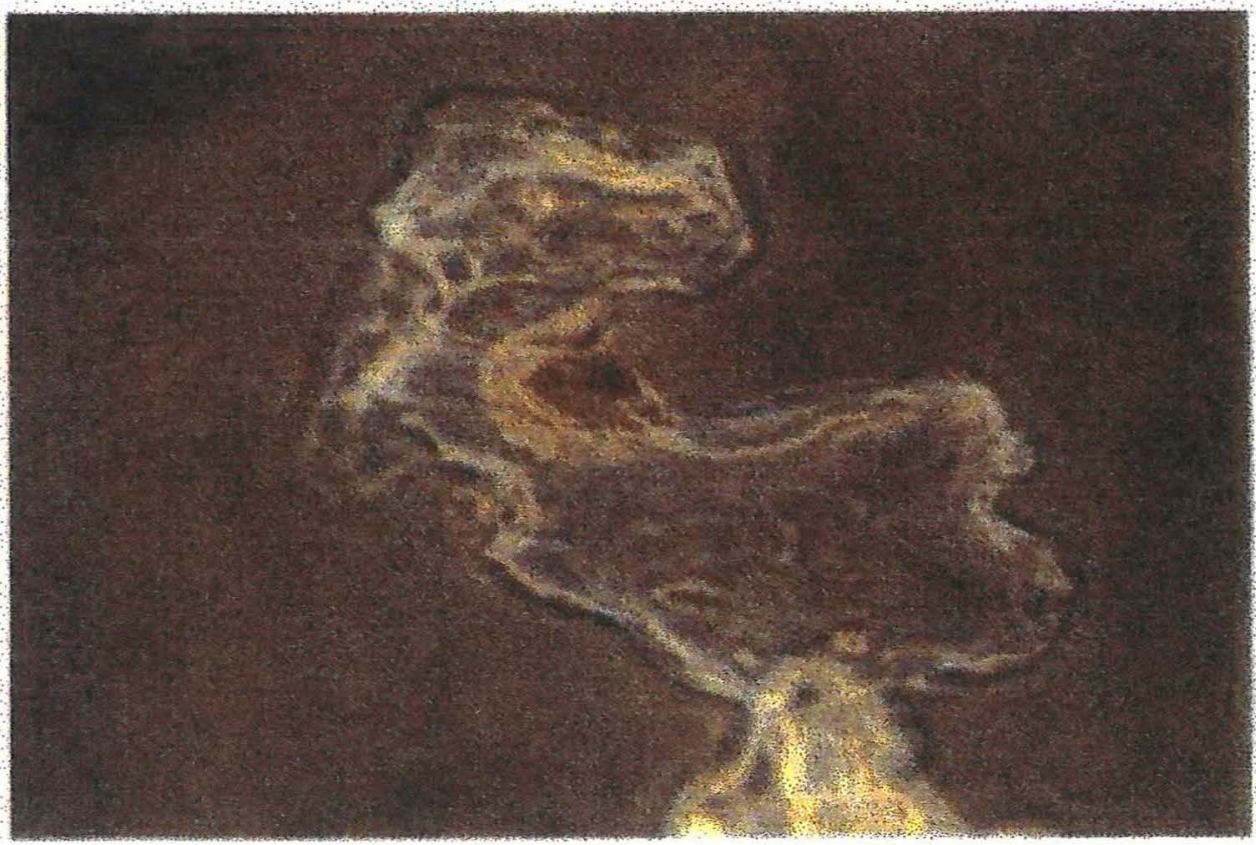

Figura 71 - Fotografia obtida por microscopia ótica de contraste de fase, mos trando uma pseudomorfose da albita para caulinita, na fração areia fina no horizonte $2 \mathrm{Btn}$ do perfil 11 (SS). 
No perfil 10 a presença de pseudomorfoses de feldspato e biotita para caulinita, são muito bem distinguidas. Nos horizontes inferiores deste perfil ( $\mathrm{BC}$ e $\mathrm{Cr}$ ), o feldspato predominante é a albita e nos mais superiores o microclínio. Em princípio, ambas as espécies de feldspatos na fração areia mais grossa, se alteram parcialmente em pseudomorfoses para caulinita. Os horizontes $\mathrm{BC}$ e $\mathrm{Cr}$, porém, em comparação com o $\mathrm{Bt}$, não indicam em valores quantitativos, quando se analisa os conteudos de feldspato, um enriquecimento pedogenético de argila nesse último.

De modo diferente, o comportamento da mica (biotita) pode ser comparado. Enquanto a soma dos teores de mica e pseudomorfoses de biotita para caulinita, na fração areia dos horizontes inferiores é de $268 \mathrm{~g} \mathrm{~kg}^{-1}$ (horizonte $\mathrm{Cr}$ ) e $318 \mathrm{~g} \mathrm{~kg}^{-1}$ (horizonte $\mathrm{BC}$ ), os seus teores são baixos no $\mathrm{Bt}$ $\left(22 \mathrm{~g} \mathrm{~kg}^{-1}\right)$. Portanto, o enriquecimento máximo de argila por volta de $339 \mathrm{~g}$ $\mathrm{kg}^{-1}$ no Bt2, é esclarecido em sua grande parte pela transformação da mica, já que a quantidade de argila nos horizontes $\mathrm{Cr}$ e $\mathrm{BC}$ (material originário), varia de $90 \mathrm{~g} \mathrm{~kg}^{-1}$ e $79 \mathrm{~g} \mathrm{~kg}^{-1}$ respectivamente. No horizonte Bt forma-se juntamente com a caulinita, pequenas quantidades de vermiculita.

A baixa quantidade de argila no horizonte $\mathrm{A}$, não é resultante de empobrecimento de argila (perda para o Bt por translocação), mas sim da deposição dessa partícula oriunda de processos de erosão vindos de fora. Os conteudos mais elevados de quartzo e feldspato também corroboram nitidamente com tal hipótese.

O perfil 11 (SS), tem na sua reserva mineral, juntamente com quartzo e caulinita, plagioclásios e biotita. Esse último aparece na fração argila como vermiculita. Diferentemente do perfil 10 (PVe), aqui o enriquecimento de 
argila no horizonte $2 \mathrm{Btn}$, pode ser deduzido pelas transformações da biotita e plagioclásios. $\mathrm{O}$ alto teor de $\mathrm{Na}^{+}$no $2 \mathrm{Btn}$ deve ser creditado à liberação desse cation, quando da decomposição da albita. No $2 \mathrm{CB}$ a quantidade total de plagioclásios é de $208 \mathrm{~g} \mathrm{~kg}^{-1}$ e o de biotita $256 \mathrm{~g} \mathrm{~kg}^{-1}$. No $2 \mathrm{Btn}$ essas quantidades baixam para $81 \mathrm{~g} \mathrm{~kg}^{-1}$ e $38 \mathrm{~g} \mathrm{~kg}^{-1}$ respectivamente, com uma diminuição total desses minerais de $345 \mathrm{~g} \mathrm{~kg}^{-1}$. A quantidade de argila (gênese de caulinita), aumenta de $272 \mathrm{~g} \mathrm{~kg}^{-1}$ do $2 \mathrm{CB}$ para o $2 \mathrm{Btn}$. Em torno de $38 \mathrm{~g} \mathrm{~kg}^{-1}$ no 2Btn, ainda persistem como pseudomorfoses de biotita para caulinita nas frações silte e areia e não mais existe vermiculita, possivelmente alterada para caulinita, na fração argila. Desse modo, também no perfil 11, o total de enriquecimento de argila, resulta preponderantemente de processos de transformação dos minerais descritos. As pequenas quantidades de argila nos horizontes A e E não são de origem pedogenética (translocação do A e E para o B), mais sim resultantes de transportes e deposições externas (origem pedimentar), condicionados por processos de erosão (vide os mais altos teores de quartzo e feldspato nesses horizontes do perfil - tabela 20).

As figuras 68 e 69 (perfil 10) e 70 e 71 (perfil 11), apresentam em fotomicrografias, processos de alterações de feldspatos em alguns horizontes dos dois pedons. Como já citado, no perfil 10 derivado de granito, os feldspatos surgem como microclínio e albita, ambos feldspatos alcalinos. Estes aparecem principalmente em partículas do tamanho da areia, sendo assim facilmente reconhecidos pelas suas propriedades óticas (refração luminosa e birrefrigência), como na laminação dupla (albita) e emaranhado 
duplo (microclínio). Também difratogramas de difração de raios $\mathrm{X}$ do pó desses minerais auxiliam a identificação.

A decomposição dos feldspatos nos solos citados, leva sempre à caulinitização ou seja ao enriquecimento em caulinita independente do regime hídrico (drenagem) do solo. As figuras 68 e 69 demonstram um microclínio praticamente inalterado e uma pseudomorfose de microclínio para caulinita, no horizonte Bt2 do perfil 10. Na figura 69 , a caulinitização abrange de forma visível todo o mineral ao longo do emaranhado e conduz à formação de agregados cauliníticos espalhados, que aparecem na cor escura sobre toda a superficie, bem como à separação do ácido silícico (manchas claras). O contínuo progresso da caulinitização, leva finalmente as pseudomorfoses a desintegrarem-se totalmente no tamanho do silte fino e argila, contribuindo dessa maneira, decisivamente para o enriquecimento de argila. As figuras 70 e 71 mostram a forma de alteração de uma albita (perfil 11). A transformação do mineral ocorre nesse caso de forma heterogênea (cavidades na superficie), possivelmente ao longo da laminação dupla e levando à caulinitização de outras áreas do mineral (figura 71). Resultados semelhantes foram observados por Aoudjit et al. (1995). A coesão das partículas de caulinita, surgidas nessas áreas (cavidades) é evidentemente diminuta, tanto que elas já se desintegram em silte fino ou argila, quando da análise granulométrica. A figura 70 apresenta a albita praticamente inalterada, com a sua estrutura primitiva ainda preservada (ver laminação dupla).

Decisivo para a decomposição dos feldspatos é notoriamente a sua estrutura e composição química. Albita e microclínio, encontrados 
preponderantemente nos perfis 10 e 11 , estão como sabemos entre os mais estáveis da família dos feldspatos (Goldich, 1938; Ahuja et al., 1993). Assim sendo, a maior parte das transformações mineralógicas e consequentemente a acumulação de argila no B textural (principalmente no perfil 10), deve ser creditado à decomposição de minerais menos estáveis (biotita). Os altos teores de sódio trocável no 2Btn do perfil 10, devem estar associados com a liberação desse ion quando da decomposição da albita com a sua permanência no solo sendo altamente favorecida pela drenagem deficiente do pedon.

\subsection{Interpretação dos resultados relacionados com a gênese, classificação e aptidão agrícola dos solos}

\subsubsection{Gênese}

Dez perfis de solos mencionados na tabela 1 e investigados na presente pesquisa apresentam horizonte $\mathrm{B}$ textural (argílico) ou nátrico (perfil 11). A grande maioria dos trabalhos até o momento existentes sobre a gênese e a composição mineralógica de solos de regiões semi-áridas, revelam um grau mínimo de decomposição no interior do solo em comparação ao material originário. A mineralogia da fração argila em tais solos em sua maioria de origem sedimentar, é dominada preponderantemente por argilo-minerais ilíticos e esmectíticos (Allen \& Fanning, 1983). 
Isso, evidentemente, não pode ser generalizado para os solos das regiões semi-áridas cearenses, derivados de rochas cristalinas por processos autóctones ou pseudo-autóctones.

As condições de semi-aridez do Nordeste do Brasil, ainda assim, mostram peculiaridades que diferem bastante de outras zonas semi-áridas do mundo (Ab’Saber, 1996).

A gênese do horizonte de acumulação de argila em ambientes semiáridos é especialmente duvidosa. Em muitos desses horizontes não ocorre a presença de cerosidade e em alguns solos onde tal feição existe, a mesma pode não está associada com a presença de iluviação, fatos esses que induzem a se duvidar da origem e importância essencial da iluviação na gênese do B textural. Também a hipótese da destruição da cerosidade nos horizontes que afloram próximo à superficie através de bioturbações e/ou fenômenos de contração e dilatação não estão bastante esclarecidos (Nettleton \& Peterson, 1983; Nettleton et al., 1969; Gebhardt, 1989; Isbell, 1980).

Os resultados obtidos no estudo ora em apreço, à luz da metodologia usada, mostram que a alteração de minerais primários "in situ”, presentes no material originário do solo, é essencialmente a fonte principal de enriquecimento de argila do horizonte B textural. Resultados semelhantes foram encontrados por Gebhardt, (1989); Koppi \& Williams, (1980); Alias \& Albaladejo, (1978); Isbell (1980); Nettleton \& Peterson, (1983).

As baixas quantidades de argila do horizonte $A$ ou do $A+E$, não estão associadas com perda por translocação para o Bt. A gênese desses horizontes superficiais é na maioria dos perfis estudados, de natureza 
pedimentar retrabalhados localmente. As figuras 72 a 76 apresentam a distribuição de quartzo com a profundidade nos perfis dentro das topossequências pesquisadas, com o objetivo de averiguar a uniformidade entre o material originário e o "solum" (Brewer, 1976). Analisando-se tais figuras, nota-se que nos perfis 1 e 2 (solos de Quixadá), os valores de quartzo diferem do(s) horizonte(s) superficiais para os mais inferiores em números bastante significativos. Assim no PVe os horizontes $2 \mathrm{Bt} 2$ e $2 \mathrm{BC}$ são autóctones, enquanto os demais ( $\mathrm{AB}, \mathrm{BA}$ e $\mathrm{Bt1}$ ), são provenientes de material transportado e retrabalhado localmente. No PL as diferenças entre os teores de quartzo dos horizontes superficiais e os mais profundos mostram altas disparidades, chegando a valores próximos de $100 \%$, entre Ap e E e $2 \mathrm{Cr} 2,2 \mathrm{Cr} 1$ e $2 \mathrm{BCn}$, indicando nesse caso também a ocorrência de um perfil pseudo-autóctone (figura 72). Embora o percentual de quartzo no horizonte $2 \mathrm{Btn}$, em relação àqueles presentes em $2 \mathrm{BCn}, 2 \mathrm{Cr} 1$ e $2 \mathrm{Cr} 2$ seja relativamente elevado, observações de campo levam à dedução de que o 2Btn também é originário do gnaisse subjacente. O teor mais elevado de quartzo nessa posição do perfil, provavelmente é proveniente de adição externa. Ademais, a ocorrência de uma linha de pedras separando o horizonte $\mathrm{E}$ do $2 \mathrm{Btn}$, corrobora para a natureza autóctone desse último (vide descrição morfológica, anexo A).

Nos solos de Canindé (figura 73), o perfil 5 mostra uma distribuição uniforme de quartzo com a profundidade, com a curva suavemente e quase totalmente paralela ao eixo dos " $\mathrm{x}$ ", sugerindo um perfil autóctone (Brewer, 1976). De maneira diferente os perfis 3 e 4, apresentam inflexão das curvas na posição do horizonte Bt. No perfil 3, a inflexão relativamente suave e as 
diferenças pequenas entre as percentagens de quartzo no horizonte $\mathrm{A}$ em relação a $\mathrm{R}, \mathrm{Cr}, \mathrm{Bt}$ e $\mathrm{BC}$, aliadas com a não existência no campo de linha de pedras, também são indicativos de um perfil autóctone. O perfil 4, por outro lado, mostra uma acentuada inflexão da curva ente o $\mathrm{A}$ e o $\mathrm{Bt}$, com características de que o horizonte superficial é proveniente de transporte e acúmulo de material ao longo da topossequência. A constatação de uma linha de cascalhos e calhaus de quartzo em sua maioria arredondados, nessa parte do perfil, conduz para uma hipótese de que o citado perfil tem natureza pseudo-autóctone.

Nos solos de Guaramiranga (figura 74), verifica-se nos perfis 6 e 7 duas situações bem diferentes. Enquanto no PVa a distibuição de quartzo com a profundidade está representada por uma curva praticamente paralela ao eixo dos " $\mathrm{x}$ " indicando homogeneidade do material originário e natureza autóctone do solo, no PEa uma forte inflexão da curva entre o horizonte $\mathrm{AB}$ e os demais do perfil, confere um aspecto nitidamente pseudo-autóctone a tal solo.

Os perfis 8,10 e 11 (figuras 75 e 76), apresentam curvas de distribuição de quartzo que sugerem de acordo com a inflexão das mesmas entre o horizonte superficial ( $\mathrm{A}$ ou $\mathrm{A}+\mathrm{E}$ ) e o Bt, um caráter também pseudo-autóctone para os três pedons. O exame macromorfológico desses perfis (anexo A), concordam com a hipótese supra citada, ao evidenciar a influência de material pedimentar retrabalhado na superficie. 

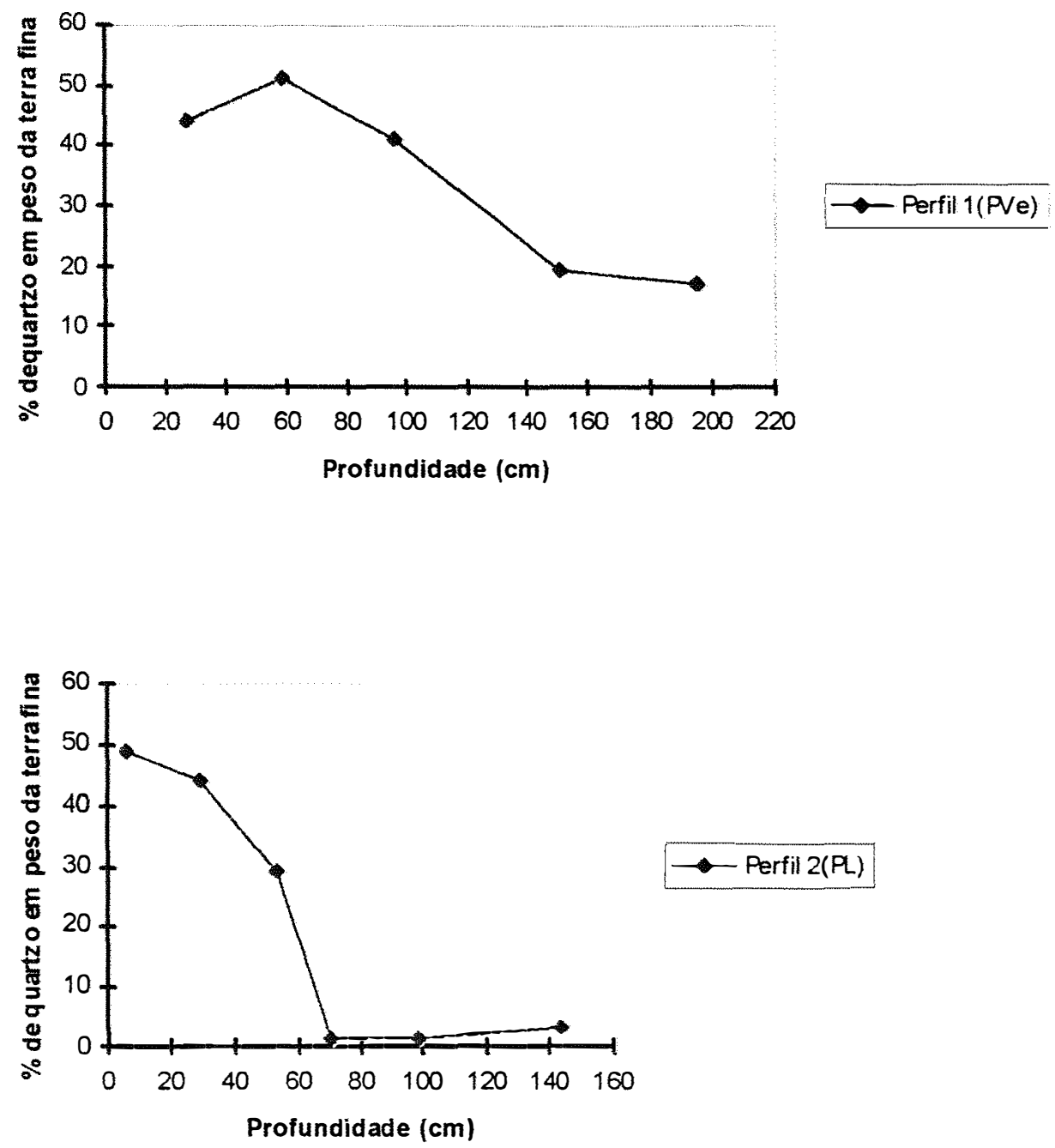

Figura 72 - Distribuição de quartzo com a profundida de nos perfis 1 e 2 . 

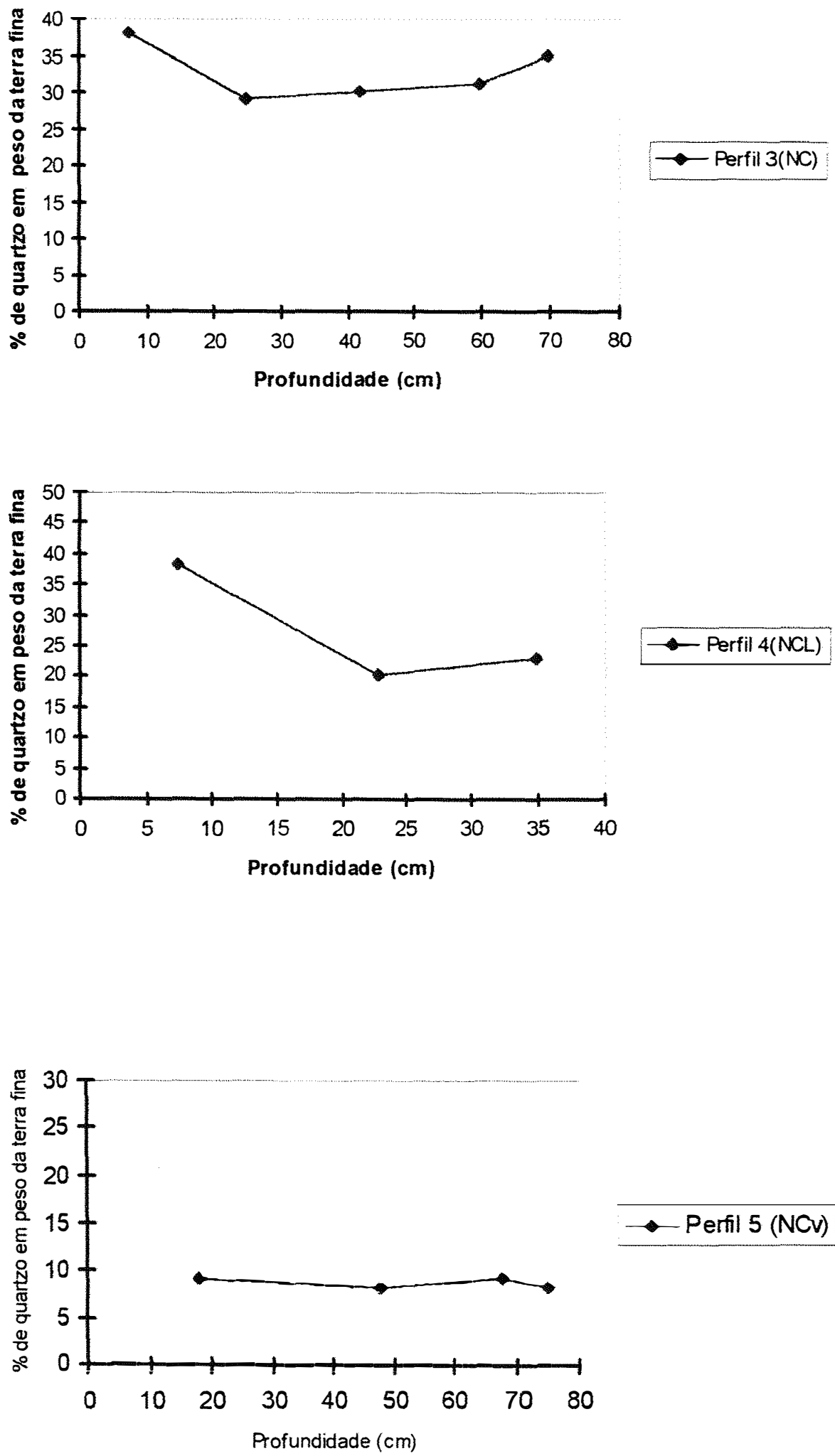

Perfil 5 (NCV)

Figura 73 - Distribuição de quartzo com a profun didade nos perfis 3,4 e 5 . 


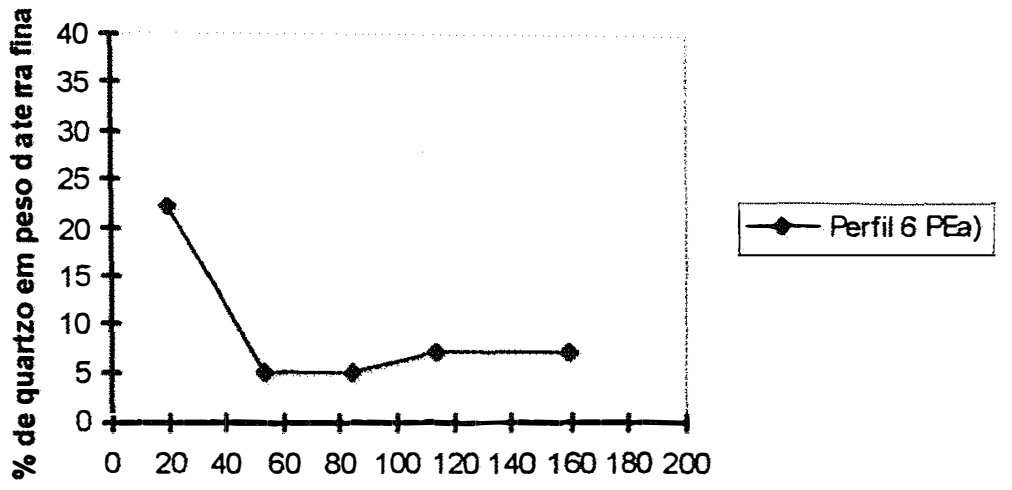

Profundidade $(\mathrm{cm})$

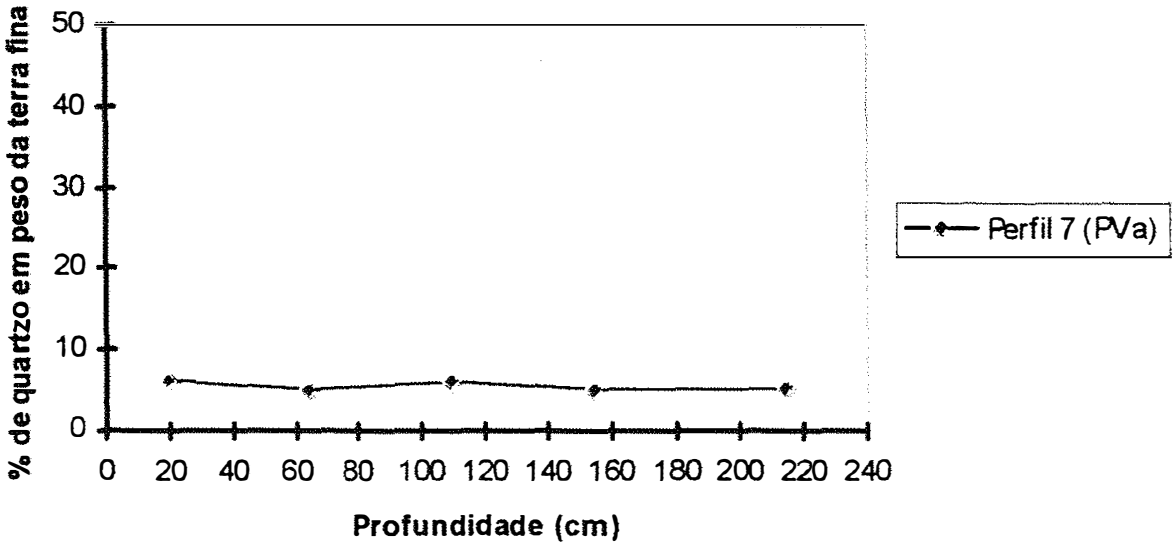

Figura 74 - Distribuição de quartzo com a profundi dade nos perfis 6 e 7 . 

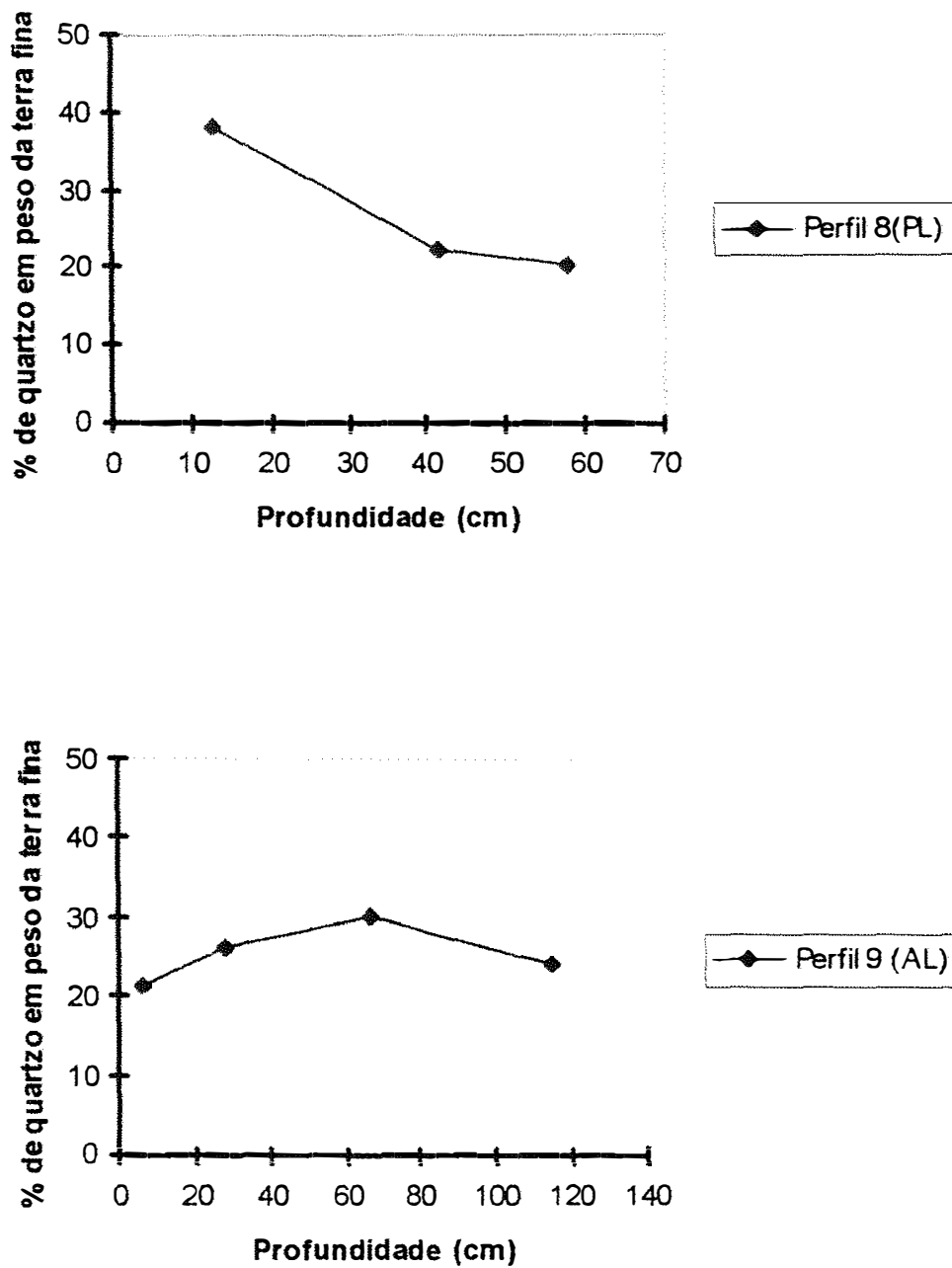

Figura 75 - Distribuição de quartzo com a profundidade nos perfis 8 e 9 . 

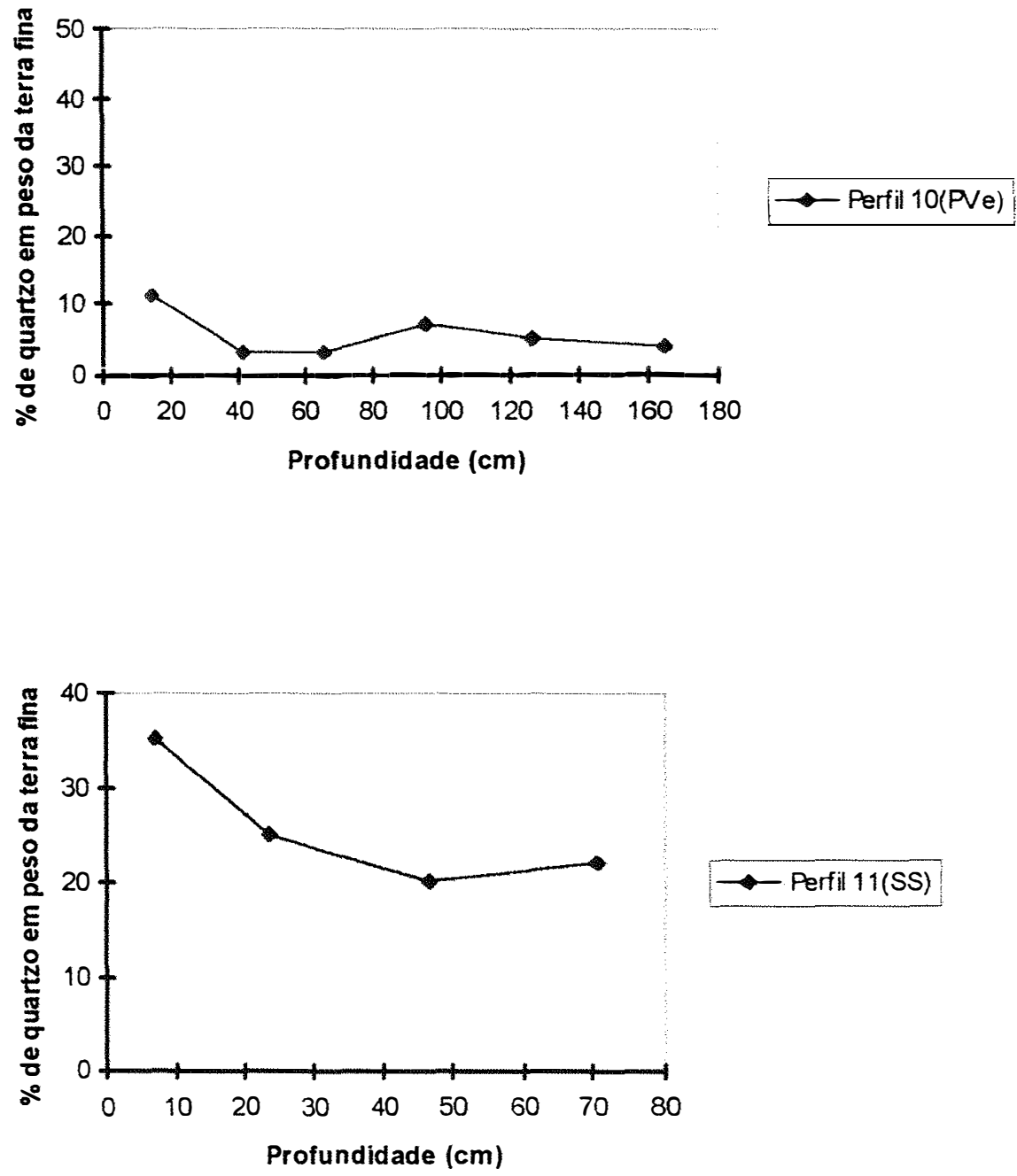

Figura 76 - Distribuição de quartzo com a profundidade nos perfis $10 \mathrm{e}$ 11. 


\subsubsection{Classificação dos solos}

De acordo com os resultados analíticos (físicos, químicos e mineralógicos) e as descrições morfológicas, os solos foram classificados em três sistemas taxonômicos: brasileiro (Brasil, 1973; Camargo et al., 1987 e Oliveira et al., 1992), americano (EUA, 1992) e FAO-UNESCO (Driessen \& Dudal, 1991). Os dois últimos têm características de universalidade (tabela 21).

Tabela 21. Classificação taxonômica dos perfis estudados.

\begin{tabular}{|c|c|c|c|}
\hline Perfil & Sistema brasileiro & Soil taxonomy & $\begin{array}{c}\text { FAO- } \\
\text { UNESCO }\end{array}$ \\
\hline $10(\mathrm{PVe})$ & $\begin{array}{l}\text { Podzólico Vermelho } \\
\text { Amarelo eutrófico Tb } \\
\text { A moderado textura } \\
\text { média cascalhenta }\end{array}$ & $\begin{array}{l}\text { Aridic Kanhaplustalfs, } \\
\text { franco argilo arenoso, } \\
\text { caulinítico, } \\
\text { isohipertérmico }\end{array}$ & Haplic Lixisols \\
\hline $1(\mathrm{PVe})$ & $\begin{array}{l}\text { Podzólico Vermelho } \\
\text { Amarelo eutrófico Tb } \\
\text { A fraco textura média }\end{array}$ & $\begin{array}{c}\text { Aridic Kandiustalfs, } \\
\text { franco argilo arenoso, } \\
\text { caulinítico, } \\
\text { isohipertérmico }\end{array}$ & Haplic Lixisols \\
\hline $6(\mathrm{PEa})$ & $\begin{array}{c}\text { Podzólico Vermelho } \\
\text { Escuro álico Tb A } \\
\text { moderado textura } \\
\text { média }\end{array}$ & $\begin{array}{c}\text { Rhodic } \\
\text { Kanhaplustults, franco } \\
\text { argiloso, caulinítico, } \\
\text { isohipertérmico }\end{array}$ & Haplic Acrisols \\
\hline 7 (PVa) & $\begin{array}{c}\text { Podzólico Vermelho } \\
\text { Amarelo álico plíntico } \\
\text { Tb A fraco textura } \\
\text { média }\end{array}$ & $\begin{array}{l}\text { Typic Kanhaplustults, } \\
\text { franco arenoso, } \\
\text { caulinítico, } \\
\text { isohipertérmico }\end{array}$ & Plintic Acrisols \\
\hline $3(\mathrm{NC})$ & $\begin{array}{c}\text { Bruno Não-Cálcico A } \\
\text { moderado textura } \\
\text { média }\end{array}$ & $\begin{array}{l}\text { Ustalfic Haplargids, } \\
\text { franco arenoso, } \\
\text { caulinítico } \\
\text { isohipertérmico }\end{array}$ & Haplic Luvisols \\
\hline
\end{tabular}


Tabela 21. Classificação taxonômica dos perfis estudados.

\begin{tabular}{|c|c|c|c|}
\hline 4(NCL) & $\begin{array}{l}\text { Bruno Não-Cálcico } \\
\text { Litólico A fraco } \\
\text { textura média/argilosa }\end{array}$ & $\begin{array}{l}\text { Lithic Haplargids, } \\
\text { argiloso, caulinítico, } \\
\text { isohipertérmico }\end{array}$ & Haplic Luvisols \\
\hline $5(\mathrm{NCv})$ & $\begin{array}{l}\text { Bruno Não-Cálcico } \\
\text { Vértico textura média }\end{array}$ & $\begin{array}{c}\text { Vertic Haplargids, } \\
\text { franco argilo arenoso, } \\
\text { caulinitico } \\
\text { isohipertérmico }\end{array}$ & Vertic Luvisols \\
\hline $8(\mathrm{PL})$ & $\begin{array}{c}\text { Planossolo Solódico } \\
\text { eutrófico Ta A fraco } \\
\text { textura } \\
\text { média/contrastante }\end{array}$ & $\begin{array}{c}\text { Typic Haplargids, } \\
\text { franco argilo arenoso, } \\
\text { montmorilonítico, } \\
\text { isohipertérmico }\end{array}$ & $\begin{array}{c}\text { Eutric } \\
\text { Planosols }\end{array}$ \\
\hline $2(\mathrm{PL})$ & $\begin{array}{c}\text { Planossolo Solódico } \\
\text { eutrófico Ta A fraco } \\
\text { textura arenosa } \\
\text { /argilosa }\end{array}$ & $\begin{array}{l}\text { Aridic Haplustalfs, } \\
\text { argiloso, "mixed" } \\
\text { isohipertérmico }\end{array}$ & $\begin{array}{c}\text { Eutric } \\
\text { Planosols }\end{array}$ \\
\hline $11(\mathrm{SS})$ & $\begin{array}{l}\text { Solonetz Solodizado } \\
\text { eutrófico } \mathrm{Tb} \text { abrupto A } \\
\text { moderado textura } \\
\text { arenosa/média }\end{array}$ & $\begin{array}{l}\text { Typic Natrustalfs, } \\
\text { franco argiloso, } \\
\text { caulinítico, } \\
\text { isohipertérmico }\end{array}$ & $\begin{array}{c}\text { Haplic } \\
\text { Solonetz }\end{array}$ \\
\hline
\end{tabular}

A classificação pelo sistema americano foi feita na categoria de família, considerando-se como seção de controle em todos os pedons o horizonte argílico. No sistema FAO-UNESCO a classificação foi realizada ao nível de unidade de solos. 


\subsubsection{Considerações sobre a aptidão agrícola dos solos}

A aptidão agrícola das classes de solos investigados, com exceção dos perfis 6 e 7, não localizados em ambiente semi-árido, é fortemente limitada pela falta de água, escassez de cursos d'água naturais permanentes, estação seca prolongada e as baixas e/ou irregulares precipitações pluviométricas (Brasil, 1973). Excetuando-se, também, os pedons de Guaramiranga, os demais perfis, todos eutróficos, são solos de alta fertilidade natural e a prática da irrigação convencional ou não, deve ser experimentada, pois sem esta, somente culturas muito resistentes à seca e/ou de ciclo muito curto, podem ser exploradas com algum sucesso. Os Planossolos Solódicos e o Solonetz Solodizado, também são solos com aptidão agrícola limitada, devido aos elevados teores de sódio trocável que apresentam. No entanto, os Planossolos com mais baixos teores $\mathrm{de} \mathrm{Na}^{+}$e situados em áreas de relevo plano, também podem ser usados com uma exploração agro-pastoril de culturas menos sensíveis ao sódio e que se adaptem a solos de drenagem deficiente. Por outro lado, pesquisas sobre nutrição mineral com diferentes culturas nesses solos, ainda são muito raras, para se predizer a sensibilidade das mesmas ao sódio trocável.

Os Brunos Não-Cálcicos de alta fertilidade natural e teores relativamente elevados de minerais meteorizáveis, além da escassez de água nas áreas onde ocorrem com mais frequência, mostram ainda como limitação a profundidade efetiva e a ocorrência frequente de pedregosidade superficial (pavimento desértico). Isso dificulta a mecanização, principalmente no Bruno Não-Cálcico Vértico, que tem condições físicas mais desfavoráveis, 
relacionadas com a sua mineralogia mais rica em mmerais 2:1 (montmorilonita).

Os Podzólicos Vermelho-Amarelos eutróficos, são os que demonstram uma aptidão agrícola mais intensiva no que se refere aos seus atributos físicos, químicos e mineralógicos. Como estão situados também em sua grande maioria em ambiente semi-árido, a estação seca prolongada proporciona uma escassez de água. Dependendo das condições de relevo, a agricultura irrigada parece ser a alternativa mais racional para a utilização dos mesmos com cultivos adaptados à região.

Os Podzólicos Vermelho-Amarelos ou Escuros álicos, têm como limitações básicas o relevo acidentado e o excesso de alumínio trocável nos dois perfis. As características hídricas nesses solos, mormente na vertente úmida, não são um fator limitante; razão porque, a aptidão agrícola para a horticultura e fruticultura tropical são boas alternativas para esses solos, desde que associadas com adubação e correção adequada da acidez .

\subsubsection{Considerações finais}

Embora os resultados obtidos e discutidos no trabalho em apreço, sejam bastante elucidativos da pouca contribuição do processo de iluviação na gênese do horizonte $B$ textural em todos os perfis investigados, pesquisas futuras nesses mesmos solos na área de micromorfologia são de grande importância de serem realizadas, com o propósito de trazer subsídios para esclarecer definitivamente a importância secundária da iluviação no enriquecimento de argila no $\mathrm{Bt}$, em solos derivados de rochas cristalinas no 
ambiente semi-árido cearense. Também pesquisas com outros minerais e/ou elementos estáveis tais como Zircônio e Titânio e o estabelecimento de suas relações com o quartzo, devem ser conduzidas para mais uma comprovação da natureza autóctone ou pseudo-autóctone dos perfis pesquisados. 


\section{CONCLUSÕES}

A discussão e interpretação dos resultados obtidos, à luz da metodologia empregada, conduziram às seguintes conclusões:

1. As condições de drenagem dos solos exerceram grande influência nas alterações dos minerais biotita e homblenda, os quais são transformados em caulinita ou vermiculita e montmorilonita em boas e imperfeitas condições de drenagem respectivamente.

2. A decomposição dos feldspatos nos solos pesquisados, conduziu quase sempre à formação de caulinita, independente da drenagem interna do solo.

3. O enriquecimento de argila no horizonte $\mathrm{B}$ textural $(\mathrm{Bt})$, em todos os perfis, ocorreu sugestivamente "in situ", a partir da transformação dos minerais primários presentes na rocha subjacente.

4. As diferenças mineralógicas nas frações areia, silte e argila nos perfis investigados, relacionam-se com os respectivos materiais de origem, drenagem interna e posição no relevo.

5. Os perfis 10 (PVe), 1 (PVe), 6 (PEa), 4 (NCL), 8 (PL), 2 (PL) e 11 (SS) são de natureza poligenética (pseudo-autóctones de origem pedimentar), enquanto que os perfis 7 (PVa), $3(\mathrm{NC})$ e $5(\mathrm{NCv})$ são 
autóctones, com base na distribuição do mineral quartzo com a profundidade e presença de linha de pedras no campo.

6. Os elevados teores de $\mathrm{Na}^{+}$nos perfis 11 (SS) e 8 e 2 (PL), são originados da liberação desse ion quando da decomposição da albita e plagioclásios ricos em sódio, com a drenagem deficiente desses solos favorecendo a permanência do sódio nos horizontes $\mathrm{B}$ e/ou $\mathrm{C}$ dos pedons.

7. De acordo com a mineralogia e demais atributos pedológicos o grau de evolução das classes de solos estudadas é o seguinte:

$$
\mathrm{PEa}>\mathrm{PVa}>\mathrm{PVe}>\mathrm{NC}>\mathrm{SS}>\mathrm{PL}
$$

8. Os perfis $6(\mathrm{PEa})$ e $7(\mathrm{PVa})$, localizados em ambiente sub-úmido não diferem significativamente em termos mineralógicos dos demais perfis, embora possam ser considerados os mais maturos dentro de uma análise global de atributos. 
ANEXO A 
PERFIL - 1

DATA: $19 / 11 / 92$

CLASSIFICAÇÃO: Podzólico Vermelho Amarelo eutrófico Tb A fraco textura média; Aridic Kandiustalfs, franco argilo arenoso, caulinítico, isohipertérmico(EUA,1992) ; Haplic Lixisols(FAO, 1991).

LOCALIZAÇÃO: Estado do Ceará, município de Quixadá, fazenda Lavoura Seca do CCA/UFC, $60 \mathrm{~m}$ à esquerda da casa de hóspedes.

SITUAÇÃO E DECLIVE: Perfil descrito em trincheira sob condições de vegetação natural, em terreno pouco inclinado( 3-8 \% de declive).

LITOLOGIA E FORMAÇÃO GEOLÓGICA: Pré-Cambriano Indiviso. Biotita-Gnaisse.

MATERIAL ORIGINÁRIO: Saprolito de gnaisse, com influência de material pedimentar retrabalhado até Btl.

PEDREGOSIDADE E ROCHOSIDADE: Ausência.

RELEVO - LOCAL - Plano.

REGIONAL - Suave ondulado.

EROSÃO: Laminar moderada a severa.

DRENAGEM: Bem drenado.

VEGETAÇÃO: Caatinga hiperxerófila.

USO ATUAL: Sem uso agrícola.

\section{DESCRIĊÃO DO PERFIL}

A - 0-12 cm; bruno avermelhado (5YR 4/3, úmido); areia franca; fraca pequena em blocos sub angulares; poros comuns pequenos e médios; friável, não plástico e não pegajoso; transição plana e clara.

$\mathrm{AB}$ - 12-43 cm; bruno avermelhado (5YR 4/4, úmido); franco arenoso; moderada média em blocos subangulares; poros pequenos e médios; friável, ligeiramente plástico e ligeiramente pegajoso; transição plana e clara.

BA - 43-74 cm; bruno avermelhado (5YR 4/4, úmido); franco arenoso; moderada média em blocos subangulares; poros comuns pequenos e médios; friável, ligeiramente plástico e ligeiramente pegajoso; transição plana e clara.

Bt1 - 74-119 cm; vermelho amarelado (5YR 4/6, úmido); franco argilo arenoso; forte média e grande em blocos angulares e subangulares; poros comuns e pequenos; muito duro, friável, plástico e pegajoso; transição plana e gradual.

2Bt2 - 119-185 cm; vermelho (2.5YR 4/8, úmido), vermelho (2.5YR 5/8, seco); mosqueado comum grande e distinto amarelo (10YR 7/8, seco); argila arenosa; forte média e grande em blocos angulares e subangulares; poros comuns e pequenos; cerosidade moderada e comum; muito duro, firme, plástico e pegajoso; transição plana e gradual.

2BC - 185-205 cm +; vermelho (2.5YR 4/8, úmido), vermelho (2.5YR 5/8, seco); mosqueado comum grande e distinto amarelo (10YR 7/8, seco); franco argilo arenoso; forte média e grande em blocos angulares e subangulares; poros comuns e pequenos; cerosidade moderada e comum; muito duro, firme, plástico e pegajoso.

RAIZES: Comuns pivotantes finas e médias em $\mathrm{A}$; comuns pivotantes e finas em $\mathrm{AB}$ e $\mathrm{BA}$; poucas pivotantes e finas em $\mathrm{Btl}, \mathrm{Bt} 2 \mathrm{e} \mathrm{BC}$.

EXAMINADORES: Francisco Ocian B. Mota e Harald Gebhardt.

OBSERVAÇÕES: a) intensa atividade biológica de cupins nos horizontes $A, A B, B A, B t 1$ e $\mathrm{Bt2}$; b) solo úmido até cerca de $80 \mathrm{~cm}$; c) não foi coletado material do horizonte $\mathrm{A}$, por o mesmo está muito perturbado. 
PERFIL - 2

DATA: $19 / 11 / 92$

CLASSIFICAÇÃO: Planossolo Solódico eutrófico Ta A fraco textura arenosa/argilosa cascalhenta;Aridic Haplustalfs, argiloso, mixed, isohipertérmico(EUA, 1992) ; Eutric Planosols(FAO, 1991).

LOCALIZAÇÃO: Estado do Ceará, município de Quixadá, fazenda Lavoura Seca do CCA/UFC, próximo à entrada da fazenda, lado esquerdo.

SITUAÇÃO E DECLIVE: Trincheira aberta em área plantada com feijão caupi, em terreno praticamente plano (0-3\% de declividade).

LITOLOGIA E FORMAÇÃO GEOLÓGICA: Pré-Cambriano Indiviso. Gnaisse.

MATERIAL ORIGINÁRIO: Saprolito de gnaisse com cobertura de material pedimentar.

RELEVO: LOCAL - Plano.

REGIONAL - Suave ondulado.

EROSÃO: Laminar ligeira.

DRENAGEM: Imperfeitamente drenado.

VEGETAÇÃO: Caatinga hiperxerófila.

USO ATUAL: Plantio de feijão caupi.

\section{DESCRICÃO DO PERFIL}

Ap - 0-15 cm; bruno (10YR 5/3, úmido); areia; grãos individuais; solto, não plástico e não pegajoso; transição plana e clara.

E - 15-45 cm; bruno amarelado escuro (10YR 4/4, /umido); areia franca; grãos individuais; solto, não plástico e não pegajoso; transição plana e abrupta.

2Btn - 45-63 cm; coloração variegada composta de bruno amarelado (10YR 5/4), bruno forte (7.5YR 5/8) e vermelho (2.5YR 4/8); argila arenosa cascalhenta; forte grande em blocos subangulares; extremamente duro, muito firme, muito plástico e muito pegajoso; transição irregular e clara.

2BCn - 63-79 cm; coloração variegada composta de bruno amarelado (10YR 5/4), bruno forte (7.5YR 5/8) e vermelho (2.5YR 4/8); areia franca cascalhenta; moderada média em blocos angulares e subangulares; duro, firme, plástico e pegajoso; transição irregular e abrupta.

$2 \mathrm{Crl}-79-118 \mathrm{~cm}$; rocha altamente intemperizada.

$2 \mathrm{Cr} 2-118-170 \mathrm{~cm}+$; rocha semi-intemperizada.

EXAMINADORES: Francisco Ocian Bastos Mota, Harald Gebhardt e Eisenhower Braga.

OBSERVAÇÕES: a) presença de linha de pedras entre E e 2Btn, constituida de cascalho e calhaus de quartzo predominantemente arredondados.

b) perfil úmido em Ap e E. 
PERFIL - 3

DATA: $26 / 11 / 92$

CLASSIFICAÇÃO: Bruno Não-Cálcico A moderado textura média; Ustalfic Haplargids, franco arenoso, caulinítico, isohipertérmico(EUA, 1992); Haplic Luvisols(FAO, 1991).

LOCALIZAÇÃO: Estado do Ceará, município de Canindé, estrada Canindé-Santa Quitéria. declividade.

SITUAÇÃO E DECLIVE: Trincheira aberta sob condições de vegetação natural com 3 a 8 \% de

LITOLOGIA E FORMAÇÃO GEOLÓGICA: Pré-Cambriano Indiviso. Biotita-Gnaisse.

MATERIAL ORIGINÁRIO: Saprolito de biotita-gnaisse.

RELEVO: LOCAL - Suave ondulado.

REGIONAL - Suave ondulado

EROSÃO: Laminar moderada.

DRENAGEM: Bem drenado.

VEGETAÇÃO: Caatinga hiperxerófila.

USO ATUAL: Sem uso agrícola.

\section{DESCRICÃO DO PERFIL}

A - 0-15 cm; bruno amarelado escuro (10YR 3/4, úmido), bruno amarelado escuro (10YR 4/4, seco); franco arenoso; moderada média em blocos angulares; ligeiramente duro, friável, ligeiramente plástico e ligeiramente pegajoso; transição irregular e clara.

Bt - 15-34 cm; bruno avermelhado escuro (5YR 3/3, úmido), bruno avermelhado escuro (5YR 3/4, seco); franco arenoso; moderada média em blocos angulares; duro, friável, plástico e pegajoso; transição irregular e abrupta.

BC - 34-50 cm; bruno avermelhado (5YR 4/4, úmido), vermelho amarelado (5YR 4/6, seco); franco arenoso; moderada média em blocos angulares; macio, friável, ligeiramente plástico e ligeiramente pegajoso; transição irregular e abrupta.

$\mathrm{Cr}$ - 50-70 cm ; rocha em estado avançado de intemperização.

$\mathrm{R}-70 \mathrm{~cm}+$.

EXAMINADORES: Francisco Ocian B. Mota e Harald Gebhardt. 
PERFIL - 4

DATA: $25 / 11 / 92$

CLASSIFICAÇÃO: Bruno Não-Cálcico Litólico A fraco textura média/argilosa; Lithic Haplargids, argiloso, caulinítico, isohipertérmico(EUA, 1992); Haplic Luvisols(FAO, 1991).

LOCALIZAÇÃO: Estado do Ceará, município de Canindé, estrada Canindé-Santa Quitéria.

SITUAÇÃO E DECLIVE: Perfil descrito em trincheira, sob condições de vegetação natural, com 8 a $15 \%$ de declividade.

LITOLOGIA E FORMAÇÃO GEOLÓGICA: Pré-Cambriano Indiviso. Biotita-Gnaisse.

MATERIAL ORIGINÁRIO: Saprolito de biotita-gnaisse, com influência de material pedimentar retrabalhado na superficie.

RELEVO: LOCAL - Suave ondulado.

REGIONAL - Suave ondulado.

EROSÃO: Laminar moderada

DRENAGEM: Bem drenado.

VEGETAÇÃO: Caatinga hiperxerófila.

USO ATUAL: Sem uso agrícola.

\section{DESCRICÃO DO PERFIL}

A - 0-15 cm; bruno amarelado escuro (10YR 3/4, úmido), bruno amarelado (10YR 5/4, seco); areia franca; moderada média em blocos subangulares; ligeiramente duro, friável, não plástico e ligeiramente pegajoso; transição irregular e clara.

Bt - 15-30 cm; vermelho amarelado (5YR 4/6, úmido), vermelho amarelado (5YR 5/6, seco); mosqueado comum médio e distinto vermelho (2.5YR 4/8, úmido); argila arenosa; moderada pequena e média em blocos angulares; duro, firme , plástico e pegajoso; transição plana e abrupta. com solo.

Cr - 30-40 cm; franco argilo arenoso; rocha em estado avançado de intemperização misturada

$\mathrm{R}-40 \mathrm{~cm}+$.

RAIZZS: Comuns finas e médias em A e poucas finas e médias em Bt.

EXAMINADORES: Francisco Ocian B. Mota e Harald Gebhardt. 
PERFIL - 5

DATA: $25 / 11 / 92$

CLASSIFICAÇÃO: Bruno Não-Cálcico Vértico textura média; Vertic Haplargids, franco argilo arenoso, caulinítico, isohipertérmico(EUA, 1992); Vertic Luvisols(FAO, 1991).

LOCALIZAÇÃO: Estado do Ceará, município de Canindé, estrada Canindé - Santa Quitéria.

SITUAÇÃO E DECLIVE: Perfil descrito em trincheira aberta no sopé da encosta, com 3-8 \% de declividade.

LITOLOGIA E FORMAÇÃO GEOLÓGICA: Pré- Cambriano Indiviso. Hornblenda-Gnaisse.

MATERIAL ORIGINÁRIO: Saprolito de hornblenda - gnaisse.

RELEVO: LOCAL -Suave ondulado

REGIONAL - Suave ondulado

EROSÃO: Laminar severa.

DRENAGEM: Moderadamente drenado.

VEGETAÇÃO: Caatinga hiperxerófila.

USO ATUAL: Sem uso agrícola.

\section{DESCRIĊ̃̃ODO PERFIL}

BA - 0-35 cm; bruno avermelhado escuro (2.5YR 3/4, úmido), bruno avermelhado escuro (2.5YR 3/4, seco); franco argilo arenoso; moderada média em blocos subangulares; ligeiramente duro, friável, ligeiramente plástico e ligeiramente pegajoso; transição irregular e clara.

$\mathrm{Bt}-35-60 \mathrm{~cm}$; vermelho escuro (2.5YR 3/6, úmido), vermelho escuro (2.5YR 3/6, seco); franco argilo arenoso; forte muito grande em blocos subangulares; slickenside muito e forte; muito duro, muito firme, plástico e pegajoso; transição irregular e clara.

BC - 60-75 cm; bruno avermelhado escuro (5YR 3/4, úmido), vermelho amarelado (5YR 4/6, seco); franco arenoso; fraca média em blocos subangulares; slickenside pouco e fraco; ligeiramente duro, friável, ligeiramente plástico e ligeiramente pegajoso; transição irregular e abrupta.

Cr $-75 \mathrm{~cm}+$; rocha em estado avançado de intemperização.

RAIZES: abundantes médias e finas em BA; comuns médias e finas em Bt e poucas e finas em BC.

EXAMINADORES: Francisco Ocian Bastos Mota e Harald Gebhardt.

OBS: a) Perfil parcialmente truncado;

b) Presença de rachaduras na superficie e no interior do perfil. 
PERFIL - 6

DATA: $22 / 11 / 92$

CLASSIFICAÇÃO: Podzólico Vermelho Escuro álico Tb A moderado textura média; Rhodic Kanhaplustults, franco argiloso, caulinítico, isohipertérmico(EUA, 1992); Haplic Acrisols(FAO,1991).

LOCALIZAÇÃO: Estado do Ceará, município de Guaramiranga, estrada BaturitéGuaramiranga, a $1 \mathrm{~km}$ do trevo que entra para Guaramiranga, lado esquerdo.

SITUAÇÃO E DECLIVE: Perfil descrito em trincheira sob condições de vegetação natural, em declive fortemente inclinado.

ALTITUDE: $900 \mathrm{~m}$ aproximadamente.

LITOLOGIA E FORMAÇÃO GEOLÓGICA: Pré-Cambriano Indiviso. Biotita-Muscovita Gnaisse.

MATERIAL ORIGINÁRIO: Saprolito de gnaisse, com influência de material retrabalhado na superficie

PEDREGOSIDADE E ROCHOSIDADE: Ausência.

RELEVO: LOCAL - Forte ondulado.

REGIONAL - Forte ondulado e montanhoso.

EROSÃO: Laminar severa.

DRENAGEM: Bem drenado.

VEGETAÇÃO: Floresta subperenifolia.

USO ATUAL: Sem uso agrícola.

\section{DESCRIĊÃO DO PERFIL}

$\mathrm{AB}-$ 0-40 cm; bruno escuro (7.5YR 4/2, úmido); franco argilo arenoso; moderada grande granular; muitos poros médios; friável, ligeiramente plástico e ligeiramente pegajoso; transição plana e clara.

2Btl - 40-70 cm; vermelho (2.5YR 4/6, úmido); franco argiloso; forte grande e média em blocos subangulares; poros comuns e pequenos; cerosidade moderada e comum; friável, plástico e pegajoso; transição plana e clara.

2Bt2 - 70-100 cm; vermelho (2.5YR 4/8, úmido); franco argiloso; forte média e grande em blocos subangulares; poros comuns e pequenos; cerosidade moderada e comum; friável, plástico e pegajoso; transição plana e clara.

2BC - 100-130 cm; vermelho (2.5YR 5/8, úmido); franco; moderada média em blocos subangulares; poros comuns e pequenos; friável, plástico e pegajoso; transição plana e clara.

2CB - 130-170 cm; bruno forte (7.5YR 5/8, úmido); franco arenoso; moderada média em blocos angulares; poros comuns e pequenos; friável, plástico e pegajoso; transição plana e clara.

2C - 170-190 cm +; amarelo brunado (10YR 6/6, úmido); franco arenoso; moderada média em blocos angulares; friável, ligeiramente plástico e ligeiramente pegajoso.

RAIZES: Abundantes fasciculadas e pivotantes finas e médias em $\mathrm{AB}$; poucas pivotantes e finas em 2Btl e 2Bt2.

EXAMINADORES: Francisco Ocian B. Mota e Harald Gebhardt.

OBSERVAÇÕES: a) perfil úmido.

b) perfil parcialmente truncado. 
PERFIL - 7

DATA:22/11/92

CLASSIFICAÇÃO: Podzólico Vermelho Amarelo álico Tb plíntico A fraco textura média; Typic Kanhaplustults, franco arenoso, caulinítico, isohipertérnico(EUA, 1992) ; Plintic Acrisols (FAO,1991).

LOCALIZAÇÃO: Estado do Ceará, municipio de Guaramiranga, estrada Forquilha-Campos Belos, transição vertente úmida - vertente seca a aproximadamente $8 \mathrm{~km}$ de Forquilha.

SITUAÇÃO E DECLIVE: Perfil descrito em uma trincheira, sob condições de vegetação natural em declive pouco inclinado.

ALTITUDE: $600 \mathrm{~m}$ aproximadamente. Gnaisse.

LITOLOGIA E FORMAÇÃO GEOLÓGICA: Pre-Cambriano Indiviso. Biotita-Muscovita

MATERIAL ORIGINÁRIO: saprolito de gnaisse.

PEDREGOSIDADE E ROCHOSIDADE: Ausência.

RELEVO: LOCAL - Forte ondulado.

REGIONAL - Forte ondulado e montanhoso.

EROSÃO: laminar severa.

DRENAGEM: moderadamente drenado.

VEGETAÇÃO: Transição floresta sub perenifólia-caatinga.

USO ATUAL: Sem uso agrícola.

\section{DESCRIC̃̃̃O DO PERFIL}

$\mathrm{AB}$ - 0-40 cm; amarelo brunado (10YR 6/6, úmido); franco arenoso; fraca média granular; muitos poros médios e grandes; friável, plástico e pegajoso; transição irregular e clara.

Btfl - 40-90 cm; coloração variegada composta de vermelho (10R 4/8) e bruno amarelado (10YR 5/8); franco arenoso; moderada média e grande em blocos subangulares; poros comuns e pequenos; cerosidade moderada e comum; friável, plástico e pegajoso; transição irregular e clara.

Btf2 - 90-130 cm; coloração variegada composta de vermelho (10R 4/8) e bruno amarelado (10YR 5/8); franco argilo arenoso; moderada média em blocos subangulares; poros comuns e pequenos; cerosidade moderada e comum; friável, plástico e pegajoso; transição abrupta e irregular.

CB - 130-180 cm; coloração variegada composta de vermelho (10R 4/8) e bruno amarelado (10YR 5/8); franco arenoso muito cascalhento; moderada média em blocos subangulares; duro, firme , plástico e pegajoso; transição irregular e difusa.

Cr - 180-250 cm +; rocha em estado avançado de intemperização.

RAIZES: Muitas fasciculadas e pivotantes médias e finas em $\mathrm{AB}$; poucas pivotantes e finas em Btfl e Btf2; raras pivotantes e médias em $\mathrm{CB}$ e $\mathrm{C}$.

EXAMINADORES: Francisco Ocian B. Mota e Harald Gebhardt.

OBSERVAÇÕES:a) Perfil úmido até Btf2;

b) Perfil parcialmente truncado. 
PERFIL - 08

DATA: $02 / 12 / 92$

CLASSIFICAÇÃO: Planossolo Solódico eutrófico Ta A fraco textura média/contrastante; Typic Haplargids, franco argilo arenoso, montmorilonítico, isohipertérmico(EUA, 1992) ; Eutric Planosols(FAO, 1991). casa sede.

LOCALIZAÇÃO: Estado do Ceará, município de Tauá, fazenda Várzea da Serra, próximo à

SITUAÇÃO E DECLIVE: Trincheira aberta sob condições de vegetação natural, com 0 a $3 \%$ de declive

LITOLOGIA E FORMAÇÃO GEOLÓGICA: Pre-Cambriano Indiviso. Gnaisse.

MATERIAL ORIGINÁRIO: Saprolito de gnaisse, com cobertura de material podimentar.

RELEVO: LOCAL - Plano.

REGIONAL - Suave ondulado.

EROSÃO: Laminar ligeira.

DRENAGEM: Imperfeitamente drenado.

VEGETAÇÃO: Caatinga hiperxerófila.

USO ATUAL: Sem uso agrícola.

\section{DESCRICÃO DO PERFIL}

A - 0-25 cm; bruno escuro (7.5YR 3/4, úmido), bruno (7.5YR 4/4, seco); mosqueado pouco médio e difuso bruno amarelado (10YR 5/6, seco); franco arenoso; composta de grãos simples e moderada média em blocos angulares; ligeiramente duro, friável, não plástico e ligeiramente pegajoso; transição irregular e abrupta.

2Btn - 25-58 cm; bruno escuro (10YR 4/3, úmido), bruno (10YR 5/3,seco); mosqueado comum grande e distinto bruno amarelado (10YR 5/6, seco); franco argilo arenoso cascalhento; forte muito grande prismática; extremamente duro, extremamente firme, muito plástico e muito pegajoso; transição irregular e abrupta.

$2 \mathrm{Cr}-58 \mathrm{~cm}+$; rocha em estado avançado de intemperização misturada com solo.

RAIZES: Poucas e finas em A.

EXAMINADORES: Francisco Ocian Bastos Mota e Harald Gebhardt. 
PERFIL - 10

DATA: $12 / 11 / 92$

CLASSIFICAÇÃO: Podzólico Vermelho Amarelo eutrófico Tb A moderado textura média cascalhenta; Aridic Kanhaplustalfs, franco argilo arenoso, caulinítico, isohipertérmico(EUA, 1992) ; Haplic Lixisols(FAO, 1991).

LOCALIZAÇÃO: Estado do Ceará, município de Itapagé, no km 120 da BR 222, lado direito da estrada na direção de Sobral. declividade.

SITUAÇÃO E DECLIVE: Perfil descrito em trincheira, sob vegetação natural, com 3 a $8 \%$ de

LITOLOGIA E FORMAÇÃO GEOLÓGICA: Pré-Cambriano Indiviso. Granito.

MATERIAL ORIGINÁRIO: Saprolito proveniente da decomposição do granito, com influência de material retrabalhado na superficie.

RELEVO: LOCAL - Plano.

REGIONAL - Suave ondulado a ondulado.

EROSÃO: Laminar ligeira.

DRENAGEM: Bem drenado.

VEGETAÇÃO: Caatinga hiperxerófila.

USO ATUAL: Sem uso agrícola.

\section{DESCRIĊÃO DO PERFIL}

A - 0-30 cm; bruno escuro (7.5YR 3/4, úmido), bruno (7.5YR 5/4, seco); franco argilo arenoso cascalhento; moderada média em blocos angulares; duro, friável, plástico e pegajoso; transição plana e clara.

Btl - 30-53 cm; vermelho amarelado (5YR 4/6, úmido), vermelho amarelado (5YR 4/6, seco); franco argilo arenoso cascalhento; moderada grande em blocos subangulares; cerosidade moderada $\mathrm{e}$ comum; duro, friável, plástico e pegajoso; transição plana e clara.

Bt2 - 53-79 cm; vermelho (2.5YR 4/8, úmido), vermelho (2.5YR 5/6, seco); franco argilo arenoso cascalhento; moderada grande em blocos subangulares; cerosidade moderada e comum; duro, friável, plástico e pegajoso; transição plana e clara.

Bt3 - 79-1 $13 \mathrm{~cm}$; vermelho amarelado (5YR 4/6, úmido), vermelho amarelado (5YR 4/6, seco); franco argilo arenoso cascalhento; moderada grande em blocos subangulares; duro, friável, plástico e pegajoso; transição plana e clara.

BC - 113-140 cm; vermelho amarelado (5YR 5/6, úmido), vermelho amarelado (5YR 5/8, seco); areia franca muito cascalhento; fraca média em blocos subangulares; ligeiramente duro, friável, ligeiramente plástico e ligeiramente pegajoso; transição plana e clara.

Cr - 140-190 cm; rocha em estado avançado de intemperização + solo muito cascalhento.

$\mathrm{R}-190 \mathrm{~cm}+$.

EXAMINADORES: Francisco Ocian B. Mota e Harald Gebhardt. 
PERFIL - 11

DATA: $11 / 12 / 92$

CLASSIFICAÇÃO: Solonetz-Solodizado eutrófico Tb abrupto A moderado textura arenosa/ média; Typic Natrustalfs, franco argiloso, caulinítico, isohipertérmico(EUA, 1992); Haplic Solonetz(FAO, 1991).

LOCALIZAÇÃO: Estado do Ceará, município de São Gonçalo do Amarante, km 55 da BR 222, lado direito da estrada, na direção Fortaleza-Sobral.

SITUAÇÃO E DECLIVE: Perfil descrito em trincheira sob condições de vegetação natural com $0-3 \%$ de declividade.

FORMAÇÃO GEOLÓGICA E LITOLOGIA: Pré-Cambriano Indiviso. Gnaisse.

MATERIAL ORIGINÁRIO: Saprolito de gnaisse, com cobertura de material pedimentar.

RELEVO: LOCAL - Plano.

REGIONAL - Suave ondulado.

DRENAGEM: Imperfeitamente a moderadamente drenado.

EROSÃO: Laminar moderada.

VEGETAÇÃO: Caatinga hiperxerófila.

USO ATUAL: Sem uso agrícola.

\section{DESCRIČÃO DO PERFIL}

A - 0-15 cm; bruno escuro (10YR 4/3, úmido), bruno claro acinzentado (10YR 6/3, seco); mosqueado comum médio e distinto bruno forte ( $7.5 \mathrm{YR}$ 5/8, úmido); franco arenoso; composta de grãos individuais e fraca pequena e média granular; macio, muito friável, não plástico e não pegajoso; transição plana e abrupta.

E - 15-32 cm; bruno acinzentado (10YR 5/2, úmido), cinzento claro (10YR 7/2, seco); mosqueado pouco médio e distinto bruno forte (7.5YR 5/8, úmido); franco; composta de grãos individuais e fraca paquena e média granular; macio, muito friável, não plástico e não pegajoso; transição plana e abrupta.

2Btn - 32-62 cm; bruno escuro (10YR 4/3, úmido), cinzento brunado claro (10YR 6/2, seco); mosqueado comum médio e distinto bruno forte (7.5YR 5/8, úmido); franco argiloso; forte grande colunar; extremamente duro, extremamente firme, plástico e pegajoso.

2CB - $62-80 \mathrm{~cm}+$; rocha em estado avançado de intemperização misturada com solo.

RAIZES: Comuns finas e médias em A e E e poucas finas e médias em 2Btn.

EXAMINADORES: Francisco Ocian Bastos Mota e Harald Gebhardt.

OBS: Presença entre os horizontes E e 2Btn de uma linha descontínua de calhaus arredondados e angulosos de quarto. 
ANEXO B 
PERFIL - 9

Data: $02 / 12 / 92$

CLASSIFICAÇÃO: Solo Aluvial eutrófico sódico A fraco textura média; Vertic torrifluvents (EUA, 1992);

LOCALIZAÇÃO: Estado do Ceará, município de Tauá, fazenda Várzea da Serra, no plantio de arroz.

SITUAÇÃO E DECLIVE: Trincheira aberta sob condições de plantio de arroz, em terreno praticamente plano ( $0-3 \%$ de declividade).

MATERIAL ORIGINÁRIO: Sedimentos referidos ao holoceno.

RELEVO: LOCAL - plano.

REGIONAL - Suave ondulado.

EROSÃO: Laminar ligeira.

DRENAGEM: Imperfeitamente drenado.

VEGETAÇÃO: LOCAL - Juazeiro, jurema preta, bamburral e velame.

REGIONAL - Caatinga hiperxerófila.

\section{DESCRICÃO DO PERFIL}

Ap - 0 -14; bruno escuro (10YR 4/3, úmido), bruno claro acinzentado (10YR 6/3, seco); franco; forte média em blocos subangulares; muito duro, muito firme, plástico e pegajoso; transição plana e abrupta.

$2 \mathrm{Cl}$ - 14 - 44; vermelho acinzentado (2.5YR 4/2, úmido), vermelho acinzentado (2.5YR 5/2, seco); mosqueado pouco médio distinto amarelo (10YR 7/8, seco); franco arenoso; forte grande prismática; muito duro, muito firme, plástico e pegajoso; transição plana e clara.

2C2 - 44 - 89; bruno acinzentado escuro (2.5YR 4/2, úmido), bruno acinzentado (2.5YR 5/2, seco); franco arenoso; forte grande prismática; muito duro, muito firme, plástico e pegajoso; transição plana e clara.

3C - 89 - 140 +; bruno acinzentado escuro (10YR 4/2, úmido), bruno (10YR 5/3, seco); mosqueado abundante grande distinto amarelo (10YR 7/8, seco); franco argilo arenoso; forte média em blocos angulares; muito duro, muito firme, plástico e pegajoso.

RALZES: poucas finas e médias em Ap e 2C1; raras finas e médias em $2 \mathrm{C} 2$ e $3 \mathrm{C}$.

EXAMINADORES: Francisco Ocian B. Mota e Harald Gebhardt.

OBSERVAÇÕES: Presença de fendas na superfície e interior do perfil. 
Tabela 22. Alguns atributos fisicos do perfil 9 ( Solo Aluvial ).

\begin{tabular}{|c|c|c|c|c|c|c|c|}
\hline \multirow[t]{2}{*}{ Horizonte } & \multirow[t]{2}{*}{$\begin{array}{l}\text { Prof. } \\
(\mathrm{cm})\end{array}$} & \multicolumn{4}{|c|}{ Análise Granulométrica $\left(\mathrm{g} \mathrm{kg}^{-1}\right)$} & \multirow[t]{2}{*}{ Classe Textural } & \multirow[t]{2}{*}{$\begin{array}{c}\text { Relação } \\
\text { silte/argila }\end{array}$} \\
\hline & & A. Grossa & A. Fina & Silte & Argila & & \\
\hline Ap & $0-14$ & 150 & 360 & 360 & 130 & Franco & 2,8 \\
\hline $2 \mathrm{Cl}$ & $14-44$ & 290 & 400 & 130 & 180 & Fr. arenoso & 0,7 \\
\hline $2 \mathrm{C} 2$ & $44-89$ & 370 & 310 & 130 & 190 & Fr. arenoso & 0,7 \\
\hline $3 \mathrm{C}$ & $89-140+$ & 190 & 300 & 260 & 250 & Fr. Arg. arenoso & 1,0 \\
\hline
\end{tabular}

Tabela 23. Alguns atributos químicos do perfil 9 ( Solo Aluvial).

\begin{tabular}{|c|c|c|c|c|c|c|c|c|c|}
\hline Horizon & $\begin{array}{l}\text { Prof. } \\
\text { (cm) }\end{array}$ & $\begin{array}{c}\mathrm{C} \\
\mathrm{g} \mathrm{kg}^{-1}\end{array}$ & $\begin{array}{c}\mathrm{CE} \\
\mathrm{dS} \mathrm{m}^{-1}\end{array}$ & $\begin{array}{c}\mathrm{pH} \\
\left(\mathrm{H}_{2} \mathrm{O}\right)\end{array}$ & $\begin{array}{c}\mathrm{N} \\
\mathrm{g} \mathrm{kg}^{-1}\end{array}$ & $\mathrm{C} / \mathrm{N}$ & $\begin{array}{l}\text { M.O } \\
\mathrm{g} \mathrm{kg}^{-1}\end{array}$ & $\begin{array}{c}\mathrm{P} \\
\mathrm{mg} \mathrm{kg}^{-1}\end{array}$ & $\begin{array}{l}\text { Fed Ald } \\
\mathrm{g} \mathrm{kg}^{-1}\end{array}$ \\
\hline Ap & $0-14$ & 8,9 & 0,4 & 6,4 & 0,7 & 12 & 15,3 & 14,1 & $2,4 \quad 1,3$ \\
\hline $2 \mathrm{C} 1$ & $14-44$ & 0,4 & 9,9 & 7,8 & 0,1 & 4 & 0,7 & 6,5 & $\begin{array}{ll}2,6 & 1,8\end{array}$ \\
\hline $2 \mathrm{C} 2$ & $44-89$ & 0,5 & 1,6 & 8,3 & 0,1 & 3 & 0,9 & 1,3 & $0,8 \quad 1,2$ \\
\hline $3 C$ & $89-140$ & 2,0 & 0,8 & 7,9 & 0,2 & 10 & 3,4 & 13,6 & $2,5 \quad 1,9$ \\
\hline
\end{tabular}

Tabela 24. Complexo sortivo do perfil 9 ( Solo Aluvial).

\begin{tabular}{|c|c|c|c|c|c|c|c|c|c|}
\hline \multirow[t]{2}{*}{ Horizonte } & \multirow[t]{2}{*}{$\begin{array}{l}\text { Prof. } \\
(\mathrm{cm})\end{array}$} & \multicolumn{6}{|c|}{$\begin{array}{l}\text { Complexo Sortivo } \\
\mathrm{cmol}(+) \mathrm{kg}^{-1} \text { de solo }\end{array}$} & \multirow[t]{2}{*}{$\begin{array}{l}\mathrm{Na}^{+} \\
\%\end{array}$} & \multirow[t]{2}{*}{$\begin{array}{l}\mathrm{V} \\
\%\end{array}$} \\
\hline & & $\mathrm{Ca}$ & $\mathrm{Mg}$ & $\mathrm{K}$ & $\mathrm{Na}$ & $\mathrm{H}+\mathrm{Al}$ & $\mathrm{T}$ & & \\
\hline Ap & $0-14$ & 5,3 & 1,5 & 0,3 & 0,2 & 1,1 & $7,3 \quad 8,4$ & 2,9 & 87 \\
\hline $2 \mathrm{C} 1$ & $14-44$ & 3,6 & 1,3 & 0,1 & 4,9 & 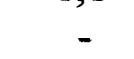 & $9,99,9$ & 49,8 & 100 \\
\hline $2 \mathrm{C} 2$ & $44-89$ & 4,8 & 1,7 & 0,1 & 4,2 & - & $10,8 \quad 10,8$ & 38,9 & 100 \\
\hline $3 \mathrm{C}$ & $89-140$ & 5,5 & 2,7 & 0,1 & 4,2 & - & $12,5 \quad 12,5$ & 33,6 & 100 \\
\hline
\end{tabular}


Tabela 25. Mineralogia do perfil 9 ( $\mathrm{Al}$ ), em $\%$ de peso da terra fina $<2 \mathrm{~mm}\left(\mathrm{~g} \mathrm{~kg}^{-1}\right)$.

Tamanho da fração $(\mu \mathrm{m})$

Horz. Tipo de Mineral $>200 \quad 200-53 \quad 53-20 \quad 20-2 \quad<2 \quad \Sigma$

\begin{tabular}{|c|c|c|c|c|c|c|c|}
\hline \multirow{8}{*}{ Ap } & Quartzo & 151 & 211 & 31 & 66 & 6 & 465 \\
\hline & Plagioclásio & 14 & 100 & 17 & 67 & 6 & 204 \\
\hline & Biotita $^{2}$ & 4 & 17 & 3 & 19 & - & 43 \\
\hline & Hornblenda $^{3}$ & 9 & 35 & 6 & 9 & - & 59 \\
\hline & Esmectita & - & - & - & 8 & 12 & 20 \\
\hline & Caulinita & - & - & - & 9 & 58 & 67 \\
\hline & Vermiculita & - & $=$ & - & - & 36 & 36 \\
\hline & & 178 & $\Sigma$ & 57 & 178 & 118 & $894^{4}$ \\
\hline \multirow{8}{*}{$2 \mathrm{Cl}$} & Quarzzo & 185 & 264 & 19 & 60 & 8 & 536 \\
\hline & Plagioclásio & 22 & 88 & 6 & 45 & 7 & 168 \\
\hline & Biotita & - & - & - & 15 & - & 15 \\
\hline & Hornblenda & 11 & 48 & 4 & 7 & - & 70 \\
\hline & Esmectita & - & - & - & 8 & 57 & 65 \\
\hline & Caulinita & - & - & - & 8 & 74 & 82 \\
\hline & Vermiculita & - & - & - & - & 8 & 8 \\
\hline & $\Sigma$ & 218 & 400 & 29 & 143 & 154 & 944 \\
\hline \multirow{8}{*}{$2 \mathrm{C} 2$} & Quartzo & 303 & 231 & 12 & 31 & 5 & 582 \\
\hline & Plagioclásio & 59 & 88 & 4 & 27 & 5 & 183 \\
\hline & Biotita & - & - & 2 & 6 & - & 8 \\
\hline & Hornblenda & 4 & 28 & 1 & 11 & - & 44 \\
\hline & Esmectita & - & - & - & 22 & 56 & 78 \\
\hline & Caulinita & - & - & - & 11 & 64 & 75 \\
\hline & Vermiculita & - & - & - & - & 19 & 19 \\
\hline & $\Sigma$ & 366 & 347 & 19 & 108 & 149 & 989 \\
\hline \multirow{8}{*}{$3 C$} & Quartzo & 170 & 244 & 23 & 61 & 12 & 510 \\
\hline & Plagioclásio & 39 & 59 & 10 & 60 & 11 & 179 \\
\hline & Biotita & - & 2 & 2 & 5 & - & 9 \\
\hline & Hornblenda & 3 & 23 & 3 & 16 & - & 45 \\
\hline & Esmectita & - & - & - & 8 & 108 & 116 \\
\hline & Caulinita & - & - & - & 7 & 84 & 91 \\
\hline & Vermiculita & - & - & - & - & 24 & 24 \\
\hline & $\Sigma$ & 212 & 328 & 38 & 157 & 239 & 974 \\
\hline
\end{tabular}

1) Predominantemente albita;

2)Flogopita-biotita nas frações areia e silte;

3) $\mathrm{Na}$ areia fina e silte grosso pseudomorfose para caulinita;

4) A diferença para 1000 está associada a minerais pesados, partículas opacas e indeterminadas. 


\section{REFERÊNCIAS BIBLIOGRÁFICAS}

AB'SABER, A. Domínios morfoclimáticos e solos do Brasil. In: VICTOR HUGO, A. V.; FONTES, L. E. F.; FONTES, M. P. F. (Ed) O solo nos grandes domínios morfoclimáticos do Brasil e o desenvolvimento sustentado. Viçosa: SBCS/UFV/DPS, 1996. p.1-17.

AHUJA, R. L.; MANCHANDA, M. L.; KHANNA, S. S. The weathering and the stability of the soil minerals in the different geomorphic-soil taxonomy units of the Ghaggar river basin of Haryana and Punjab,India. International Journal of Tropical Agriculture. V. 11, n. 2, p. 118122, 1993.

ALIAS, L. J.; ALBALADEJO, J. Mineralogia y genesis de suelos con horizonte B textural sobre rocas calizas en el sureste de España. Anales de Edafologia y Agrobiologia, v.37, n.7-8, p.647-663, 1978. /Resumo em CAB Abstracts on CD-ROM, 1978/

ALLEN, B. L. ; FANNING, D. S. Composition and soil genesis. In: WILDUNG L. P. et al. Pedogenesis and Soil Taxonomy. I. Concepts and Interactions. Amsterdam, Oxford, New York: Elsevier, 1983. p. 141192.

ALMEIDA, J. C. Gênese e mineralogia de Brunos Não- Cálcicos Vérticos e Planossolos Solódicos do semi-árido de Pernambuco. In: CONGRESSO 
BRASILEIRO DE CIÊNCIA DO SOLO, 22., Recife, 1989. Resumos. Recife-PE: S.B.C.S., 1989. p. 206-207.

ALVES, A. J. O. ; RIBEIRO, M. R. Caracterização e gênese dos solos de uma topossequência na microrregião da Mata Seca de Pernambuco. Revista Brasileira de Ciência do Solo, v. 19, n.2, p.297-305, maio/agosto, 1995.

ANTONELLO, L. L. Reserva mineral na fração areia dos solos do Estado de Pernambuco. In: CONGRESSO BRASILEIRO DE CIÊNCIA DO SOLO, 22., Recife, 1989. Resumos. Recife-PE: S.B.C.S., 1989. p. 8081.

AOUDJIT, H.; ROBERT, M.; ELSASS, F. et al. Detailed study of smectite genesis in granitic saprolites by analytical electron microscopy. Clay Minerals. V. 30, n. 2, p. 135-147, 1995.

BARBOSA, G. V. ; PINTO, M. N. Geomorfologia da folha S.A. 23 São Luiz e parte da folha S.A. 24 Fortaleza. In: Projeto Radam Levantamento de Recursos Naturais, 3., MME/DNPM, Rio de Janeiro, 1973.

BATISTA, R. B. Solos do semi-árido da Paraiba afetados por sódio: mineralogia e síntese de minerais. Viçosa, 1988. 129 p. Tese (Doutorado) - Universidade Federal de Viçosa.

BERNER, R. A.; SCHOTT, J. Mechanism of pyroxene and amphibole weathering. II. Observations of soil grains. American Journal of Soil Science, v.282, n.8, p.1214-1231, 1982.

BESOAIN, E. Mineralogia de arcillas de suelos. San José, Costa Rica: IICA, $1985,1216 \mathrm{p}$. 
BIRKELAND, P. W. Soils and Geomorphology. Oxford University Press, NewYork, 1984. 372 p.

BISDOM, E. B. A.; STOOPS, G.; DELVIGNE, J. et al. Micromorphology of weathering biotite and its secondary products. Pedologie, v.32, n.2, p.225-252, 1982.

BLAKE, G. R. (Ed) Methods of soil analysis. Madison, American Society of Agronomy Inc., part 1, 1965.

BLANCO, M. del C.; SANCHEZ, L. F. Caracterizacion de las fracciones limo y arcilla en suelos loesicos del suroeste pampeano en Argentina. Turrialba, v.45, n.1-2, p.76-84, 1995.

BOETTINGER, J. L.; SOUTHARD, R. J. Phyllosilicate distribution and origin in aridisols on a granitic pediment, western Mojave Desert. Soil Science Society America Journal, v.59, n.4, p.1189-1198, 1995.

BRASIL. Ministério da Agricultura. Divisão de Pesquisa Pedológica, DNPEA. Levantamento exploratório-reconhecimento de solos do Estado do Ceará. Recife, Convênios MA/DNPEA - SUDENE/DRN, MA/CONTAP/USAID/ETA, 1973. Volumes 1 e 2, 502 p. (Boletim Técnico, 28).

BREWER, R. Fabric and mineral analysis of soils. Willey, New York, N. Y., 1976. $482 \mathrm{p}$.

BRINDLEY, G. W. Identification of clay minerals by X-ray diffraction analysis. In: Nat. Conf. on Clays and Clay Tecnology, 1th. Proceedings. San Francisco, Dep. of Nat. Resources, 1955. p.119-129.

BROWN, G. (Ed.) The x-ray identification and cristal structures of clay minerals. London: Mineralogical Society, 1961.544p. 
BUCKMAN, H. O. ; BRADY, N. C. Natureza e propriedades do solo. Rio de Janeiro: Livraria Freitas Bastos, 1974. 594 p.

BUOL, S. W. ; HOLE, F. D. ; McCRACKEN, R. J. Soil Genesis and Classification. 1. ed. Ames: The Iowa State University, 1973. 360 p. BUOL, S. W. ;YESILSOY, M. S. A genesis study of a mohave sandy loam profile. Soil Science Society America Proceedings, v. 28, p. 254-256, 1964.

CAMARGO, M. N. ;KLANT, E. ; KAUFFMAN, J. H. Classificação de solos usada em levantamentos pedológicos no Brasil. Campinas, Boletim Informativo da Sociedade Brasileira de Ciência do Solo, v. 12, n. 1, p. 11-33, jan./abr. 1987.

CASS, A. \& JOHNSTON, M. A. Physical and clay mineralogical properties of some Natal and Eastern Transvaal soils. South African Journal of Plant and Soil. v. 2, n. 2, p. 79-84, 1985.

CHAPMAN, S. L. \& HORN, M. E. Parent material uniformity and origin of silty soils in Northwest Arkansas based on zirconium-titanium contents. Soil Science Society America Proceedings, v. 32, p. 265-271, 1968.

COSTA, J. N. Caracterização e interpretação para uso agrícola dos principais solos da região de Ribeira do Pombal-Bahia. Viçosa, 1994. 100 p. Dissertação (M.S.) - Universidade Federal de Viçosa.

DEMATTÊ, J. L. I. ; MARCONI, A. ; SPAROVEK, G. et al. Estimativa da evolução do intemperismo mediante ganhos e perdas de íons numa sequência de solos desenvolvidos de diabásio e influenciados pela drenagem em Piracicaba, SP. Revista Brasileira de Ciência do Solo, v. 15, n. 1, p. 69-73, jan/abr. 1991. 
DEMATTÊ, J. L. I. ; MARCONI, A. A Drenagem na mineralogia de solos desenvolvidos de diabásio em Piracicaba-SP. Revista Brasileira de Ciência do Solo, v. 15, n. 1, p. 1-8, jan./abr. 1991.

DEMATTÊ, J. L. I. ; VIDAL TORRADO, P. SPAROVEK, G. Influência da drenagem na morfogênese de solos desenvolvidos de rochas básicas no município de Piracicaba-SP. Revista Brasileira de Ciência do Solo, v.16, n.2, p.241-247, 1992.

DEMATTÊ, J. L. I. Zircônio e titânio da fração areia de solos. Revista Brasileira de Ciência do Solo, v. 2, p. 74-77, 1978.

DREES, L.R. \& WILDING, L. P. Elemental variability within a sampling unit. Soil Science Society America Proceedings, v. 37, p. 82-87, 1973.

DRIESSEN, P. M. ; DUDAL, R. The major soils of the world. Lecture notes on their geography formation, properties and use. Wageningen: Agricultural University Wageningen and Katholieke Universiteit Leuven, $1991.310 \mathrm{p}$.

EMPRESA BRASILEIRA DE PESQUISA AGROPECUÁRIA. Serviço Nacional de Levantamento e Conservação de Solos. Definição e notação de horizontes e camadas do solo. 2. ed. Rio de Janeiro, 1988. 54 p. (Documento, 3).

ESWARAN, H. \& SHOBA, S. A. Scanning microscopy in soil research. In: BULlOCK, P. \& MURPHY, C. P. (ed.) Soil Micromorphology. Academy Publishing, v. 4, 1983. 356 p.

ESWARAN, H. \& SYS, C. Argillic horizon in LAC soils: formation and significance to classification. Pedologie, v. 29, p.175-190, 1979. 
ESWARAN, H. The alteration of plagioclases and augites under differing pedo-environmental conditions. Journal of Soil Science, v.30, n.3, p.547-555, 1979.

FOST, J. E. \& RUST, R. H. Soil genesis study of a lithological discontinuity in glacial drift in western Wisconsin. Soil Science Society America Proceedings, v. 32, p. 393-398, 1968.

GARCI RODRIGUEZ, M. P. ; FORTEZA BONNIN, J. ; GARCIA RODRIGUEZ, A. et al. Estudio de caracterizacion de minerales (fraccion arena) en suelos gleicos de una zona semiarida. Anales de Edafologia y Agrobiologia, v.47, n.7-8, p.1091-1102, 1988. /Resumo em CAB Abstracts on CD-rom, 1987- 89/

GEBHARDT, H. ; MEYER, B. ; SCHEFFER, F. Mineralogische schnelluntersuchung der grobton schluff und fein sandfraktionen von boden mit dem phasenkontrastmikroskop. Zeiss-mitteil, v. 4, p. 309$322,1967$.

GEBHARDT, H. Mineralogy and genesis of soils in semiarid regions of northeastern Brazil - The amounts of clay formation and clay translocation in Alfisols. Deutschen Bodenkundlichen Gesellschaft. p. 3-10, sept. 1989.

GÓIS, D. V. Gênese de uma sequência de solos em zona semi-árida, município de Valente-Bahia. In: CONGRESSO BRASILEIRO DE CIÊNCIA DO SOLO, 25., Viçosa, 1995. Resumos expandidos. ViçosaMG: S.B.C.S./U.F.V., 1995. p. 1552-1554.

GOLDICH, S. S. A study in rock-weathering. Journal Geology. V. 46, p. 17-58, 1938. 
GOMES, E. C. B. ; MOREIRA, E. G. S. Estudo da natureza e origem de sais em solos afetados por sódio na região de Morada Nova-Ceará. In: CONGRESSO BRASILEIRO DE CIÊNCIA DO SOLO, 25., Viçosa, 1995. Resumos expandidos. Viçosa-MG: S.B.C.S./U.F.V., 1995. p. 1707-1708.

GOMES, M. A. F. \& PINTO, O. C. B. Influência da estrutura de rochas anfibolíticas na gênese de minerais secundários. Revista Ceres. V. 39, n. 221, p.1-12, 1992.

ISBELL, R. F. The argillic horizon concepts and its application to the classification of tropical soils. In: Proceedings conference on classification of tropical soils. Kuala Lumpu: Revista Malasyan Society of Soil Science. p. 150-157, 1980.

JACKSON, M. L. ; SHERMAN, G. D. Chemical weathering of minerals in soils. Advance Agronomy, v. 5, p. 219-318, 1953.

JACKSON, M. L. ; TYLER, S. A. ; WILLIS, A. L. et al. Weathering sequence of clay-size minerals in soils and sediments. Journal Physical Colloid Chemistry, v. 52, p. 1237-1260, 1948.

JACKSON, M. L. Soil chemical analysis. Advanced course. 2. ed. Madison: Un. of Wisconsin, 1969, 895 p.

JACOMINE, P. K. T. Solos sob caatingas - características e uso agrícola. In: VICTOR HUGO, A. V.; FONTES, L. E. F.; FONTES, M. P. F. (Ed) O solo nos grandes domínios morfoclimáticos do Brasil e o desenvolvimento sustentado. Viçosa: SBCS/UFV/DPS, 1996. p.95111. 
JOHN,W. D. ; GRIM, R. E. ; BRADLEY, W. F. Quantitative estimation of clay minerals by diffraction methods. Journal Sedimentary Petrology, v. 24, n.4, p. 242-251, Dec. 1954.

KELLER, W. D.; BALASUBRAMANIAM, K. S. Scanning electron micrographs of clay minerals formed by weathering and other genetic processes. In: Weathering its products and deposits, v.I, Processes. Athens: Theophrastus Publications, 1989. 462p.

KILMER, V. J. ; ALEXANDER, L. T. Methods of making mechanical analyses of soils. Soil Science, v. 68, n. 1, p. 15-24, 1949.

KLAGES, M. G. ; SOUTHARD, A. R. Weathering of montmorillonite during formation of a solodic soil and associated soils. Soil Science v. 106, p. 363-368, 1968.

KLAGES, M. G. Effect of clay typic and exchangeable cations on aggregation and permeability of solonetz soils. Soil Science v. 102, p. 46-52, 1966.

KOPPI, A. J.; WILLIAMS, D. J. Weathering and development of two contrasting soils formed from granodiorite in south-east Queensland. Australian Journal of Soil Research, v.18, n.3, p.257-271, 1980.

LEMOS, R. C. ; SANTOS ,R. D. Manual de descrição e coleta do solo no campo. Campinas: S.B.C.S./S.N.L.C.S., 1984. 46 p.

LUZ, L. R. Q. P. da ; SANTOS, M. C .D. ; MERMUT, A. R. Pedogênese em uma topossequência do semi-árido de Pernambuco. Revista Brasileira de Ciência do Solo, v. 16, n. 1, p. 95-102, jan./abr. 1992. 
Mac EWAN, D. M. C. A trioctahedral montmorillonite derived from biotite. In: INTERN. GEOL. CONGR. GREAT BRITAIN, 18., London, 1948. Abstracts. London: 1948. p. 128.

MARSHALL, C. E. The physical chemistry and mineralogy of soils. I: Soil materials. New York: John Wiley, 1964. 388 p.

McNEAL, B. L. ; SANSOTERRA, T. Mineralogical examination of arid land soils. Soil Science v. 97, p. 367-375, 1964.

MEHRA, O. P. ; JACKSON, M. L. Removal of free iron oxides from soils of clay by sodium dithionite-citrate-bicarbonate method. In: JACKSON, M. L., Soil chemical analysis. Advanced course. 2. ed. Madison, Un. of Wisconsin. 1969. 895 p.

MELFI, A. J.; CERRI, C. C.; KRONBERG, B. I. et al. Granitic weathering: a Brazilian study. Journal of Soil Science, v.34, n.4, p.841-851, 1983.

MELO, A. A. O. de. Características mineralógicas das frações argila e silte fino de solos do município de Uruçuca - BA. Theobroma, v.10, n.3, p.157-165, 1980.

MELO, V. F. ; COSTA, L. M. ; BARROS, N. F. et al. Reserva mineral e caracterização mineralógica de alguns solos do Rio Grande do Sul. Revista Brasileira de Ciência do Solo, v. 19 n. 2, p. 159-164, maio/agosto, 1995.

MiKlos, A. A. W.; TElles, E. C. C. de; MARIANO,B. H. B. et al. Contribuições da microscopia eletrônica de varredura no estudo da gênese de argilo-minerais. In: Congresso Latino Americano de Ciência do Solo, 13., Águas de Lindóia, 1996. Solo-suelo 96: trabalhos. Piracicaba: SBCS/SLCS, 1996. 
MOHR, E. C. J. ; VAN BAREN, F. A. Tropical Soils. New York: Interscience Publishers, Inc. 1959.

MONIZ, A. C. (coord.) ; MEDINA, H. P. ; ORTOLANI, A. A. et al. Elementos de Pedologia. 1. ed. Rio de Janeiro: Livros Técnicos e Científicos Editora S.A, 1975. 459 p.

MONIZ, A. C. ; JACKSON, M. L. Quantitative mineralogical analysis of

Brazilian soils derived from basic rocks and slate. Madison, Wisconsin, Soil Sci. Dep., 1967. 74 p. (Report 212).

MONIZ, A. C. ; OLIVEIRA, J. B. ; CURI, N. Mineralogia da fração argila de rochas sedimentares e de solos da folha de Piracicaba, SP. Revista Brasileira de Ciência do Solo, v.19, p.375-385, 1995.

MONIZ, A. C. Decomposição de rochas e formação de minerais de argila. In: MONIZ, A. C. (coord.) Elementos de Pedologia. 2. ed. Rio de Janeiro: Livros Técnicos e Científicos Editora S.A., 1975. p. 305-323.

MONIZ, A. C. Evolução de conceitos no estudo da gênese de solos. Revista Brasileira de Ciência do Solo, v.20, p.349-362, 1996.

MORERA, E. G. S. Caracterização e gênese de três pedons de Solonetz Solodizado do sertão central e médio Jaguaribe - Estado do Ceará. Piracicaba, 1979. 83 p. Tese (Doutorado) - Escola Superior de Agricultura "Luiz de Queiroz", Universidade de São Paulo.

NETTLETON, W. D. \& PETERSON, F. F. Aridisols, In: WILDING, L. P. et al. Pedogenesis and soil taxonomy, II. The soil orders. Elsevier Science Publishers. New York, N. Y., 1983. P. 165-215. 
NETTLETON, W. D. ; FLACK, K. W. ; BRASHER, B. R. Argillic horizons without clay skins. Soil Science Society America Proceedings, v. 33, p. 121-125, 1969.

NOVIKOFF, A.; TSAWLOSSOU,G.; GAC, J. Y. et al. Weathering of biotites in temperate tropical and equatorial countries. Sciences Geologiques, v.25, n.4, p.287-306, 1972.

OJANUGA, A. G. Weathering of biotite in soils of a humid tropical climate. Soil Science Society America Proceedings v. 37, p. 644-646, 1973.

OLIVEIRA, J. B. DE \& Van den BERG, M. Relations between the soils units of the FAO-UNESCO soil map of the world legend and the soil classes used in brazilian surveys. International Soil Reference and Information Centre. Technical paper 29. Wageningen, The Neterlands, 1996. $57 \mathrm{p}$.

OLIVEIRA, J. B. de ; JACOMINE, P. K. T. ; CAMARGO, M. N. Classes gerais de solos do Brasil: guia auxiliar para seu reconhecimento. Jaboticabal: Funep, 1992. 201 p.

OLIVEIRA, L. B. Análise mecânica em solos da zona semi-árida do Nordeste. Solos: normais, calcários, calcários com sais solúveis e salinos. Pesquisa Agropecuária Brasileira, v. 1, p. 7-15, 1966.

PRADO, H. do. Manual de Classificação de solos do Brasil. Jaboticabal, FUNEP, 1993. 218p.

RABENHORST, M. C. \& WILDING, L. P. Pedogenesis on the Edwards Plateau, Texas: Nature and continuity of parent material. Soil Science Society America Journal v. 50, p. 678-687, 1986. 
RACHID, B.; NATER, E. A.; BLOOM, P. R. et al. Characterization of the weathering status of feldspar minerals in sandy soils of Minnesota using SEM and EDX. Geoderma, v.66, n.1-2, p.137-149, 1995.

RAO, T. V.; RAO, K. P. C.; KRISHNA, M. G . S. R. The nature of soil kaolinites of southern India. Clay Research. V. 4, n. 1, p. 31-37, 1985. REBERTUS, R.A.; WEED, S. B.; BUOL, S. W. Transformations of biotita to kaolinite during saprolite - soil weathering. Soil Science Society America Journal, v. 50, p. 810-819, 1986.

RIBEIRO, L. P. ; SANTOS, D. M. B. ; LIMA NETO, I. de A. et al. Levantamento detalhado dos solos, capacidade de uso e classificação de terras para irrigação da Estação de Plasticultura da Universidade Federal da Bahia/Politeno em Cruz das Almas-Bahia. Revista Brasileira de Ciência do Solo, v. 19, n. 1 p. 105-113, jan./abr. 1995.

RIBEIRO, M. R. ; SANTOS, M. C. D. ; FERREIRA, M. da G. de V. X. Caracterização e gênese de Podzólicos Vermelho-Amarelos do Sertão de Pernambuco. Revista Brasileira de Ciência do Solo, v. 15, n. 1, p. 7581, jan/abr. 1991.

RICE, Jr. T. J.; BUOL, S. W.; WEED, S. B. Soil - saprolite profis derived from mafic rocks in the North Carolina piedmont: I. chemical, morphological and mineralogical characteristics and transformations.. Soil Science Society America Journal v. 49, p. 171-178, 1985.

RICHARDS, L. A. ed. Diagnosis and improvement of saline and alkali soil. Washington, D. C.: Agriculture Handbook n. 60. U. S. D. A., 1954. RICHARDS, L. A. Pressure membrane apparatus: Constrution and Agricultural Engineering, v. 28, p. 454-460, 1947. 
RUST, R. H. Alfisols, In: WILDUNG, L. P. et al. Pedogenesis and soil taxonomy, II. The soil orders. Elsevier Science Publishers. New York, N. Y., 1983. p. 253-281.

SANTOS, M. C. D.; ST ARNAUD, R. J.; ANDERSON, D. W. Quantitative evaluation of pedogenic changes in boralfs (Gray Luvisols) of East Central Saskatchewan. Soil Science Society America Journal, v. 50, p. 1014-1019, 1986.

SAXENA, S. C.; SINGH, K. S. Clay mineralogy of semi-arid region soils of Rajasthan. Journal of the Indian Society of Soil Science, v.31, n.1, p.85-93, 1983.

SCHMEHL, W. R. ; JACKSON, M. L. Interstratification of layer silicates in two soils clays. Clays and Clay Minerals. v. 4, p. 423-428, 1956.

SINGER, A. Clay formation in saprolites of igneous rocks under semiarid to arid conditions, Negev, southern Israel. Soil Science, v. 137, n. 5, p. 332-340, may. 1984.

SMITH, B. R. ; BUOL, S. W. Genesis and relative weathering intensity in three semiarid soils. Soil Science Society America Proceedings, v. 32, p. 261-265, 1968.

SOIL SURVEY STAFF. Keys to soil taxonomy, 5th edition, United States Department of Agriculture, Soil Conservation Service. SMSS technical monograph 19. Pocahontas Press Inc. Blacksburg, Virginia, 1992. 541 p. SOUSA, A. R. Caracterização e interpretação de solos Brunos Não-Cálcicos para uso agrícola, no sertão do Pajeú do Estado de Pernambuco. Viçosa, 1986. 77 p. Dissertação (M.S.)- Universidade Federal de Viçosa. 
SOUTHARD, R. J.; SOUTHARD, A. R. Genesis of cambic and argillic horizons in two northern Utah aridisols. Soil Science Society America Journal, v.49, n.1, p.167-171, 1985.

SOUZA, E. A. de ; RIBEIRO, M. R. ; FERREIRA,M. da G. de V. X. Caracterização e gênese de solos do Baixio de Irecê-Bahia. Revista Brasileira de Ciência do Solo, v. 17, n. 1, p. 89-97, jan./abr. 1993.

SOUZA, M. J. N. Contribuição ao estudo das unidades morfo-estruturais do Estado do Ceará. Revista de Geologia, v.1, n.1, p.63-72, 1988.

SOUZA, M. J. N. Geomorfologia do vale do Choró-Ceará. São Paulo, 1975.

212 p. Séries Teses e Monografias n. 17. Instituto de Geografia, Universidade de São Paulo.

STOLT, M. H.; BAKER, J. C.; SIMPSON, T.W. Soil-Landscape relationships in Virginia: I. Soil variability and parent material uniformity. Soil Science Society America Journal, v. 57, p. 414-421, 1993.

SUDOM, M. D. \& ST. ARNAUD, R. J. Use of quartz, zirconium and titanium as indices in pedological studies. Canadian Journal Soil Science, v. 51, p. 385-396, 1971.

THOMPSON, L. M. El suelo y su fertilidad. 3 ed. Barcelona: Editorial Reverté S.A. 1965. 407 p.

TOMAR, K. P.; PODDER, J.; KUMAR, S. Kaolinite-smectite-vermiculite interstratification in Indo-Gangetic alluvial soils of Meenut. Clay Research, v.4, n.1, p.14-23, 1985.

TROGER, W. E. Optische bestimmung der gesteinsbildenden minerale, teile 1 und 2. Schweizerbartsche verlagsbuchhandlung, Stuttgart, 1969. 
VETTORI, L. Métodos de Análise de Solos. Rio de Janeiro: Ministério da Agricultura. Equipe de Pedologia e Fertilidade do Solo. Boletim Técnico, n. $7,1969.24$ p.

VOLKOFF, B.; RIBEIRO, L. P. O ferro em solos vermelhos latossólicos e podzólicos da região de Jequié - BA. Revista Brasileira de Ciência do Solo, v.3, n.3, p.162-168, 1979.

WILDING, L. P.; ODELL, R. T. FEHRENBACHER, J. B. et al. Source and distribution of sodium in solonetzic soils in Illinois. Soil Science Society America Proceedings, v. 27, p. 432-438, 1963.

WILSON, M. J. The weathering of biotite in some Aberdeenshire soils. Mineral Mag. V. 35, p. 1080-1092, 1966. 